\title{
Direito administrativo e gestão pública e direito urbanístico, cidade e alteridade
}

Ana Paula Basso, Edson Ricardo Saleme, José Sérgio da Silva Cristóvam, Mateus Eduardo Siqueira Nunes Bertoncini

(coords.) 



\section{COMITÉ CIENTÍFICO}

\section{SERIE LEFIS}

\section{Coordinación}

Prof. Fernando Galindo Ayuda. Universidad de Zaragoza

Profa. María Pilar Lasala Calleja. Universidad de Zaragoza

Consejo asesor

Prof. Javier García Marco. Universidad de Zaragoza

Prof. Alejando González-Varas Ibáñez. Universidad de Zaragoza

Prof. Philip Leith. Universidad Queen's de Belfast

Prof. Emérito Abdul Paliwala. Universidad de Warwick

Prof. Aires Rover. Universidad Federal de Santa Catarina

Prof. Erich Schweighofer. Universidad de Viena

Prof. Ahti Saarenpää. Universidad de Rovaniemi 
DIREITO ADMINISTRATIVO E GESTÃO PÚBLICA

E DIREITO URBANÍSTICO, CIDADE E ALTERIDADE 



\title{
DIREITO ADMINISTRATIVO E GESTÃO PÚBLICA E DIREITO URBANÍSTICO, CIDADE E ALTERIDADE
}

\author{
Ana Paula Basso, Edson Ricardo Saleme, \\ José Sérgio da Silva Cristóvam, \\ Mateus Eduardo Siqueira Nunes Bertoncini \\ (coords.)
}


DIREITO administrativo e gestão pública e Direito urbanístico, cidade e alteridade [Recurso electrónico] / Ana Paula Basso... [et al.] (coords.). — Zaragoza : Prensas de la Universidad de Zaragoza, 2019

281 p. ; $22 \mathrm{~cm}$. - (LEFIS series ; 19)

ISBN 978-84-17633-53-0

1. Informática-Derecho-Brasil. 2. Internet en la administración pública. 3. Derecho urbanístico-Brasil

BASSO, Ana Paula

34(81):004

004.738.5:35

004.738:349.44(81)

Cualquier forma de reproducción, distribución, comunicación pública o transformación de esta obra solo puede ser realizada con la autorización de sus titulares, salvo excepción prevista por la ley. Diríjase a CEDRO (Centro Español de Derechos Reprográficos, www.cedro.org) si necesita fotocopiar o escanear algún fragmento de esta obra.

(C) LEFIS

(C) CONPEDI, Conselho Nacional de Pesquisa e Pós-Graduação em Direito Brasil.

(C) De la presente edición, Prensas de la Universidad de Zaragoza (Vicerrectorado de Cultura y Proyección Social)

$1 .^{a}$ edición, 2019

El Centro Universitário de João Pessoa - PB - UNIPÊ ha subvencionado parcialmente la edición de este libro.

Prensas de la Universidad de Zaragoza. Edificio de Ciencias Geológicas, c/ Pedro Cerbuna, 12. 50009 Zaragoza, España. Tel.: 976761 330. Fax: 976761063

puz@unizar.es http://puz.unizar.es

https://www.conpedi.org.br/

Esta editorial es miembro de la UNE, lo que garantiza la difusión y comercialización de sus publicaciones a nivel nacional e internacional. 


\section{SUMÁRIO}

\section{DIREITO ADMINISTRATIVO E GESTÃo PÚBLICA}

APRESENTAÇÃO

José Sérgio da Silva Cristóvam, Mateus Eduardo Siqueira Nunes Bertoncini.

A ADMINISTRAÇÃO DA JUSTIÇA BRASILEIRA E O PRINCÍPIO DA EFICIÊNCIA: UMA REFLEXÃO SOBRE SEUS INDICADORES

Ana Elizabeth Neirão Reymão, Ana Amelia Barros Miranda.

A DISCRICIONARIEDADE ADMINISTRATIVA E A QUESTÃO DA RESPOSTA ADEQUADA NA FISCALIZAÇÃO TRIBUTÁRIA: UMA ANÁLISE A PARTIR DA CRÍTICA HERMENÊUTICA DO DIREITO.

Flávio Couto Bernardes, Gabriel Senra da Cunha Pereira.

A EFETIVIDADE DA GARANTIA DE EFICIÊNCIA NO CONTROLE DE ATOS DOS CARTÓRIOS DO PODER JUDICIÁRIO CATARINENSE.

Tatiana Bettiol Carneiro.

A INTERSETORIALIDADE E A TRANSVERSALIDADE DO DIREITO À SAÚDE .71 Adriano Tacca, Barbara Bedin.

ANÁLISE DA RESPONSABILIDADE CIVIL DO ESTADO POR OMISSÃO: ESTUDO DE CASO SOBRE A ACIDENTALIDADE PROVOCADA PELO ROMPIMENTO DA BARRAGEM EM MARIANA/MG.

Renata Martins de Souza, Edimur Ferreira de Faria.

DA POSSIBILIDADE DE A ADMINISTRAÇÃO PÚBLICA RESOLVER POR CONTA PRÓPRIA PROBLEMAS DE INCONSTITUCIONALIDADE DAS LEIS .114 Maren Guimarães Taborda, Guilherme Oliveira Weber.

DISCUSSÕES SOBRE A CONFORMIDADE CONSTITUCIONAL DA LEI BRASILEIRA DE PARCERIA PÚBLICO-PRIVADA.

Mateus Eduardo Siqueira Nunes Bertoncini, Vinícius Rafael Presente.

ELEMENTOS PARA A PRÁTICA DE ADVOCACIA PREVENTIVA NO ÂMBITO DA

ADVOCACIA-GERAL DA UNIÃO.

Juliano Scherner Rossi, Viviane Regina da Silva.

NOVAS FORMAS DE PACTUAÇÃO NOS CONTRATOS PÚBLICOS E A NECESSIDADE DE PROTEÇÃO DO USUÁRIO DE SERVIÇO PÚBLICO.

Anna Dolores Barros de Oliveira Sá, Alberto Jonathas Maia De Lima.

O CAMINHO DO ALARGAMENTO DAS DISPENSAS DE LICITAÇÃO NO BRASIL: AS CONTRATAÇÕES DE PEQUENO VALOR E EMERGÊNCIA EM UMA ANÁLISE BRASIL - ESPANHA

Felipe Boselli, Carlos Araújo Leonetti. 
SOBRE A DESCONSIDERAÇÃO DA PERSONALIDADE JURÍDICA NO ÂMBITO DA LEI No $12.846 / 13$.

José Sérgio da Silva Cristóvam, Gustavo Costa Ferreira.

\section{DIREITO URBANÍSTICO, CIDADE E ALTERIDADE}

APRESENTAÇÃO

Edson Ricardo Saleme, Ana Paula Basso.

NOVA PERSPECTIVA DA HERMENÊUTICA JURÍDICA NA

INSTRUMENTALIZAÇÃO DA PROTEÇÃO DAS ÁREAS DE PRESERVAÇÃO PERMANENTE DOS ESPAÇOS URBANOS

Zedequias de Oliveira Júnior

OS NÚCLEOS URBANOS INFORMAIS CONSOLIDADOS COMO PRODUTO DA DUPLA CONTINGÊNCIA JURÍDICA NAS CIDADES BRASILEIRAS. .263

Pedro Dias de Araújo Júnior 


\section{DIREITO ADMINISTRATIVO E GESTÃo PÚBLICA ${ }^{1}$}

\section{APRESENTAÇÃO}

O VIII Encontro Internacional do CONPEDI, ocorrido entre os dias 06 e 08 de setembro de 2018, na milenar, histórica e mui acolhedora Zaragoza (Espanha), ofereceu aos seus participantes conferências, painéis e grupos de trabalho de destacada qualidade, como é exemplo o Grupo de Trabalho "Direito Administrativo e Gestão Pública I", que reuniu um qualificado e plural grupo de pesquisadores de todas as regiões do Brasil e da Espanha, marcado por trabalhos de destacada pertinência acadêmica e induvidosa relevância prática.

O traço comum aos artigos apresentados pode ser sintetizado no invulgar apuro intelectual, com comunicados científicos e discussões de sensível qualidade, sobre as mais diversas temáticas do Direito Administrativo, de forma a envolver alunos de mestrado e doutorado, professores e profissionais, com contribuições e discussões marcadas pela forma respeitosa e sob o signo de uma perspectiva dialógica horizontal, democrática, aberta e plural.

Os artigos aqui publicados gravitam em torno das seguintes temáticas:

1. A ADMINISTRAÇÃO DA JUSTIÇA BRASILEIRA E O PRINCÍPIO DA EFICIÊNCIA: UMA REFLEXÃO SOBRE SEUS INDICADORES;

2. A DISCRICIONARIEDADE ADMINISTRATIVA E A QUESTÃO DA RESPOSTA ADEQUADA NA FISCALIZAÇÃO TRIBUTÁRIA: UMA ANÁLISE A PARTIR DA CRÍTICA HERMENÊUTICA DO DIREITO;

3. A EFETIVIDADE DA GARANTIA DE EFICIÊNCIA NO CONTROLE DE ATOS DOS CARTÓRIOS DO PODER JUDICIÁRIO CATARINENSE;

\section{A INTERSETORIALIDADE E A TRANSVERSALIDADE DO DIREITO À SAÚDE;}

\footnotetext{
${ }^{1}$ Nota Técnica: Os artigos que não constam neste livro foram selecionados para publicação na Plataforma Index Law Journals, - http://indexlaw.org/index.php/conpedireview/index.
} 
5. ANÁLISE DA RESPONSABILIDADE CIVIL DO ESTADO POR OMISSÃO: ESTUDO DE CASO SOBRE A ACIDENTALIDADE PROVOCADA PELO ROMPIMENTO DA BARRAGEM EM MARIANA/MG.

6. DA POSSIBILIDADE DE A ADMINISTRAÇÃO PÚBLICA RESOLVER POR CONTA PRÓPRIA PROBLEMAS DE INCONSTITUCIONALIDADE DAS LEIS;

7. DISCUSSÕES SOBRE A CONFORMIDADE CONSTITUCIONAL DA LEI BRASILEIRA DE PARCERIA PÚBLICO-PRIVADA;

8. ELEMENTOS PARA A PRÁTICA DE ADVOCACIA PREVENTIVA NO ÂMBITO DA ADVOCACIA-GERAL DA UNIÃO;

9. NOVAS FORMAS DE PACTUAÇÃO NOS CONTRATOS PÚBLICOS E A NECESSIDADE DE PROTEÇÃO DO USUÁRIO DE SERVIÇO PÚBLICO;

10. O CAMINHO DO ALARGAMENTO DAS DISPENSAS DE LICITAÇÃO NO BRASIL: AS CONTRATAÇÕES DE PEQUENO VALOR E EMERGÊNCIA EM UMA ANÁLISE BRASIL-ESPANHA;

11. SOBRE A DESCONSIDERAÇÃO DA PERSONALIDADE JURÍDICA NO ÂMBITO DA LEI N ${ }^{\circ} 12.846 / 13$;

Um riquíssimo conjunto de temáticas, que mostra a interdisciplinaridade e contemporaneidade das discussões ligadas à atividade administrativa e à gestão pública, inclusive a indicar rumos para a pesquisa e o debate sobre os grandes temas do Direito Administrativo na atualidade.

De nossa parte, estamos profundamente honrados pela Coordenação desse relevante Grupo de Trabalho (GT), com o registro da satisfação em podermos debater com todos os autores e demais participantes.

Por fim, registramos os cumprimentos ao CONPEDI, pela já costumeira qualidade dos encontros, e agradecemos aos colegas da Universidade de Zaragoza (Espanha) pela acolhida 
que tivemos na UNIZAR - nesse relevante momento de divulgação da pesquisa científica na área do Direito. Uma cultura, culinária, história milenar e hospitalidade que conquistaram a todos nós!

Esperamos que os leitores apreciem essa coletânea e suas qualificadas temáticas!

Zaragoza, setembro de 2018.

Coordenadores do GT:

Prof. Dr. José Sérgio da Silva Cristóvam - Universidade Federal de Santa Catarina (UFSC)

Prof. Dr. Mateus Eduardo Siqueira Nunes Bertoncini - Programa de Mestrado em Direito da UNICURITIBA 


\title{
A ADMINISTRAÇÃO DA JUSTIÇA BRASILEIRA E O PRINCÍPIO DA EFICIÊNCIA: UMA REFLEXÃO SOBRE SEUS INDICADORES
}

\author{
Ana Elizabeth Neirão Reymão \\ Centro Universitário do Estado do Pará (PPGD-Cesupa) \\ e Universidade Federal do Pará (FACECON/ICSA/UFPA)
}

Ana Amélia Barros Miranda

Centro Universitário do Estado do Pará (PPGD-Cesupa)

\begin{abstract}
Resumo
O trabalho busca fazer um estudo da prestação da tutela judicial sob a ótica dos princípios da eficiência e da celeridade processual, analisando indicadores e dados divulgados pelo Conselho Nacional de Justiça (CNJ) sobre a atuação do Poder Judiciário. A pesquisa é exploratória, de abordagem qualitativa e quantitativa, especialmente quanto aos indicadores de eficiência da justiça brasileira. Conclui-se que, apesar dos avanços em termos da maior transparência e em favor da eficiência do serviço por ela prestado, essa evolução positiva deve ser relativizada.
\end{abstract}

Palavras-chave: eficiência, Estado, judiciário, morosidade, CNJ.

\section{Abstract/Resumen/Résumé}

This paper aims study of the provision of judicial protection from the perspective of the principles of efficiency and promptness, analyzing indicators and data released by the National Council of Justice (CNJ) on the work of the judiciary. The research is exploratory, with a qualitative and quantitative approach, especially regarding the efficiency indicators of the Brazilian justice system. It is concluded that, despite advances in terms of transparency and in favor of efficient service provided by it, this positive evolution should be qualified.

Keywords/Palabras-claves/Mots-clés: efficiency, State, judiciary, slowness, CNJ. 


\section{Introdução}

O objetivo deste artigo é fazer um estudo da prestação da tutela judicial sob a ótica dos princípios da eficiência e da celeridade processual, analisando, ao final, indicadores e dados colhidos junto ao Conselho Nacional de Justiça (CNJ) e que revelam a atuação do Poder Judiciário como distribuidor de justiça.

A morosidade dessa prestação jurisdicional, por muito tempo, tem sido tema de debate nacional. Não raro são identificadas situações em que a mesma é entregue ao cidadão, mas já não lhe serve mais, posto que tardia.

Tal morosidade frustra a concretização dos direitos dos cidadãos, promove $\mathrm{o}$ descrédito e reduz a confiança no Poder Judiciário que, aos olhos dos jurisdicionados, encontrase incapaz de solucionar conflitos em tempo hábil e de forma efetiva.

Com a edição das Emendas Constitucionais no 19/1998 e 45/2004, pretendeu o Constituinte alçar à condição de constitucional a exigência de atuação do Poder Público, como um todo, com base em critérios de celeridade, eficiência e efetividade, em especial o Poder Judiciário, detentor do monopólio da distribuição de justiça, a fim de que voltasse a ter a confiança da coletividade como instrumento de pacificação social.

Partindo da conceituação do princípio da eficiência, o presente trabalho tem como problema de pesquisa o questionamento acerca da validade dos indicadores de eficiência apresentados pelo CNJ no Justiça em Números. Por validade entende-se a propriedade de um indicador medir ou dar conta do conteúdo normativo do atributo ao qual ele se refere.

Argumenta-se que não basta a elevação à condição de constitucional do preceito da eficiência, mas sim a necessária adaptação da Administração Pública brasileira, aplicável o mesmo ao Poder Judiciário, de mecanismos gerenciais que busquem alcançar e satisfazer os direitos dos cidadãos, produzindo indicadores coerentes com esse objetivo.

A pesquisa é exploratória, de abordagem qualitativa dos mencionados princípios e quantitativa, no que tange aos indicadores da eficiência da justiça brasileira. Como procedimentos, usou-se o levantamento bibliográfico e a consulta a documentos, notadamente os Relatórios Justiça em Números, do CNJ.

O texto inicia com uma breve discussão acerca da crise do Estado, da ruptura com o modelo burocrático de gestão e da emergência do modelo gerencial. Em seguida, analisa-se os princípios da eficiência e da celeridade processual. A crise do Judiciário é tema da próxima seção. O CNJ e a eficiência do judiciário brasileiro encerram as partes principais do texto, antes das considerações finais. 


\section{A crise do Estado, a ruptura com o modelo burocrático de gestão e a emergência do modelo gerencial}

A crítica de que a "mão invisível"1 do mercado, defendida por autores como Adam Smith e outros liberais, não era capaz de resolver os problemas dos desequilíbrios econômicos, as crises e o desemprego crescente, marcado pela Grande Depressão dos anos 1930, levaram ao crescimento do Estado social. Como consequência, passou-se a dele demandar uma atitude participativa nas relações econômicas e na sociedade.

Influenciado pelas propostas de economista John Maynard Keynes, o Estado social assumiu papel de agente regulador, fomentador, empresário, entre outros. Para se adequar ao exercício de tantas funções, a atividade estatal precisou se adequar e, diante do aumento dos conflitos, cresceu também a demanda judicial.

Nesse contexto, não demorou para que fossem pautados problemas como a morosidade e o alto custo do funcionamento do Estado e, de particular interesse para esse artigo, do judiciário.

Muitas foram as críticas no final do século XX quanto à ineficiência do Estado na adequada prestação de serviços de saúde, segurança, educação, cultura e infraestrutura, em um contexto de crise financeira e de demandas sociais crescentes.

Para o enfrentamento dessa "crise do Estado social", o discurso incluía a necessidade de transferência de várias de suas atribuições para a iniciativa privada, devendo aquele assumir apenas o papel de provedor de serviços mínimos como a justiça, a diplomacia e a arrecadação. Ganhou espaço o modelo vinculado ao conservadorismo neoclássico/neoliberal, o chamado modelo gerencial:

O gerencialismo surgiu como resposta ao que se proclamou como 'ineficiência intrínseca do Estado', mediada por um contexto de demandas sociais crescentes e de crise financeira sistêmica, situações que superavam a capacidade do ente em promover soluções de política pública capazes de, ao mesmo tempo, serem eficientes diante das restrições orçamentárias e eficazes em atender os sujeitos sociais, os quais contavam com cada vez mais direitos (REIS, 2015, p. 311).

\footnotetext{
${ }^{1}$ Adam Smith introduziu esse termo no livro "Uma investigação sobre a natureza e as causas da riqueza das nações", conhecido simplesmente como "A Riqueza das Nações”, publicada originalmente em Londres (1776). A metáfora foi utilizada para descrever como, mesmo em uma economia de mercado e sem uma entidade social central para coordenar os interesses comuns, a relação entre os indivíduos resultaria em certa ordem, de modo que a lei da oferta e procura regularia as ações, com mínima interferência do Estado.
} 
Calhao (2007) explica que, diante desse cenário, os Estados nacionais começaram a adotar uma nova forma de política, em que o desenvolvimento social e econômico passou a ter papel subsidiário, transferindo-se para a iniciativa privada essa responsabilidade. $\mathrm{O}$ poder público assumiu um papel supletivo às funções típicas de mercado, que antes ficavam ao seu encargo, aproximando-se de uma lógica de Estado mínimo, argumenta o autor.

O modelo burocrático, até então vigente, enfatizava que as atividades administrativas deviam ser coordenadas pela integral obediência aos preceitos legais. Sua principal característica, explicam Gonçalves e Souza (2014), era o regramento inflexível das atividades do Estado, gerando um engessamento dos agentes públicos. Ou seja, a burocracia e a dominação racional faziam com que as atividades do cotidiano fossem disciplinadas pela legislação. As formalidades seriam exageradas, com rotinas e procedimentos rigorosos sendo utilizados nas prestações de serviços. Em consequência, ter-se-ia uma lentidão e ineficiência quanto ao alcance da finalidade pretendida pelo ente público (GONÇALVES; SOUZA, 2014).

O modelo gerencial emergiu do discurso de que se fazia necessária a redução de custos, a definição de prioridades de maneira democrática, de cobrança de resultados e do alcance de maior articulação com a sociedade. Com ele, a administração pública anunciava a incorporação de valores e práticas do mercado privado, prezando-se os resultados positivos e ficando o procedimento em segundo plano.

Nesse contexto, a obediência aos procedimentos pré-determinados para se verificar a moralidade do funcionário do modelo burocrática foi substituída por uma verificação sobre a obtenção do resultado, esclarecem Gonçalves e Souza (2014).

A reforma administrativa e uma administração de resultados ganharam espaço. Defendia-se uma administração em que os agentes públicos teriam maior liberdade na execução das tarefas, sendo controlados por meio dos resultados alcançados. Para tal, prometia-se um novo tipo de servidor público mais qualificado, profissionalizado, produtivo e eficiente, bem como a prestação de serviços de maior qualidade para a população (MORAIS, 2014).

A privatização de empresas estatais e a terceirização, sob a justificativa de que o Estado não possuía as condições e os recursos suficientes para prestar os serviços à população, acompanharam a implantação desse modelo gerencial.

Dentre suas características, Bresser Pereira (2001) destaca a descentralização política, com transferência de recursos e atribuições para os níveis regionais locais; descentralização administrativa, com delegação de autoridade aos administradores públicos; gerentes cada vez mais autônomos; organizações com poucos níveis hierárquicos; pressuposto da confiança limitada na confiança e não da desconfiança total; controle a posterior, ao invés do controle 
rígido dos processos administrativos; e, finalmente, uma administração voltada ao atendimento do cidadão.

Essas mudanças, vale ressaltar, não ocorreram apenas no Brasil, mas sim parte de uma onda que atingiu outros Estados contemporâneos. No caso brasileiro, a Emenda Constitucional $n^{\text {o }} 19$, de 4 de junho de 1998, trouxe à CF/88 muitas modificações significativas, e introduziu uma reforma administrativa para "reorganizar" o Estado em favor de uma administração pública que incorporasse o modelo gerencial. A Emenda Constitucional $\mathrm{n}^{\mathrm{o}} 45$, de 08 de dezembro de 2004, por sua vez, inseriu o princípio da celeridade processual, como discute a seção a seguir.

\section{Os princípios da eficiência e da celeridade processual: questionamentos acerca da satisfação dos direitos dos jurisdicionados}

A crescente consciência dos direitos sociais e individuais pelo cidadão somado a um conjunto de frustrações de toda a sociedade fizeram com que a eficiência da Administração Pública passasse a ser ponto central de discussão e de questionamentos acerca da implementação de uma política jurisdicional de qualidade.

Analisando a atividade jurisdicional brasileira, objeto do presente estudo, observa-se o clamor da sociedade em exigi-la desempenhada com eficiência e com atendimento real dos direitos tutelados.

Os princípios da eficiência e da razoável duração do processo, ambos de natureza constitucional e aplicáveis ao Poder Judiciário, são elementos imperativos na busca pela qualidade na prestação do serviço à coletividade.

Na lição clássica de Barroso (1999, p. 147), princípios são:

[ ] as normas eleitas pelo constituinte como fundamentos ou qualificações essenciais da ordem jurídica que institui. A atividade de interpretação da constituição deve começar pela identificação do princípio maior que rege o tema a ser apreciado, descendo do mais genérico ao mais específico, até chegar à formulação da regra concreta que vai reger a espécie [...] Em toda ordem jurídica existem valores superiores e diretrizes fundamentais que 'costuram' suas diferentes partes. Os princípios constitucionais consubstanciam as premissas básicas de uma dada ordem jurídica, irradiando-se por todo o sistema. Eles indicam o ponto de partida e os caminhos a serem percorridos.

Inicialmente nomeado no esboço que deu origem à Emenda Constitucional no 19/98 como "princípio da qualidade do serviço prestado", o princípio da eficiência foi considerado como resultado do descontentamento da sociedade da época, em face da reconhecida 
impotência na luta contra a deficiente prestação dos serviços públicos e os incalculáveis prejuízos até então acarretados à coletividade em geral (GABARDO, 2002, p. 20).

No entanto, com a inclusão do postulado no caput do artigo 37 da Constituição Federal, tal conceituação não vingou, tendo prevalecido o conceito genérico de "qualidade total", característica da iniciativa privada, e que recebeu inúmeras críticas por parte da Doutrina.

A eficiência deve ser entendida não apenas como um preceito constitucional, mas como uma exigência inerente à toda atividade pública, considerando que a mesma é voltada a servir a coletividade na justa medida de suas necessidades, razão pela qual não se pode admitir uma Administração ineficiente e negligente.

Em que pese tal conclusão, necessário ressaltar a impossibilidade de o administrador público abrir mão da legalidade a fim de alcançar maior eficiência em sua atuação, considerando que, contrariamente aos particulares que tudo podem fazer desde que não haja proibição legal, ao administrador é permitido atuar dentro dos limites permitidos pela norma legal, face à estrita obediência ao princípio da legalidade.

Referida obediência visa a segurança jurídica da coletividade, também fundamento do Estado de Direito, e impede que o Administrador, sob a argumentação de eficiência, atue em desatendimento à legalidade. Entretanto, é válido ressaltar que tal vedação não autoriza a negligência administrativa.

Amaral (2006, p. 6) bem explica a convivência entre os princípios da legalidade e da eficiência:

\begin{abstract}
A pessoa privada, que age dentro da chamada "autonomia da vontade", não está desobrigada de cumprir a lei. Muito menos a Administração Pública, que deve agir em conformidade com a lei. Adotando a distinção efetuada por André Gonçalves Pereira ("Erro e Ilegalidade no Ato Administrativo", Lisboa, Ática, 1962), entre licitude e legalidade, posso dizer que a atuação do agente administrativo deve ser eficiente e legal. Em outras palavras: dizer-se que a Administração está autorizada a praticar atos ilegais, desde que isso contribua para aumentar sua eficiência, é no mínimo tão absurdo quanto dizer-se que uma empresa privada pode praticar atos ilícitos, desde que isso contribua para aumentar sua eficiência.
\end{abstract}

Sabe-se, porém, que a simples disposição legal da eficiência, na realidade, por si só, não a produz. Necessita a Administração Pública de um moderno sistema de gerenciamento capaz de traduzir o mandamento legal em resultados práticos.

A aplicação do princípio da eficiência na atividade administrativa busca a atuação estatal com base em padrões de condutas que verdadeiramente representem compromisso no atendimento das necessidades da coletividade evitando, inclusive, desperdício de recursos públicos. 
No plano do direito nacional, alguns estudiosos acrescentam à Administração Pública, além da obrigatoriedade de atendimento ao princípio da eficiência, o atendimento ao direito à boa administração.

Freitas (2007, p. 20) apresenta um conceito descritivo do que entende ser seu conteúdo normativo:

\begin{abstract}
Trata-se do direito fundamental à administração pública eficiente e eficaz, proporcional cumpridora de seus deveres, com transparência, motivação, imparcialidade e respeito à moralidade, à participação social e à plena responsabilidade por suas condutas omissivas e comissivas. A tal direito corresponde o dever de a administração pública observar, nas relações administrativas, a cogência da totalidade dos princípios constitucionais que a regem.
\end{abstract}

O reconhecimento do direito à boa administração, seja como um princípio aplicável à Administração Pública ou como direito de cidadania, pode influenciar nas questões referentes ao Poder Judiciário e atendimento eficaz às demandas da sociedade.

Grande controvérsia no Poder Judiciário brasileiro tem sido a constatação do descompasso entre o tempo de duração de um processo até a fase final de execução e a efetiva satisfação da tutela requerida pelo cidadão.

Como tentativa de solução, pretendeu o legislador constituinte, com a Emenda Constitucional $\mathrm{n}^{\mathrm{o}} 45$, de 08 de dezembro de 2004, e a inserção do princípio da celeridade processual, nos moldes previstos no art. $5^{\circ}$, inciso LXXVIII ${ }^{2}$ da Constituição Federal, introduzir o direito fundamental à razoável duração do processo, permitindo a cada cidadão a exigência de sua aplicabilidade no caso concreto.

O processo de duração razoável representa satisfazer o jurisdicionado em seu sentimento de reparação do bem lesado ou na garantia de um direito violado, em tempo razoável, por meio de um processo sem dilações, observando-se que o processo não pode ser considerado um fim em si mesmo, mas sim um instrumento de realização eficaz do direito invocado pelo jurisdicionado.

Segundo Theodoro (2010, p. 20), processo justo é o que se alcança efetividade na prestação da tutela requerida:

\footnotetext{
${ }^{2}$ LXXVIII - a todos, no âmbito judicial e administrativo, são assegurados a razoável duração do processo e os meios que garantam a celeridade de sua tramitação.
} 
[...] é evidente que sem efetividade, no concernente ao resultado processual cotejado com o direito material ofendido, não se pode pensar em processo justo. E não sendo rápida a resposta do juízo para a pacificação do litígio a tutela não se revela efetiva. Ainda que afinal se reconheça e proteja o direito violado, o longo tempo em que o titular, no aguardo do provimento judicial, permaneceu privado de seu bem jurídico, sem razão plausível, somente pode ser visto como uma grande injustiça. Daí por que, sem necessidade de maiores explicações, se compreende que o Estado não pode deixar de combater a morosidade judicial e que, realmente, é um dever primário e fundamental assegurar a todos quantos dependam da tutela da Justiça uma duração razoável para o processo e um emprenho efetivo para garantir a celeridade da respectiva tramitação.

A garantia constitucional concedida ao cidadão engloba não apenas o seu direito de Ação, mas o direito à prestação de uma tutela adequada, eficaz e célere, o que não tem sido a realidade nacional que se encontra muito distante do ideal normativo, como se verá em tópico posterior.

Considerando que o Estado assumiu o monopólio da função jurisdicional e, por isso, garantidor da paz social, o dever de eficiência e de boa administração se estende ao Poder Judiciário. Espera-se que o mesmo proporcione ao jurisdicionado a concretização de seu direito por meio da prestação de uma tutela satisfatória que lhe assegure não apenas o direito de ação, mas a tutela adequada de seu direito, de forma tempestiva e eficaz. Essa, porém, não é uma realidade, como mostra a próxima seção.

\section{A crise do judiciário: algumas interpretações e a pressão social pela eficiência}

A busca pela maior eficiência do Estado no exercício de suas funções também atingiu o Poder Judiciário, pois a administração da justiça não foi capaz de acompanhar e dar uma resposta à sociedade na mesma rapidez que a eclosão de demandas litigiosas.

O dilatamento de áreas em que o judiciário passou a ter ingerência, com a ampliação do catálogo de direitos garantidos aos cidadãos, gerou um crescente número de processos e fatores como a corrupção, a burocracia, a insuficiência de recursos materiais e humanos, a formalidade nos procedimentos, a falta de gestão, dentre outros, desembocaram numa crise no judiciário.

Muitos autores discutem essa questão e argumentam que, apesar de não ser recente, foi acentuada após a promulgação da Constituição Federal de 1988, que teria criado novos direitos civis e novos instrumentos de litígio: 
O estado de crise do Judiciário brasileiro não é recente. Desde meados do século XX, juízes e especialistas assim consideravam a situação das cortes no país. No entanto, há razoável consenso de que a promulgação da Constituição Federal de 1988 — a chamada 'Constituição Cidadã' — acentuou gravemente esta crise (ROSENN, 1998; MOREIRA 2004). A criação de novos direitos civis e novos instrumentos de litígio, a abertura da economia, o estabelecimento da democracia política e a implementação de diversas políticas econômicas inadequadas, até mesmo de constitucionalidades duvidosas, criaram milhares, ou até mesmo milhões, de novos processos judiciais. Claramente, os tribunais não têm sido capazes de responder a todas estas demandas (YEUNG; AZEVEDO, 2012, p. 644).

A imagem de poder em crise do judiciário, então, revela-se por sua incapacidade de responder ao seu papel constitucional, tanto nos conflitos individuais, quanto na prestação de justiça ou mediação e resolução dos conflitos políticos, argumenta Moreira (2004).

Há déficits quantitativos e qualitativos, associados à morosidade na prestação da justiça e à pouca efetividade das decisões judiciais, o que não se traduz em um fator positivo de pacificação social (MOREIRA, 2004).

Para Gico Júnior (2014), a crise decorre de uma sobreutilização desse poder, que ele vê como lento e caro demais. Seu argumento é de que isso gera uma morosidade e que atrapalha o desenvolvimento econômico.

Estudos do final dos anos 1990 mostravam que o elevado número de processos por magistrado e uma taxa de resolução inferior a 90\% resultaram no aumento de estoque de processos acumulados e do volume de trabalho do magistrado médio. Para que os tribunais eliminassem seus casos pendentes e entrantes, São Paulo necessitaria de 2,7 anos e Brasília, de 3 anos, sem nenhum caso novo adicional (DAKOLIAS, 1999 apud GICO JÚNIOR, 2014).

Ao lado desse elevado tempo necessário, porém, o Brasil se destaca pelo elevado número de magistrados. Então, o autor discorda do argumento de que a questão da lentidão judicial seja um problema de oferta, de que há um subinvestimento na produção, distribuição e fornecimento do serviço público adjudicatório. Discorda, assim, dos que afirmam que esse subinvestimento pode decorrer da falta de magistrados ou servidores (recursos humanos), da falta de infraestrutura (capital físico) ou de ambos. Discorda dos que defendem, como solução para o bom funcionamento do judiciário, o maior treinamento de magistrados e servidores despreparados, bem como um maior número de equipamentos e uma melhor infraestrutura. Enfim, para Gico Junior (2014), a solução para a crise do judiciário não está na simples contratação de mais e melhores magistrados e de outros investimentos nesse poder da República. 
Seu argumento é de que parte do insucesso das medidas adotadas para dar mais agilidade a esse Poder está na incompreensão de os formuladores de políticas públicas acerca da natureza de recurso comum do judiciário. Trata-se de um bem rival e, como tal, um bem que quanto maior o seu uso, menos "quantidades" dele ficam disponíveis para outras pessoas usarem. Nas palavras do autor: "quanto mais pessoas utilizarem o judiciário, menos útil ele será para a coletividade, pois menor será sua capacidade de prestar serviços públicos adjudicatórios” (GICO JÚNIOR, 2014, p. 178).

Assim, a escolha social de garantir o acesso irrestrito ao judiciário, cuja característica é de rivalidade, fez emergir um incentivo à sobreutilização dos serviços públicos adjudicatórios e sua decorrente morosidade, defende o autor.

Apesar de reconhecer potenciais outras causas para a referida crise, como a quantidade e a qualidade (ruim) das leis, a inobservância das leis pelo Estado, a cultura de litigância, o elevado número de recursos judiciais e mesmo a escassez de recursos materiais, destaca que os magistrados podem estar contribuindo para essa morosidade: "os magistrados podem ser uma das, se não a principal, causas da morosidade judicial e do aumento persistente dos litígios no país" (GICO JÚNIOR, 2014, p. 193).

Assim, a saída seria uma o investimento em capital jurídico, com uniformização de jurisprudência e fortalecimento da segurança jurídica. Essas deveriam ser, na opinião do autor, o foco de políticas públicas cujo objetivo é ampliar o acesso aos serviços públicos adjudicatórios e a reduzir o número de litígios:

Se a sobreutilização do Judiciário é um resultado trágico do subinvestimento em capital jurídico, a exclusão de litigantes marginais devido à morosidade judicial e a atração de litigantes não titulares de interesses juridicamente protegidos, cujo principal objetivo é justamente postergar suas obrigações (seleção adversa), é um efeito ainda mais trágico desse arranjo institucional. Conquanto esse problema possa ser mitigado adotando-se taxas de juros legais compatíveis com as taxas de mercado, a única medida que efetivamente reduz a utilização do Judiciário, sem excluir usuários (livre acesso) ou sem atrair maus litigantes, é o investimento em capital jurídico (GICO JÚNIOR, 2014, p. 193).

Para Faria (2005), a "crise da Justiça” é evidenciada na ineficiência com que o judiciário desempenha três funções básicas: a instrumental (ser locus de resolução dos conflitos), a política (ser mecanismo de controle social, fazendo cumprir direitos e obrigações) e a simbólica (ao disseminar uma ideia de equidade e justiça na vida social). Porém, o exercício dessas três funções é incompatível, na ótica do autor, com sua arquitetura, concebida para exercê-las em uma sociedade estável, com níveis equitativos de distribuição de renda e um sistema legal integrado por normas padronizadoras, e a realidade socioeconômica brasileira, marcada por uma profunda desigualdade. 
Ou seja, a realidade a partir da qual e sobre a qual tem de atuar é incoerente com esse modelo de judiciário. Ela leva a uma "judicialização" da economia e da política e, em alguns casos, como resposta aos casos que lhes são submetidos, os magistrados sentem-se impelidos decidir ultrapassando os limites da própria ordem legal e, notadamente quando a norma não está clara ou é controvertida, acabam exercendo uma "criatividade decisória" (FARIA, 2005, p. 27).

O judiciário estaria numa encruzilhada pois, de um lado, é acionado pelos “excluídos” para dirimir conflitos relativos à desigualdade e conflitos que a globalização econômica impõe, afetando o processo de apropriação das riquezas e distribuição equitativa dos benefícios sociais. Ou seja, é acionado para que lhes sejam reconhecidos os direitos de cidadania, assegurados pela $\mathrm{CF} / 88$. E se for moroso, prejudicará a população de baixa renda:

Quando os tribunais estão sobrecarregados com funções que não são suas ou se encontram em confronto com os demais poderes, a perda de rapidez, coerência e qualidade em seus serviços se converte em sinônimo de negação de justiça - principalmente para a população de baixa renda (FARIA, 2005, p. $34)$.

Do outro lado, é desprezado por setores "incluídos" na economia mundial, que lhes acusam de impactar negativamente no desempenho das empresas, de não dar a devida proteção legal aos emprestadores do sistema financeiro, de comprometer o crescimento econômico, entre outras críticas:

No sistema econômico, a incapacidade judicial de confirmação de expectativas de direito torna-se fator de disseminação de insegurança no mundo dos negócios e de multiplicação de custos indiretos, com impacto negativo no desempenho das empresas, na proteção legal de créditos e no estabelecimento das providências a serem tomadas no caso da impossibilidade de sua cobrança, na definição das propriedades materiais e intelectuais e na própria qualidade das políticas macroeconômicas (FARIA, 2005, p. 34).

Trata-se de uma missão complexa e impõe grandes desafios para a gestão da política judiciária no país. Esse não é um problema novo. A morosidade e a crise levaram, em 2004, à assinatura do I Pacto pelo Judiciário (2004), tendo como objetivo organizar as instituições públicas em favor de um judiciário mais rápido e republicano. Apesar de sua importância, porém, sua assinatura não foi pautada em dados ou estudos sobre as razões ou causas da crise, traduzindo-se em poucos resultados concretos.

Em 2009, um novo acordo foi celebrado entre os Poderes, II Pacto Republicano de Estado, anunciando também um sistema de justiça mais acessível, ágil e efetivo. O discurso era 
o de fortalecer a proteção aos direitos humanos, dando maior efetividade à prestação jurisdicional, ampliando o acesso à Justiça e buscando o aperfeiçoamento do Estado Democrático de Direito e das instituições judiciárias (PLANALTO, 2009).

O Novo Código de Processo Civil (CPC), que passou a vigorar em 18 de março de 2016, também teve como mote a redução da morosidade judicial, incluindo alguns instrumentos processuais para dar maior celeridade ao processo. Porém, suas novas normas processuais também não foram precedidas de estudos empíricos acerca das causas da morosidade judicial ou sobre os custos decorrentes dos novos arranjos institucionais previstos:

Em outras palavras, foi usado apenas o conhecimento jurídico (que normalmente se limita a senso comum e técnicas hermenêuticas) para discutir as consequências individuais e coletivas das regras por vir. Uma análise custo-benefício que levasse em consideração, de forma expressa, ganhos e perdas associadas a cada mudança não parece ter sido feita (GICO JÚNIOR, 2014, p. 169).

Ou seja, pouco se sabe sobre os tribunais brasileiros, não sendo comum a realização de estudos teóricos ou empíricos mais abrangentes sobre os temas sobre os quais se legislou. A criação do Conselho Nacional de Justiça (CNJ), os indicadores e a análise de eficiência dos tribunais brasileiros que por ele vem sendo elaboradas fugiriam a essa lógica ou representam avanços para uma maior eficiência e realização efetiva de Justiça? É essa questão que a seção seguinte pretende investigar.

\section{O CNJ e a eficiência do judiciário brasileiro}

Criado pela Emenda Constitucional n ${ }^{0}$ 45/04, o Conselho Nacional de Justiça (CNJ) tem participação importante no debate sobre a melhora da eficiência do judiciário brasileiro e na democratização do Poder Judiciário. Para Calhao (2010), sua criação foi importante porque preencheu uma lacuna quanto à existência de um órgão fiscalizador e planificador das ações estruturais do Poder Judiciário.

Nesse espírito, sua proposta é assegurar maior transparência, moralidade, controle e coordenação administrativa. Dentre as atribuições do Conselho, tem-se as de controle e fiscalização de cunho financeiro, administrativo e correcional. Foi criado como órgão central de coordenação e integração dos órgãos jurisdicionais brasileiros, com exceção do Supremo Tribunal Federal (STF), destaca Peluso (2010).

Sediado em Brasília (DF), é formado por quinze membros com mandado de dois anos, admitida uma recondução. É um órgão administrativo e, como tal, não tem autorização para 
intervir no exercício da função jurisdicional, que é prerrogativa de cada tribunal ou juiz, prevista em norma constitucional. Porém, entende Peluso (2010), sua criação foi importante como um instrumento para o aperfeiçoamento do sistema judiciário brasileiro e em favor da concretização do ideal de uma justiça célere e eficiente.

Silveira e Mezzaroba (2011) destacam que o CNJ busca atribuir maior transparência ao Poder Judiciário na administração e na eficiência do serviço prestado, de acordo com os princípios inscritos no caput do art. 37 da $\mathrm{CF} / 88$. Nesse sentido, visa atuar para ampliar as formas de acesso ao Poder Judiciário e aperfeiçoar os serviços jurisdicionais. Dessa maneira, sua atuação deve ser interpretada à luz das modificações estabelecidas pela EC n ${ }^{\circ} 45 / 2004$, principalmente quanto à razoável duração do processo e à celeridade processual.

Pouco depois, foi criado o Sistema de Estatística do Poder Judiciário (2005), hoje Sistema de Estatísticas do Poder Judiciário Nacional (SIESPJ), com o objetivo de concentrar e analisar os dados encaminhados por todos os Tribunais do país. Nesse espírito, o CNJ divulga alguns indicadores, como os resumidos no quadro 1 .

De modo geral, os relatórios Justiça em Números (CNJ) evidenciam uma evolução positiva.

Os processos em tramitação no Poder Judiciário, ou seja, aguardando alguma solução definitiva em 2016, foram de 79,7 milhões. "Desses, 13,1 milhões, ou seja, 16,4\%, estavam suspensos ou sobrestados ou em arquivo provisório, aguardando alguma situação jurídica futura" (CNJ, 2017, p. 65). O estoque de processos cresceu em 2,7 milhões, ficando 3,6\% superior ao ano anterior.

Apesar de tais dados significarem que, se o judiciário parasse de receber ações novas e se dedicasse a julgar apenas os processos em trâmite em fins de 2016, precisaria dedicar dois anos e oito meses à tarefa, observa-se que o texto traz uma visão mais otimista quando comparado ao Justiça em Números de 2013, que afirmava:

O total de processos em tramitação no Poder Judiciário aumenta gradativamente desde o ano de 2009, quando era de 83,4 milhões de processos, até atingir a tramitação de 92,2 milhões de processos em 2012, sendo que, destes, 28,2 milhões (31\%) são casos novos e 64 milhões (69\%) estavam pendentes de anos anteriores. Por outro lado, houve crescimento do total de processos baixados, atingindo-se 27,8 milhões de processos no último ano. Em mais um ano, o número de processos baixados foi inferior ao de casos novos. Isso aponta para uma tendência de que o estoque aumente para o ano de 2013. Em termos relativos, os casos novos são os que mais cresceram, com aumento de $8,4 \%$ no ano, enquanto os baixados tiveram incremento de $7,5 \%$ e as sentenças em 4,7\%. O maior gargalo do judiciário apresenta-se na liquidação do estoque, visto que, inobstante os tribunais terem sentenciado e baixado quantidade de processos em patamares semelhantes ao ingresso de casos novos, o quantitativo de processos pendentes tem se ampliado em função dos aumentos graduais da demanda pelo Poder Judiciário (CNJ, 2013, p. 298-299). 
Quadro 1 - IPC-Jus e outros indicadores da gestão judiciária e litigiosidade da justiça brasileira

\begin{tabular}{|c|c|}
\hline INDICADOR & DETALHAMENTO \\
\hline Carga de Trabalho por Magistrado & $\begin{array}{l}\text { Fornece a média de trabalho que cada } \\
\text { magistrado tinha para lidar durante o ano. } \\
\text { É calculado pela soma dos processos baixados, } \\
\text { dos casos pendentes, dos recursos internos } \\
\text { julgados, dos recursos internos pendentes, dos } \\
\text { incidentes em execução julgados e dos } \\
\text { incidentes em execução pendentes. Em seguida, } \\
\text { divide-se pelo número de magistrados em } \\
\text { atuação. } \\
\text { O CNJ esclarece que, na carga de trabalho, } \\
\text { todos os processos são considerados, inclusive } \\
\text { as execuções judiciais. }\end{array}$ \\
\hline Carga de Trabalho por Servidor & $\begin{array}{l}\text { Mesmo procedimento do indicador anterior, } \\
\text { porém com a divisão pelo número de servidores } \\
\text { da área judiciária. }\end{array}$ \\
\hline IPM (Índice de Produtividade dos Magistrados) & $\begin{array}{l}\text { Computa a média de processos baixados por } \\
\text { magistrado em atuação. }\end{array}$ \\
\hline $\begin{array}{l}\text { IPS-Jud (Índice de Produtividade dos Servidores da Área } \\
\text { Judiciária) }\end{array}$ & $\begin{array}{l}\text { Fornece a média de processos baixados por } \\
\text { servidor da área judiciária. }\end{array}$ \\
\hline IAD (Índice de Atendimento à Demanda) & $\begin{array}{l}\text { Verifica se o tribunal foi capaz de baixar } \\
\text { processos pelo menos em número equivalente } \\
\text { ao quantitativo de casos novos. } \\
\text { O ideal é que esse indicador permaneça } \\
\text { superior a } 100 \% \text { para evitar aumento dos casos } \\
\text { pendentes. }\end{array}$ \\
\hline Taxa de Congestionamento & $\begin{array}{l}\text { Mede o percentual de casos que permaneceram } \\
\text { pendentes de solução ao final do ano-base, em } \\
\text { relação ao que tramitou (soma dos pendentes e } \\
\text { dos baixados). }\end{array}$ \\
\hline IPC-Jus (Índice de Produtividade Comparada) & $\begin{array}{l}\text { Calculado segundo o método DEA (Análise } \\
\text { Envoltória de Dados), considerando os } \\
\text { seguintes inputs (recursos) e outputs } \\
\text { (produtos): } \\
\text { - Inputs: processos que tramitam (= processos } \\
\text { baixados + processos pendentes) + Despesa } \\
\text { total - despesa com pessoal inativo - despesa } \\
\text { com projetos de construção e obras + } \\
\text { Número de magistrados e de servidores } \\
\text { efetivos, requisitados e comissionados sem } \\
\text { vínculos - cedidos para outros órgãos. } \\
\text { - Outputs: processos baixados. }\end{array}$ \\
\hline
\end{tabular}

Fonte: CNJ (2017).

Ou seja, houve um aumento dos processos em tramitação até 2012 (92,2 milhões). É um número bastante superior ao de 2016. Observa-se também que o número de processos baixados vinha crescendo, ainda que em um número inferior ao de casos novos.

Assim, a liquidação do estoque de processos era entendida como o maior gargalo do judiciário, pois apesar de os tribunais terem sentenciado e baixado quantidade de processos em níveis próximos ao ingresso de casos novos em 2012, o número de pendentes vinha se ampliado com os aumentos graduais da demanda pelo Poder Judiciário. 
Em 2016, os casos novos (29,4 milhões) foram (quase) iguais aos de processos baixados, o que representou um crescimento em relação ao ano anterior de 5,6\% e 2,7\%, respectivamente (CNJ, 2017). Em consequência, o Índice de Atendimento à Demanda foi de $100,3 \%$ e, por ser superior a $100 \%$, mostrou que o judiciário foi capaz de baixar processos em número levemente superior ao quantitativo de casos novos.

Observa-se, no entanto, um crescimento do número de casos novos: "Em média, a cada grupo de 100.000 habitantes, 12.907 ingressaram com uma ação judicial no ano de 2016. Neste indicador são computados somente os processos de conhecimento e de execução de títulos extrajudiciais, excluindo, portanto, da base de cálculo, as execuções judiciais iniciadas" (CNJ, 2017, p. 69).

Assim, apesar do aumento do número de processos baixados, entre 2009 e 2016, o crescimento acumulado do estoque de processos foi de $31,2 \%$, ou seja, acréscimo de 18,9 milhões. A Justiça Estadual $(79,2 \%)$ e a Justiça Federal concentram $(12,6 \%)$ a maior parte desses processos pendentes (CNJ, 2017).

Os índices de produtividade dos magistrados (IPM) e dos servidores (IPS-Jud), calculados pela relação entre o volume de casos baixados e o número de magistrados e servidores na jurisdição, respectivamente, como mostrado no Quadro 1 , variaram em $-1,2 \%$ (IPM) e 2\% (IPS-Jud) em 2016, comparado com o ano anterior: "uma média de dois casos a mais baixados por servidor em relação à 2015" (CNJ, 2017, p. 180). Assim, o IPM foi 1749 processos e o IPS-Jud 139 processos, considerando todo o judiciário em 2016.

As cargas de trabalho, que revelam o número de procedimentos pendentes e resolvidos no ano, como mostra o mesmo Quadro, registraram decréscimo para os magistrados $(-0,8 \%)$ e crescimento (2,5\%) para os servidores (CNJ, 2017).

Quanto à taxa de congestionamento do Poder Judiciário, que mede o percentual de processos que ficaram represados sem solução, comparativamente ao total tramitado no período de um ano, os dados mostram que ela se manteve em altos patamares, sempre acima de 70\%, no período de 2009 a 2016. Trata-se de um indicador que não oscila muito: "as variações anuais são sutis e, em 2016, houve aumento de 0,2 ponto percentual. Ao longo de 7 anos, a taxa de congestionamento variou em apenas 2,5 pontos percentuais" (CNJ, 2017, p. 76).

Por fim, destaca-se o IPC-Jus, indicador criado pelo CNJ que resume os dados do judiciário brasileiro uma única medida, visando refletir a produtividade e a eficiência relativa dos tribunais por meio do método DEA (Análise Envoltória de Dados). A análise permite avaliar o desempenho de cada tribunal quanto à geração de outputs (produtos) com os inputs (recursos) disponíveis para, posteriormente, comparar o valor encontrado da relação produto-insumo com 
uma fronteira de eficiência, definida por meio de programação linear, formada pelos tribunais com melhor desempenho. O IPC-Jus, então, mede a eficiência relativa de um tribunal: quanto maior seu valor, melhor o desempenho do tribunal, significando que ele foi capaz de produzir mais, com menos recursos disponíveis.

Em 2016, o índice da Justiça Estadual foi de 82\%, na Justiça do Trabalho alcançou o patamar de 90\%, tendo sido mais baixo na Justiça Federal (66\%) (CNJ, 2017). Esses resultados são superiores aos de 2012, quando o percentual médio da Justiça Estadual foi de $73 \%$ e na Justiça do Trabalho, $85 \%{ }^{3}$ (CNJ, 2013).

Considerando os dados em conjunto dos indicadores aqui apresentados, observa-se uma evolução positiva na eficiência da justiça brasileira. Porém, essa melhora precisa ser relativizada. Note que os indicadores aqui em análise têm como referencial o número de processos baixados, assim definidos:

(...) remetidos para outros órgãos judiciais competentes, desde que vinculados a tribunais diferentes; remetidos para as instâncias superiores ou inferiores; arquivados definitivamente e processos em que houve decisões que transitaram em julgado e iniciou-se a liquidação, cumprimento ou execução (CNJ, 2017, p. destaques).

Mas é possível concluir que baixar mais processos significa melhoria na atuação do judiciário brasileiro? Isso diminui a morosidade do judiciário? Em nosso entendimento, a resposta é negativa, pois isso não garante ao jurisdicionado o que ele pretendeu buscar, pois o que ele espera é uma decisão que solucione a lide.

Sabe-se que a morosidade na prestação jurisdicional é uma das principais causas da baixa confiança no judiciário brasileiro, que se encontra em queda, segundo o índice de confiança na justiça (ICJ), ficando em 34\% em 2013 e 24\% em 2017 (FGV DIREITO SP, 2017).

Ora, como pode a eficiência estar em alta e a confiança decrescendo? Supõe-se, nesse sentido, que os indicadores que vêm sendo apresentados à sociedade precisam ser aperfeiçoados, começando pela importância que dão à redução dos processos baixados, como se isso solucionasse a questão que levou o cidadão a buscar o judiciário.

Ademais, o debate sobre a eficiência desse tão relevante Poder da República não pode se restringir aos aspectos quantitativos, conduzindo a um afastamento em relação aos critérios qualitativos de avaliação dos serviços prestados aos cidadãos brasileiros. O princípio da eficiência, como versa a $\mathrm{CF} / 88$, destaca a necessidade de se buscar os melhores meios na

\footnotetext{
${ }^{3} \mathrm{O}$ dado para a Justiça Federal não foi disponibilizado no Justiça em Números de 2013.
} 
prestação jurisdicional para atingir a maior satisfação social.

\section{Considerações finais}

O texto discutiu a prestação da tutela judicial sob a ótica dos princípios da eficiência e da celeridade processual. Mostrou que o modelo de administração gerencial do Estado brasileiro, sua introjeção no Poder Judiciário e a criação do $\mathrm{CNJ}$, tendo como base esses princípios, prometiam uma melhora dos serviços prestados aos cidadãos brasileiros, incluindo a prestação jurisdicional.

Em crise, muitas críticas foram formuladas a esse poder por sua incapacidade de responder ao seu papel constitucional, seja nos conflitos individuais, na prestação de justiça ou diante dos conflitos políticos, dada a morosidade na prestação da justiça e a pouca efetividade das decisões judiciais. Outro conjunto de críticas versa sobre os impactos negativos no desempenho das empresas, nas perturbações decorrentes da não adequada proteção legal aos emprestadores do sistema financeiro e, por conseguinte, no crescimento econômico. Ou seja, insatisfação de vários setores da vida social brasileira, apesar de essa não ser uma especificidade do judiciário nacional.

Criado para fiscalizar e planejar as ações estruturais do Poder Judiciário, o CNJ vem sendo pressionado para melhorar a eficiência dos serviços e a democratização da atuação desse poder. Porém, ainda que não se neguem os avanços em termos da maior transparência ao Poder Judiciário na administração e na eficiência do serviço prestado pela justiça brasileira, a pesquisa aqui apresentada mostrou que essa evolução positiva deve ser relativizada. Muitos indicadores divulgados sobre a mesma estão pautados no número de processos baixados pelos tribunais.

Questiona-se, então, se baixar mais processos implica na melhoria na atuação do Poder Judiciário. Ora, isso não garante ao jurisdicionado uma decisão que solucione a lide que o fez buscar a justiça, tanto que sua imagem junto à população é negativa, dada a baixa confiança que pesquisas sobre o tema apontam.

Diante da inconsistência de dados que revelam a eficiência em alta e a confiança em queda, o estudo aqui apresentado conclui que os indicadores de eficiência apresentados pelo CNJ no Justiça em Números precisam melhorar sua validade que, como já mencionado, é a propriedade de um indicador bem representar o conceito a ele associado. Propõe-se, assim, a necessidade de se discutir o aperfeiçoamento desses indicadores. Em particular, questiona-se a importância que os mesmos atribuem à mera redução dos processos baixados, posto que isso não soluciona a questão que levou o cidadão a buscar o judiciário. 
Visando atender os direitos dos jurisdicionados, deve-se considerar a necessidade de tempestividade dos mesmos, com base nos critérios de duração razoável do processo, sob pena de os dados sobre a eficiência da justiça brasileira não refletirem a efetividade esperada pelo jurisdicionado, a efetiva satisfação de quem buscou a garantia ou tutela de seu direito violado.

\section{Referências bibliográficas}

AMARAL, Antônio Carlos Cintra do. O princípio da eficiência no direito administrativo. Revista Eletrônica sobre a Reforma do Estado, Salvador, nº 5, março/abril/maio, p. 06, 2006. Disponível na internet: http://www.direitodoestado.com.br. Acesso em: 13 mai 2018.

BARROSO, Luís Roberto. Interpretação e aplicação da Constituição: fundamentos de uma dogmática constitucional transformadora. $3^{\text {a }}$ Ed. São Paulo: Saraiva, 1999.

BRESSER PEREIRA, Luiz Carlos. Reforma do Estado e administração pública gerencial. Rio de Janeiro: FGV, 2001.

CALHAO, Antônio Ernani Pedroso. Justiça célere e eficiente: uma questão de governança judicial. São Paulo: LTr, 2010.

. O princípio da eficiência na administração da justiça. São Paulo: RCS, 2007.

CONSELHO NACIONAL DE JUSTIÇA - CNJ. Justiça em Números. 2013. Disponível em: http://www.cnj.jus.br/ programas-e-acoes/pj-justica-em-numeros. Acesso em: 21 de jan. 2018.

. Justiça em Números. 2017. Disponível em: http://www.cnj.jus.br/ programas-eacoes/pj-justica-em-numeros. Acesso em: 21 de jan. 2018.

DAKOLIAS, M. Court performance around the world: a comparative perspective. Washington, DC: World Bank Publications, 1999.

FARIA, José Eduardo. A crise do judiciário no Brasil. In: LIMA JUNIOR, Jayme Benvenuto (org). Independência dos juízes: aspectos relevantes, casos e recomendações. Recife: Gajop; Bagaço, 2005, p. 23-52. 
FREITAS, Juarez. Discricionariedade administrativa e o direito fundamental à boa administração pública. 2a Ed. São Paulo: Malheiros, 2007.

FUNDAÇÃO GETÚLIO VARGAS - FGV / DIREITO SP. Relatório ICJBrasil $1^{\circ}$ Semestre 2017. Disponível em: http://direitosp.fgv.br/sites/direitosp.fgv.br/files/arquivos/ relatorio_icj_1sem2017.pdf. Acesso em: 15 de mar. 2018.

GABARDO, Emerson. Princípio Constitucional da eficiência administrativa. SP. Dialética, 2002.

GICO JÚNIOR, Ivo Teixeira. A tragédia do judiciário. Revista de Direito Administrativo, v. 267, p. 163-198, 2014.

GONÇALVES, Diego Marques; SOUZA, Fábio Franzotti. As limitações da Emenda Constitucional n. 19/98 na implementação do modelo gerencial de administração pública no Brasil. Florianópolis: CONPEDI, 2014, v. 1, p. 73-87. Disponível em: http://www. publicadireito.com.br/artigos/ ?cod=cc4288ab4c5cb6a3. Acesso em: 04 de abr. 2018.

MORAIS, Janaina Jacolina. Princípio da eficiência na administração pública. 2014. Disponível em: http://www.eduvaleavare.com.br/wp-content/uploads/2014/07/ principio_eficiencia.pdf. Acesso em: 15 de mar. de 2018.

MOREIRA, Helena Delgado Ramos Fialho. Poder Judiciário no Brasil - Crise de Eficiência. Curitiba: Editora Juruá, 2004.

PLANALTO. II Pacto republicano de Estado por um sistema de justiça mais acessível, ágil e efetivo. 2009. Disponível em: http://www.planalto.gov.br/ccivil_03/Outros/IIpacto.htm. Acesso em: 22 de fev. de 2018.

REIS, Sérgio Roberto Guedes. Modelo de integração de agendas: proposta para o desenho de programas governamentais a partir do paradigma de governo aberto. In: Planejamento Brasil século XXI: inovação institucional e refundação administrativa: elementos para o pensar e o agir. Brasília: IPEA, 2015, p. 309-336. 
ROSENN, Keith S.. Judicial reform in Brazil. NAFTA: Law and Business Review of the Americas Spring, 1998, p. 19-37.

THEODORO JR, Humberto. Curso de Direito Processual Civil: Teoria Geral do Direito

Processual Civil e processo de conhecimento. $51^{\text {a }}$ Ed. Rio de Janeiro: Forense, p. 20, 2010.

YEUNG, Luciana Luk-Tai; AZEVEDO, Paulo Furquim de. Além dos "achismos" e das evidências anedóticas: medindo a eficiência dos tribunais brasileiros. Economia Aplicada, v. 16, n. 4, 2012, p. 643-663. 


\title{
A DISCRICIONARIEDADE ADMINISTRATIVA E A QUESTÃO DA RESPOSTA ADEQUADA NA FISCALIZAÇÃO TRIBUTÁRIA: UMA ANÁLISE A PARTIR DA CRÍTICA HERMENÊUTICA DO DIREITO
}

\author{
Flávio Couto Bernardes \\ Pontifícia Universidade Católica de Minas Gerais \\ Gabriel Senra da Cunha Pereira \\ Pontifícia Universidade Católica de Minas Gerais
}

\section{Resumo}

Este trabalho tem por objetivo estudar a discricionariedade administrativa na fiscalização tributária. Primeiramente far-se-á uma análise do tratamento dado à discricionariedade administrativa pela doutrina clássica brasileira. Em seguida, será feito um estudo da teoria de Lenio Luiz Streck, especificamente quanto à questão da existência de uma resposta adequada para cada caso. Por fim, analisar-se-á a fiscalização tributária como ato administrativo e as influências das teorias abordadas no presente artigo. A metodologia da pesquisa consistirá na consulta bibliográfica e à legislação que abrange o tema. O marco teórico adotado é a obra Verdade e Consenso, de Lenio Luiz Streck.

Palavras-chave: Direito Administrativo, Direito Tributário, Discricionariedade administrativa, Fiscalização tributária, Resposta adequada.

\begin{abstract}
Resumen/Résumé
This scientific work aims to study the administrative discretion in tax inspection. At first, an analysis of the treatment given to administrative discretion by classical Brazilian doctrine will be made. Then, a study of Lenio Luiz Streck's theory be made, focused on the question of the existence of an adequate answer for each case. Finally, tax inspection will be analyzed as an administrative act and the influences of the theories discussed in this article. The methodology of the research will consist of the bibliografic consultation and the legislation that covers the subject. The theoretical framework adopted is the work Truth and Consensus, by Lenio Luiz Streck.
\end{abstract}

Keywords/Palabras-claves/Mots-clés: Administrative Law, Tax Law, Administrative Discretion, Tax Inspection, Appropriate response. 


\section{Introdução}

A discricionariedade, seja ela administrativa ou judicial, é objeto de grandes

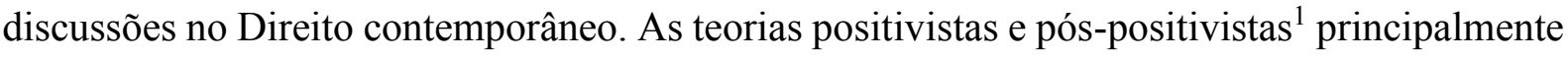
as que se debruçam sobre a construção de uma teoria da decisão jurídica, evidenciam ser a discricionariedade um tema nevrálgico do Direito.

A busca pela limitação das arbitrariedades e autoritarismos se faz ainda mais presente no paradigma do Estado Democrático de Direito (STRECK, 2017). No Brasil, as clássicas teorias administrativistas tratam a discricionariedade como elemento inexorável do ato administrativo, sob o fundamento de que é impossível a lei prever todas as possibilidades do mundo fático.

Faz-se necessário, contudo, questionar sobre a verdadeira essência da discricionariedade, que neste artigo terá enfoque no ato administrativo. Isto é, se o indivíduo investido de poder efetivamente dispõe de diversas alternativas decisórias ou não. Essa discussão remete à questão: pode-se falar na existência de uma resposta adequada na decisão administrativa?

No campo do Direito Tributário, especificamente em relação à fiscalização tributária, a pergunta que se propõe a responder é: confere-se à autoridade competente discricionariedade quanto aos atos de fiscalização que pratica?

Para o tratamento dessa questão, este artigo analisará, inicialmente, o posicionamento da doutrina clássica brasileira sobre a discricionariedade administrativa. Em seguida, discutirse-á sobre a existência de uma resposta adequada, o que será feito a partir da obra Verdade e Consenso, de Lenio Luiz Streck, a qual é admitida como referencial teórico do artigo.

Após, abordar-se-á a fiscalização tributária como tema de Direito Administrativo e se analisará a (in)existência de discricionariedade na prática de atos decisórios pela autoridade investida de poder de fiscalização, sendo este, pois, o objetivo final do artigo.

Utiliza-se metodologia exploratória de trabalho, consistente na consulta bibliográfica e jurisprudencial, bem como na análise da legislação aplicável à espécie.

\footnotetext{
${ }^{1}$ Sobre o assunto, em que pese não seja o tema central deste artigo, faz-se referência à obra "Além do Positivismo Jurídico" de autoria de Álvaro Ricardo de Souza Cruz e à obra "Direito Constitucional Financeiro" de Heleno Taveira Torres.
} 


\section{A discricionariedade na doutrina clássica brasileira}

Por discricionariedade entende-se uma certa liberdade de atuação de que goza a Administração Pública, sendo-lhe autorizado, dentro dos limites legais, valorar a oportunidade e conveniência da prática de seus atos. Nesse sentido, cita-se o Professor Celso Antônio Bandeira de Mello:

(...) Discricionariedade, portanto, é a margem de liberdade que remanesça ao administrador para eleger, segundo critérios consistentes de razoabilidade, um, dentre pelo menos dois comportamentos cabíveis, perante cada caso concreto, a fím de cumprir o dever de adotar a solução mais adequada à satisfação da finalidade legal, quando, por sua fluidez das expressões da lei ou da liberdade conferida no mandamento, dela não se possa extrair objetivamente, uma solução unívoca para a situação vertente. $(2000$, p. 8$)$

Segundo a Professora Maria Sylvia Zanella Di Pietro:

(...) Pode-se, pois, concluir que a atuação da Administração Pública no exercício da função administrativa é vinculada quando a lei estabelece a única solução possível diante de determinada situação de fato; (...) a atuação é discricionária quando a Administração, diante do caso concreto, tem a possibilidade de apreciá-lo segundo critérios de oportunidade e conveniência e escolher uma dentre duas ou mais soluções, todas válidas para o direito. (...). (2014, p. 221)

Ultrapassadas essas considerações iniciais, passa-se a expor as variadas teses doutrinárias brasileiras sobre a discricionariedade.

\subsection{Themístocles Cavalcanti}

Em sua obra Discricionariedade Administrativa e Hermenêutica, o autor Luis Henrique Madalena defende que a teoria de Themístocles Cavalcanti foi a responsável pelo início da construção da ideia de discricionariedade administrativa que até recentemente dominava no Brasil: de que o ato administrativo discricionário não poderia ser objeto de apreciação pelo Poder Judiciário (CAVALCANTI apud MADALENA, 2016).

\subsection{Hely Lopes Meirelles}

A impossibilidade de controle do mérito do ato administrativo discricionário também era defendida por Hely Lopes Meirelles, salvo nos casos de desvio ou excesso de poder. Para o referido autor, discricionário é o ato em que o intérprete tem liberdade quanto à escolha do seu 
conteúdo. Trata-se do "poder de a Administração praticá-lo pela maneira e nas condições que repute mais convenientes ao interesse público" (MEIRELLES, 2007, p. 169).

Ainda que Meirelles tenha buscado diferenciar a discricionariedade da arbitrariedade, nota-se, no autor brasileiro, a ideia de que cabe ao administrador público, conforme suas convicções próprias e pessoais, a livre escolha de uma dentre várias soluções disponíveis ao caso que se lhe apresenta.

O problema, contudo, é identificar onde se situa a fronteira entre a arbitrariedade e a discricionariedade. Não é incomum que mesmo atos praticados dentro dos limites impostos pela lei sejam arbitrários, destoados das suas finalidades precípuas.

\title{
2.3 Celso Antônio Bandeira de Mello
}

Celso Antônio Bandeira de Mello avança mais no sentido da limitação da discricionariedade ao expor que o mero fato de a lei conceder ao administrador público certa margem de ação, não significa que em todo caso concreto a decisão terá espaço para ser tomada discricionariamente:

\begin{abstract}
A existência de discricionariedade ao nível da norma não significa, pois, que a discricionariedade existirá com a mesma amplitude perante o caso concreto e nem sequer que existirá em face de qualquer situação que ocorra, pois a compostura do caso concreto excluirá obrigatoriamente algumas das soluções admitidas in abstracto na regra e, eventualmente, tornará evidente que uma única medida seria apta a cumprir-lhe a finalidade. Em suma, a discrição suposta na regra de Direito é condição necessária, mas não suficiente, para que exista discrição no caso concreto; vale dizer, na lei se instaura uma possibilidade de discrição, mas não uma certeza de que existirá em todo e qualquer caso abrangido pela dicção da regra. (MELLO, 2015, p. 991)
\end{abstract}

Mello, assim, se aproxima bastante da ideia de haver uma resposta adequada para cada caso. Mesmo que a discricionariedade exista no plano hipotético, não necessariamente se confere ao intérprete mais de uma possibilidade decisória em vista do contexto fático de cada caso. Esse ponto será muito útil no decorrer deste trabalho.

Entretanto, na doutrina de Mello ainda subsistem traços do poder decisório amparado no juízo pessoal e subjetivo do agente público. Ao tratar do mérito do ato administrativo, o jurista defende que este é o que remanesce no caso concreto quando não há possibilidade de se identificar qual seria a resposta mais adequada. Nesta hipótese, a decisão deve ser proferida conforme os critérios de conveniência e oportunidade que o administrador, a partir de sua posição mais favorável, for capaz de identificar (MELLO, 2015). 
Este é um argumento que se busca questionar neste trabalho a partir da Crítica Hermenêutica do Direito, desenvolvida por Lenio Luiz Streck: o de que o agente público investido de poder, em razão de sua posição, possui melhores condições de escolher uma dentre várias soluções para o caso concreto, como se houvesse uma neutralidade apriorística do sujeito (agente público) em relação ao objeto (caso concreto). No entanto, esta discussão será tratada mais detidamente no próximo tópico. Segue-se, pois, no desenvolvimento da teoria da discricionariedade em terras brasileiras.

\subsection{Maria Sylvia Zanella Di Pietro}

Para Maria Sylvia Zanella Di Pietro (2014), a lógica de distinção entre ato administrativo vinculado e discricionário é a mesma: os atos vinculados são aqueles que a lei não deixa opções ao administrador. Ou seja, por mera subsunção do fato à regra, encontra-se a única resposta possível. Já o ato discricionário seria aquele que a lei deixa diversas possibilidades à disposição do administrador, que poderá optar por uma delas. Para Di Pietro, qualquer dessas escolhas é válida perante o Direito.

Os critérios adotados pela autora para se escolher por uma dentre as diversas opções possíveis é que divergem dos autores anteriormente citados; para aqueles, os critérios são conveniência e oportunidade. Para Di Pietro, acrescem-se a esses dois a justiça e equidade, os quais seriam próprios da autoridade.

Di Pietro ${ }^{2}$ argumenta ainda que a discricionariedade, sob a ótica jurídica, justifica-se a partir da teoria positivista normativista kelseniana. A autora atribui ao intérprete, tal como o fazem os administrativistas anteriormente citados, o poder de acrescentar o último elemento necessário à aplicação do Direito ao caso concreto. Ao final das contas, o Direito será aquilo que o intérprete disser que é, conforme suas convicções pessoais do que vêm a ser os critérios de conveniência, oportunidade, equidade e justiça.

\footnotetext{
${ }^{2}$ Nesse sentido, cita-se: “[...] Sob o ponto de vista jurídico, utiliza-se a teoria da formação do Direito por degraus, de Kelsen: considerando-se os vários graus pelos quais se expressa o Direito, a cada ato acrescenta-se um elemento novo não previsto no anterior; esse acréscimo se faz com o uso da discricionariedade; esta existe para tornar possível esse acréscimo. [...]" (2014, p. 221-222)
} 


\subsection{Florivaldo Dutra de Araújo}

Florivaldo Dutra de Araújo (2005), valendo-se de García de Enterría, busca demonstrar que na discricionariedade a lei confere, de antemão, um número determinado ou indeterminado de opções ao administrador, e que "qualquer decisão a ser depois tomada estará previamente avalizada como juridicamente perfeita" (ARAÚJO, 2005, p. 85). Haveria, portanto, uma validação prévia do Direito em relação ao ato praticado pelo administrador, seja ele qual for, desde que inserido nos limites que a lei impôs. Qualquer decisão, uma vez proferida dentro da "moldura" do Direito, não poderia ser juridicamente fiscalizada.

No intento de limitar as arbitrariedades da Administração Pública, a lógica adotada pelos juristas aqui abordados, ao contrário, as legitima. Paradoxalmente, portanto, perde-se toda a normatividade do Direito para o subjetivismo do indivíduo investido de poder. Vem bem a calhar a lição de Madalena:

Ao fim a ao cabo, se não for possível controlar a discricionariedade administrativa, não se poderá controlar a atividade estatal, fazendo com que todas as mudanças previstas em nossa Constituição acabem por verdadeiramente perder normatividade [...]. (MADALENA, 2016, p. 47)

A noção de discricionariedade acima exposta, legitimada pelo próprio Direito como autorizador das escolhas pessoais e subjetivas do intérprete, torna cada vez mais difícil o controle do poder estatal.

Por isso, no paradigma do Estado Democrático de Direito faz-se necessário rediscutir a questão da discricionariedade administrativa a fim de que se encontre - ou ao menos se busque encontrar -, verdadeiramente, uma solução à questão dos atos arbitrários e desconectados com os objetivos fundamentais da República, que tanto ainda se praticam no âmbito da Administração Pública brasileira.

\section{A questão da resposta adequada}

\subsection{Discricionariedade administrativa e judicial}

Em sua obra Verdade e Consenso, Lenio Luiz Streck trata da discricionariedade com foco na decisão judicial. A teoria por ele elaborada critica, pois, a liberdade conferida ao juiz para decidir com base em critérios subjetivos, pessoais. Quanto ao ato administrativo, entretanto, o autor alerta que "não é correto trazer o conceito de discricionariedade 
administrativa para o âmbito da interpretação do direito (discricionariedade judicial)". E assim o justifica:

Tem sido muito comum aproximar - embora de forma equivocada - aquilo que se menciona como discricionariedade judicial daquilo que a doutrina chama de ato administrativo discricionário. Nota-se, de plano, que há aqui uma nítida diferença de situações: no âmbito judicial, o termo "discricionariedade" refere-se a um espaço a partir do qual o julgador estaria legitimado a criar a solução adequada para o caso que lhe foi apresentado a julgamento. No caso do administrador, tem-se por referência a prática de um ato autorizado pela lei e que, por esse motivo, mantém-se adstrito ao princípio da legalidade. (STRECK, 2017, p. 71)

Porém, não nos parece correta tal distinção. Se a discricionariedade administrativa decorre diretamente da lei e a discricionariedade judicial decorre das "lacunas" do Direito, ao fim e ao cabo tanto o administrador quanto o juiz encontrarão diversas possibilidades decisórias, independentemente do fundamento de cada uma dessas discricionariedades. Em qualquer dos casos, o intérprete poderá "criar" a solução que entender mais adequada ao caso concreto, pois mesmo no Direito Administrativo não há como se prever todas as hipóteses possíveis. Como bem alerta Florivaldo Dutra de Araújo (2005), a lei muitas vezes atribui um número indeterminado de possibilidades decisórias ao administrador. Nestes casos, principalmente, caberá ao intérprete encontrar uma solução não previamente estabelecida em lei para o caso concreto.

Esta afirmativa fica ainda mais clara quando se fala em fiscalização tributária, em que o espaço "concedido" pela lei ao fiscal é deveras amplo. A autoridade administrativa, nestes casos, "cria" a solução adequada ao caso concreto.

Por isso, no presente artigo segue-se a linha de Luis Henrique Madalena, para quem "não há uma classe distinta de discricionariedade" (2016, p. 20), seja ela administrativa ou judicial.

Ou seja, a mesma margem de atuação deixada ao juiz, também é admitida ao administrador! Com isso, tem-se não apenas a identidade das "discricionariedades" judicial e administrativa, mas a verificação de que a discricionariedade de que aqui se fala, seja no tocante a sua qualificação como administrativa ou judicial e, principalmente na distinção em intencional ou não, é dada pelo próprio intérprete, com base no sentido que provê à determinação legal e a quem a mesma se direciona. (MADALENA, 2016, p. 208)

O que se pretende discutir neste trabalho é exatamente o grau de liberdade dado ao intérprete, administrador público que age na qualidade de fiscal tributário. 


\title{
3.2 A Crítica Hermenêutica do Direito
}

Seria por demais pretensioso tentar esgotar ou mesmo abarcar neste artigo toda a teoria de Lenio Luiz Streck. Todavia, faz-se necessário traçar, para os fins deste estudo, as bases e linhas gerais da Crítica Hermenêutica do Direito; afinal, é com ela que se pretende fundamentar as conclusões decorrentes da primeira etapa desta pesquisa.

A Crítica Hermenêutica do Direito (CHD) rompe com a típica separação realizada no plano das ciências, entre sujeito e objeto: o sujeito como indivíduo neutro, isento de juízos e conceitos prévios, capaz de observar o objeto e dele extrair informações para produzir conhecimento. No Direito, a noção que Streck busca desconstruir é a de que o intérprete (sujeito) é isento e neutro em relação ao texto (objeto), de cuja leitura o intérprete simplesmente lhe atribui o sentido que melhor lhe aprouver e, depois, aplica-o.

Nas palavras do autor:

\begin{abstract}
Há sempre um sentido que nos é antecipado. Opto, desse modo, por adotar a matriz hermenêutica, como superação do esquema sujeito-objeto, representada pela busca na filosofia de um fundamento para o conhecimento, a partir do discurso em que impera a ideia de juízo (Stein).

$[\ldots]$

Dito de outro modo, enquanto a dogmática jurídica tenta explicar o direito, a partir da ideia de que o ser (o sentido) é um ente (isto é, como se o conceito de "coisa julgada ou "direito adquirido" fosse um ente apreensível como ente), a partir dessa análise hermenêutica que proponho, pretendo mostrar que há uma clivagem entre nós e o mundo, porque nunca atingimos o mundo dos objetos de maneira direta, mas, sim, sempre pelo discurso. E, como pretendo demonstrar na continuidade, isso nem de longe pode significar uma espécie de "livre disposição do discurso"; ao contrário, é exatamente a hermenêutica que melhor propiciará as condições para encontrar respostas corretas no Direito. (STRECK, p. 252-253)
\end{abstract}

Essa ideia parte da viragem linguística e do rompimento com a filosofia da consciência, para a noção de que o intérprete possui, antes mesmo do contato com o texto a ser compreendido, pré-compreensões e de juízos preexistentes. Assim, o texto não é compreendido por partes: compreensão, interpretação e, por fim, aplicação. Essas três fases se manifestam de uma só vez, no momento chamado de círculo da compreensão: o texto é compreendido singular para o todo e do todo para o singular (MADALENA, 2016).

Em outras palavras, o texto não existe em uma espécie de textitude metafísica; o texto é inseparável de seu sentido; textos dizem sempre respeito a algo da facticidade; interpretar um texto é aplicá-lo; daí a impossibilidade de cindir interpretação de aplicação. (STRECK, 2017, p. 254)

É a partir desse pensamento jusfilosófico que Lenio Streck combate toda e qualquer atividade discricionária do Poder Judiciário, cujo alcance também abarca os atos 
administrativos, sem se afastar da normatividade.

A suposta neutralidade do intérprete serve, na verdade, como roupagem para justificar - e legitimar - a discricionariedade tal como é conhecida, exposta no tópico anterior deste artigo, no sentido de que o agente tem, a priori, o poder de, conforme seus próprios valores, optar por uma dentre várias respostas possíveis, desde que dentro dos limites da lei. Qualquer uma dessas respostas, seja ela qual for, o Direito admitiria, de antemão, como válida.

Não nos parece ser este, porém, o pensamento que mais se adequa à nova ordem constitucional brasileira. Como dito na introdução deste trabalho, um dos grandes desafios do Direito contemporâneo é justamente a limitação das discricionariedades e arbitrariedades, mas o pensamento dominante não só não o faz como também as protege. Não se afigura possível, no paradigma do Estado Democrático, entender-se qualquer ato administrativo como previamente avalizado pelo Direito.

\subsection{Os princípios em Lenio Luiz, Streck}

A discussão acerca da resposta adequada está intimamente ligada à noção que se tem de princípios, embora naturalmente não se tenha a pretensão de tratar dos principais doutrinadores que discutem a natureza deste instituto jurídico, motivo pelo qual se aponta de forma sucinta a síntese de alguns juristas.

Para Robert Alexy (2015), princípios são mandados de otimização, ou melhor, são normas que comandam que algo seja realizado na maior medida possível em relação às possibilidades fáticas e jurídicas. E, diferentemente das regras, que se aplicam por mera subsunção, os princípios se aplicam pela ponderação.

Muito embora Alexy tenha se esforçado para reduzir a subjetividade do intérprete na aplicação dos princípios, com o desenvolvimento do mecanismo da ponderação ${ }^{3}$, ainda assim subsiste o arbítrio, uma vez que a atribuição de pesos aos princípios que devem compor a fórmula por ele criada se dá com base em critérios unicamente subjetivos do julgador. Para Alexy, ao atribuir os pesos dos princípios pela lei da ponderação, o julgador deve fazê-lo imbuído de uma pretensão de correção a ser justificada por meio do discurso (2015).

A teoria de Alexy confere uma enorme abertura conferida ao intérprete quando este se defronta com os princípios. O próprio filósofo deixa isso claro ao dizer que os princípios têm quatro extremos: o grau mais elevado na estrutura escalonada do Direito interno; a maior força

\footnotetext{
${ }^{3}$ Pela lei da ponderação, Alexy propõe um método que chama de fórmula do peso, para definir qual princípio terá prevalência em relação ao outro em determinado caso concreto.
} 
executória; regulamentam os objetos de maior importância; e têm a maior medida de abertura.

Streck critica a ideia desenvolvida por Alexy ao defender que os princípios não têm um grau maior de abertura e nem conferem ao intérprete mais liberdade decisória. Para ele, os princípios inserem o mundo dos fatos no Direito e, com base nisso, eles vêm para fechar a interpretação e diminuir o espaço da discricionariedade (STRECK, 2017).

Ao exercer essa função de incluir o mundo dos fatos no Direito, os princípios passam a suprir uma lacuna que a clássica noção de discricionariedade não o faz. Por essa compreensão tradicional, ocorrida determinada hipótese de incidência, o administrador encontra-se livre para escolher uma dentre diversas alternativas igualmente válidas, que o Direito não poderia invalidar. Segundo essa lógica, então, haveria uma zona de livre decisão administrativa, situada no consequente da norma jurídica. Neste caso, os fatos concretos, que teriam o poder de determinar apenas uma decisão, estão fora do alcance do Direito.

Assim, abre-se espaço ao argumento de que o administrador pode decidir conforme sua escolha pessoal, já que, cumprido o antecedente da norma, o consequente torna-se simplesmente escolher uma das hipóteses abstratamente previstas no texto legal, as quais são previamente avalizadas pelo Direito.

Aqui, resgata-se a lição de Celso Antônio Bandeira de Mello, para quem "a compostura do caso concreto excluirá obrigatoriamente algumas das soluções admitidas in abstracto na regra e, eventualmente, tornará evidente que uma única medida seria apta a cumprir-lhe a finalidade" (2015, p. 991). São os fatos concretos, portanto, que reduzem a discricionariedade do intérprete.

Então, conforme a compreensão trazida por Streck, ao se analisar os fatos para o mundo do Direito, os princípios exercem uma função integrativa no âmbito do sistema normativo, reduzindo o âmbito de discricionariedade do intérprete. Para ele, "o novo paradigma (constitucionalismo principiológico) não proporcionou maior liberdade aos juízes. Princípios, ao superarem as regras, proporciona(ra)m a superação da subsunção. Princípios não facilitam atitudes decisionistas e/ou discricionárias." (STRECK, 2017, p. 276).

Significa dizer, assim, que a discricionariedade que a lei confere à autoridade não é liberdade de decidir conforme uma vontade subjetiva, mas sim decidir levando em consideração os fatos concretos que se lhe apresentam no contexto do sistema jurídico. Em outras palavras, a normatividade do Direito não se encerra com a prática do ato administrativo após a escolha de uma dentre diversas possibilidades decisórias hipotéticas previstas (ou não) em lei; ela perdura quando da tomada da decisão, que deve estar vinculada aos princípios aplicáveis, assim como às demais regras positivadas. 
Nesse sentido, não há como simplesmente se utilizar de fundamentações textuais e/ou estruturais prévias ao caso que se apresenta ao agente do Estado, impondo-lhe uma razão abstrata, que de maneira inconsciente, busca afastar os preconceitos gerados pelo atuar de cada juízo. A Constituição já não se encontra em tal paradigma. Busca, sim, uma solução correta em cada caso, a qual será correta unicamente em face daquele evento, dados seus específicos fundamentos, os quais devem restar devidamente expostos. Trata-se do direito fundamental a obtenção de resposta correta de que fala Streck. (MADALENA, 2016, p. 181)

Logo, a noção de princípio como elemento integrativo carregado de faticidade e, por isso mesmo, limitador da discricionariedade, é essencial à discussão que se traz neste trabalho, objetivando exatamente delimitar o âmbito normativo que o norteia.

\subsection{A resposta adequada no ato administrativo}

Demonstradas as bases que sustentam o argumento a favor da existência de uma resposta adequada para cada caso, é tempo de se refletir sobre o modo como tal pode se dar no âmbito do ato administrativo, que não possui uma espécie distinta de discricionariedade em relação ao ato judicial.

Como muito aqui se falou, não há mais espaços para arbítrio, devendo se eliminar os subjetivismos que não possuem base normativa sólida no paradigma do Estado Democrático de Direito. Na era dos princípios constitucionais com força normativa substancial, não se admite que o administrador tome decisões baseadas em suas próprias convicções pessoais, escolhendo livremente por uma dentre diversas possibilidades abstratas previstas em lei.

Admitir que o Estado delegue para o administrador escolhas que ficam ao seu alvedrio, partindo da definição de princípios em uma concepção teleológica, em que estes convertem-se em mandados de otimização que possuem o condão de abrir a interpretação do direito e abrir o leque de possíveis respostas, apresenta-se claramente antidemocrático. Não é possível que se realize uma interpretação do direito em que a democracia, de forma democrática, delegue a definição do direito para instrumentos não democráticos, o que é o mesmo que dizer que se escolhe democraticamente não ser mais democrático. Ora, qualquer método interpretativo que leve a um tal resultado de subverter a Constituição em múltiplas formas, indiscutivelmente retirando-lhe normatividade, não pode ser tida como autêntica, não sendo nada além de verdadeiro golpe ao Estado Democrático de Direito.

$[\ldots]$

Por isso, mais uma vez reafirma-se que em um Estado Democrático de Direito, como se pretende no Brasil, princípios devem ser tidos como deontológicos, de modo a estreitar a interpretação do Direito, especificando a resposta correta e não abrindo a possibilidade de diversas respostas serem tidas como aceitáveis, mesmo que uma sejam mais e outras menos corretas. (MADALENA, 2016, p. 210-212)

Os fatos concretos de cada caso vinculam o intérprete a decidir conforme o Direito, que não atém sua força normativa ao momento da "escolha", mas sim da conjugação das regras 
previstas no ordenamento jurídico para o tratamento daquela matéria, não se desprezando os princípios ou mesmo os aplicando isoladamente. $\mathrm{O}$ mundo dos fatos, trazido ao mundo do Direito pelos princípios, imporá ao administrador a melhor decisão, que será tida como adequada.

Somente é possível se dizer que há várias soluções igualmente adequadas enquanto se está no plano abstrato da norma. Trazidos os fatos, surgirá a melhor resposta, a resposta adequada. Na conclusão de sua obra, Luis Henrique Madalena (2016) cita diversos exemplos que esclarecem o que aqui se busca demonstrar. O principal deles é o caso de um viaduto construído na cidade de Curitiba/PR ao custo de aproximadamente 85 milhões de reais. Do custo total da obra, a maior parte se deveu a uma especificidade arquitetônica, denominada de “obra de arte especial”. Segundo esclarece Madalena, sem a questão puramente estética, a obra teria custado aproximadamente 10 milhões de reais.

No primeiro momento, quando a Administração se vê diante dos recursos financeiros disponíveis para a construção de estruturas viárias, a lei, abstratamente, autoriza que o gestor público opte sobre qual ou quais estruturas serão essas, para quais finalidades, e assim por diante. Mas, quando se lhe apresentam os fatos, o espaço de discricionariedade do administrador se fecha diante da necessária observância dos princípios e objetivos fundamentais da República instituídos na Carta de 1988.

Dessa forma, não foi constitucionalmente correta a decisão de se elevar a tal ponto o custo da construção (aproximadamente o óctuplo) em razão de questões puramente estéticas, em detrimento do alcance dos objetivos fundamentais da República previstos no art. $3^{\circ}$ da Constituição da República Federativa do Brasil de 1988, bem como as regras que determinam a responsabilidade fiscal para se alcançar a estabilidade econômica propagada no sistema. Isto porque, a base arquitetônica poderia ser a adequada ao custo sem que a obra simplesmente desconsiderasse este aspecto.

Neste sentido Madalena arremata:

Não se trata de uma digressão barata e ideológica, seja de esquerda ou de direita, que eventualmente desconsideraria que a verba advinda do PAC, certamente por meio de um convênio, restaria vinculada à obra para o qual inicialmente foi firmado. As considerações que aqui são tecidas não param em uma mera questão dogmática como essa, para conhecimento da qual basta entender o que consubstanciado pelo direito positivo, sem a necessidade de qualquer abordagem crítica. Aqui se questiona a atividade administrativa como um todo, seja a perpetrada na esfera federal pela vinculação de recursos disponibilizada sem o devido controle, seja a levada a cabo pela esfera municipal por meio do engendramento de obra dissonante do direito, de um Direito necessariamente transformados, como o imposto pela Constituição e que apenas pode ser alcançado com uma teoria do direito muito mais sofisticada e adequada aos avanços da filosofia, do que aí se apresenta. 
Uma infinidade de exemplos se poderiam citar aqui, a fim de demonstrar como na Administração Pública a questão da discricionariedade pode - e deve - ser enfrentada. Escolhas com base em critérios pessoais e subjetivos, desconectadas do mundo dos fatos e dos princípios fundamentais do Estado Democrático de Direito são, infelizmente, muito frequentes.

Assim, pode-se afirmar que também na atividade administrativa o cidadão tem o direito fundamental à resposta juridicamente adequada, que será aquela que melhor atenderá aos comandos do Direito diante do contexto fático do caso concreto, observando os limites postos sem deixar de se levar em consideração o princípio da separação dos poderes.

\subsection{A fiscalização tributária}

A fiscalização tributária é espécie do gênero atividade administrativa, por se tratar, evidentemente, de ato proveniente da Administração Pública, por meio de seus agentes fiscais. Todo o agir estatal tributário se formaliza através de atos administrativos ordenados num procedimento estabelecido pela legislação, sendo que este conjunto é imprescindível para o desenvolvimento válido e regular da físcalização e, especialmente, do ato de lançamento tributário consagrado no art. 142, da Lei Complementar n. 5.172, de 25 de outubro de 1966 (CTN) (BRASIL, 1966).

Os atos de fiscalização tributária atendem a todos os requisitos configuradores do ato administrativo apontados por Celso Antônio Bandeira de Mello (2015), tratando-se de manifestação que: (i) produz efeitos no mundo jurídico, a fim de certificar ou declarar direitos ou deveres; (ii) advém do Estado, por meio de seus agentes; (iii) é exercida no uso do poder de polícia, regida, pois, por normas de Direito Público; e (iv) decorre e se delimita diretamente da lei. Concordam com essa assertiva Tiago Cappi Janini e Ana Luiza Godoy Pulcinelli:

Parece não haver dúvidas de que a atividade de fiscalização tributária caracteriza-se como um ato da Administração Pública, sujeitando-se, portanto, ao regime jurídico administrativo, ou seja, ao conjunto de regras de princípios que outorgam identidade ao direito administrativo em face do direito privado, caracterizado pelo binômio prerrogativas/restrições. Atualmente, é importante consignar que os princípios ganham papel de relevo na normatização das relações jurídicas, especialmente as de direito público. (JANINI; PULCINELLI, 2016, p. 350)

No plano infraconstitucional, a fiscalização tributária está prevista no art. 194 e seguintes do CTN (BRASIL, 1966). O referido artigo, a propósito, desde logo traz consigo o princípio da legalidade, ao estabelecer que a legislação tributária regulará a competência e os poderes das autoridades administrativas em matéria de fiscalização. 
Portanto, assim como ocorre com os atos administrativos em geral, a fiscalização tributária está adstrita ao princípio da legalidade. Entretanto, como já se viu, o mero fato de determinado ato fiscalizatório estar previsto em lei não significa, por si só, que ele tenha sido praticado conforme o Direito. Invoca-se novamente a lição de Janini e Pulcinelli:

Entretanto, não basta uma lei determinando as diretrizes para a atividade fiscalizatória ser considerada lícita. Requer-se que a sua produção tenha seguido os dispositivos constitucionais, especialmente os direitos individuais do contribuinte. Ademais, a atividade fiscalizatória também deve respeitar os direitos fundamentais. (JANINI; PULCINELLI, 2016, p. 360)

Não basta que o fiscal, no exercício de sua função, simplesmente execute um dos atos previstos em lei. Essa escolha, como se demonstrou, não é compatível com o Estado Democrático de Direito.

Como se está a falar em poder de polícia, por conseguinte em uma relação de verticalidade entre o Estado e o indivíduo, e também por consequência em invasão do âmbito da vida individual da pessoa, o exercício da fiscalização tributária relaciona-se intimamente com os direitos fundamentais previstos no art. $5^{\circ}$, da CRFB/1988.

Considerado o poder conferido por lei à autoridade fiscal em relação às medidas que, em abstrato, podem ser tomadas, não é difícil que o excesso por parte do agente público configure, de imediato, violação aos direitos individuais estabelecidos por cláusula pétrea constitucional.

Sobre isso, Celso Antônio Bandeira de Mello (2015) assim argumenta:

\begin{abstract}
Mormente no caso da utilização de meios coativos, que, bem por isso, interferem energicamente com a liberdade individual, é preciso que a Administração se comporte com extrema cautela, nunca se servindo de meios mais enérgicos que os necessários à obtenção do resultado pretendido pela lei, sob pena de vício jurídico que acarretará a responsabilidade da Administração. Importa que haja proporcionalidade entre a medida adotada e a finalidade legal a ser atingida.

[...]

Toda coação que que exceda ao estritamente necessário à obtenção do efeito jurídico licitamente desejado pelo Poder Público é injurídica. (MELLO, 2015, p. 867)
\end{abstract}

No caso da fiscalização tributária, o mínimo é o máximo: o fiscal não pode exceder o estritamente necessário à consecução dos objetivos pretendidos com a fiscalização, sob pena de o ato praticado não se compatibilizar com o Direito vigente.

O Supremo Tribunal Federal (STF) já se debruçou sobre o tema e consolidou, nas Súmulas n. $70^{4}$ e $373^{5}$, o entendimento de que é vedada a atividade fiscal como meio coercitivo

\footnotetext{
4 "É inadmissível a interdição de estabelecimento como meio coercitivo para cobrança de tributo".

5 "É inadmissível a apreensão de mercadorias como meio coercitivo para pagamento de tributos".
} 
para o pagamento de tributo.

É neste ponto que se retorna à questão da resposta adequada, desenvolvida ao longo deste trabalho. O agente fiscalizador, no exercício de suas atividades, pode se deparar com mais de uma possibilidade de diligência prevista abstratamente pela lei, tais como examinar as mercadorias ou apenas os documentos que a elas se referem. O agente fiscal pode optar livremente por uma das duas diligências ou há uma solução mais adequada sob a ótica do Direito?

Mesmo se houver apenas uma diligência prevista em lei, ainda assim pode caber-lhe outras atribuições necessárias ao cumprimento da norma. Por exemplo, imagine-se o físcal que requisita a determinada empresa a apresentação de documentos comprobatórios do cumprimento das obrigações tributárias. A lei prevê a possibilidade de requisitar os referidos documentos, mas não em qual prazo eles devem ser apresentados ao agente público. Qual prazo deverá ser concedido pelo fiscal à empresa? Há mais de uma possibilidade?

Em nosso entendimento, há apenas uma resposta jurídica e constitucionalmente adequada. Conforme expusemos, por mais que a norma estabeleça um número determinado ou indeterminado de decisões passíveis de serem tomadas, o agente público não está livre para decidir por qualquer delas conforme suas próprias convicções pessoais, assim como o Direito não avaliza previamente qualquer uma destas decisões.

No caso da fiscalização tributária, a própria natureza invasiva da atividade na esfera privada dos indivíduos impõe que sejam trazidos para o contexto os fundamentos da República Federativa do Brasil e, principalmente, os direitos individuais fundamentais previstos no art. $5^{\circ}$ da CRFB/1988. Serão tais princípios os responsáveis por integrar o mundo dos fatos ao mundo meramente abstrato da norma, vinculando assim a decisão da autoridade a apenas uma possível. Vêm a calhar novamente as lições de Luís Henrique Madalena: “Em suma, sempre há uma resposta correta, que melhor satisfaz as exigências, os deveres impostos ao Estado pela Constituição e pela inescapável temporalidade.” (2016, p. 157).

Numa linha diferente daquela aqui tratada, admitindo a restrição de direitos fundamentais claros do cidadão-contribuinte, especialmente ao admitir a intervenção da fiscalização tributária sem prévia ordem judicial para tanto na questão da busca e apreensão de documentos, destaca-se a obra do Professor Onofre Alves Batista Júnior: 
(...) o objetivo maior da Fiscalização Tributária não é o de simplesmente proporcionar um maior fluxo de recursos para um estado descompromissado com o bem comum. Ao desenhar um "Estado Social Tributário de Direito", o constituinte de 1988, como não podia deixar de ser, esculpiu princípios norteadores da atividade fiscal, compatíveis com a sua orientação.

Portanto, cabe retomar o nosso conceito de Poder de Polícia Fiscal (poder de limitar liberdades das pessoas, de forma a assegurar a justa tributação), para reafirmar que, se num passado, o maior fluxo de recursos aos cofres públicos era a preocupação exclusiva da Fiscalização Tributária, hoje, segundo as letras da própria Constituição Federal, existem outros interesses a serem perseguidos, como o de assegurar a isonomia na tributação, a justiça fiscal, a livre concorrência sem as mazelas que nela introduzem as práticas evasivas. (2001, p. 232).

Apesar da oscilação da jurisprudência dos Tribunais de segunda instância, cumpre colacionar decisão do Supremo Tribunal Federal no sentido de expressar o dever da administração tributária agir em consonância com os direitos fundamentais encartados na Carta Magna (STF, ADI 2551 MC-QO/MG, 2006):

Ação Direta de Inconstitucionalidade - Taxa de Expediente do Estado de Minas Gerais - DPVAT - Incidência da referida taxa de expediente sobre as sociedades seguradoras - Alegação de ilegitimidade ativa das entidades sindicais que fizeram instaurar o processo de fiscalização normativa abstrata - Inocorrência - Pertinência temática figurada - Alegada utilização do controle normativo abstrato para a defesa de interesses individuais e concretos - Não-caracterização - Reconhecimento, pelo relator da causa, de que se reveste de densidade jurídica a pretensão de inconstitucionalidade deduzida pelos litisconsortes ativos - Inobservância, na espécie, da relação de razoável equivalência que necessariamente deve haver entre o valor da taxa e o custo do serviço prestado ou posto à disposição do contribuinte - ofensa aos princípios constitucionais da não-confiscatoriedade $(\mathrm{CF}$, art. 150 , IV) e da proporcionalidade $\left(\mathrm{CF}\right.$, art. $\left.5^{\circ}, \mathrm{LIV}\right)$ - Entendimento do relator de que, não obstante configurado o requisito pertinente à plausibilidade jurídica, não se revela presente, no caso, o pressuposto do "periculum in mora" - Decisão do Plenário, no entanto, que reconheceu configurada, na espécie, a situação caracterizadora do "periculum in mora", o que o levou a não referendar, por tal razão, a decisão do Relator Consequente deferimento da medida cautelar. Inadequação do controle normativo abstrato para a defesa de interesses individuais e concretos: situação inocorrência na espécie. Consequente idoneidade jurídica do meio processual utilizado. (...) A garantia constitucional da não-confiscatoriedade. - O ordenamento constitucional brasileiro, ao definir o estatuto dos contribuintes, instituiu, em favor dos sujeitos passivos que sofrem a ação fiscal dos entes estatais, expressiva garantia de ordem jurídica que limita, de modo significativo, o poder de tributar de que o Estado se acha investido. Dentre as garantias constitucionais que protegem o contribuinte, destaca-se, em face de seu caráter eminente, aquela que proíbe a utilização do tributo - de qualquer tributo - com efeito confiscatório (CF, art. 150, IV). - A Constituição da República, ao consagrar o postulado da não-confiscatoriedade, vedou qualquer medida, que, adotada pelo Estado, possa conduzir, no campo da fiscalidade, à injusta apropriação estatal do patrimônio ou dos rendimentos dos contribuintes, comprometendo-lhes, em função da insuportabilidade da carga tributária, o exercício a uma existência digna, ou a prática de atividade profissional lícita, ou, ainda, a regular satisfação de suas necessidades vitais (educação, saúde e habitação, p. ex.). - Conceito de tributação confiscatória: jurisprudência constitucional do Supremo Tribunal Federal (ADI 2.010-MC/DF, Rel. Min. CELSO DE MELLO, v.g.) e o magistério da doutrina. A questão da insuportabilidade da carga tributária. TAXA: CORRESPONDÊNCIA ENTRE O VALOR EXIGIDO E O CUSTO DA ATIVIDADE ESTATAL. (grifo nosso) (...) (BRASIL, 2006) 
À luz do exposto, depreende-se que os princípios basilares do procedimento fiscal brasileiro advêm do Estado Democrático de Direito e têm por objetivo a consonância entre os interesses públicos e os interesses sociais. Dessa forma, a ação da administração tributária deve ocorrer dentro do respeito aos cidadãos e aos direitos, garantia e liberdades que lhes concernem.

As prerrogativas conferidas à Fiscalização pelo ordenamento jurídico não podem ser entendidas como privilégios. Por certo, elas visam proporcionar as condições para que a atuação da Administração Pública seja eficaz e cumpra seus desideratos previstos constitucionalmente.

\section{Conclusão}

A Constituição da República de 1988 instaurou no Brasil o paradigma do Estado Democrático de Direito, com o rompimento do regime autoritário até então vigente. Inaugurouse, assim, uma nova era, em que não mais se admitem os arbítrios, o personalismo, a concentração de poderes na figura de um indivíduo solipsista.

Apesar disso, a cultura jurídica brasileira ainda se encontra apegada a conceitos e classificações incompatíveis com a nova ordem constitucional, as quais, com o intuito de reduzir as arbitrariedades, acabam por legitimá-las.

No campo do Direito Administrativo, a noção desenvolvida pela doutrina clássica acerca dos atos administrativos, dividindo-os em vinculados e discricionários, confere ao indivíduo investido de poder, o agente estatal, o direito de escolher uma dentre várias respostas possíveis conforme suas convicções pessoais e subjetivas.

Porém, admitir-se que o intérprete dispõe de diversas alternativas decisórias diante do fato concreto, e que todas elas são previamente avalizadas pelo Direito, é admitir que os fatos surgidos no mundo concreto não são alcançados por esse mesmo Direito. Igualmente, é admitir que os princípios fundamentais da República não possuem força normativa substancial, mas sim que são meros mandados de otimização, possibilitando uma abertura interpretativa dentro do sistema.

A Crítica Hermenêutica do Direito desenvolvida por Lenio Luiz Streck busca romper com essa ideia a partir da digressão filosófica. Com a virada linguística, viu-se que a linguagem não é mais interposta entre o sujeito (intérprete) e o objeto (texto). O intérprete não é neutro e isento em relação às prescrições normativas, ele está jogado no mundo dos fatos, de modo que qualquer interpretação a ser dada já traz consigo uma carga prévia de juízos e précompreensões, que devem se ater necessariamente ao âmbito do sistema normativo vigente.

Os princípios, ademais, não são meros mandados de otimização, mas têm força 
substantiva e exercem uma função integrativa, que associada ao mundo dos fatos, necessariamente "fechará" as possibilidades decisórias.

Dessa ideia resplandece o pensamento de que não há mais espaço para decisões solipsistas, amparadas em escolhas pessoais, destoadas da força normativa constitucional que vincula o intérprete.

O agente público, portanto, está sempre vinculado aos fatos e aos princípios fundamentais estabelecidos na Constituição da República de 1988, não podendo deles prescindir no momento da decisão. Só é possível falar-se em discricionariedade se nos apegarmos às possibilidades descritas na norma abstrata e abdicarmos do mundo dos fatos e da força e da função que os princípios exercem no Estado Democrático de Direito.

No caso da fiscalização tributária, viu-se que esta é uma espécie de ato administrativo, e, portanto, o agente público que a pratica também se vincula diante dos fatos e dos princípios. Aqui, ainda mais, se deve atentar para a força dos direitos individuais estabelecidos no art. $5^{\circ}$ da CRFB/1988, em razão da natureza invasiva da fiscalização tributária na esfera privada das pessoas.

A conclusão a que se chega é, assim, a de que é possível se identificar uma resposta adequada nos atos administrativos de fiscalização tributária. A melhor solução será aquela que importar na menor lesão possível às liberdades individuais, e poderá ser encontrada a partir dos fatos concretos que se apresentarem ao intérprete, que tem por dever decidir levando em conta os princípios da República, principalmente os direitos e garantias fundamentais do indivíduo.

\section{Referências bibliográficas}

ALEXY, Robert. Teoria Discursiva do Direito. 2 ed., São Paulo: Forense, 2016.

ARAÚJO, Florivaldo Dutra de. Motivação e controle do ato administrativo. 2 ed., Belo Horizonte: Del Rey, 2005.

BATISTA JÚNIOR, Onofre. O poder de polícia fiscal. Belo Horizonte: Mandamentos, 2001.

BRASIL. Lei Complementar n. 5.172, de 25 de outubro de 1966. Dispõe sobre o Sistema Tributário Nacional e institui normas gerais de direito tributário aplicáveis à União, Estados e Municípios. Diário Oficial da União, Brasília, 25 out. 1966. Disponível em: < http://www. planalto.gov.br/ccivil_03/leis/L5172Compilado.htm> Acesso em: 25 jan. 2018. 
BRASIL. Constituição da República Federativa do Brasil de 1988. Brasília: Senado, 1988. Nós, representantes do povo brasileiro, reunidos em Assembléia Nacional Constituinte para instituir um Estado Democrático, destinado a assegurar o exercício dos direitos sociais e individuais, a liberdade, a segurança, o bem-estar, o desenvolvimento, a igualdade e a justiça (...). Diário Oficial da União, Brasília, 5 out. 1988. Disponível em: $<$ http://www.planalto. gov.br/ccivil_03/Constituicao/Constituicao.htm>. Acesso em: 25 jan. 2018.

BRASIL. Supremo Tribunal Federal. Súmula n. 70. Brasília, 1963. Disponível em: $<$ http://www.stf.jus.br/portal/jurisprudencia/listarJurisprudencia.asp?s1=70.NUME.\%20NAO \%20S.FLSV.\&base=baseSumulas>. Acesso em: 25 jan. 2018.

BRASIL. Supremo Tribunal Federal. Súmula n. 323. Brasília, 1963. Disponível em: $<$ http://www.stf.jus.br/portal/jurisprudencia/listarJurisprudencia.asp?s1=323.NUME.\%20NA O\%20S.FLSV.\&base=baseSumulas>. Acesso em: 25 jan. 2018.

BRASIL. Supremo Tribunal Federal. Questão de Ordem e Ag. Reg. na Ação Cautelar ADI 2551 MC-QO/MG. Agravante: União. Agravado: Estado do Amazonas e outros. Brasília. 25 de maio de 2006. Diário de Justiça, 16 jun. 2006. Disponível em: < http://redir.stf.jus.br/paginadorpub/paginador.jsp?docTP=AC\&docID=353776>

CRUZ, ÁlVARO RICARDo DE SOUZA. Além do Positivismo Jurídico. $1^{\text {a }}$ Ed., Belo Horizonte: Arraes, 2013.

DI PIETRO, Maria Sylvia Zanella. Direito Administrativo. 27 ed., São Paulo: Atlas, 2014.

JANINI, Tiago Cappi; PULCINELLI, Ana Luiza Godoy. A fiscalização tributária e seus limites: uma análise a partir do princípio da legalidade e dos direitos fundamentais do contribuinte. Revista de Direito Tributário e Financeiro, n. 2, 2016. Disponível em: < http://www.indexlaw.org/index.php/direitotributario/article/download/1414/pdf>. Acesso em: 25 jan. 2018.

MADALENA, Luis Henrique. Discricionariedade Administrativa e Hermenêutica. Salvador: JusPodivm, 2016. 
MEIRELLES, Hely Lopes. Direito Administrativo Brasileiro. 33 ed., São Paulo: Malheiros, 2007.

MELLO, Celso Antônio Bandeira de. Curso de Direito Administrativo. 32 ed., São Paulo: Malheiros, 2015.

MELLO, Celso Antônio Bandeira de. Discricionariedade e Controle Jurisdicional. $2^{\mathrm{a}}$ ed. São Paulo: Malheiros, 2000.

STRECK, Lenio Luiz. Verdade e Consenso. 6 ed., São Paulo: Saraiva, 2017.

TORRES, HELENO TAVEIRA. Direito Constitucional Financeiro. $1^{\text {a }}$ ed., São Paulo: Revista dos Tribunais, 2014 


\title{
A EFETIVIDADE DA GARANTIA DE EFICIÊNCIA NO CONTROLE DE ATOS DOS CARTÓRIOS DO PODER JUDICIÁRIO CATARINENSE
}

\author{
Tatiana Bettiol Carneiro \\ Universidade Federal de Santa Catarina
}

\begin{abstract}
Resumo
A efetividade de eficiência resulta na objetivação do máximo de aproveitamento dos atos de administração do Poder Judiciário Catarinense. As limitações das formas de correições utilizadas atualmente na Justiça Catarinense, com caráter eminentemente repressivo não proporcionam a melhoria almejada. Desta forma, a indagação é se a revisão da postura da Administração do Judiciário em controle operacional interferirá de alguma forma, positivamente, no acesso à justiça, no sentido pleno de sua percepção, garantido constitucionalmente. Esse artigo pretende analisar a auditoria dos cartórios judiciais catarinenses, por meio de questões como controle da administração pública, auditoria operacional e a eficiência do Poder Judicante.
\end{abstract}

Palavras-chave: Controle da Administração Pública, Auditoria Operacional, Cartório Judicial, Acesso à Justiça, Eficiência

\begin{abstract}
Resumen/Résumé
The effectiveness of efficiency results in the objectivation of maximum use of the administrative acts of the Judiciary of Santa Catarina. The limitations of the forms of correction currently used in the Santa Catarina Justice, with an eminently repressive character, do not provide the desired improvement. In this way, the question is whether the review of the Judiciary Administration's position on operational control will in any way interfere, positively, with access to justice, in the full sense of its perception, guaranteed by the Constitution. This article intends to analyze the audit of the judicial registries of Santa Catarina, through questions such as control of the public administration, operational audit and the efficiency of the Judicial Power.
\end{abstract}

Keywords/Palabras-claves/Mots-clés: Control of Public Administration, Operational Audit, Judicial office, Access To Justice, Efficiency 


\section{Introdução}

A busca pela efetividade de eficiência resulta na possibilidade de sua aplicação em situações divergentes, na objetivação do máximo de aproveitamento dos atos de administração do Poder Judiciário Catarinense.

A pretensão desse artigo é o questionamento acerca das limitações das formas de correições utilizadas atualmente na Justiça Catarinense, com caráter eminentemente repressivo, sem que se tenha a preocupação com um maior caráter pedagógico na sua realização, principalmente na gestão dos cartórios.

O controle preventivo de atos da Administração da Justiça Catarinense, por meio de auditoria operacional, resulta em melhoria de produtividade e, consequentemente, na busca pela efetividade da garantia de eficiência no acesso à justiça?

Desta forma, a indagação é se a revisão da postura da Administração do Judiciário em controle operacional interferirá de alguma forma, positivamente, no acesso à justiça, no sentido pleno de sua percepção, garantido constitucionalmente.

O método a ser utilizado no presente trabalho será o dedutivo ${ }^{1}$, posto que a investigação acerca do tema inicialmente está calcada em um estudo geral sobre a eficiência, como garantia de boa gestão, e controle da Administração Pública até chegar-se ao enfoque particular, o qual trata do estudo do controle dos atos dos Cartórios Judiciais Catarinenses, por meio de auditoria operacional.

O objetivo é a definição de um método diferenciado para o controle preventivo dos atos de gestão do Cartório do judiciário Catarinense, sem olvidar dos objetivos primordiais fixados na Constituição e, consequentemente, promover, de algum modo, efetivação do acesso à justiça.

O tema proposto é relevante pois abrange desde atos simples, necessários para a condução da atividade administrativa, a resultados de produtividade e celeridade processual que refletirão, de forma significante e repetitiva, na Administração da Justiça e, consequentemente, nos anseios da sociedade com relação a esse Poder.

Há necessidade de se ponderar e analisar as formas atuais de correições com o objetivo de adequar a realidade do Judiciário Catarinense às possibilidades de gestão e controles

\footnotetext{
1 "O raciocínio dedutivo fundamenta-se em um silogismo, uma operação típica da Lógica em que, a partir de uma premissa maior e mais genérica e uma menor e mais específica, pode-se chegar a um resultado necessário que é a conclusão.” (MEZZAROBA; MONTEIRO, 2014, p. 100)
} 
existentes, visando transformar paradigmas fortemente presentes no controle da Administração da Justiça, tornando- a mais dinâmica e eficaz.

Ressalta-se que essa pesquisa não visa esgotar o tema sugerido, mas ponderar objetivamente os aspectos que o envolvem, buscando propor soluções viáveis à problemática proposta de forma razoável e de acordo com o ordenamento jurídico brasileiro.

\section{Controle interno da administração pública}

O controle da Administração Pública, apesar de ser mais popular no aspecto da vigilância, é primordial para garantir que diretrizes resultantes das verificações existentes possam ser utilizadas como formas de melhorias.

Assim, esse mecanismo possui a função de vigilância das atuações administrativas, de guia para estabelecer diretrizes na condução das atividades e de correção para revisar condutas que necessitam de retificação.

Desta forma, esse controle abrange desde questões fiscalizatórias a possibilidade de prevenção de atuações deficitárias, garantindo que a condução das atividades seja respaldada no interesse público (Irene Patricia Hohara 2017).

Esse formato de verificação pode ser interno, quando é realizado pela autotutela administrativa, ou externo, quando é efetivado por outros Poderes. Quando realizado por meio interno, ou seja, por meio da autotutela, é uma forma de controle de sua própria atividade, realizado de forma a corrigir e sanar possíveis erros ou, ainda, aprimorar a execução de determinadas atividades, objetivando que a gestão seja o mais efetiva e eficiente possível.

Descrevendo as formas possíveis de controle interno e suas aplicabilidades, Phillip Gil França (2016, p. 106) analisa as divergências de atuações:

\footnotetext{
Basicamente, a atividade de um sistema de controle interno funciona por intermédio de uma sinérgica ação de ouvidoria, auditoria e corregedoria administrativa logicamente, podendo existir atribuições e rótulos diferentes em cada unidade administrativa. Entretanto, a função de a) ouvir e processar o reclame, seja do cidadão ou da própria Administração (ouvidoria); b) de verificar constantemente a legalidade, eficiência, eficácia e efetividade da Administração (auditoria); e de c) identificar, processar e encaminhar a respectiva e proporcional correção de falhas do exercício administrativo (corregedoria) persiste em qualquer sistema de controle interno.
}

As inspeções na Administração Pública podem ter grande impacto nos resultados e objetivos a serem alcançados pela mesma, uma vez que a utilização preventiva de diretrizes, pode abordar a execução de atos de forma mais eficaz, observando as normas existentes. 
Partindo para uma premissa mais gerencial, os ensinamentos acerca de políticas de gestão discorrem acerca da necessidade de realização de controles para que se possa alcançar os objetivos definidos pela Instituição. Nesse sentido, destaca-se o exposto por Clezio Saldanha dos Santos (2014, p. 111):

A finalidade do controle é assegurar que os resultados dos planejamentos e de suas execuções, observem as regras e ditames, bem como se aproximem o máximo possível do objetivo almejado.

Assim, uma boa Administração Pública requer a realização de controle de suas gestões para que se possa apontar os pontos de melhorias e se antecipar aos erros. O controle preventivo de gestão pode apontar gargalos, sanar erros operacionais e buscar alternativas mais eficientes para a condução das atividades.

Aspecto importante a ser destacado é que ainda que dentro da gestão exista discricionariedade, que é uma ferramenta essencial para que o administrador possa conduzir a atuação administrativa, existem limites que devem ser respeitados, sendo que esses também serão observados por meio de controle.

Atinente ao poder discricionário e à análise do mérito do ato administrativo, cabe destacar a afirmativa de Luiz Henrique Urquhart Cademartori (2017, p. 230):

Conclui-se que o mérito do ato administrativo é visto como uma liberdade mitigada, entretanto, não se trata de liberdade, mas do dever de avaliar. A análise do mérito, no exercício do poder discricionário, não está ligada a ideia de liberdade, pois a tarefa do administrador é encontrar a única solução adequada para o caso. Sendo possível avaliar dentre um leque de possibilidades, o gestor público deverá realizar a escolha da melhor solução, dentre aquelas igualmente possíveis.

O controle da Administração Pública representa um sistema de ferramentas que auxiliam na fiscalização, orientação e correção das atividades administrativas, visando sempre o cumprimento das normas legais, bem como do interesse público que deve estar presente em qualquer ação do Estado. (NOHARA, 2017, p. 889).

Esse mecanismo de gestão pode ter além do caráter de correção, o aspecto pedagógico, promovendo o melhor desempenho dos atos da Administração Pública, sendo imprescindível para que se promova a eficiência no modo previsto na Constituição. 


\section{Controle nos cartórios do judiciário catarinense}

No que concerne ao objeto da presente pesquisa, cumpre destacar a forma de organização do Poder Judiciário, mais especificamente a Corte Estadual Catarinense, para que possa se esclarecer a forma de controle dentro da Instituição.

Nessa linha, os cartórios judiciais são integrantes da estrutura dos órgãos auxiliares do juízo para condução na tramitação e cumprimento dos atos processuais e, por conseguinte, na concretização da prestação jurisdicional almejada. A previsão desse instituto está no artigo 95 da Constituição Federal e 77 da Constituição Estadual de Santa Catarina, que dispõem sobre a competência dos tribunais para organizar suas secretarias e serviços auxiliares do juízo.

Ainda que se trate de atividade meio, os cartórios têm papel fundamental na consecução da celeridade processual, uma vez que todo o tempo de percurso da tramitação do processo engloba os atos para concretização das decisões judiciais proferidas.

A paralisação de processos no cartório judicial para execução de atos processuais necessários para o regular prosseguimento dos processos tem por consequência o atraso da prestação jurisdicional na sua atividade fim.

Deve-se ponderar que para cada decisão proferida em um processo, em regra, há a necessidade de execução de atos pelo Cartório Judicial, e, se para cada uma dessas atividades houver um atraso significante, a tramitação de cada lide estará extremamente prejudicada.

Atendo-se que o planejamento e gestão abrangem atividades de controle, uma vez que tão imprescindível quanto planejar é a análise dos resultados, é importante que se realize uma maior fiscalização do exercício das atividades desenvolvidas nos cartórios judiciais para que se possa alcançar uma prestação jurisdicional célere e eficaz.

O Judiciário Estadual Catarinense utiliza o controle dos atos dos Cartórios por meio das Inspeções Judiciais, previstos no Código de Normas da Corregedoria-Geral da Justiça do Estado de Santa Catarina, bem como no Manual de Inspeção Judicial da Corregedoria-Geral da Justiça de Santa Catarina.

O Código de Normas da Corregedoria-Geral da Justiça do Estado de Santa Catarina (2013) dispõe acerca da função correicional, destacando-se: 
Art. $5^{\circ}$ A fiscalização dos juízos vinculadas ao primeiro grau de jurisdição e dos serviços auxiliares, das serventias notariais e de registro dar-se-á por intermédio de correição e controle do cumprimento de atos e procedimentos.

[...]

Art. 17. Os controles correicionais serão realizados por meio de sistemas de aferição da produtividade do juiz, do desempenho das varas e dos serviços judiciários, com base na análise estatística dos dados captados pela Corregedoria-Geral da Justiça. [...]

Art. 20. As aferições de desempenho das varas e dos serviços judiciários observarão os critérios fixados em ato administrativo do Corregedor-Geral da Justiça.

De igual forma, o Manual de Inspeção Judicial da Corregedoria-Geral da Justiça de Santa Catarina possui orientações acerca dos objetivos da realização dessa atividade, desses apontamentos ressalta-se:

A Corregedoria-Geral da Justiça de Santa Catarina tem como objetivo orientar, apoiar e fiscalizar a atividade judicial na busca permanente no aprimoramento e da efetividade da prestação jurisdicional.

As correições ordinárias realizadas por este órgão visam ao controle e à fiscalização dos serviços forenses, com destaque para a aferição do uso do SAJ, da capacitação dos servidores e do desempenho das unidades judiciárias. Algumas vezes, falhas no lançamento no sistema ou falhas na utilização de ferramentas de controle não refletem a qualidade do trabalho realizado. Por isso a atividade correicional é necessária.

Na mesma senda, a Resolução n. 47 GP de 1 de dezembro de 2015, institui o Manual de Auditoria Interna do Poder Judiciário do Estado de Santa Catarina, diante da necessidade de padronizar e buscar excelência nos métodos, critérios, conceitos e sistemas utilizados na atividade de auditoria, estabelecendo algumas diretrizes e visando aprimorar os procedimentos de realização de auditorias.

Entretanto, a Resolução supracitada, apesar das especificações acima, se limita ao controle das atividades das unidades administrativas, assim definido nas descrições de sua competência, bem como nas suas considerações finais.

Existem duas modalidades de correições utilizadas pelo Poder Judiciário Catarinense, o virtual e presencial. Nos dois casos são extraídos os relatórios dos dados e números da Unidade que são encaminhados para regularização pelo Cartório e Gabinete respectivo, sendo que no modo presencial ocorre uma visita da equipe da corregedoria para verificação de amostragem de processos, acolhimento de impressões e realização de entrevistas.

Em geral, os relatórios das inspeções correicionais dizem respeito à falta de impulso de autos, à correção de número de processos em andamento da Unidade e de atividades com execuções pendentes. 
Com caráter exemplificativo, colaciona-se postulados do Regulamento Geral da Corregedoria Nacional de Justiça, vinculada ao Conselho Nacional de Justiça, que menciona que a Inspeção possui, entre outros, o objetivo de aprimoramento de serviços, bem como que seu relatório apresentará recomendações de melhoria, nos seguintes termos:

Art. 45. A inspeção destina-se à verificação in loco de fatos que interessem a instrução de processos em tramitação na Corregedoria Nacional de Justiça ou no Conselho Nacional de Justiça, bem como da situação de funcionamento dos órgãos jurisdicionais de primeiro ou segundo grau, serviços auxiliares, serventias, órgãos prestadores de serviços notariais e de registro, objetivando o aprimoramento dos seus serviços, havendo ou não irregularidades.

$[\ldots]$

Art. 58. O relatório da inspeção conterá: a) a indicação e descrição das irregularidades encontradas e as respectivas explicações ou esclarecimentos prestados pelos magistrados ou servidores; b) as conclusões e as recomendações do Corregedor para prevenir erros ou aperfeiçoar o serviço naquela unidade judiciária; c) as reclamações recebidas contra a secretaria do órgão ou magistrado durante a inspeção ou que tramitem na Corregedoria-Geral; d) as boas práticas encontradas e que sejam passíveis de divulgação; e) a manifestação e apreciação conclusiva do Corregedor sobre todas essas questões, bem assim as determinações a serem cumpridas mediante prazo pelas autoridades e órgãos inspecionados.

Apesar de o dispositivo da Inspeção realizada pelo Conselho Nacional de Justiça possuir abertura para seu formato, o método utilizado no Tribunal de Justiça de Santa Catarina em São José no ano de 2013 consistiu no mesmo formato utilizado nas Inspeções da Corregedoria-Geral do Judiciário Catarinense, utilizando-se de coletas de dados e entrevistas para tanto.

Esses modelos de inspeções judiciais, apesar de produzirem resultados importantes, são formas paliativas de se buscar o aprimoramento supracitado, uma vez que não definem ou exemplificam formas possíveis de condução das atividades, com capacitação e demonstração necessárias para o aprendizado, limitando-se a apontar os erros encontrados e cobrar soluções, que algumas vezes, não são encontradas por falta de conhecimento ou experiências de seus gestores.

\section{A garantia de eficiência}

A garantia de eficiência é postulado que direciona e orienta as ações da Administração Pública para a consecução de seus objetivos previstos na Constituição Federal, guiando a conduta para o melhor aproveitamento dos atos possível.

A previsão legal da eficiência está na Constituição da República Federativa do Brasil (1988), no artigo 37 que afirma: “A administração pública direta e indireta de qualquer dos 
Poderes da União, dos Estados, do Distrito Federal e dos Municípios obedecerá aos princípios de legalidade, impessoalidade, moralidade, publicidade e eficiência e, também, ao seguinte:[...]".

De igual modo a Lei do processo administrativo federal — Lei n. 9.784, de 29 de janeiro de 1999, determina que os atos da Administração Pública devem ser regidos sob essa garantia:

Art. 2o A Administração Pública obedecerá, dentre outros, aos princípios da legalidade, finalidade, motivação, razoabilidade, proporcionalidade, moralidade, ampla defesa, contraditório, segurança jurídica, interesse público e eficiência.

Assim, nesse estudo será adotado o conceito de eficiência como garantia de uma boagestão e não como princípio, norma abstrata, garantia à boa administração pública, na qual a condução dos atos será norteada com probidade, motivação, transparência, e outras garantias que a englobam (Juarez Freitas, 2007).

A garantia de eficiência vincula-se ao modo de consolidação das ações, na qual a racionalidade deve ser preservada para que os atos sejam direcionados para a utilização das ferramentas e modos mais adequados, ponderando custo e tempo, e, assim, se alcance não somente os objetivos do ato em si como os objetivos precípuos da Administração Pública.

Apesar de ser citado por muitos autores como um princípio ligado à uma boa e desejável administração pública, o conceito de eficiência nesse ramo é um pouco mais limitado. Assim, Irene Patrícia Nohara (2017, p. 92 e 93) assim discorre:

\footnotetext{
A eficiência impõe ao agente público um modo de atuar que produza resultados favoráveis à consecução dos fins que cabe ao Estado alcançar.

$[\ldots]$

Note-se que a ideia de eficiência administrativa não deve se pautar apenas no aproveitamento de meios e recursos colocados à disposição dos agentes públicos; deve também abranger a relação dos meios utilizados e dos resultados obtidos em face das necessidades públicas existentes.
}

Ocorre que a eficiência presente na administração privada não pode ser equiparada para a administração pública, pois enquanto àquela objetiva lucro e buscam adequação às exigências do mercado, o Estado se preocupa com a consecução dos interesses públicos e com a prestação de serviços.

Dissertando sobre a diferença da eficiência da Administração Pública e da Administração Privada, Onofre Alves Batista Júnior (2012, p. 164) explana que a última se 
impulsiona pelo lucro, enquanto na esfera pública há uma maior complexidade, uma vez que suas referências não são mensuráveis e coloca à disposição das pessoas, também, bens imateriais o que acarreta maiores dificuldades de planejamento, execução e controle.

Por conseguinte, não se pode olvidar que na Administração Pública além dos elementos presentes na eficiência do setor privado, essa garantia deve se pautar, ainda, pelo respeito aos limites legais e interesse público.

Irene Patrícia Nohara (2017) explicita a divergência da eficiência aplicada na administração privada para administração pública. Esses dois tipos de administração divergem quanto à sua finalidade, uma vez que a administração privada visa o lucro, e a outra almeja a garantia do interesse público. Por conseguinte, a eficiência na Administração Pública está pautada em objetivos e limites diferentes, uma vez que o Estado objetiva sempre o interesse público, ainda que possa ser mais custoso e, deve observar os limites legais para execução de suas atividades.

O conceito de eficiência adotado no presente artigo é no sentido de garantia que impõe que a atuação administrativa seja conduzida para obtenção dos melhores resultados possíveis convergindo com os fins do Estado, abrangendo desde a melhor aplicação dos recursos à escolha dos meios utilizados para tanto.

Irene Patrícia Nohara (2012, p. 217) disserta sobre os limites da razoabilidade de eficiência no setor público, afirma que a eficiência no Poder Público não é uma exigência de perfeição, uma vez que existem limites para a atuação administrativa. Assim, a autora afirma que não é válido invalidar atos razoáveis sob a perspectiva que não alcançaram o esmero, pois a execução dos atos na Administração Pública pauta-se em limitações de recursos financeiros e humanos, por exemplo.

Não se trata de conceito ideal de objetivação da perfeição, mas de esmero na condução da atividade administrativa para que se possa concretizar os objetivos delimitados da melhor forma possível, acautelando-se de aspectos como economia, qualidade, celeridade, entre outros, sem olvidar as normas legais e o interesse público.

Por oportuno, destaca-se, ainda, a crítica do autor Celso Antônio Bandeira de Mello (2009. p. 122) quanto à inserção da eficiência no rol de princípios da Administração Pública por acreditar que se trata de postulado essencial à conduta do administrador estando intrinsicamente ligado à atividade administrativa, nesse sentido o Autor explana: 
O fato é que o princípio da eficiência não parece ser mais que uma faceta de um princípio mais amplo já superiormente tratado, de há muito, no direito italiano: o princípio da boa administração. Este último significa, como resulta das lições de Guido Falzone, em desenvolver a atividade administrativa "do modo mais congruente, mais oportuno, e mais adequados a serem alcançados, graças à escolha dos meios e da ocasião de utilizá-los concebíveis como os mais idôneos para tanto.

Destaca-se, ainda, uma definição relevante para a presente pesquisa, qual seja, a diferenciação de eficiência e efetividade. A eficiência coaduna-se com o modo da conduta, com os meios utilizados, já a efetividade direciona-se para os resultados. Desta forma, para que os objetivos da Administração Pública sejam concretizados, é importante que a condução dos atos esteja pautado nesses elementos, modo e resultado, conforme elucida José dos Santos Carvalho Filho (2017).

Destarte, a gestão da Administração Pública ideal, deve ser precipuamente carreada pela efetividade, fins, e pela eficiência, meios, conforme suscintamente diferenciado por Julio Cesar Marcellino Junior (2016).

A eficiência, nos termos constitucionais, é a concretização da busca da boa Administração pelo Estado, respeitando os ditames legais, atendo-se às diferenças da sua aplicabilidade no setor privado e sempre visando o interesse público na condução das atividades da Administração Pública.

\section{Auditoria operacional}

O termo auditoria remete à ação da análise de uma realidade comparada a um modelo pré-estabelecido como ideal.

Nesse sentido, auditoria é a confrontação, de forma imparcial, entre o fato concreto e o desejado, para se se possa esboçar opiniões ou comentários sobre a situação específica. (ARAÚJO, 2008, p. 15).

Existem muitos modelos de auditoria, classificadas de acordo com o objetivo pretendido pela ação, com o formato utilizado, ou pelo agente, por exemplo. Destaca-se a auditoria governamental que é realizada por órgãos ou entidades da Administração direta ou indireta, diferentemente da privada. Na mesma linha, a auditoria interna é realizada por pessoas vinculadas à entidade auditada e a externa é realizada por profissionais sem vínculo com o ente objeto de análise.

Atinente à classificação que difere de acordo com o objetivo do trabalho pode-se destacar a financeira, que realiza a análise dos demonstrativos contábeis, a auditoria 
operacional, que objetiva avaliar o desempenho e eficácia das operações e métodos de administração e a auditoria integrada, que abrange as auditorias supracitadas e faz uma análise geral, incluindo a contábil, a legalidade dos atos e, ainda, de economicidade e eficiência.

A auditoria operacional consiste em exame objetivo que visa apresentar uma avaliação de desempenho e de gestão, proporcionando informações para melhorar a administração e gestão, englobando efetividade e resultados, economicidade e eficiência. (ARAÚJO, 2008, p. 25).

Esclarecendo objetivamente e delimitando o conceito de auditoria operacional, Inaldo da Paixão Santos Araújo (2008, p. 31) o define da seguinte forma:

A auditoria operacional ou performance audit,como a denominam os americanos, é a análise e a avaliação do desempenho de uma organização - no todo ou em partes-, objetivando formular que recomendações e comentários que contribuirão para melhorar os aspectos de economicidade, eficiência e eficácia.

Auditoria operacional é o conjunto de procedimentos aplicados, com base em normas profissionais, sobre qualquer processo administrativo com o objetivo de verificar se eles foram realizados em observância aos princípios da economicidade, da eficiência, da eficácia e da efetividade. [...]

Outra característica importante do tipo de auditoria em comento é que a revisão proposta visa à apresentação de recomendações para melhorar o desempenho e aumentar o êxito da organização. (HALLER, 1985, p. 150)

Atualmente as auditorias no Poder Judiciário Catarinense, especificamente aos Cartórios Judiciais, possuem aspecto mais repressivo e de verificação de adoção dos procedimentos em consonância com as normas legais existentes sem propor alterações de métodos que impactem em melhorias significativas, que é um dos objetivos da auditoria operacional proposta nessa pesquisa.

Esse formato de auditoria também possui outras denominações, tais como auditoria de otimização de recursos, ou auditoria de performance. A auditoria governamental citada por Maria da Glória Arras Peter é uma vertente de auditoria de gestão, voltada para o exame das atividades e dos resultados obtidos de acordo com a economicidade, efetividade e eficiência de recursos públicos. (PETER, 2014, p. 94).

A auditoria operacional está prevista no Manual de Auditoria Governamental da Organização Latino- Americana e do Caribe das Organizações Superiores de Auditoria; no Escritório de Accountability Governamental dos Estados Unidos, bem como no Manual de auditoria do Tribunal de Contas da União. 
O manual de auditoria Operacional do Tribunal de Contas da União de 2010 descreve a auditoria operacional da seguinte forma: "o exame independente e objetivo da economicidade, eficiência, eficácia e efetividade de organizações, programas e atividades governamentais, com a finalidade de promover o aperfeiçoamento da gestão pública”.

O guia supracitado descreve resumidamente as atividades atinentes a esse tipo de controle no seguinte formato:

\begin{abstract}
Sinteticamente, o ciclo de auditoria operacional se inicia com o processo de seleção dos temas. Após a definição de tema específico, deve-se proceder ao planejamento com vistas à elaboração do projeto de auditoria, que tem por finalidade detalhar os objetivos do trabalho, as questões a serem investigadas, os procedimentos a serem desenvolvidos e os resultados esperados com a realização da auditoria. Na fase de execução, realiza-se a coleta e análise das informações que subsidiarão o relatório destinado a comunicar os achados e as conclusões da auditoria. A etapa de monitoramento destina-se a acompanhar as providências adotadas pelo auditado em resposta às recomendações e determinações exaradas pelo TCU, assim como aferir o benefício decorrente de sua implementação (ISSAI 3000/3.1, 2004; TCU, 2005).
\end{abstract}

Esse tipo de instrumento possui maior flexibilidade, contendo uma fase de coleta de dados e observação da forma de execução das atividades o que o diferencia dos métodos que se limitam à análise de resultados, que possuem limitações na produção de relatório que apenas aponta o erro e não sugere novas formas de procedimentos mais eficazes.

Existem diferentes formas de coleta de dados para auditoria, o Manual do Tribunal de Constas da União (2010, p. 63 e 64) elenca algumas opções, quais sejam, por questionários, entrevistas, observação direta e uso de dados existentes.

A forma de coleta de dados por meio de observação direta pode ser explorada de maneira mais ampla nesse tipo de auditoria, uma vez que consiste no registro presencial e sistemático de informações, por meio de um observador, permitindo ao observador compreender o contexto e que perceba aspectos que escapam ao participante, fornecendo uma visão mais ampla do objeto estudado. (TRIBUNAL DE CONTA DA UNIÃO, 2010, p. 64).

Destarte, a auditoria operacional é uma forma de controle flexível, amplo e que possui a finalidade de avaliar atos de gestão visando à melhoria de desempenho, especificamente na economicidade eficácia e eficiência.

\title{
6. Efetividade da eficiência em auditoria operacional no cartório judicial catarinense
}

Diante das inspeções correicionais com caráter eminentemente repressivo no Judiciário Catarinense, surge a proposta do presente estudo, qual seja, a implementação de 
auditoria operacional a ser realizada por servidor que tenha experiência na gestão cartorária, observando às peculiaridades do setor e apontando questões de ordem processual e gerencial que prescindam de modificação para condução das atividades e que acarretem mudança significativa, a longo prazo, nos resultados de desempenho dos Cartórios.

A realização dessa auditoria operacional deve ocorrer com a coleta de dados por meio de entrevistas, análise de números e, principalmente, por meio de observação direta, promovendo avaliação dos métodos, quantidade e divisão de trabalho, e, em um segundo momento, o repasse de recomendações que possam acarretar em melhorias de gestão administrativa e processual da unidade.

Por conseguinte, para que se possa aprimorar o conhecimento prático na execução das atividades dos gestores dos cartórios judiciais, o formato de imersão de pessoa que já tenha exercido essa atividade, como auditor e replicador de conhecimento, difunde o máximo de posturas produtivas e eficazes dentro do Poder Judiciário Catarinense.

A técnica da auditoria operacional é abrangente e flexível podendo ser abordada de acordo com a conveniência e oportunidade da Justiça Catarinense e utilizando-se, para tanto, as diretrizes do Manual do Tribunal de Constas da União.

Um excelente exemplo dessa necessidade de capacitação e aprendizagem da atividade laboral, desenvolvendo habilidades acerca das atividades específicas realizadas nos Cartórios Judiciais do Judiciário Catarinense, é a edição da Resolução CM n. 4, de 8 de junho de 2015, que regulamenta a necessidade de capacitação dos servidores que participam das correições nos cartórios judiciais por um período de 60 dias.

Assim, tão importante quanto a capacitação dos servidores que executam as atividades cartorárias, a capacitação do chefe de cartório que controla toda execução das atividades é primordial, sendo que um dos formatos possíveis desse auxilio é a colaboração de outro profissional, que tenha conhecimento para tanto, que poderá repassar conhecimentos adquiridos, analisar a realidade existente e apontar possíveis questões a serem melhoradas ou modificadas, não somente da questão gerencial, mas de todo trabalho exercido na Unidade, por meio de auditoria operacional com observação direta na coleta de dados.

O impacto da melhoria de gestão administrativa e processual pode ser sentido diretamente, na celeridade e qualidade dos atos processuais a serem realizados, e, consequentemente, na redução de processos, na agilidade da tramitação dos conflitos e, por conseguinte, na melhoria do acesso à justiça como um todo.

A necessidade de uma divulgação maior das experiências positivas dentro do Poder Judiciário por meio de auditoria operacional com utilização da observação direta pode apontar 
melhorias de gerenciamento administrativos e processuais das Unidades de forma antecipatória, ou seja, prevendo a possibilidade de aperfeiçoamento e abreviando erros, assim, garantindo que o acesso à justiça seja autêntico, eficiente e eficaz.

Com finalidade elucidativa, esclarece-se que atualmente, no Poder Judiciário Catarinense, a definição de método e organização das atividades entre os servidores, a eleição das formas de controle do andamento dos processos, o estabelecimento de planejamento e metas da Unidade, o controle das atividades exercidas, a eleição da metodologia de cumprimento dos processos urgentes e prioritários, a alimentação dos sistemas de dados do Conselho Nacional de Justiça, a busca por conhecimento de técnicas mais céleres e aproveitamento máximo dos sistemas e da força de trabalho existentes, são atividades exercidas pelo gestor da Unidade, com supervisão do magistrado, que impactam diretamente no andamento dos processos.

Apesar de existirem manuais cartorários e cursos de gestões, a carência está na falta de capacitações para os atuais gestores dos Cartórios Judiciais de forma em resultar na aplicação conjunta dos ensinamentos acerca da condução dos processos e dos conhecimentos de gestão de forma prática, observando às peculiaridades de cada Unidade, podendo acarretar impacto significativo nos resultados das tarefas desenvolvidas e, por consequência, no acesso à justiça.

Dados recentes de estudos acerca do Poder Judiciário demonstram o enorme crescimento de demandas não comportados pela estrutura atual das instituições. Desta forma, a utilização de mecanismos de controle e gestão são primordiais na busca da eficiência.

Atinente ao crescimento de demandas judicializadas, de acordo com o Relatório da Justiça em Números do Conselho Nacional de Justiça de 2017, o Poder Judicante finalizou o ano de 2016 com 79,7 milhões de processos em tramitação, com 29,4 milhões de novos processos, ou seja, um crescimento de 5,6\% em relação a 2015. Destacou, ainda, a taxa de congestionamento, com percentual de $73 \%$ em 2016, logo apenas $27 \%$ de todos os processos foram solucionados.

Exemplificando o impacto do crescimento em comento, no Relatório supracitado destacam-se dados acerca do custo de um processo, dividindo a soma das despesas do ano de 2016 pela quantidade de processos no Tribunal de Justiça de Santa Catarina, cada processo possuiu um custo de $\mathrm{R} \$ 435,99$ naquele ano. Ressalta-se que a Justiça Catarinense foi o $8^{\circ}$ Tribunal estadual com maiores despesas em 2016.

Esses dados demonstram a necessidade de adequação do Poder Judiciário ao crescente número de demandas, necessitando que se promovam medidas de otimização da prestação desse serviço. 
Elucida-se que a medida proposta no presente estudo foi aplicada por meio do Pedido de Providências n. 000305.91.2017.8.24.0600 da Corregedoria-Geral da Justiça de Santa Catarina, no qual houve requerimento da magistrada para disponibilização de assessor correicional para transmissão de conhecimento de organização e procedimentos cartorários em Unidade específica. Naquele momento houve a aplicação de auditoria operacional, com coleta de dados por meio de análise de números, entrevista e observação direta.

$\mathrm{Na}$ situação supracitada, após a apresentação de relatório de recomendações, houve melhora significativa dos números da Unidade, com redução do número de processos, redução de tempo e quantitativo de execução de atividades pendentes, bem como aumento significativo da produtividade dos servidores. Ressalta-se que foi mantido o número de servidores, bem como não foi realizado mutirão ou banco de horas para tanto, aproveitando-se apenas a estrutura existente. Destaca-se, ainda, que foram utilizados critérios de maneira fechada por se tratar de um objeto delimitado e o resultado é passível de alteração por outros fatores não contemplados.

O formato de Administração Pública preocupada com gestão pautada em eficiência, vai em contrapartida do modelo burocrático estatal, que sempre foi visto como impedimento para adequação a nova perspectiva da sociedade. O anseio social é cada vez maior do sentido de efetividade de ações públicas, com velocidade e qualidade na garantida dos direitos fundamentais (TRAMONTINI, 2015, p. 69).

Desta forma, a controle de atos dos Cartórios do Poder Judiciário Estadual de Santa Catarina pode ter grande impacto nos resultados e objetivos a serem alcançados pela Instituição e no acesso à justiça, uma vez que a utilização preventiva de diretrizes, pode abordar a execução de atividades de forma mais eficaz, observando as normas existentes, e, principalmente, utilizando-se práticas já testadas e produtivas, podendo garantir que a Administração buscará, de forma mais adequada, a eficiência garantida constitucionalmente.

\section{Conclusão}

A presente pesquisa envolve a tormentosa questão acerca da efetividade da garantia de eficiência do Poder Judiciário por meio de controle dos seus atos e as possíveis consequências dessa interferência no acesso à justiça.

O questionamento é se a realização de controle dos atos administrativos nos Cartório Judiciais da Justiça Catarinense, por meio de auditoria operacional com observação direta, pode acarretar em maior efetividade administrativa e processual da Unidade, proporcionando que o acesso à justiça seja garantido de forma mais eficaz, plena e célere. 
É notório uma crescente preocupação dos tribunais brasileiros com produtividade, celeridade e eficiência de suas gestões, entretanto ainda há um grande distanciamento da aplicação plena da garantia de eficiência da Administração Pública, prevista constitucionalmente, uma vez que a gestão e administração dos tribunais é realizada, algumas vezes, de forma ultrapassada.

Há necessidade de aprimoramento das inspeções judiciais internas realizadas pela Corregedoria-Geral de Justiça de Santa Catarina e a necessidade de uma divulgação maior das informações e experiências positivas dentro do Poder Judiciário, observando-se às peculiaridades de cada caso. A auditoria operacional com observação direta proporciona melhorias de gerenciamento administrativo e processual de forma antecipatória, ou seja, prevendo a possibilidade de aperfeiçoamentos não somente de formas repressivas.

A aplicação desse modelo de controle resulta em uma aplicação efetiva da garantia de eficiência, uma vez que visa antecipar soluções para problemas futuros, causando melhorias de gerenciamento administrativo e processual, e, por consequência, garantindo um acesso à justiça mais adequado, produtivo e célere.

\section{Referências bibliográficas}

ARAÚJO. Inaldo da Paixão Santos. Introdução à Auditoria Operacional. 4 ed. Rio de Janeiro: Editora FGV, 2008.

BARROSO, Luís Roberto. O Direito Constitucional e a Efetividade de suas Normas. 3 ed. Rio de Janeiro: Renovar, 1996.

BASTOS, Celso Ribeiro. Curso de Direito Administrativo. São Paulo: Celso Bastos Editora, 2002.

\section{BATISTA JÚNIOR, Onofre Alves Batista. Princípio Constitucional da Eficiência}

Administrativa. 2 ed. rev. e atual. Belo Horizonte: Fórum,2012.

BRASIL, Constituição da República Federativa do Brasil (1988). Emenda Constitucional n. 91, de .18 de fevereiro de 2016. Disponível em: $<<$ http://www.planalto. gov.br/ccivil_03/constituicao/constituicao.htm>. Acesso em: 08 ago.2017. 
BRASIL, Lei n. 9.784, de 29 de janeiro de 1999. Regula o Processo Administrativo no âmbito da Administração pública Federal. Disponível em: <http://wwwt.senado.gov.br/legbras/> . Acesso em 08 ago. 2017.

. Conselho Nacional de Justiça. Justiça em Números 2017. Disponível: < http://www.cnj.jus.br/files/conteudo/arquivo/2017/09/e5b5789fe59c137d43506b2e4ec4ed67. pdf $>$. Acesso em: 1 abr. 2018.

. Fundação Getúlio Vargas. Escola de Direito de São Paulo. Relatório ICJ Brasil $1^{\circ}$ Semestre de 2017. Disponível em <http://direitosp.fgv.br/sites/direitosp.fgv.br/files/ arquivos/relatorio_icj_1sem2017.pdf $>$ Acesso em 1 abr. 2018. Tribunal de Contas da União. Manual de auditoria operacional.-- 3.ed. Brasília : TCU, Secretaria de Fiscalização e Avaliação de Programas de Governo. (Seprog), 2010.

CADEMARTORI, Luiz Henrique Urquhart, Fernanda Santos Schramm. Direito Público e Hermenêutica: Problemas e desafios Atuais. 1 ed. Curitiba: Editora Prismas, 2017.

; DUARTE, Francisco Carlos Duarte. Hermenêutica e argumentação neoconstitucional. São Paulo: Atlas, 2009.

CARVAlHO FILHO, José dos Santos. Manual de Direito Administrativo. 31 ed. rev., atual. e ampl. São Paulo: Atlas, 2017..

DI PIETRO, Maria Sylvia Zanella. Direito Administrativo. 29 ed. São Paulo: Atlas, 2016.

FRANÇA, Phillip Gil. Controle da administração pública: combate à corrupção, discricionariedade administrativa e regulação econômica - 4. ed. rev., atual. e ampl. - São Paulo : Saraiva, 2016.

FREITAS, Juarez. O Controle dos Atos Administrativos e os Princípios Fundamentais. 2 ed. rev e atual. São Paulo: Malheiros, 1999. 
HALLER, Edward L. Avaliação de desempenho operacional - estabelecimento de uma auditoria operacional. EUA: Price Waterhouse, 1985.

LAMY, Eduardo de Avelar; RODRIGUES, Horácio Wanderlei. Teoria Geral do Processo. 4 ed.rev. e atual. São Paulo: Atlas, 2016.

MACIEIRA, Maria Elisa; Maranhão, Mauriti. Como implementar a gestão em Unidades Judiciárias. São Paulo: FGV, 2010.

MARCELLINO JÚNIOR, Julio Cesar. Análise Econômica do acesso á justiça: a tragèdia dos custos e a questão do acesso inautêntico. Rio de Janeiro: Lumen Juris, 2016.

MELLO, Celso Antônio Bandeira de. Curso de Direito Administrativo. 26 ed. rev., atual. e ampl. São Paulo: Malheiros, 2009.

MEZZAROBA, Orides; MONTEIRO, Cláudia Servilha. Manual de Metodologia da Pesquisa no Direito. 6 ed. São Paulo: Saraiva, 2014.

MORAES, Antonio Carlos Flores de. Legalidade, Eficiência e Controle da Administração Pública. Belo Horizone: Fórum, 2007.

NOHARA, Irene Patrícia. Direito Administrativo. 7 ed. rev.,atual, e ampl.-São Paulo: Atlas,2017.

. Reforma Administrativa e Burocracia: impacto da eficiência na configuração do direito administrativo brasileiro. São Paulo: Atlas, 2012.

PETER, Maria da Glória Arrais. Marcus Vinícius Veras Machado. Manual de auditoria governamental - 2. ed. - São Paulo: Atlas, 2014.

SANTA CATARINA. Código de Normas da Corregedoria- Geral da Justiça do Estado de Santa Catarina. 2013. 
. Constituição do Estado de Santa Catarina. Florianópolis. Imprensa Oficial. 1989.

Manual de Inspeção Judicial da Corregedoria-Geral da Justiça de Santa Catarina.

Manual de Auditoria Interna do Poder Judiciário do Estado de Santa Catarina

SANTOS, Clezio Saldanha dos Santos.Introdução à Gestão Pública. 2 ed. São Paulo:

Saraiva, 2014.

TRAMONTINI. Daine Sandra. Gestão da Administração Pública: uma reflexão das

relações entre os sujeitos e o Estado na garantia de direitos fundamentais. Direito, teorias e sistemas - Estudos desenvolvidos no programa de pós-graduação em direito da UFSC- Luiz Henrique Urquhart Cademartori; Sergio Ricardo Ferreira Mota (Orgs.). Florianópolis: Insular, 2015. 


\title{
INTERSETORIALIDADE E A TRANSVERSALIDADE DO DIREITO À SAÚDE
}

\author{
Adriano Tacca \\ FSG - Centro Universitário da Serra Gaúcha \\ Barbara Bedin \\ FSG - Centro Universitário da Serra Gaúcha
}

\section{Resumo}

A sociedade, na contemporaneidade, tem como característica ser diferenciada funcionalmente. Isso é resultado de um processo de evolução e especialização das comunicações internas da própria sociedade. A base teórica utilizada é a Teoria dos Sistemas Sociais de matriz Luhmanniana. O método é o dedutivo. Interessa-nos discutir de que de que forma a transversalidade e a intersetorialidade das ações de saúde podem contribuir para auxiliar os Sistemas Parciais da Sociedade na função de selecionar informações carregadas com fluxos comunicacionais de saúde que circulam pelo ambiente deste sistema e, de que forma, essa operação pode auxiliar na efetividade do direito à saúde.

Palavras-chave: intersetorialidade; transversalidade; direito à saúde, teoria sistêmica; gestão pública.

\section{Abstract/Resumen/Résumé}

Present society has the characteristic of being functionally differentiated. This is the result of an evolution and specialization process of internal communications within the society itself. The theoretical basis used is Luhmann's Systems Theory. The method is the deductive. We are interested in discussing how health actions' transversality and intersectoriality may contribute to help society's Partial Systems in the function of selecting information loaded with communicational health flows that circulate through the system's environment and, in which way this operation may contribute to the effectiveness of the right to health.

Keywords/Palabras-claves/Mots-clés: Intersectoriality, Transversality, Right to health, Systemic theory, Public administration. 


\section{Introdução}

No estágio atual, a sociedade apresenta-se em constante transformação. Ao analisá-la como um sistema social, encontramos a complexidade e a contingência como características intrínsecas desta sociedade. Luhmann1 foi um dos principais pesquisadores a realizar uma abordagem sistêmica do funcionamento da própria sociedade. Neste sentido, adota a complexidade e o processo evolutivo como ponto de partida de sua reflexão, isso, pois, "los sistemas median entre la escasa capacidad del hombre para elaborar sus vivencias conscientemente y la extrema complejidad del mundo" (LUHMANN, 2006. p. XI).

Ao longo dos tempos, a sociedade foi se especializando em comunicações, fato este que possibilitou o aprimoramento da própria sociedade e, com isso, tornou-se possível identificar diferenças entre os mais diversos sistemas parciais que a compõem.

A teoria sistêmica de matriz Luhmanniana procura explicar a sociedade como um Sistema Social (Vial, 2015). Para melhor compreensão, passaremos a identificar que a referida sociedade é composta por Sistemas Parciais, dentre eles, o Sistema Parcial da Política, do Direito, da Economia, da Saúde, dentre outros.

Ao fundamentarmos o raciocínio utilizando a matriz Luhmanniana é possível analisar a realidade social e suas transformações levando-se em conta a construção de comunicações diante de uma conjuntura de uma sociedade complexa (Campilongo, 2011).

Isso, ocorre, pois, "não é possível nenhuma produção de identidade, nenhuma produção de linguagem, que não seja no interior de uma sociedade. Tudo está dentro da sociedade" (ROCHA, 2009. p. 19). Para tanto, cada Sistema Parcial da sociedade atua com o seu código específico e binário em suas operações específicas de reprodução de comunicações.

Dessa forma, informações que circulam pelo ambiente da sociedade adquirem particular relevância quando possam irritar os Sistemas Parciais sensíveis ao tema da saúde.

Essa operação de irritação decorre de um processo interno e sistêmico de distinção/diferenciação. De fato, os fluxos comunicacionais em saúde exercem uma função essencial na irritabilidade dos Sistemas Parciais da sociedade dotados de condições para decidir (contribuir) a favor da efetivação do direito fundamental à saúde. 1 Uma compreensão mais aprofundada da Teoria Sistêmica de matriz Luhmanniana pode ser adquirida visitando-se as inúmeras obras do autor Niklas Luhmann. Dentre elas, sugerimos "La Sociedad de la Sociedad" e "Complejidad y Modernidad". Com esse propósito, o objetivo da pesquisa é investigar de que 
forma a intersetorialidade e a transversalidade das ações de saúde podem contribuir, ou mesmo, auxiliar os Sistemas Parciais da sociedade na função de filtrar ou selecionar informações carregadas com fluxos comunicacionais de saúde que circulam pelo ambiente do sistema e de que forma essa operação pode auxiliar na efetividade do Direito à Saúde. Isso se deve, em grande medida, pela análise da funcionalidade sistêmica que os Sistemas Parciais da sociedade operam, isso pois, eles podem se utilizar desses processos para a seletividade de expectativas atinentes ao direito fundamental à saúde dos cidadãos.

\section{Processos Intersetoriais e Transversais de Compartilhamento de Ações de Saúde com Vistas à Efetivação do Direito Fundamental à Saúde}

A gestão do Sistema Parcial da Saúde contempla um ambiente de elevada complexidade. Em vista disso, "não há como determinar o futuro; pode-se construí-lo encadeando ações orientadas por estratégias adequadas. Pensar o futuro é um exercício de lidar com a incerteza". As incertezas com relação ao tema da saúde geram o risco. Este risco é variável e depende da natureza da questão a ser abordada, uma vez que, para uma ação, surgem inúmeras possibilidades de intervenção, ou seja, podia ter sido decidido de forma diferente da que foi decidida.

Dificuldade semelhante, ou talvez ainda maior, deva ser aquela enfrentada pelo Sistema Parcial da Política, quando da pactuação desses interesses, ou das possibilidades de escolha da Política pública a ser executada. Para tal funcionalidade, esse Sistema Parcial da Sociedade necessita catalisar informações relevantes em matéria de saúde que estão presentes e circulam pelo ambiente da sociedade. Essas informações devem ser potencializadas, a fim de que possam ser compreendidas, posteriormente processadas no interior do referido Sistema Parcial da Política.

A Constituição Federal promulgada em 1988 deteve importante papel na (re)organização dessa funcionalidade do sistema, visto que previu a participação da comunidade no contexto da Saúde Pública brasileira. Essa garantia constitucional foi confirmada posteriormente com o advento da Lei 8.142/90². Com isso, esse Sistema Parcial da Sociedade passou a contar com duas instâncias colegiadas em cada esfera de governo

\footnotetext{
${ }^{1}$ BRASIL. Conselho Nacional de Secretários de Saúde. As conferências nacionais de saúde: evolução e perspectivas. Brasília, DF: CONASS, 2009. p. 35.

${ }^{2}$ Essa lei dispõe sobre a participação da comunidade na gestão do Sistema Único de Saúde (SUS) e sobre as transferências intergovernamentais de recursos financeiros na área da saúde e dá outras providências.
} 
(Conferências de Saúde e os Conselhos de Saúde). Essas estruturas têm, dentre outras atribuições, a função de catalisar informações presentes no ambiente, potencializar essas informações para que os sistemas parciais possam compreendê-las e processá-las, conforme seu código específico.

Na concepção de Correia $^{3}$, as Conferências de Saúde têm:

Cumprido o papel de divulgadoras de informações sobre a política de saúde entre a sociedade e os trabalhadores da saúde, ao mesmo tempo que, de certa forma, obrigam os gestores a escutar as avaliações e reclamações feitas pela sociedade sobre os serviços de saúde. Constituem-se em canais democráticos e participativos que, além de abrirem espaço para a avaliação, discussão e proposição, no âmbito local, por quem faz, administra e usa os serviços de saúde, permitem a articulação das questões locais com os determinantes gerais da política de saúde. Congregam forças em torno das propostas e lutas para o enfrentamento dos problemas estruturais e conjunturais do setor. (grifo nosso).

Como observado, cabe à Conferência de $\mathrm{Saúde}^{4}$ (convocada a cada quatro anos pelo Poder Executivo) informar ao sistema a situação da saúde daquele ente da Federação, além de abastecer o sistema com informações que permitam a ele definir as diretrizes para a formulação das políticas públicas de saúde em cada um desses níveis de governo para o quadriênio posterior. O Plano Plurianual anterior (União e Estados) compreendeu os anos de 2012 a 2015. O atual compreende 2016 a 2019. Visa o plano definir o conjunto das políticas públicas do governo (para quatro anos), e as estratégias para viabilizar as metas previstas. ${ }^{5}$

Para que essas ações sejam efetivadas, faz-se necessário observar o panorama demográfico da população brasileira. Nele, atingimos em agosto de 2010 a cifra de 190.732 .694 habitantes ${ }^{6}$. No comparativo com a última década, ocorreu um crescimento de $1,17 \%$ da população. Se comparado com os últimos trinta anos, é possível observar uma redução absoluta do número de nascimentos no país. Em contrapartida a esses dados, temos o fato de que os níveis elevados de fecundidade da década de setenta, foi responsável por um grande contingente

\footnotetext{
${ }^{3}$ CORREIA, Maria Valéria Costa. Que controle social? Os conselhos de saúde como instrumento. Rio de Janeiro: Fiocruz, 2000. p. 68.

${ }^{4}$ Durante o ano de 2015, foram realizadas Conferências Municipais de Saúde (CMS), aprovando as diretrizes para a área da saúde entre os anos 2016-2019 em todos os municípios brasileiros. Posteriormente, cada um dos estados brasileiros convocaram os municípios de sua jurisdição, a fim de aprovar as propostas de saúde para cada um dos estados nas Conferências Estaduais de Saúde (CES). Por fim, realizou-se de 01a 04 de dezembro de 2015 a $15^{\text {a }}$ Conferência Nacional de Saúde (CNS), qur definirá as prioridades da saúde para a agenda dos próximos quatro anos.

${ }^{5}$ BRASIL. Ministério do Planejamento Desenvolvimento e Gestão. O que é o PPA? Brasília, DF, 22 maio 2015. Disponível em: <http://www.planejamento.gov.br/servicos/faq/planejamento-governamental/plano-plurianual-ppa/oque-eacute-o-ppa>. Acesso em: 02 jun. 2016.

${ }^{6}$ Segundo o IBGE, a estimativa atual é de que a população brasileira seja supeior a 205.253.741 (duzentos e cinco milhões, duzentos e cinquenta e três mil, setecentos e quarenta e um habitantes). Calcula o Instituto que a cada 19 segundos uma pessoa é somada a esse número. INSTITUTO BRASILEIRO DE GEOGRAFIA E ESTATÍSTICA (IBGE). População do Brasil. Rio de Janeiro, 2015. Disponível em: <http://www.ibge. gov.br/apps/populacao/ projecao/>. Acesso em: 21 jan. 2016.
} 
de nascimentos, consequentemente, pelo estabelecimento de uma população predominantemente jovem. Outro aspecto a ser observado concerne ao contínuo aumento da expectativa de vida, hoje alcançando 73 anos de idade. Essa rápida transição demográfica será igualmente responsável por impactos importantes na área da saúde da população. Isso decorre, sobretudo, devido ao aumento de doenças crônicas não transmissíveis, mais frequentes em pessoas de idade avançada. ${ }^{7}$

Além disso, o Sistema Parcial da Saúde precisa avaliar os determinantes e condicionantes que interferem direta ou indiretamente nas condições de saúde da população. Dentre eles, podemos citar: os aspectos socioeconômicos; as condições de vida, trabalho e ambiente; os hábitos e estilos de vida; o complexo produtivo, de ciência, tecnologia e inovação em que os cidadãos estão inseridos. Além desses elementos, o Sistema Parcial da Saúde necessita avaliar a forma como a população tem acesso à saúde, melhor dizendo, os fatores relativos à atenção básica, especializada, de urgência, mental, farmacêutica, para a população indígena e vigilância sanitária. ${ }^{8}$

Para Dallari, ${ }^{9}$ é necessário

Concluir que saúde depende, ao mesmo tempo, de características individuais, físicas, psicológicas, mas, também, do ambiente social e econômico, tanto daquele mais próximo das pessoas, quanto daquele que condiciona a vida dos Estados. O que obriga afirmar que, sob a ótica jurídica, a saúde deverá inevitavelmente implicar aspectos individuais, sociais e de desenvolvimento.

Por esse olhar, podemos observar que a saúde comporta características de generalidade e abstração. Igualmente, podemos compreender que nos deparamos com um 'valor saúde'10, que tem pretensões abstratas e universais. Dessa forma, os conceitos, premissas, regras, ações devem ignorar as diferenças pontuais entre os elementos que compõem uma mesma categoria. Logo, os conceitos de saúde devem partir dos traços comuns a todos, embora seja impensável, igualmente, uma concepção de saúde que não olhe para uma dimensão coletiva. Esse paradoxo demonstra a impossibilidade de responsabilização individual pela efetividade da saúde. Isso

\footnotetext{
${ }^{7}$ BRASIL. Ministério da Saúde. Secretaria-Executiva. Subsecretaria de Planejamento e Orçamento. Plano Nacional de Saúde-PNS: 2012-2015. Brasília, DF, 2011. p. 13. Disponível em: <http://conselho.saúde.gov.br/biblioteca/ Relatorios/plano_nacional_saúde_2012_2015.pdf>. Acesso em: 21 jan. 2016.

${ }^{8}$ BRASIL. Ministério da Saúde. Secretaria-Executiva. Subsecretaria de Planejamento e Orçamento. Plano Nacional de Saúde-PNS: 2012-2015. Brasília, DF, 2011. p. 13. Disponível em: <http://conselho.saúde.gov.br/biblioteca/ Relatorios/plano_nacional_saúde_2012_2015.pdf>. Acesso em: 21 jan. 2016.

${ }^{9}$ DALLARI, Sueli Gandolfi; NUNES JŪNIOR, Vidal Serrano. Direito sanitário. São Paulo: Verbatim, 2010. p. 11.

${ }^{10}$ Vial, afirma que a saúde pode ser considerada um valor, uma vez que este tem sentido porque é indeterminado. VIAL, Sandra Regina Martini. Construção do sistema social da saúde a partir da teoria sistêmica de Niklas Luhmann. Revista de Direito Sanitário, São Paulo, v. 16, n. 1, mar.jun. 2015.
} 
ocorre, por exemplo, pelo fato de que o aparecimento de doenças possa estar ligado a fatores sociais, culturais, ou mesmo, políticos. ${ }^{11}$

De fato, é importante salientar "que a produção da saúde envolve a superação dos recortes setoriais tradicionais e exige resolver problemas complexos, multideterminados, com espacialidades distintas e que integram espaços de governabilidade externos ao setor" ${ }^{\text {" }}$. Além desses, outros fatores acrescentam mais dificuldade para que consigamos alcançar a saúde em sua plenitude, a exemplo, na contemporaneidade, a internacionalização da vida social é um dos fatores que contribui para esse desafio. Isso, pois o sujeito que é destinatário dos serviços de saúde, "não é mais apenas um indivíduo, ou um conjunto de indivíduos, mas todo um grupo humano ou a própria humanidade". ${ }^{13}$

Para melhor ilustrar essa nossa visão da saúde, é que citamos a importância dos mecanismos internacionais que fazem a proteção dessa rede de interesse que engloba a área da saúde. Nesse sentido, é que encontramos a Declaração de Doha (2001), o acordo TRIPS no que tange à Saúde Pública, a IV Conferência Ministerial da OMC. Essa última, por sua vez, trata de questões que envolvem as patentes de medicamentos e a necessidade de se interpretar o acordo TRIPS de forma a proteger a Saúde Pública, e a necessidade de incentivos para as pesquisas que envolvem os medicamentos necessários para cura de novas doenças, dentre elas a AIDS (uma vez que na época apresentava aspectos de pandemia).

Outro exemplo que demonstra os esforços conjuntos é a resolução WHA 58.3 da $58^{\mathrm{a}}$ Assembleia Mundial da Saúde. A referida resolução evidencia a complexidade do tema da saúde, de tal modo que passou a exigir uma criteriosa regulação das ações de vigilância em saúde no mundo. Em síntese, pode-se verificar que a globalização da vida social exerce e exercerá influência constitutiva no conceito de saúde.

Como se percebe, os problemas que envolvem a saúde são muitos, de tal maneira refletindo a complexidade que os sistemas parciais da sociedade enfrentam. A proteção do direito à saúde, nesse sentido, faz com que o Sistema Parcial do Direito "apresente interfaces com diversos outros ramos do saber" 14 , ou seja, possa esse Sistema Parcial abrir-se para o ambiente, a fim de potencializar as informações que, posteriormente, serão processadas no interior do próprio sistema.

\footnotetext{
${ }^{11}$ DALLARI, Sueli Gandolfi; NUNES JUNIOR, Vidal Serrano. Direito sanitário. São Paulo: Verbatim, 2010. p. 12-13.

${ }^{12}$ BRASIL. Conselho Nacional de Secretários de Saúde. As conferências nacionais de saúde: Evolução e perspectivas. Brasília, DF: CONASS, 2009. p. 39.

${ }^{13}$ DALLARI, Sueli Gandolfi; NUNES JUNIOR, Vidal Serrano. Direito sanitário. São Paulo: Verbatim, 2010. p. 17-29.

${ }^{14}$ DALLARI, Sueli Gandolfi; NUNES JUNIOR, Vidal Serrano. Direito sanitário. São Paulo: Verbatim, 2010. p. 30.
} 
E isso é claro nos relatórios das conferências nacionais, em que se identificam inúmeras recomendações que implicam as ações de outras áreas setoriais relevantes para a produção ou promoção da saúde, prevenção de danos e doenças. Políticas de emprego, moradia, acesso à terra, saneamento e ambiente, saúde, educação, segurança pública, segurança alimentar e nutricional devem operar de forma integrada, em caráter permanente, em todas as esferas de governo, orientadas pelo objetivo de assegurar saúde. $^{15}$

No mesmo sentido, encontramos assinalado no relatório da $12^{\mathrm{a}}$ Conferência de Saúde que entre "os profissionais de saúde já existe a consciência de que seus saberes e sua atuação setorial são insuficientes para alcançar resultados efetivos e transformadores para problemas complexos e para promover a qualidade de vida da população"16. Sem embargo, refere ainda o relatório que o caminho a ser percorrido nesse sentido é longo, tanto no plano dos saberes técnicos, científicos como no plano das ações práticas.

Por essa razão que afirmamos não haver mais espaço para concepção de ações de saúde localizadas, sendo, portanto, preciso uma atuação intersetorial, transversal do tema. Além disso, Marques $^{17}$ aponta como importante, a dimensão dessa intersetorialidade e transversalidade, bem como a forma como os sistemas parciais da sociedade funcionam, e da necessidade de cada sistema em aumentar a complexidade interna, para que de forma paradoxal possa diminuí-la. Nessa mesma linha de raciocínio, é visível a necessidade de criarem-se novos canais comunicativos entre os sistemas parciais, a fim de que as comunicações possam alimentar esses sistemas.

Para Gallo ${ }^{18}$, outro desafio dos sistemas parciais da sociedade é:

Inserir-se em uma agenda intersetorial e interescolar que enfrente seus determinantes sociais em um processo de governança participativo, capaz de construir uma hierarquia de prioridades a partir das necessidades do território e de produzir soluções tecnopolíticas baseadas na ecologia dos saberes, constituindo um processo de gestão estratégico situacional e comunicativo. ${ }^{19}$

Para tal desafio, o Sistema Parcial da Política deve organizar as propostas de políticas públicas, a fim de tentar resolver o binômio que circunda a saúde/doença. Com esse desígnio,

\footnotetext{
${ }^{15}$ BRASIL. Conselho Nacional de Secretários de Saúde. As conferências nacionais de saúde: Evolução e perspectivas. Brasília, DF: CONASS, 2009. p. 39.

${ }^{16}$ CONFERÊNCIA NACIONAL DE SAÚDE, 12., 2003, Brasília, DF. Relatório final. Brasília, DF: Ministério da Saúde, 2004. p. 44. Disponível em: $<$ http://conselho.saúde.gov.br/biblioteca/Relatorios/relatorio_12.pdf $>$. Acesso em: 15 jun. 2016.

${ }^{17}$ MARQUES, Silvia Badim. Direito à saúde: complexidade e enfrentamentos extrajudiciais. Brasília, DF: CONASS. 2015. p. 4. (Para entender o SUS).

${ }^{18}$ GALLO, Edmundo; SETTI, Andreia Faraoni Freitas. Território, intersetorialidade e escalas: requisitos para a efetivação dos objetivos de Desenvolvimento Sustentavel. Ciência Saúde Coletiva, Rio de Janeiro, v. 19, n. 11, p. 4383, nov. 2014. Disponível em: <http://www.scielo.br/pdf/csc/v19n11/1413-8123-csc-19-11-4383.pdf>. Acesso em: 21 jan. 2016.

${ }^{19}$ Para o autor, a expressão 'interescalar' refere que a saúde deve ser pensada do local para o global.
} 
o Plano Nacional de Saúde (2012-2015) prevê quatorze diretrizes a serem adotadas com fulcro na promoção e efetivação da Saúde Pública no Brasil. De tais diretrizes, destacamos duas que estão voltadas à transversalidade das ações de saúde. A primeira visa a implementar ações de saneamento básico e saúde ambiental, de forma sustentável, para a promoção da saúde e redução das desigualdades sociais, com ênfase no Programa de Aceleração do Crescimento. A segunda objetiva contribuir para a erradicar a extrema pobreza no país.

$\mathrm{Na}$ transversalidade, exige-se o envolvimento de todas as estruturas do Sistema Parcial da Política ${ }^{20}$. Para Vial ${ }^{21}$, será por esse novo caminho, melhor dizendo:

Em conjunto com as mais diversas áreas do conhecimento, que o direito moderno deve ser estudado, aplicado e refletido, e não apenas, como tradicionalmente vem ocorrendo, a partir da ótica dogmática e formalista. Estudar o Direito a partir de uma visão transdisciplinar implica construir um novo referencial para a própria ciência do Direito, o qual deve se fundamentar em outras áreas de estudos que estão intrinsecamente ligadas 'com' e 'nos' fenômenos sociojurídicos.

Como já afirmado, as expectativas que envolvem o direito à saúde são muitas. Idem se pode afirmar com relação às frustações geradas dessas expectativas. Os problemas de acesso e efetividade da saúde decorrem principalmente por fatores que envolvem as relações sociais, ou mesmo, o sistema socioeconômico da população. Nesse sentido, ainda há questões que envolvem o gênero, a raça, a etnia, a orientação sexual, dentre tantos outros motivos.

Devido à diversidade e heterogeidade da sociedade brasileira, impõe-se ao Sistema Parcial da Política a necessidade de se (re)organizar e pensar o novo (velho/novo ou ainda o novo/velho), para com isso tentar conseguir uma efetividade pretendida por meio das políticas públicas que envolvam a Saúde Pública; assim, possa superar as iniquidades a que a população é submetida. O enfrentamento das iniquidades na área da saúde demanda "ampla e sistemática articulação intersetorial (com vistas à implementação de políticas públicas integrada), assim como a participação da sociedade civil, de modo a contribuir de forma efetiva para a sua inclusão".22

Embora já afirmássemos que a descentralização é uma das possiblidades de alteração da gestão de uma Política Social, difícil, para não dizer quase impossível, que ela, por si só,

\footnotetext{
${ }^{20}$ BRASIL. Ministério da Saúde. Secretaria-Executiva. Subsecretaria de Planejamento e Orçamento. Plano Nacional de Saúde-PNS: 2012-2015. Brasília, DF, 2011. p. 68. Disponível em: <http://conselho.saúde.gov.br/biblioteca/ Relatorios/plano_nacional_saúde_2012_2015.pdf>. Acesso em: 21 jan. 2016.

${ }^{21}$ VIAL, Sandra Regina Martini. Direito fraterno na sociedade cosmopolita. Contribuciones desde Coatepec, Toluca, n. 12, p. 123-138, enero/jun. 2007. Disponível em: <http://www.redalyc.org/pdf/281/ 28101207.pdf $>$. Acesso em: 09 ago. 2016.

${ }^{22}$ BRASIL. Ministério da Saúde. Secretaria-Executiva. Subsecretaria de Planejamento e Orçamento. Plano Nacional de Saúde-PNS: 2012-2015. Brasília, DF, 2011. p. 40. Disponível em: <http://conselho.saúde.gov.br/biblioteca/ Relatorios/plano_nacional_saúde_2012_2015.pdf>. Acesso em: 21 jan. 2016.
} 
possa garantir a eficácia, ou mesmo, a efetivação da saúde, conforme as expectativas de todos os seus destinatários. Com efeito, uma política pública que busca a resolução de um problema de saúde precisa considerar a amplitude desse Sistema Parcial, ao contrário de vê-lo por uma plasticidade fragmentada. Essa dicotomia pode ser superada pela intersetorialidade (para além da saúde $^{23}$ ). Dessa forma, embora os problemas se manifestem de forma setorial, a solução desses depende da ação de mais de uma política pública, ou de políticas que transitem de forma intersetorial e transversal entre os setores envolvidos, uma vez que são partes de um todo complexo. $^{24}$

Mas, enfim, o que representa a intersetorialidade que estamos falando. Feuerwerker e $\operatorname{Costa}^{25}$ definem a intersetorialidade na área da saúde como sendo:

A articulação entre sujeitos de diferentes setores sociais diversos e, portanto, de saberes, poderes e vontades diversos, para enfrentar problemas complexos. É uma nova forma de trabalhar, de governar e de construir políticas públicas que pretende possibilitar a superação da fragmentação dos conhecimentos e das estruturas sociais para produzir efeitos mais significativos na saúde da população.

Vemos, na observação acima, que a Saúde Pública nessa nova fase de intersetorização, necessita estar em consonância com os diversos setores da sociedade. Essa nova articulação poderá irritar (potencializar informações) outros sistemas parciais da sociedade com novas informações (possibilidades), que podem advir de distintos setores presentes no ambiente da sociedade. Dessa forma, inserindo-se novos atores na discussão, o Sistema Parcial da Saúde passa a ser nutrido por outras possibilidades de consecução de seu desiderato.

Nessa nova perspectiva de atuação, o Sistema Parcial da Política busca um sentido de unidade na diversidade. Assim, os novos atores trazidos para o seio da discussão, visam a auxiliar esse Sistema Parcial a construir novas ações intersetoriais, que serão possíveis graças à soma das diferentes visões interdisciplinares que são lançadas sobre um mesmo objeto. Esses novos atores podem igualmente, questionar, ou sugerir estratégias usadas ou previstas para diferentes territórios e populações.

Em outras palavras, a prática da intersetorialidade possibilita aos sistemas parciais, que são sensíveis ao tema da saúde, responder às expectativas que são oriundas de diferentes

\footnotetext{
${ }^{23}$ GALLO, Edmundo; SETTI, Andreia Faraoni Freitas. Território, intersetorialidade e escalas: requisitos para a efetivação dos objetivos de Desenvolvimento Sustentavel. Ciência Saúde Coletiva, Rio de Janeiro, v. 19, n. 11, p. 4384, nov. 2014. Disponível em: <http://www.scielo.br/pdf/csc/v19n11/1413-8123-csc-19-11-4383.pdf>. Acesso em: 21 jan. 2016.

${ }^{24}$ JUNKEIRA, Luciano A. Prates. Descentralização e intersetorialidade. Revista Saúde e Sociedade, Sao Paulo, v. 6 , n. 2, p. 32, 1997.

${ }^{25}$ FEUERWERKER, L. M.; COSTA, H. Intersetorialidade na rede unida. Saúde em Debate, Rio de Janeiro, v. 22, p. $13,2000$.
} 
coletividades, uma vez que são ouvidas as expectativas dos destinatários das ações de saúde. Igualmente, abre-se espaço para a autonomia descentralizada das estruturas do Sistema Parcial da Política sem deixar desqualificada a centralidade do papel do Estado na formulação e qualificação das propostas que envolvem a Saúde Pública. ${ }^{26}$

Na legislação pátria, podemos observar inúmeros exemplos de intersetorialidade. Para melhor visualizar o que estamos afirmando, citamos a legislação contra o fumo em locais públicos, na obrigatoriedade do uso do cinto de segurança e, ainda, na legislação que prevê o controle de velocidade dos veículos que circulam pelas vias públicas, dentre tantas outras. ${ }^{27}$ Como vemos, as legislações mencionadas buscam a proteção ao bem saúde de forma intersetorial, uma vez que tratam da saúde de forma transversa, ou seja, não é o objeto único da legislação.

Ainda nessa linha de raciocínio, analisamos o Programa Saúde na Escola (Decreto Presidencial 6.286/07). Esse programa governamental propunha uma política intersetorial entre os Ministérios da Saúde e da Educação. Além desse, outro exemplo de intersetorialidade que envolve o setor da saúde visualizado, quando analisamos o lançamento (2009) do Plano Emergencial de Ampliação do Acesso ao Tratamento e Prevenção em Álcool e outras Drogas (PEAD).

Esse plano potencializou a implantação de Centros de Atenção Psicossocial Álcool e Drogas - CAPSad, de leitos hospitalares e de estratégias de articulação intersetorial. Estimulou também a criação dos consultórios de rua, com o objetivo de atender demandas de populações sem domicílio, que usam crack. $^{28}$

Como bem podemos observar, o Sistema Parcial da Política (re)organizou suas ações de forma intersetorial, a fim de enfrentar essa questão complexa que envolve a Saúde Pública (uso de drogas lícitas ou não). Nesse exemplo, por sorte, esse Sistema Parcial da Sociedade foi sensível em compreender a importância, por não dizer, as vantagens da utilização da intersetorialidade das políticas públicas para esse setor.

Acrescenta-se que esse plano de caráter intersetorial de enfrentamento às drogas consiste em aprofundar as ações em desenvolvimento, aliando-as a outras ações que porventura possam auxiliá-lo nessa missão. Imbuído desse propósito é que foram criados os CAPS 24

\footnotetext{
${ }^{26}$ AZEVEDO, Elaine de. PELICIONI, Maria Cecilia Focesi. WESTPHAL, Marcia Faria. Práticas intersetoriais nas políticas. Physis Revista de Saúde Coletiva, Rio de Janeiro, v. 22, n. 4, p. 1335, 2012.

${ }^{27}$ PAIM, Jairnilson Silva. O que é SUS. Rio de Janeiro: Fiocruz, 2009. p. 16-41.

${ }^{28}$ BRASIL. Ministério da Saúde. Secretaria-Executiva. Subsecretaria de Planejamento e Orçamento. Plano Nacional de Saúde-PNS: 2012-2015. Brasília, DF, 2011. p. 49. Disponível em: <http://conselho.saúde.gov.br/biblioteca/ Relatorios/plano_nacional_saúde_2012_2015.pdf>. Acesso em: 21 jan. 2016.
} 
horas; as casas de acolhimento transitório; a habilitação e financiamento diferenciado para leitos em hospitais gerais; o apoio a comunidades terapêuticas, e os centros regionais de referência para a formação de profissionais de saúde.

Como se percebe, para que o Sistema Parcial da Política dê efetividade à saúde, fez-se necessário que ele se utilizasse das ações intersetoriais a serem comandadas pelo Ministério da Saúde. Nesse sentido, salientamos que o referido Sistema Parcial da Sociedade foi sensível em perceber a importância da intersetorialidade de suas ações com fulcro em tentar alcançar seus objetivos. Essa necessidade de (re)organização é devida, em grande face, às transformações em curso na sociedade contemporânea, uma vez que essa contempla alta complexidade, e o cenário de expectativas versus desilusões dos cidadãos mostra-se desafiador.

É com esse objetivo que o sistema implanta em 2009 uma "Rede de Produção de Saúde" ${ }^{29}$. Essa política pública oriunda do Sistema Parcial da Política reafirma que o sistema compreendeu a necessidade de suas ações integrarem um conjunto de atos que englobem diversos órgãos e diferentes áreas do conhecimento, com vistas a construir um sistema de saúde integrado, compartilhado e corresponsável, dessa forma, procurando evitar a sobreposição de ações e concorrência de recursos.

Esse intuito do sistema em promover ações compartilhadas e intersetoriais pode ser verificado na legislação mais recente que interessa ao tema. Como exemplo, citamos a portaria de n. ${ }^{\circ}$ 2.446, de 11 de novembro de 2014. Nela, a Política Nacional de Promoção da Saúde (PNPS) passa a ser definida com base num novo conceito ampliado em saúde, que, somado ao novo referencial teórico da promoção da saúde, visa a definir um conjunto de estratégias e formas de produzir saúde tanto no âmbito individual como no coletivo. A referida legislação busca ainda promover e efetivar a saúde por meio da intersetorialidade. Esta compreende um processo de articulação de saberes, potencialidades e experiências de sujeitos, grupos e setores na construção de intervenções compartilhadas, estabelecendo vínculos, corresponsabilidade e cogestão para objetivos comuns. Alia-se a isso a articulação com as demais redes de proteção social, participação e controle social. ${ }^{30}$

Salienta-se que embora o território das ações intersetoriais passe a ser aquele onde as ações ocorrem de forma concreta, melhor dizendo, onde as práticas são realizadas no mundo

\footnotetext{
${ }^{29}$ BRASIL. Ministério da Saúde. Secretaria de Atenção à Saúde. Política Nacional de Humanização da Atenção e Gestão do SUS. Redes de produção de saúde. 1. ed. Brasília, DF: Ministério da Saúde, 2010. (Série B. Textos Básicos de Saúde). Disponível em: <http://www.redehumanizasus.net/sites/default/files/itens-do-acervo/files/ redes_de_producao_de_saude.pdf $>$. Acesso em: 21 jan. 2016.

${ }^{30}$ Vide portaria de $\bar{n}^{\circ}{ }^{2} .446$ de 11 de novembro de 2014. BRASIL. Ministério da Saúde. Portaria n. ${ }^{\circ} 2.446$ de 11 de novembro de 2014. Redifine a política Nacional de Promoção da Saúde (PNPS). Disponível em: <http://bvsms. saude.gov.br/bvs/saudelegis/gm/2014/prt2446_11_11_2014.html>. Acesso em: 02 jun. 2016.
} 
dos fatos, isso não implica afirmar que toda e qualquer intersetorialização deva abdicar de recortes específicos de cada área ou Política, ou ainda, dizer a ação originária de uma área é mais importante, ou mesmo, mais relevante que as outras áreas. Dessa forma, "problemas e desafios são produzidos em redes complexas e, por essa razão, reclamam compreensões ampliadas e intervenção intersetoriais, articulando distintos territórios de saberes e práticas". ${ }^{31}$

Nesse sentido, a intersetorialidade deve:

Traduzir e atender a princípios e modos de operar no conjunto das relações entre profissionais e usuários, entre diferentes profissionais, entre diversas Unidades e serviços de Saúde, entre instâcias que constituem o SUS. O confronto de ideias, o planejamento, os mecanismos de decisão, as estratégias de implementação e de avaliação, mas principalmente o modo como tais processos se dão, devem confluir na construção de trocas solidárias e comprometidas com a produção de saúde, tarefa primeira da qual não pode se furtar. ${ }^{32}$

Analisando o exposto, é possível observar que a intersetorialidade supõe uma troca de conhecimentos e saberes. Esse último compreende todos os saberes dos agentes envolvidos na saúde, sejam eles profissionais ou usuários do sistema, ou mesmo, os componentes de sua rede social. Cabe ressaltar que intersetorialidade não se refere a um conjunto de pessoas que estejam reunidas para resolver um problema, mas, sim, na composição da resolução de um problema por meio da coleta de informações dentre todos os atores reunidos.

Por outro lado, a transversalidade da saúde necessita da integração de vários pressupostos, dentre eles, o foco nas pessoas e no território, o envolvimento da população na identificação dos problemas, consequentemente, que as políticas devam estar voltadas para as necessidades daquela população. Nesse tipo de ação, pode o controle social, como já afirmado, selecionar fluxos comunicativos carregados com múltiplas informações (expectativas) relacionadas ao direito à saúde. Por meio dessa multiplicidade de informações, os sistemas parciais da sociedade terão melhores condições para realizar a melhor escolha e poder reduzir a complexidade sistêmica, muito embora deva-se levar em conta que "reduzir a complexidade é sempre, ao mesmo tempo, incrementá-la".33

${ }^{31}$ BRASIL. Ministério da Saúde. Secretaria de Atenção à Saúde. Política Nacional de Humanização da Atenção e Gestão
do SUS. Redes de produção de saúde. 1. ed. Brasília, DF: Ministério da Saúde, 2010. (Série B. Textos Básicos de
Saúde). $\quad$ Disponível em: $\quad$ http://www.redehumanizasus.net/sites/default/files/itens-do-acervo/files/
redes_de_producao_de_saude.pdf>. Acesso em: 21 jan. 2016 .
${ }^{32}$ BRASIL: Ministério da Saúde. Secretaria-Executiva Núcleo Técnico da Política Nacional de Humanização.
HumanizaSUS: humanização como eixo norteador das práticas de atençao e gestão em todas esferas do SUS. Brasília,
DF, 2004. p. 2. Disponível em: <http://www.ebah.com.br/content/ABAAAAlA8AH/humaniza-sus>. Acesso em: 21
jan. 2016. Revista de Direito Sanitário, São Paulo, v. 16, n. 1, p. 119, mar./jun. 2015. 
Nesse sentido, a atuação e efetivação da saúde pelos sistemas parciais envolvidos, como podemos observar, deve atuar com uma visão global, embora, ao mesmo tempo, deva respeitar as diferenças regionais, ou mesmo, locais. Por isso, esses sistemas parciais da sociedade não podem demarcar territórios limitados para a coleta de informações. Isso se demonstra evidente quando se percebe que não basta constitucionalizar o direito à saúde e dizer que ela é um "direito do cidadão e um dever do Estado, é preciso criar condições para que esse

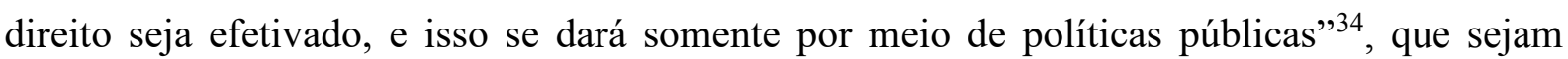
aplicadas de forma intersetorial e transversal.

A transversalidade, como citamos, é um fator que permeia a atuação do Sistema Parcial da Política no campo da Saúde Pública. No entanto, o que é uma atuação transversal desse Sistema Parcial da Sociedade? Embora não encontremos um conceito uníssono de transversalidade governamental, adotamos a definição que nos parece que melhor se aproxima da ideia que estamos empregando nesta tese.

Para Serra, ${ }^{35}$

La transversalidad es, al mismo tiempo, un concepto y un instrumento organizativo cuya función es aportar capacidad de actuación a las organizaciones en relación con algunos temas para los que la organización clásica resulta inadecuada. En este sentido, responde tanto a necessidade de diseno de lá organizacion como a necesidade de gestion.

Pela observação acima, é possível ressaltar a ideia que a transversalidade abrange a cooperação de diversos atores sociais, os quais procuram compreender a realidade de forma multidimensional. Nesse sentido, a ideia de transversalidade aproximar-se-ia muito de um mecanismo de gestão pública da saúde em que as adversidades não seriam enfrentadas apenas com as estruturas organizacionais tradicionais, ou seja, na forma da verticalidade e setorialidade. Cabe salientar que o autor não nega a existência das referidas ações verticais e setoriais, nem sugere que deixem de existir. Para ele, a ideia de transversalidade vai além dessa dualidade, tendo em vista a visão do todo (multidimensionalidade da sociedade). ${ }^{36}$

Dessa forma, observamos que a forma transversal com que deve ser tratado o tema da saúde, ou seja, permeando todas as áreas, todos os aspectos, hábitos e atitudes que estão

\footnotetext{
${ }^{34}$ VIAL, Sandra Regina Martini. Saúde e determinantes sociais: uma situação paradoxal. Comparazione e Diritto Civile, Salerno, v. 1, p. 16, 2010.

${ }^{35}$ SERRA, A. La gestión transversal: expectativas y resultados. In: CONGRESSO INTERNACIONAL DO CLAD SOBRE A REFORMA DO ESTADO E DA ADMINISTRAÇÃO PÚBLICA, 9., 2004, Madri. Anais eletrônicos... Madri, 2004. p. 3. Disponível em: <http://siare.clad.org/revistas/0049633.pdf>. Acesso em: 28 jan. 2016.

${ }^{36}$ SERRA, A. La gestión transversal: expectativas y resultados. In: CONGRESSO INTERNACIONAL DO CLAD SOBRE A REFORMA DO ESTADO E DA ADMINISTRAÇÃO PÚBLICA, 9., 2004, Madri. Anais eletrônicos... Madri, 2004. p. 3-16. Disponível em: <http://siare.clad.org/revistas/0049633.pdf>. Acesso em: 28 jan. 2016.
} 
presentes numa sociedade encontram infinitas possibilidades. Dentre tantas áreas que devem ser trabalhadas o tema da saúde de forma transversal uma é a educação. Em vista disso, “somente a participação de diferentes áreas, cada qual enfocando conhecimentos específicos à sua competência, pode garantir que alunos construam uma visão ampla do que é saúde". ${ }^{37}$

Essa forma transversal de abordar o tema da saúde corrobora demonstrando que a transversalidade auxilia os sistemas parciais envolvidos, uma vez que possibilita a inter-relação permanente com áreas afins à saúde que tem afinidade. Para exemplificar, cita-se a saúde sendo abordada de forma transversal pelo Sistema Parcial da Educação, quando se ensinam as questões que envolvem a orientação sexual e a saúde das pessoas envolvidas. A amplitude e complexidade que envolve o tema ganha evidência pela dificuldade vivenciada pelo Sistema Parcial da educação (escola), bem como pela sociedade que precisa ser orientada para esse tema.

Outro exemplo é encontrado no documento orientador da realização da $15^{\mathrm{a}}$ Conferência Nacional de Saúde que estabelece como eixo de transversalidade, para efetividade da saúde, a necessidade de continuar construindo um projeto de desenvolvimento que vise a assegurar: a soberania nacional; a democratização do sistema político; o emprego; o combate às desigualdades sociais; a continuidade das políticas sociais, investimento em saneamento e transporte público; a preservação do meio ambiente; o acesso aos serviços públicos de saúde, dentre outros. Essas são ações previstas para "superar o abismo entre o direito formal e o direito real". 38

A forma como os diferentes sistemas parciais da sociedade abordam o tema da saúde varia de acordo com a comunicação por eles selecionadas do ambiente e do processamento dessa comunicação que irá ocorrer no interior de cada Sistema Parcial. Isso se deve, em grande parte, por comunicações presentes no ambiente que são oriundas de outros sistemas parciais da sociedade. Nesse intuito, a abordagem do tema em disciplinas transversais visa a:

Favorecer o entendimento das diferentes maneiras como valores e práticas relativos à saúde em geral, ou especificamente, no âmbito da sexualidade humana, compõem e refletem-se nas vivências biológicas, afetivas e sociais. Na realidade, todos os blocos de conteúdo dos dois temas se permeiam e se entrelaçam, não sendo possível trabalhálos de forma desconectada. ${ }^{39}$

\footnotetext{
${ }^{37}$ BRASIL. Ministério da Educação. Parâmetros curriculares nacionais: saúde. Brasília, DF, 1998. p. 263. Disponível em: $<$ http:// portal.mec.gov.br/seb/arquivos/pdf/saude.pdf >. Acesso em: 28 jan. 2016. ${ }^{38}$ CONSELHO NACIONAL DE SAÚDE (CONAS). Documento orientador de apoio aos debates da $15^{\mathbf{a}}$ Conferência Nacional de Saúde. Brasília, 15 de maio de 2015. Disponível em: $<$ http://conselho. saude.gov.br/web_15cns/docs/05mai15_Documento_Orientador_15CNS.pdf $>$. Acesso em: 28 jan. 2016. ${ }^{39}$ BRASIL. Ministério da Educação. Parầmetros curriculares nacionais: saúde. Brasília, DF, 1998. p. 264. Disponível em: <http:// portal.mec.gov.br/seb/arquivos/pdf/saude.pdf >. Acesso em: 28 jan. 2016.
} 
Não só este, mas outros temas que envolvem transversalidade da saúde (ética, pluralidade cultural, consumo, trânsito, dentre outros) são trabalhados pelo Sistema Parcial da Educação. Prova desse raciocínio, verifica-se quando são abordados temas que envolvem a educação para o meio ambiente. Nesse sentido, o tema do direito à saúde e seus componentes essenciais para a produção de saúde são desenvolvidos juntamente com a noção de qualidade de vida. De fato, a forma transversal, como deve ser trabalhada pelo Sistema Parcial da Educação, irá demonstrar que os conhecimentos, valores e atitudes resultam em comportamentos concretos para o futuro, possibilitando assim trabalhar com o fator risco.

De maneira idêntica, a transversalidade do tema da saúde está prevista no Plano Nacional de Saúde (2012-2015). No referido plano, são estabelecidas duas diretrizes transversais. A primeira visa a desenvolver políticas públicas para a implementação de ações de saneamento básico e saúde ambiental, de forma sustentável, para a promoção da saúde e redução das desigualdades sociais. A segunda ação visa ao desenvolvimento de políticas públicas que possam contribuir para a erradicação extrema da pobreza no país. ${ }^{40}$

Analisando a primeira ação, verificamos que o Sistema Parcial da política desenvolve as políticas públicas da área rural de forma distinta da convencionalmente adotada nas áreas urbanas. Isso deve ocorrer tanto no dimensionamento tecnológico quanto na gestão da obra, ou dos recursos dispendidos com relação às diferentes realidades. De fato, as ações de governança em matéria de saúde devem ser empregadas com o desígnio de dar efetividade ao direito à saúde. Nesse caso, a repartição de competências entre estados, a transversalidade do direito à saúde, as tomadas de decisão de forma democrática e o cuidado com o desperdício, dentre outras, compõem referências importantes para a efetividade da saúde. ${ }^{41}$

A segunda diretriz é caracterizada pela transferência de renda e pelo acesso aos serviços públicos de saúde. Nesse sentido, podemos citar como efetivação do direito à saúde, a construção ou ampliação de Unidades Básicas de Saúde; ampliação de equipes de Saúde da Família; de Agentes Comunitários de Saúde; de Núcleos de Apoio à Saúde da família; Consultórios de Rua; Academias de Saúde, dentre outras. De fato, a execução das referidas ações deve ser articulada de forma intersetorial e transversal. Dessa forma, as comunicações selecionadas no ambiente, as quais são oriundas de diversos sistemas parciais, possibilitam que

\footnotetext{
${ }^{40}$ BRASIL. Ministério da Saúde. Secretaria-Executiva. Subsecretaria de Planejamento e Orçamento. Plano Nacional de Saúde-PNS: 2012-2015. Brasília, DF, 2011. p. 68. Disponível em: <http://conselho.saúde.gov.br/biblioteca/ Relatorios/plano_nacional_saúde_2012_2015.pdf>. Acesso em: 21 jan. 2016.

${ }^{41}$ OLIVEIRA, Gustavo Justino de. Efetivação do direito à saúde: ampliação do debate e renovação da agenda. Revista de Direito Sanitário, São Paulo, v. 1, n. 1, p. 82, mar./jun. 2015. p. 78-86,
} 
os sistemas parciais envolvidos melhor se adaptem às contingências e riscos a que estão expostos.

O referido plano continua referindo que as ações e esforços de vigilância sanitária devem ser:

\begin{abstract}
Concentrados na qualificação e expansão das ações de vigilância sanitária, a serem executadas de forma transversal e integrada à politica nacional de saúde, com o objetivo de prevenir e controlar os riscos oriundos da produção, comercialização e uso de bens e serviços mediante o monitoramento do risco sanitário, o controle sanitário, a regulamentação sanitária e a coordenação do sistema nacional de vigilância sanitária. $^{42}$
\end{abstract}

A transversalidade de atuação das ações que envolvem o tema da saúde deve ainda ser observada nas ações que visem ao controle sanitário de viajantes, meios de transporte, infraestrutura e prestação de serviços nas áreas portuárias, aeroportuárias, fronteiras e recintos alfandegários. Além disso, devem estar previstas ações transversais que visem à regulação de publicidade e propaganda dos compostos que fazem parte dos alimentos (sódio, açúcares e gorduras) e medicamentos. ${ }^{43}$

A complexidade que envolve o direito à saúde demonstra que a imbricação dos referidos temas em debate deve ser pensada em conjunto e de forma articulada, ou seja, de forma intersetorial e transversal. Devido à essa complexidade, que envolve o tema, torna os sistemas parciais da sociedade sensíveis a novas comunicações. Para tal, necessitam elaborar novas formas de abordagens, novas discussões que proporcionem novas comunicações compreensíveis para esses sistemas. Essas novas comunicações permitirão alimentar, ou mesmo, irritar esses sistemas, por consequência, será aumentado o nível de complexidade do próprio sistema. Dessa forma, ele terá melhores condições de selecionar uma das alternativas à disposição, o que diminui a própria complexidade desse sistema, como resultado, a complexidade do mundo ${ }^{44}$. Esse é o paradoxo, ou mesmo, o desafio a ser enfrentado pelos sistemas parciais da sociedade.

\footnotetext{
${ }^{42}$ BRASIL. Ministério da Saúde. Secretaria-Executiva. Subsecretaria de Planejamento e Orçamento. Plano Nacional de Saúde-PNS: 2012-2015. Brasília, DF, 2011. p. 80. Disponível em: <http://conselho.saúde.gov.br/biblioteca/ Relatorios/plano_nacional_saúde_2012_2015.pdf>. Acesso em: 28 jan. 2016.

${ }^{43}$ BRASIL. Ministério da Saúde. Secretaria-Executiva. Subsecretaria de Planejamento e Orçamento. Plano Nacional de Saúde-PNS: 2012-2015. Brasília, DF, 2011. p. 680. Disponível em: <http://conselho.saúde.gov.br/biblioteca/ Relatorios/plano_nacional_saúde_2012_2015.pdf>. Acesso em: 21 jan. 2016.

${ }^{44}$ REGO, Sergio, et al. Bioética e humanizaçãoo como temas transversais na formação médica. Revista Brasileira de Educação Médica, Rio de Janeiro, 32, n. 4, p. 482, 2008. Disponível em: <http://www.scielo.br/pdf/rbem/ v32n4/v32n4a11. pdf >. Acesso em: 28 jan. 2016.
} 
Nesse sentido, a transversalidade demonstra ser:

\begin{abstract}
Un instrumento de la alta dirección política de la corporación. Por esta razón, su liderazgo en el despliegue de elementos de transversalidad es decisivo, al igual que lo es el apoyo al trabajo de las unidades transversales, cuya actuación no cuenta con más respaldo que el de la legitimidad que se deriva de ese liderazgo global y su capacidad para aportar elementos de análisis, diseño y evaluación que mejoren la actuación del conjunto de la organización.
\end{abstract}

Com base nessa afirmação, passamos a compreender que a transversalidade é uma importante forma de organização e funcionamento do Sistema Parcial da Política. Cabe, no entanto, ressaltar que a estrutura operativa de forma vertical desse Sistema Parcial assegura a estabilidade do próprio sistema. Isso decorre, pois, uma visão transversal, possibilitando que o sistema possa ter uma visão horizontal, em dimensões de grande relevância social, com maior capacidade de perceber a realidade da sociedade que deve gestionar, com isso, melhorar a atuação conjuntural da própria organização do sistema.

Esforços governamentais para alimentar o sistema com informações (comunicações/irritações) auxiliam o sistema a fazer seleções. Exemplo dessa observação pode ser encontrado na Pesquisa Nacional de Saúde, realizada em 2013, apresentada no ano seguinte, em que foram apresentados dados dos suplementos-saúde que compõem um conjunto de informações sobre a população brasileira, de abrangência nacional, de grande relevância para o planejamento, formulação, monitoramento e avaliação das políticas de saúde. O referido estudo, além de coletar dados sobre a população da pesquisa, aspectos éticos, percepção de saúde, estilos de vida, existência de doenças crônicas, traz ainda informações sobre a utilização dos serviços de saúde, cobertura de planos de saúde privados e indicadores de saúde.

$\mathrm{O}$ acesso a esse universo de informações oriundas graças à intersetorialidade e à transversalidade permitirão que o Sistema Parcial da Política nutra-se delas a fim de subsidiar a formulação das novas políticas na esfera da saúde. É certo também que esse sistema deva desenvolver novos (velhos-novos ou novos-velhos) mecanismos de governança corporativa, ou mesmo, novas estratégias democráticas de ação, ou ainda, novas ferramentas capazes de produzir indicadores mensuráveis para monitoramento, controle e avaliação de suas políticas públicas em relação à efetividade do direito a ter direito à saúde.

Para Gallo ${ }^{45}$, a essencialidade da transversalidade e da intersetorialidade possibilita que o Sistema Parcial da Política permita a "participação social na gestão das políticas públicas,

\footnotetext{
${ }^{45}$ GALLO, Edmundo; SETTI, Andreia Faraoni Freitas. Território, intersetorialidade e escalas: requisitos para a efetivação dos objetivos de Desenvolvimento Sustentavel. Ciência Saúde Coletiva, Rio de Janeiro, v. 19, n. 11, p.
} 
particularmente da comunidade local". Isso demonstra ser possível a partir da análise situacional e estratégica, que se utilizará de informações diversas, uma vez que demonstram melhor as diversas interfaces de expectativas comunicacionais que permeiam o ambiente da sociedade.

Quanto mais precisas forem as informações selecionadas e enviadas para o interior desse sistema, maiores serão as condições (probabilidades) que ele terá para realizar a escolha mais apropriada a efetivar o direito à saúde. Com esse desígnio, a rede de filtros pode operar de forma isolada, ou mesmo, intersetorial.

Muitas vezes, as informações que poderiam auxiliar o Sistema Parcial da Política a tomar determinada decisão de forma acertada não são encontradas reunidas num determinado setor do ambiente da sociedade. Para tanto, faz-se necessário que o sistema (re)organize-se para filtrar e selecionar essas informações de forma transversal, ou seja, em diversos setores da sociedade. A referida (re)organização foi experimentada pela primeira vez durante o período de elaboração do Plano Plurianual (PPA, 2012-2015) do governo brasileiro. Esse procedimento, intersetorial foi novamente adotado no mês de julho do corrente ano durante a elaboração do PPA do quadriênio 2016-2019 (ESAF, 2016).

\section{Considerações Finais}

A complexidade do tema nos leva a conclusões não conclusivas, ou melhor dizendo, a ponderações. Temos consciência que o tema proposto e as hipóteses por nós levantadas são complexas. Compreendemos, da mesma forma, que existem infinitas perspectivas quanto às possíveis respostas, ou mesmo, com a demonstração de sua validade e confirmação. Muitas delas, outrossim, poderão ser adequadas e autênticas para tal finalidade, no entanto, a exceção deve ser feita àquela que pretende ser a única verdadeira.

Em decorrência disso, ao traçarmos, acima, o nosso objeto de pesquisa, lançamos e expomos o problema por nós levantado que indaga: a intersetorialidade e transversalidade das ações de saúde detém potencial seletivo e comunicativo de fluxos comunicacionais em saúde?

A operação comunicativa desempenhada por essa ação pode cooperar para que os sistema parciais da sociedade sejam irritados com informações que lhe permitam ter maiores

43847, nov. 2014. Disponível em: <http://www.scielo.br/pdf/csc/v19n11/1413-8123-csc-19-11-4383.pdf>. Acesso em: 28 jan. 2016. 
probabilidades de fazer a escolha mais apropriada (decisão), a fim de garantir e efetivar o direito fundamental à saúde no Brasil?

Ora, acreditamos que as hipóteses levantadas sejam pertinentes e comprováveis. Isso pois, é por intermédio do potencial comunicativo que residem às probabilidades de avanços ou retrocessos no âmbito social. Por conseguinte, quando as comunicações não sucedem, temos como implicação o abandono dos sistemas parciais da sociedade, que, em última análise, representam uma acepção de estagnação social. Contudo, um outro ponto de vista pode demonstrar que é quando acontecem comunicações sociais que afloram as possibilidades de crescimento e desenvolvimento social.

Dito de outra forma, o desenvolvimento social na sociedade sobrevém quando as comunicações são desenvolvidas de forma constante pelos sistemas parciais da sociedade. Por decorrência disso, ou melhor dizendo, em paralelo ao crescimento das comunicações sucede o aumento da complexidade interna de cada um desses sistemas. De forma paradoxal ao aumento da complexidade sistêmica, ocorre internamente a redução dessa mesma complexidade (via uma operação denominada seleção), por conseguinte, igualmente ocorre a redução da complexidade do ambiente que cerca aquele Sistema Parcial da Sociedade.

Quanto mais precisas forem as informações selecionadas e enviadas para o interior desse sistema, maiores serão as condições (probabilidades) que ele terá para realizar a escolha mais apropriada a efetivar o direito à saúde. Com esse desígnio, a intersetorialidade e a transversalidade operam na catalisação e potencialização de informações que estão presentes no ambiente do sistema.

A essencialidade da transversalidade e da intersetorialidade possibilita que o Sistema Parcial da Política possa utilizar-se da participação social na gestão das políticas públicas, particularmente da comunidade local. Isso demonstra ser possível a partir da análise situacional e estratégica, que se utilizará de informações diversas, uma vez que demonstram melhor as diversas interfaces de expectativas comunicacionais que permeiam o ambiente da sociedade.

Observamos ainda que o elevado nível de complexidade do tema obrigou os Sistemas Parciais da sociedade a se (re)organizarem de forma constante para que conseguissem contemplar efetivamente as expectativas em matéria do direito à saúde.

Nesse sentido, a transversalidade e a intersetorialidade de ações voltadas às Políticas Públicas de Saúde demonstram potencial para alcançar o êxito pretendido. Por fim, a descentralização operacional e a autonomia dos gestores permitiram que essas ações (Políticas Públicas de Saúde) fossem postas em prática, observando-se a realidade local dos indivíduos que posteriormente seriam beneficiados com as ações de saúde. 
Possibilitando, por assim dizer, melhor efetividade da saúde como um direito fundamental de todo e qualquer cidadão.

\section{Referências bibliográficas}

AZEVEDO, Elaine de. PELICIONI, Maria Cecilia Focesi. WESTPHAL, Marcia Faria. Práticas intersetoriais nas políticas. Physis Revista de Saúde Coletiva, Rio de Janeiro, v. 22, n. 4, p. 1335, 2012.

BRASIL. Ministério da Saúde. Portaria n. 2.446 de 11 de novembro de 2014. Redifine a Política Nacional de Promoção da Saúde (PNPS). Disponível em:

<http://bvsms.saúde.gov.br/bvs/saúdelegis/gm/2014/prt2446_11_11_2014.html>.

BRASIL. Conselho Nacional de Secretários de Saúde. As conferências nacionais de saúde: evolução e perspectivas. Brasília, DF: CONASS, 2009.

BRASIL. Ministério da Saúde. Secretaria-Executiva. Subsecretaria de Planejamento e Orçamento. Plano Nacional de Saúde-PNS: 2012-2015. Brasília, DF, 2011. Disponível em: $<$ http://conselho.saúde.gov.br/biblioteca/Relatorios/plano_nacional_saúde_2012_2015.pdf>.

BRASIL. Conselho Nacional de Secretários de Saúde. As conferências nacionais de saúde: Evolução e perspectivas. Brasília, DF: CONASS, 2009.

BRASIL. Ministério do Planejamento Desenvolvimento e Gestão. O que é o PPA? Brasília, DF, 22 maio 2015. Disponível em: <http://www.planejamento.gov.br/servicos/faq/ planejamento-governamental/planoplurianual-ppa/o-que-eacute-o-ppa $>$.

BRASIL. Ministério da Educação. Parâmetros curriculares nacionais: saúde. Brasília, DF, 1998. p. 264. Disponível em: <http:// portal.mec.gov.br/seb/arquivos/pdf/saude.pdf >.

BRASIL: Ministério da Saúde. Secretaria-Executiva Núcleo Técnico da Política Nacional de Humanização. HumanizaSUS: humanização como eixo norteador das práticas de atençao e gestão em todas esferas do SUS. Brasília, DF, 2004. p. 2. 
Disponível em: <http://www.ebah.com.br/content/ABAAAAlA8AH/humaniza-sus>.

BRASIL. Ministério da Saúde. Secretaria de Atenção à Saúde. Política Nacional de Humanização da Atenção e Gestão do SUS. Redes de produção de saúde. 1. ed. Brasília, DF: Ministério da Saúde, 2010. (Série B. Textos Básicos de Saúde). Disponível em: $<$ http://www.redehumanizasus.net/sites/default/files/itens-do acervo/files/redes_de_producao_de_saude.pdf $>$.

CONFERÊNCIA NACIONAL DE SAÚDE, 12., 2003, Brasília, DF. Relatório final. Brasília, DF: Ministério da Saúde, 2004. p. 44. Disponível em: <http://conselho. saúde.gov.br/biblioteca/Relatorios/relatorio_12.pdf>.

CONSELHO NACIONAL DE SAÚDE (CONAS). Documento orientador de apoio aos debates da 15 ${ }^{\text {a }}$ Conferência Nacional de Saúde. Brasília, 15 de maio de 2015. Disponível em: <http://conselho.saude.gov.br/web_15cns/docs/05mai15_Documento_Orientador - 15CNS.pdf $>$.

CORREIA, Maria Valéria Costa. Que controle social? Os conselhos de saúde como instrumento. Rio de Janeiro: Fiocruz, 2000.

DALLARI, Sueli Gandolfi; NUNES JUNIOR, Vidal Serrano. Direito sanitário. São Paulo: Verbatim, 2010.

DSSBR - DETERMINANTES SOCIAIS EM SAÚDE NO BRASIL. Determinantes Sociais em Saúde. Disponível em http://dssbr.org/site/sobre/

FEUERWERKER, L. M.; COSTA, H. Intersetorialidade na rede unida. Saúde em Debate, Rio de Janeiro, v. 22, p. 13, 2000.

GALLO, Edmundo; SETTI, Andreia Faraoni Freitas. Território, intersetorialidade e escalas: requisitos para a efetivação dos objetivos de Desenvolvimento Sustentavel. Ciência Saúde Coletiva, Rio de Janeiro, v. 19, n. 11, p. 4383, nov. 2014. Disponível em: <http://www. scielo.br/pdf/csc/v19n11/1413-8123-csc-19-11-4383.pdf>. 
JUNKEIRA, Luciano A. Prates. Descentralização e intersetorialidade. Revista Saúde e Sociedade, Sao Paulo, v. 6, n. 2, p. 32, 1997.

MARQUES, Silvia Badim. Direito à saúde: complexidade e enfrentamentos extrajudiciais. Brasília, DF: CONASS. 2015.

OLIVEIRA, Gustavo Justino de. Efetivação do direito à saúde: ampliação do debate e renovação da agenda. Revista de Direito Sanitário, São Paulo, v. 1, n. 1, p. 82, mar./jun. 2015.

PAIM, Jairnilson Silva. O que é SUS. Rio de Janeiro: Fiocruz, 2009.

REGO, Sergio, et al. Bioética e humanizaçãoo como temas transversais na formação médica. Revista Brasileira de Educação Médica, Rio de Janeiro, 32, n. 4, p. 482, 2008. Disponível em: <http://www.scielo.br/pdf/rbem/v32n4/v32n4a11. pdf $>$.

SERRA, A. La gestión transversal: expectativas y resultados. In: Congresso Internacional do Clad Sobre a Reforma do Estado e da Administração Pública, 9., 2004, Madri. Anais eletrônicos... Madri, 2004. p. 3-16. Disponível em: <http://siare.clad.org/revistas/0049633. pdf $>$.

VIAL, Sandra Regina Martini. Construção do sistema social da saúde a partir da teoria sistêmica de Niklas Luhmann. Revista de Direito Sanitário, São Paulo, v. 16, n. 1, p. 119, mar./jun. 2015.

VIAL, Sandra Regina Martini. Saúde e determinantes sociais: uma situação paradoxal. Comparazione e Diritto Civile, Salerno, v. 1, p. 16, 2010.

VIAL, Sandra Regina Martini. Direito fraterno na sociedade cosmopolita. Contribuciones desde Coatepec, Toluca, n. 12, p. 123-138, enero/jun. 2007. Disponível em: $<$ http://www.redalyc.org/pdf/281/ 28101207.pdf $>$. 


\title{
ANÁLISE DA RESPONSABILIDADE CIVIL DO ESTADO POR OMISSÃO: ESTUDO DE CASO SOBRE A ACIDENTALIDADE PROVOCADA PELO ROMPIMENTO DA BARRAGEM EM MARIANA/MG
}

\author{
Renata Martins de Souza \\ Rede Doctum e Defensoria Pública do Estado de Minas Gerais
}

Edimur Ferreira de Faria

PUC Minas

\begin{abstract}
Resumo
O presente artigo tem por objetivo analisar as implicações decorrentes do rompimento da barragem de Fundão em 2015, localizada no Município de Mariana/MG. Após identificadas as causas e consequências de tal tragédia, bem como apontadas as medidas até então adotadas com a finalidade de reparação dos danos, será feita análise sobre a teoria da responsabilidade civil e ambiental do Estado, visando demonstrar que assim como as empresas diretamente responsáveis pelo desastre ambiental de Mariana, os entes públicos também devem ser responsabilizados, vez que foram negligentes quando da emissão da licença ambiental e da fiscalização da operação da barragem.
\end{abstract}

Palavras-chave: desastre ambiental, reparação dos danos, Responsabilidade do Estado por omissão.

\section{Abstract/Resumen/Résumé}

The objective of this article is to analyze the implications of the disruption of the Fundão dam in 2015, located in the Municipality of Mariana/MG. After identifying the causes and consequences of the tragedy, as well as the measures repairing the damage, will be made analysis on the theory of civil and environmental responsibility of the State, aiming to demonstrate that as well as the companies directly responsible for the environmental disaster of Mariana, public entities should also be held responsible, since they were negligent when issuing the environmental license and monitoring the operation of the dam. 
Keywords/Palabras-claves/Mots-clés: environmental disaster; repairing the damage; Liability of the State for omission.

\section{Introdução}

O objeto do presente artigo consiste na análise da responsabilidade civil do Estado e sua aplicabilidade no caso do rompimento da barragem do Fundão, ocorrido em novembro de 2015, no Município de Mariana/MG, Região Central do Estado de Minas Gerais, considerado por alguns (dentre eles, a ministra do Meio Ambiente á época, Izabella Teixeira ${ }^{1}$ ) o maior desastre ambiental da história brasileira, tendo causado mortes, desalojamentos, além de diversos impactos socioambientais e socioeconômicos às regiões ao longo do Rio Doce.

A barragem do Fundão era um dos locais de armazenamento dos rejeitos produzidos pela exploração da Mina de Germano, localizada no Distrito de Santa Rita Durão, em Mariana/MG, e realizada pela mineradora SAMARCO MINERAÇÃO S.A.

O presente artigo emprega o método de pesquisa essencialmente bibliográfico, descritivo e exploratório, baseada na análise da doutrina administrativa, artigos publicados em jornais e revistas especializadas e jurisprudências que versam o tema ora proposto, e tem como referencial teórico autores como Celso Antônio Bandeira de Mello (2014), Edimur Ferreira de Faria (2015), José dos Santos Carvalho Filho (2014), entre outros.

O problema proposto consiste na seguinte indagação: a despeito da responsabilidade das empresas envolvidas direta e indiretamente pela atividade mineraria, que deram causa ao acidente, a União e o Estado de Minas Gerais também são civilmente responsáveis por conduta omissiva por ocasião do licenciamento de operação e na fiscalização da atividade da mineradora, principalmente no que tange à barragem?

\section{Os danos causados pelo desastre ambiental e as medidas destinadas à reparação dos mesmos}

A barragem de Fundão, de propriedade da Sociedade Anônima Samarco Mineração S.A., foi alvo de rompimento, que acarretou a erosão da barragem de Santarém e resultou no derramamento de cerca de 50 milhões de metros cúbicos de rejeitos de mineração no vale do

\footnotetext{
${ }^{1}$ AGÊNCIA BRASIL. Rompimento da barragem é a maior catástrofe ambiental do Brasil, diz ministra. Disponível em<http://agenciabrasil.ebc.com.br/geral/noticia/2015-11/rompimento-da-barragem-e-maior-catastrofeambiental-do-brasil-diz-ministra/>. Acesso em: 05 jan. 2018.
} 
Rio Doce. Em virtude disso, foram imediatamente expelidos aproximadamente 34 milhões de metros cúbicos de lama e dejetos provenientes da exploração, os quais atingiram o Rio Doce e seguiram até o mar no Estado do Espírito Santo.

Segundo dados coletados até 08 de janeiro de 2018, passados dois anos do maior desastre ambiental do Brasil, a quantificação de danos aos moradores afetados e à natureza ainda não foi concluído (Exame, 2017²).

\subsection{Das causas e consequências (danos) do rompimento da barragem}

Desde o acidente, busca-se averiguar as causas, as circunstâncias e as consequências da tragédia.

A perda de estabilidade na fundação de rejeitos da barragem de Fundão, da Samarco, em um processo conhecido como liquefação, foi a causa do rompimento da estrutura, concluiu uma investigação independente contratada pelas mineradoras Samarco e suas controladoras, as empresas brasileira VALE S.A. e a australiana BHP BILLINTON BRASIL LTDA., divulgada em agosto de 2016. (Exame, 2016 ${ }^{3}$ ).

Além disso, um estudo realizado pelo Tribunal de Contas da União (TCU) ${ }^{4}$, apontou que o Departamento Nacional de Produção Mineral (DNPM) foi "falho e omisso" ao fiscalizar a segurança das barragens brasileiras, contribuindo para a tragédia de Mariana (MG). A conclusão consta de relatório sigiloso da área técnica do TCU. O documento aponta que a autarquia federal não foi capaz de garantir a implementação, pela mineradora Samarco, dos padrões exigidos pela Política Nacional de Segurança de Barragens, em vigor desde 2010.

Cabe, ainda, acrescentar que na ação civil pública movida pelo Ministério Público Federal (Ação n. 0069758-61.2015.4.01.3400), objetivando a reparação dos danos, consta que documentos referentes ao processo de revalidação de uma das licenças ambientais da barragem de Fundão, indicavam que o Ministério Público do Estado de Minas Gerais (MPMG) havia solicitado, em 2013, como condicionantes para emissão da nova licença de operação (LO), a

\footnotetext{
2 REVISTA EXAME Mariana: o arrastado processo de indenização das famílias. Disponível em $<\mathrm{https}$ ://exame.abril.com.br/brasil/mariana-o-arrastado-processo-de-indenizacao-das-familias/>. Acesso em: 08 jan. 2018.

3 REVISTA EXAME. Liquefação causou rompimento de barragem da Samarco. Disponível em $<\mathrm{https}$ ://exame.abril.com.br/brasil/liquefacao-causou-rompimento-de-barragem-da-samarco/>. Acesso em: 08 jan. 2018.

${ }^{4}$ TRIBUNAL DE CONTAS DA UNIÃO. TCU aponta risco de novos acidentes envolvendo barragens no País. Disponível em <http://portal.tcu.gov.br/imprensa/noticias/tcu-aponta-risco-de-novos-acidentes-envolvendobarragens-no-pais.htm>. Acesso em: 08 jan. 2018.
} 
inclusão da análise de ruptura da barragem e a elaboração de plano de contingência em caso de riscos ou acidentes, especialmente em relação à comunidade de Bento Rodrigues, distrito do Município de Mariana-MG. De fato, o Ministério Público estadual chegou a apontar falhas no licenciamento da barragem do Fundão, destacando que a autorização foi concedida sem projeto executivo e estudo sobre drenagem. O órgão considera que apenas dados básicos relativos ao empreendimento foram apresentados à época do licenciamento e apura por que, mesmo assim, a autorização foi concedida pela Fundação Estadual do Meio Ambiente (FEAM), vinculada ao Estado de Minas Gerais. ${ }^{5}$ Diante desse quadro, sustenta-se que medidas mais rigorosas deveriam ter sido adotadas para evitar o rompimento da barragem.

No que se refere às consequências do desastre, cumpre registrar que muitos dos danos sequer puderam ser até então apurados. Mas o fato é que ante o montante exorbitante do material despejado, houve desastrosa série de danos, que compreende: a morte de 19 pessoas, dentre trabalhadores da Samarco e moradores das comunidades afetadas; no desalojamento de populações, bem como em evidente destruição/poluição do Rio Doce e seus afluentes; a morte de várias espécies da fauna e flora local; a danificação do patrimônio histórico-cultural, paisagístico e arqueológico; além dos danos socioeconômicos e morais à toda região do impacto, inclusive, aos diversos povos indígenas e comunidades tradicionais da área atingida.

Estima-se que em decorrência do rompimento da barragem cerca de 450.000 pessoas tenham sido afetadas pelo rompimento da barragem em foco, seja por terem perdido suas casas e meios de subsistência ou por terem tido seu consumo de água potável interrompido.

Danos socioambientais e econômicos foram provocados pelo rompimento da barragem. Além de atingir o meio ambiente (em seu aspecto natural e cultural), o desastre também afetou a vida dos indivíduos e suas comunidades, em seus aspectos estruturais e econômicos. Comunidades indígenas e tradicionais, moradores do distrito de Bento Rodrigues e toda a economia regional restaram prejudicados pelo evento.

Com o rompimento da barragem do Fundão, o Instituto Brasileiro de Meio Ambiente e Recursos Renováveis - Ibama - órgão responsável pelo monitoramento e controle ambiental no plano federal, iniciou o acompanhamento in loco da evolução do desastre. O resultado desse trabalho culminou na elaboração de um documento científico intitulado "Laudo Técnico Preliminar: Impactos ambientais decorrentes do desastre envolvendo o rompimento da

\footnotetext{
${ }^{5} \mathrm{O}$ GLOBO. MP de Minas vê falhas em licenciamento da barragem do Fundão. Disponível em $<$ https://oglobo.globo.com/brasil/mp-de-minas-gerais-ve-falhas-em-licenciamento-da-barragem-de-fundao18494612 >. Acesso em: 08 jan. 2018.
} 
barragem de Fundão, em Mariana, Minas Gerais",6 o qual fora concebido para subsidiar a propositura de Ação Civil Pública por danos causados ao meio ambiente pela mineradora Samarco. Nele, o órgão ambiental evidenciou e relatou "impactos agudos de contexto regional, entendidos como a destruição direta de ecossistemas, prejuízos à fauna, flora e socioeconômicos, que afetaram o equilíbrio da Bacia Hidrográfica do rio Doce, com desestruturação da resiliência do sistema".

Dentre tantos outros danos, reportagem do Jornal Estado de Minas ${ }^{7}$, realizada 02 anos após o desastre, destaca a irreparável consequência desse rompimento, que engoliu a história de Bento Rodrigues e dos indígenas da tribo do povo Krenak, que viviam às margens do Rio Doce. A tragédia, ressalta a matéria, implicou drástica mudança nos hábitos dos indígenas, bem como sufocou antigos costumes, que incluíam a pesca e os rituais na beira do rio, cuja água ainda está imprópria para consumo.

Diante do exposto acima, verifica-se a enorme gama de danos ocasionados pelo rompimento da barragem do Fundão.

\subsection{As medidas de reparação dos danos decorrentes do rompimento da barragem do Fundão}

Desde o rompimento da barragem diversas medidas extrajudiciais e judiciais são adotadas por autoridades federais e estaduais, visando a reparação dos prejuízos, a exemplo da assinatura de Termo de Compromisso Preliminar entre a Companhia, o Ministério Público de Minas Gerais e o Ministério Público Federal, com a prestação de caução para tutela ambiental emergencial; da instauração de inquéritos civis e criminais e do ajuizamento de ações civis públicas.

Nesse sentido, destaca-se a Ação Civil Pública proposta pelo Ministério Público Federal na $12^{\mathrm{a}}$ Vara Federal da Seção Judiciária de Minas Gerais, que pretende, também, a responsabilização dos Entes públicos fiscalizadores, quais sejam, a União, o Estado de Minas Gerais, o Estado do Espírito Santo e seus órgãos ambientais ${ }^{8}$. Por intermédio da referida ação,

\footnotetext{
${ }^{6}$ IBAMA. Disponível em

<http://www.ibama.gov.br/phocadownload/barragemdefundao/laudos/laudo_tecnico_preliminar_Ibama.pdf >. Acesso em: 08 jan. 2018.

7 JORNAL ESTADO DE MINAS. Agora o rio corre calado. Como o rompimento da barragem da Samarco matou a fé do povo indígena Krenak no sagrado Rio Doce. Disponível em < https://www.em.com.br/app/noticia/gerais/2017/11/05/interna_gerais,914115/agora-o-rio-corre-caladobarragem-de-mariana-destruiu-a-fe-do-povo.shtml>. Acesso em: 08 jan. 2018.

${ }^{8}$ MINISTÉRIO PÚBLICO FEDERAL. Disponível em < http://www.mpf.mp.br/mg/sala-de-imprensa/docs/acpsamarco/view>. Acesso em: 10 nov 2017.
} 
pugnou o Ministério Público Federal pela condenação dos réus à: a) Reparação integral do dano socioambiental; b) Adoção de medidas de compensação em relação aos danos não reparados; c) Indenização da coletividade pelo tempo que ficou inviabilizada de desfrutar do meio ambiente equilibrado; d) Indenização da coletividade pelo dano moral coletivo; e) Reparação integral de todos os danos socioeconômicos e humanos, materiais e imateriais; f) Realização de consulta com os povos indígenas e comunidades tradicionais afetadas para a recuperação ambiental de suas terras e indenização pelos danos socioeconômicos, socioculturais e humanos sofridos; g) Ressarcimento dos gastos públicos; h) Apoio ao fortalecimento das unidades de conservação existentes na Bacia Hidrográfica do Rio Doce, entre outras medidas que objetivam a criação e fortalecimento de outras unidades de conservação; i) Conclusão da Reserva de Desenvolvimento Sustentável da Foz do Rio Doce; j) Adoção de estratégias para o desenvolvimento de outras atividades econômicas na região, diminuindo a dependência com relação à indústria mineraria; k) Recuperação de demais áreas de preservação permanente e nascentes que não estejam abrangidas nas medidas de reparação ou compensação; e l) Criação e manutenção de um fundo privado destinado ao custeio da elaboração e execução dos planos e medidas socioeconômicos e socioambientais, ressalvada as respectivas responsabilidades de cada réu, dando, por fim, à causa o valor de $\mathrm{R} \$ 155.052 .0000 .000,00$ (cento e cinquenta e cinco bilhões e cinquenta e dois milhões de reais).

Apesar disso, segundo dados colhidos em novembro de 2017, pelo Jornal Estado de Minas $^{9}$, os atingidos pelo desastre ainda sofrem com a demora das indenizações. Parecer da Organização das Nações Unidas (ONU) formulado em 2016 chegou a apontar que as medidas que foram tomadas após a tragédia foram "insuficientes", tendo o órgão feito apelo para que as autoridades do País determinem ações que possam solucionar os efeitos da tragédia. (Exame, $\left.2016^{10}\right)$.

Importante registrar que visando a mitigação e a reparação, inclusive indenização, pelos impactos socioambientais e socioeconômicos causados, bem como a prestação de assistência social aos impactados, dentre outros, em março de 2016, a SAMARCO firmou o

\footnotetext{
${ }^{9}$ JORNAL ESTADO DE MINAS. Agora o rio corre calado. Como o rompimento da barragem da Samarco matou a fé do povo indígena Krenak no sagrado Rio Doce. Disponível em < https://www.em.com.br/app/noticia/gerais/2017/11/05/interna_gerais,914115/agora-o-rio-corre-caladobarragem-de-mariana-destruiu-a-fe-do-povo.shtml>. Acesso em: 08 jan. 2018.

${ }^{10}$ REVISTA EXAME. Mariana: O que a Samarco fez e deixou de fazer após 1 ano?. Disponível em $<$ https:/exame.abril.com.br/brasil/mariana-o-que-a-samarco-fez-e-deixou-de-fazer-apos-1-ano/>. Acesso em: 08 jan. 2018.
} 
Termo de Transação e Ajustamento de Conduta ${ }^{11}$, assinado entre a empresa, suas acionistas e os governos Federal e dos Estados de Minas e do Espírito Santo, no qual se comprometeu a conduzir 41 programas de recuperação ambiental e reparação socioeconômica. Assim, como resultado desse acordo preliminar, em agosto de 2016, foi criada a Fundação Renova ${ }^{12}$, com o objetivo de gerenciar a reparação dos danos resultantes do desastre; tratando-se de instituição autônoma, independente e sem fins lucrativos, que aplica um programa de indenização específico, que faz uso da mediação (método consensual de resolução de conflitos) para possibilitar reparação mais célere aos impactados.

Segundo salienta o mediador e especialista em sistemas de resolução de disputas, Diego Faleck (2017, p. 14) o processo de diálogo conta com a presença das seguintes partes: Fundação Renova; representantes de impactados; profissionais técnicos e instituições de referência; agentes públicos, como membros do Ministério Público, secretarias municipais e estaduais, Defensoria Pública; e equipe de mediadores neutros.

Atualmente, contando com mais de uma dezena de escritórios instalados nas regiões impactadas e um orçamento previsto de cerca de 20 bilhões de reais a ser custeado pela SAMARCO e suas controladoras até 2030, a Fundação tem 42 programas para executar nesse período - desde a indenização das populações afetadas até o reflorestamento das margens dos rios e dos córregos que cortam a região.

Desde 2015, cerca de 2,3 bilhões de reais foram desembolsados, a maior parte diretamente pela Samarco, em ações emergenciais. 4,4 bilhões, aproximadamente, deverão ser investidos pela Renova em seus três primeiros anos de atuação, até 2019. (Exame, 2017 ${ }^{13}$ ).

Segundo dados coletados, Novo Bento Rodrigues está prometida para ser erguido a aproximadamente dez quilômetros do antigo. A maioria dos moradores atingidos, hoje vive na cidade de Mariana, em imóveis alugados pela Samarco e recebe ajuda financeira da Fundação: são 8.274 cartões de 01 salário mínimo $+20 \%$ por dependente + valor de uma cesta básica por mês. Os reassentamentos prometidos ainda não foram finalizados, e algumas famílias moram em casas alugadas, sem previsão de mudança. (Exame, 2017 ${ }^{14}$ ).

\footnotetext{
${ }^{11}$ TERMO DE TRANSAÇÃO E DE AJUSTAMENTO DE CONDUTA. Disponível em $<$ http://www.meioambiente.mg.gov.br/images/stories/2016/DESASTRE_MARIANA/CIF/ACORDO_FINAL_-_ASSINADO.PDF>. Acesso em: 08 jan. 2018.

$\overline{12}$ FUNDAÇÃO RENOVA. Disponível em < $<$ http://www.fundacaorenova.org/>. Acesso em: 08 jan. 2018.

${ }^{13}$ REVISTA EXAME. O que a Samarco fez e deixou de fazer após 1 ano? Disponível em $<$ https://exame.abril.com.br/brasil/mariana-o-que-a-samarco-fez-e-deixou-de-fazer-apos-1-ano/>. Acesso em: 08 jan. 2018.

${ }^{14}$ REVISTA EXAME. Fundação Renova corre para reparar tragédia do Rio Doce. Disponível em $<$ https://exame.abril.com.br/revista-exame/em-compasso-de-espera-2/>. Acesso em: 08 jan. 2018.
} 
A Fundação ainda paga 09 salários mínimos mensais por família do povo indígena Krenak, fornece 3 mil litros de água mineral diariamente à tal comunidade, além de se comprometer a reparar as estradas da reserva.

Apesar disso, quase nenhuma das pessoas atingidas, salvo os parentes de vítimas fatais, foi indenizada até agora. A verba que deveria ser destinada à recuperação ambiental também não foi liberada. Até setembro de 2017, haviam sido desembolsados 500 milhões de reais em indenizações. A expectativa da Renova é de que até meados de 2018 todas as indenizações estejam concluídas. (Exame, 2017 ${ }^{15}$ ).

Sobre a possível retomada das operações da Samarco, a Secretaria de Meio Ambiente e Desenvolvimento Sustentável de Minas Gerais informou que as atividades permanecerão suspensas até que os danos tenham sido reparados.

\section{Responsabilidade civil do Estado}

O rompimento da barragem de Fundão é por muitos considerado um desastre ambiental sem precedentes no Brasil, que teve como responsável indireto o Poder Público, o qual teria concedido licença ambiental irregular à Samarco; decorrendo daí a necessidade de reflexão sobre a responsabilidade civil estatal.

Com efeito, o Ministério Público Federal ${ }^{16}$, considerou ser "patente a omissão da União e do Estado de Minas Gerais, por meio de seus órgãos e entidades ambientais e minerário, em fiscalizar a segurança da barragem de rejeitos de Fundão. Há responsabilidades primárias, decorrentes dessa omissão, e responsabilidades subsidiárias, incidentes no caso de descumprimento das obrigações por parte das empresas". Em virtude disso, o órgão ministerial pugnou também pela condenação da União e dos Estados de Minas Gerais e do Espírito Santo, sustentando que esses devem "responder pela omissão, com atuações que a supram plenamente", e, sobretudo, "devem controlar efetivamente as ações de planejamento e da execução das medidas de reparação integral do meio ambiente, não podendo terceirizar essa responsabilidade, tipicamente de Estado, para as empresas poluidoras".

\footnotetext{
${ }^{15}$ REVISTA EXAME. Mariana: o arrastado processo de indenização das famílias. Disponível em $<$ https://exame.abril.com.br/brasil/mariana-o-arrastado-processo-de-indenizacao-das-familias/>. Acesso em: 08 jan. 2018.

${ }^{16}$ MINISTÉRIO PÚBLICO FEDERAL. Disponível em < http://www.mpf.mp.br/mg/sala-de-imprensa/docs/acpsamarco/view>. Acesso em: 10 nov 2017.
} 
A responsabilidade civil do Estado consiste no dever de ressarcir os danos que causa a terceiros em razão da atividade que realiza. Apesar da ampla aceitação da responsabilidade estatal na atualidade, em virtude das condutas positivas dos agentes públicos, dúvidas e debates ainda persistem em relação às hipóteses de omissão do Estado, conforme será visto adiante.

\subsection{Evolução da responsabilidade civil do Estado}

Para MELLO (2014, p. 937) a responsabilidade patrimonial extracontratual do Estado consiste na obrigação que lhe incumbe de reparar economicamente os danos lesivos à esfera juridicamente garantida de outrem e que lhe sejam imputáveis em virtude de comportamentos unilaterais, lícitos ou ilícitos, comissivos ou omissivos, materiais ou jurídicos.

O reconhecimento do dever de indenizar por parte do Estado é fruto de processo evolutivo. Com efeito, ressalta FARIA (2015, p. 569) que "a reponsabilidade civil do estado passou por processo mutativo na medida da evolução da sociedade e do Estado". Assim, ao longo da história, é possível verificar o desenvolvimento que se constrói a partir da ideia de irresponsabilidade do Estado (modelo adotado pelas primeiras Constituições brasileiras), passando pelo acolhimento, por empréstimo, de teorias privatistas (baseadas no Código Civil e tendo a culpa do agente público como fundamento), até chegar ao modelo atual, momento em que se reconhece que o dever do Estado de indenizar deixou de se basear em atuação culposa do agente público para se embasar na ideia de risco administrativo assumido pelo Estado ao exercer suas diversas atividades administrativas.

Segundo CARVALHO FILHO (2014, p. 554), "na metade do século XIX, a ideia que prevaleceu no mundo ocidental era de que o Estado não tinha qualquer responsabilidade pelos atos praticados por seus agentes". Tal teoria, denominada irresponsabilidade, tinha como fundamento a soberania estatal e a infalibilidade do soberano. À época, sustentado na teoria divina dos reis, não se admitia responsabilização do Estado pelo fato de o rei não errar, por ser representante de Deus. Mesmo depois do paradigma do Estado Absolutista e início do Estado de Direito permaneceu o entendimento de que ao Estado não se atribuía qualquer parcela de responsabilidade em virtude de atos de seus agentes.

Essa situação foi superada, segundo FARIA (2015, p. 57) no século XIX, quando a irresponsabilidade estatal fora substituída pela responsabilização em situações específicas, ou seja, no caso de atuação culposa do agente. A teoria Civilista da Culpa equiparava, assim, o Estado ao particular, obrigando-o a indenizar somente pelos danos causados aos particulares nas mesmas hipóteses em que a obrigação existe para os indivíduos. Esclarece, assim, 
CARVALHO FILHO (2014, p. 555) que o Estado não poderia ser responsabilizado pelos atos de império (os que decorriam do poder soberano do Estado e eram regidos pelas normas de Direito Público). Com efeito, por essa teoria ficou estabelecido que o Estado responderia apenas pelos atos que decorressem do exercício de atos de gestão.

Além disso, o lesado não precisava identificar o agente estatal causador do dano. Era necessário, somente, comprovar o mau funcionamento do serviço público. Com isso, a doutrina passou a chamar essa situação como culpa anônima ou falta do serviço. A ausência do serviço implicaria reconhecimento da existência de culpa, assim, imperativa se fazia a comprovação que o fato danoso se originava do mau funcionamento do serviço.

Posteriormente, se evolui para a adoção da Teoria Objetiva, a qual, segundo CARVALHO FILHO (2014, p. 556) “dispensa a verificação do fator culpa em relação ao fato danoso". No Estado moderno, como decorrência do reconhecimento do poder dos Estados, os quais teriam de arcar com o risco natural decorrentes de suas numerosas atividades, surge a Teoria do Risco Administrativo, ainda fundamentada na responsabilidade objetiva. A teoria, dessa forma, parte do pressuposto de que a atuação do Estado envolve risco de dano, que lhe é inerente. Tal teoria foi reconhecida no Brasil a partir da Constituição Federal de 1946 e é adotada até os dias atuais, conforme se observa no art. 37, $\S 6^{\circ}$, da Constituição da Republica de 1988. A sua caracterização fica condicionada à conduta estatal, o dano e o nexo de causalidade entre conduta e o dano, tornando-se prescindível a demonstração de culpa.

Com efeito, tem-se que a Constituição vigente adota a teoria da responsabilidade civil objetiva da Administração, sob a modalidade de risco administrativo. Entretanto, conforme adverte MEIRELLES (2007, p. 654-655) o risco administrativo não significa que a indenização sempre será devida, pois não foi adotada a teoria do risco integral. Assim, por exemplo, a culpa exclusiva da vítima afasta a ilicitude do fato e fica excluída a responsabilidade da Fazenda Pública.

Importante, porém, é frisar que apesar de o art. $37, \S 6^{\circ}$ da $\mathrm{CR} / 88$ prever a responsabilidade objetiva do Estado em casos em que seus agentes, nessa qualidade, causarem danos a terceiros, tal dispositivo não deixou expresso se o caso se aplica também às condutas omissivas, tal como se dá na hipótese de suposta ausência/falha na fiscalização adequada da barragem do Fundão. Essa lacuna gera a necessidade de estudo específico, o que será feito no tópico a seguir. 


\subsection{Responsabilidade civil extracontratual do Estado por condutas omissivas}

Conforme afirmado supra, a teoria do Risco Administrativo, aplicada no Brasil, atribui o dever de responsabilizar ao Estado ou aqueles investidos indiretamente da prestação de serviços públicos (empresas delegatárias de serviço público) pelos danos que causarem a outrem, que decorram dessa prestação de serviços. Os elementos subjetivos (dolo ou culpa) somente serão aferidos para verificar eventual direito de regresso.

E, segundo esclarece a doutrina, o Estado pode causar danos à particulares por ação ou por omissão, acrescentado CARVALHO FILHO (2014, p. 571) que:

[...], quando a conduta estatal for omissiva, será preciso distinguir se a omissão constituiu, ou não, fato gerador da responsabilidade civil do Estado. Nem toda conduta omissiva retrata um desleixo do Estado em cumprir um dever legal; se assim for, não se configurará responsabilidade estatal. Somente quando o Estado se omitir diante do dever legal de impedir a ocorrência do dano é que será responsável civilmente e obrigado a reparar os prejuízos.

A responsabilidade civil do Estado por danos extracontratuais é objetiva, como regra, decorrente do preceito expresso contido no $\S 6^{\circ}$, art. 37, da Constituição da Republica, já examinada antes. Entretanto, a doutrina e a jurisprudência majoritária entendem que nos casos de danos causados em virtude de conduta omissiva do agente público, a entidade pública responde com fundamento na culpa civilista e não objetivamente, por entenderem que a teoria da responsabilidade objetiva se aplica apenas nos casos de ato comissivo. A conduta omissiva, justificam, não configura ato. Portanto, não se enquadra na regra constitucional. Há, contudo, a corrente, ainda minoritária, defensora do entendimento de que mesmo nos casos de conduta omissiva, o Estado responde objetivamente pelos danos gerados em virtude de omissão de agente, identificável ou não.

À título exemplificativo traz-se à colação posições de integrantes das duas correntes.

Da primeira corrente: Celso Antônio Bandeira de Mello, Diógenes Gasparini e Marçal Justen Filho. Com efeito, MELLO (2014, p. 1031) afirma que:

Caso o Poder Público não estivesse obrigado a impedir o acontecimento danoso, faltaria razão para impor-lhe o encargo de suportar patrimonialmente as consequências da lesão. Logo, a responsabilidade estatal por ato omissivo é sempre responsabilidade por comportamento ilícito. E, sendo responsabilidade por ilícito, é necessariamente responsabilidade subjetiva, pois não há conduta ilícita do Estado (embora do particular possa haver) que não seja proveniente de negligência, imprudência ou imperícia (culpa) ou, então, deliberado propósito de violar a norma que o constituía em dada obrigação (dolo). Culpa e dolo são justamente as modalidades de responsabilidade subjetiva. 
Dessa forma, a omissão não seria causa direta do dano, mas mera condição para sua ocorrência. Seguindo esse entendimento, não há como estabelecer um nexo causal entre a omissão estatal e o prejuízo, pois se o Estado não deu causa, não se lhe pode imputar a responsabilidade pelo dano. Surge, dessa maneira, a necessidade de se verificar a culpa do ente estatal, responsabilidade subjetiva.

GASPARINI (2007, p. 990) também se posiciona nesse sentido, defendendo a responsabilidade subjetiva em casos de omissão. O Estado indeniza apenas se tiver se omitido em comportamentos impostos por leis; quando há, assim, o dever legal de agir e se omite.

Argumenta JUSTEN FILHO (2014, p. 1339- 1343) que as hipóteses de dano derivado da omissão são as seguintes: aquelas em que uma norma prevê o dever de atuação e a omissão corresponde à uma infração de tal dever jurídico (considerado ilícito próprio) e aqueles em que a norma prescreve certo resultado danoso, o qual vem a se consumar em virtude da ausência da adoção das cautelas necessárias a tanto (tido como ilícito omissivo impróprio). Nesta última hipótese torna-se imperioso demonstrar que o atendimento ao dever de diligência teria conduzido ao impedimento da adoção das condutas aptas a gerar o dano. Nesse sentido, vejamos o julgado abaixo, proferido pelo Superior Tribunal de Justiça (STJ):

A conclusão exarada pelo Tribunal a quo alinha-se à jurisprudência deste Superior Tribunal de Justiça, orientada no sentido de reconhecer a legitimidade passiva de pessoa jurídica de direito público para figurar em ação que pretende a responsabilização por danos causados ao meio ambiente em decorrência de sua conduta omissiva quanto ao dever de fiscalizar. Igualmente, coaduna-se com o texto constitucional, que dispõe, em seu art. 23, VI, a competência comum para a União, Estados, Distrito Federal e Municípios no que se refere à proteção do meio ambiente e combate à poluição em qualquer de suas formas. E, ainda, o art. 225, caput, também da CF, que prevê o direito de todos a um meio ambiente ecologicamente equilibrado e impõe ao Poder Público e à coletividade o dever de defendê-lo e preservá-lo para as presentes e futuras gerações. (AgRg no AgIn 973.577/SP, $2^{\circ}$. T. Min. Relator Mauro Campbell Marques, j. 16.09.2008, DJe 19.12.2008).

Da segunda corrente: Hely Lopes Meirelles e José dos Santos Carvalho Filho.

CARVALHO FILHO (2014, p. 571) sustenta ser objetiva a responsabilidade do Estado nas condutas omissivas (dedicando tratamento unitário para as ações e as omissões), e o faz nos moldes do $\S 6^{\circ}$, art. 37, da CR/88, partindo-se da ideia de que o dispositivo mencionado não faz distinção entre condutas ativas e omissivas. Consequentemente, aduz que ao intérprete e ao aplicador do direito não cabe fazer distinções ou acréscimos que não estejam inseridos na lei, 
concluindo-se que a perquirição da culpa só se faz exigível nas ações de regresso do Estado contra o agente causador do dano.

De tal modo, com base na teoria do risco administrativo, deve-se apenas perquirir a relação de causalidade entre o ato omisso do agente e o dano sofrido por terceiro para comprovar a responsabilidade estatal, sendo esses elementos suficientes para responsabilizar o Estado pelo dano sofrido.

Acrescenta, ainda CARVALHO FILHO (2014, p. 572) que em razão de o elemento marcante da responsabilidade extracontratual do Estado ser a responsabilidade objetiva, não se lhe afigura correto afirmar que nas condutas omissivas incidiria a responsabilidade subjetiva. Argumenta, assim, que "quando se diz que nas omissões o Estado responde somente por culpa, não se está dizendo que incide a responsabilidade subjetiva, mas apenas que se trata de responsabilidade comum, ou seja, aquela fundada na culpa, não se admitindo então a responsabilidade sem culpa".

Da mesma forma, sustenta MEIRELLES (2007, p. 653) que o exame do $\S 6^{\circ}$, art. 37, da $\mathrm{CR} / 88$ revela que o constituinte estabeleceu para todas as entidades estatais e seus desmembramentos administrativos a obrigação de indenizar o dano causado a terceiros por seus servidores, independentemente da prova de culpa no cometimento da lesão, firmando, assim, o princípio objetivo da responsabilidade sem culpa pela atuação lesiva dos agentes públicos e seus delegados.

Nesse sentido, interessante é observar o julgado abaixo, do STF, que reconheceu a responsabilidade civil objetiva do Estado, em decorrência da omissão deste:

\begin{abstract}
Agravo regimental no recurso extraordinário com agravo. Administrativo. Estabelecimento público de ensino. Acidente envolvendo alunos. Omissão do Poder Público. Responsabilidade objetiva. Elementos da responsabilidade civil estatal demonstrados na origem. Reexame de fatos e provas. Impossibilidade. Precedentes. 1. A jurisprudência da Corte firmou-se no sentido de que as pessoas jurídicas de direito público respondem objetivamente pelos danos que causarem a terceiros, com fundamento no art. $37, \S 6^{\circ}$, da Constituição Federal, tanto por atos comissivos quanto por omissivos, desde que demonstrado o nexo causal entre o dano e a omissão do Poder Público. 2. O Tribunal de origem concluiu, com base nos fatos e nas provas dos autos, que restaram devidamente demonstrados os pressupostos necessários à configuração da responsabilidade extracontratual do Estado. 3 . Inadmissível, em recurso extraordinário, o reexame de fatos e provas dos autos. Incidência da Súmula ${ }^{\circ}$ 279/STF. 4. Agravo regimental não provido. (STF $1^{\text {a }}$ T ARE 754.778 Rel. Dias Toffoli. DJe de 19/12/2013).
\end{abstract}

Dessa forma, parece que a melhor orientação é a sustentada pela segunda corrente, visto que o art. $37, \S 6^{\circ}$, da Constituição da República, único que dispõe sobre a responsabilidade 
civil das pessoas de direito público e as pessoas de direito privado prestadoras de serviços públicos, não faz distinção entre ato comissivo e conduta omissiva.

A jurisprudência majoritária, porém, adota a teoria da responsabilidade subjetiva do Estado em caso de omissão. Nesse sentido é o acórdão do Supremo Tribunal Federal no Recurso Extraordinário 179.147, em que foi Relator o Ministro Carlos Velloso. Veja-se:

\begin{abstract}
I-A responsabilidade civil das pessoas jurídicas de direito público e das pessoas jurídicas de direito privado prestadoras de serviço público, responsabilidade objetiva, com base no risco administrativo, ocorre diante dos seguintes requisitos: a) do dano; b) da ação administrativa; c) e desde que haja o nexo causal entre o dano e a ação administrativa. II- Essa responsabilidade objetiva, com base no risco administrativo, admite pesquisa em torno da culpa da vítima, para o fim de abrandar ou mesmo excluir a responsabilidade da pessoa jurídica de direito público ou da pessoa jurídica de direito privado prestadora de serviço público. III- Tratando-se de ato omissivo do poder público, a responsabilidade civil por tal ato é subjetiva, pelo que exige dolo ou culpa, numa de suas vertentes, negligencia, imperícia ou imprudência, não sendo, entretanto, necessário individualizá-la, dado que pode ser atribuída ao serviço público, de forma genérica, a faute du service dos franceses. (STF - RE 179.147/SP. Relator Ministro Carlos Velloso, $2^{\mathrm{a}}$ Turma. Brasília, DF, 12 de dezembro de 1997. Divulgado no DJ de 27/02/1998).
\end{abstract}

Entretanto, é importante ressaltar que ainda que prevaleça o entendimento de que o Estado responde subjetivamente nos casos de conduta omissiva, tratando-se de danos ao meio ambiente, a responsabilidade do Estado será sempre objetiva, mesmo nos casos de conduta omissiva, é o que se sustentará no item seguinte.

\title{
3.3. A defesa ambiental e a responsabilidade civil do Estado por danos ambientais
}

Como sabido, é consagrado, em sede constitucional, o direito de todos ao meio ambiente ecologicamente equilibrado, sendo atribuído ao Poder Público juntamente com a coletividade o dever de protegê-lo, por tratar-se de bem de uso comum do povo.

Desta forma, afirma-se que o direito ao um meio ambiente ecologicamente equilibrado inclui-se entre os direitos fundamentais. A concretização desse direito é dever de todos, em especial, do Estado, compreendendo as funções legislativa, executiva e jurisdicional. A harmonia dessas três funções com a participação social é indispensável à manutenção da qualidade do meio ambiente e do desenvolvimento sustentável. Entretanto, o Estado Executivo tem sido omisso, inerte e irresponsável quanto ao seu dever de zelar pela efetivação do Direito ao meio ambiente. Ele próprio, por ação ou omissão tem contribuído para a geração de problemas ambientais. Nesse sentido alerta BARACHO JÚNIOR (1999, p. 257): 
A aposta no Estado como ente capaz de solucionar os atuais problemas ambientais nos parece já perdida. Seja porque o Estado é um dos responsáveis pela degradação da qualidade ambiental, seja porque o Estado não monopoliza as pretensões intersubjetivas de validade.

Segundo SARLET (2015, p 48) a defesa do meio ambiente pode ser enquadrada no rol dos direitos de terceira dimensão, também denominados de direitos da fraternidade ou de solidariedade, os quais trazem como nota distintiva o fato de se desprenderem da figura do homem- indivíduo como seu titular, destinando-se à proteção de grupos humanos, sendo caracterizados como direitos de titularidade coletiva ou difusa.

A Política Nacional de Meio Ambiente, prevista na Constituição de 1988, art. 225, e regulamentada pela Lei $n^{0} 6.93831 .8 .1981$, adotou a teoria da responsabilidade objetiva nos casos de danos ambientais (art. 14, § $\left.1^{\circ}\right)$.

Sustenta também a doutrina que a responsabilidade nos casos de danos ambientais, além de objetiva, é integral e solidária, chegando FERRAZ (1977, p. 320) a afirmar que a mesma ainda deve ser fundada na teoria do risco integral, mesmo nos casos de omissão causadora do dano. $\mathrm{O}$ autor acrescenta:

\footnotetext{
Não se pode pensar em outra malha senão a malha realmente apertada que possa, na primeira jogada da rede, colher todo e qualquer possível responsável pelo prejuízo ambiental. É importante que, pelo simples fato de ter havido a omissão, já seja possível enredar agente administrativo e particulares, todos aqueles que de alguma maneira possam ser imputados ao prejuízo provocado para a coletividade (FERRAZ, 1997, p. 320).
}

No tocante à solidarização nos prejuízos, alerta BARACHO JÚNIOR (1999, p. 321), que o dever de reparação deve ser imputado à todas as pessoas que possam ser identificadas, pouco importando se tiveram participação maior ou menor que outras na concretização do dano. Nesse sentido, inclusive, já se manifestou o Superior Tribunal de Justiça, quando do julgamento do Recurso Especial 37.354/93-SP, no qual proferiu decisão unânime, expressando o entendimento de que a responsabilidade por danos causados ao meio ambiente é solidária, alcançando os responsáveis direitos e indiretos pelo dano, ou ambos.

Nesse sentido, a responsabilidade por dano ambiental passa a ter dimensão de extrema relevância nos cenários social, econômico, político e jurídico por denotar, também, questão de sobrevivência humana. 


\section{Responsabilidade dos entes públicos pelos danos causados com o desastre ambiental em Mariana/MG}

A doutrina majoritária sustenta que a responsabilidade administrativa ambiental é objetiva, em razão do interesse público de preservação do meio ambiente e da necessidade de rápida reparação do dano, sendo tal responsabilidade calcada no risco integral, bem como no caráter solidário (BARACHO JÚNIOR, 1999, p. 321).

Tamanha é a importância da proteção do meio ambiente no ordenamento jurídico pátrio que a legislação atinente prescreve a necessidade imprescindível de licença ambiental pelos órgãos ou entidades públicas para o exercício de atividades potencialmente degradadoras do meio ambiente. A referida licença é um dos instrumentos mais eficazes na defesa dos recursos naturais e do equilíbrio ecológico.

Nesse sentido, esclarece TRENNEPOHL (2011, p. 17) que a Lei n. 6.938/1981, que instituiu a Política Nacional do Meio Ambiente, listou, entre os instrumentos disponíveis para a proteção do meio ambiente ecologicamente equilibrado, o licenciamento de atividades potencialmente poluidoras.

O art. 176 da Constituição da República de 1988 (CR/88) assegura a propriedade da União sobre as jazidas, em lavra ou não, e demais recursos minerais, apesar de garantir ao minerador a propriedade sobre os resultados da lavra; determinando, também a responsabilidade do governo em fiscalizar a atividade mineraria (art. 23, inciso XI, da CR/88). Assim, a defesa do meio ambiente é tratada como matéria de competência comum entre os entes federativos, acrescentando a norma constitucional que lei complementar fixará as normas para cooperação entre estes. Ainda, considerando que a referida lei complementar não foi editada até a presente data, (30.04.2018) a doutrina tende a defender a tese de que a competência para o licenciamento decorre da preponderância dos interesses (ambientais) envolvidos. Assim, prevalece a tese da magnitude do dano como elemento para estabelecer a competência para o licenciamento.

Ademais, conforme aponta TRENNEPOHL (2011, p. 23), "o fato de um empreendimento ou atividade estar em processo de licenciamento num determinado órgão ambiental não afasta o poder de polícia dos demais".

A Política Nacional de Segurança de Barragens (PNSB) prevê que o empreendedor é o responsável legal pela segurança da barragem. Diante disso, sustenta-se que a responsabilidade da mineradora Samarco, pelo desastre socioambiental ocorrido em MarianaMG é inquestionável e encontra-se justificada na legislação em vigor no País. 
Por outro lado, no que toca aos órgãos públicos, a Lei $n^{\circ}$. 12.334, de 20 de setembro de 2010, que dispõe sobre a Política Nacional de Segurança de Barragens, estabelece que a fiscalização da segurança das barragens compete aos órgãos ambientais integrantes do Sistema Nacional do Meio Ambiente - SISNAMA, criado pela Lei $n^{\circ}$ 6.938/1981), integrado por órgãos e entidades da União, dos Estados, do Distrito Federal e dos Municípios. O mesmo diploma legal ainda dispõe sobre a distribuição da fiscalização de segurança entre diversos órgãos, considerando a entidade que outorgou, concedeu ou autorizou, ou expediu a licença ambiental.

No tocante às barragens de rejeitos, portanto, a competência para fiscalizar a segurança é do órgão integrante do SISNAMA, compartilhada entre o IBAMA, o órgão ambiental estadual e até então ao Departamento Nacional de Produção Mineral - DNPM (Autarquia Federal que era vinculada ao Ministério de Minas e Energia). Importante, neste sentido, registrar que no ano de 2017, o DNPM foi extinto, e criada para substituí-lo a Agência Nacional de Mineração (ANM) pela Lei n. 13.575, de 26.12.2017 resultante da conversão da Medida Provisória n. 791/2017. A ANM é uma autarquia federal, vinculada ao Ministério de Minas e Energia, responsável pela gestão da atividade de mineração e dos recursos minerais brasileiros, exceto hidrocarbonetos e substâncias nucleares.

Além disso, atuam, subsidiariamente, a Agência Nacional de Águas (ANA), o Conselho Nacional de Recursos Hídricos e o Comitê de Bacia Hidrográfica. Em Minas Gerais, a Fundação Estadual do Meio Ambiente (FEAM), é a entidade estadual responsável pelo licenciamento ambiental das barragens de rejeito da Mineradora Samarco, entre outras.

O Instituto Nacional do Meio Ambiente - IBAMA, a Agência Nacional de Mineração, e a Fundação Estadual do Meio Ambiente (FEAM), são diretamente responsáveis pelo licenciamento e fiscalização das atividades das Mineradoras que tenham impacto na área ambiental. Tais órgãos/entidades, portanto, têm prerrogativa para expedir licenças ambientais e também para a gestão das emergências ambientais.

Em relação às duas barragens da Mineradora Samarco, a FEAM as classificava como de alto potencial de dano ambiental. Porém, segundo informações coletadas pelo Jornal Estado de Minas ${ }^{17}$, apesar da classificação no mais alto risco de dano ambiental, o empreendimento teve a condição de estabilidade assegurada por auditor da FEAM. De acordo com o inventário realizado pelo FEAM em 2014 no local, depois de estudos geotécnicos, hidrológicos e hidráulicos, de análises visuais, condições de construção e estrutura, o auditor do órgão garantiu

\footnotetext{
17 JORNAL ESTADO DE MINAS. Barragem que rompeu em Mariana era empreendimento de alto risco. Disponível em <https:/www.em.com.br/app/noticia/gerais/2015/11/06/interna_gerais,705086/barragem-querompeu-em-mariana-era-empreendimento-de-alto-risco.shtml $>$. Acesso em: 08 jan. 2018.
} 
a estabilidade física do maciço e também a hidráulica da barragem. O documento destacou não haver "naquele momento, risco iminente de rompimento."

Por outro lado, conforme mencionado acima, há comprovação de que documentos referentes ao processo de revalidação de uma das licenças ambientais da barragem de Fundão, indicavam que o Ministério Público Estadual havia solicitado, em 2013, como condicionantes para emissão da nova licença de operação (LO), a inclusão da análise de ruptura da barragem e a elaboração de plano de contingência em caso de riscos ou acidentes, especialmente em relação à comunidade de Bento Rodrigues, distrito do município de Mariana-MG.

Diante de tal contexto, é possível apontar que o rompimento da barragem em Mariana era previsível, tendo os órgãos públicos responsáveis pela licença e fiscalização deixado, no caso em exame, de tomar as medidas necessárias para evitar o desastre.

\section{Conclusão}

Ao longo da pesquisa, foram apontadas as causas e os danos diversos e de grandes proporções ocasionados pelo rompimento da barragem do Fundão. Passados dois anos desde a tragédia, a quantificação dos danos causados aos moradores afetados e à natureza, ainda não foi concluído. Acresce-se a isso, a impossibilidade de se delimitar a extensão de todos os danos e compensar os estragos irreversíveis ao patrimônio cultural e ao meio ambiente.

Durante o estudo foi possível apontar falhas da SAMARCO diretamente e indiretamente, da VALE S.A. e da australiana BHP BILLINTON BRASIL LTDA e também por parte dos órgãos do Estado, durante o processo de licenciamento e de físcalização da barragem do Fundão. Com efeito, os agentes, funcionários da União e do Estado de Minas Gerais, que exercem as funções de licenciar a atividade mineraria e de monitorar as atividades da SAMARCO e de monitorar a respectiva barragem de rejeitos, falharam na identificação e previsão da possibilidade de ocorrência de rompimento da barragem em exame, quando tinham o dever de agir para impedir ou tentar amenizar as ocorrências do dano iminente. Assim, a omissão configura infração.

Diante disso, torna-se imperioso reconhecer que a mineradora SAMARCO, embora causadora direta do dano, não é a única que deve ser responsabilizada pelo desastre ambiental, devendo também ser avaliada a responsabilidade por omissão dos agentes públicos na hipótese sob análise. 
A responsabilidade civil extracontratual do Estado, nos casos de danos ambientais, encontra-se pautada na responsabilidade objetiva e na teoria do risco, conforme regra expressa na Lei ${ }^{\circ} 6.938 / 1981$, art. $14, \S 1^{\circ}$.

No caso sob análise, restou, de fato, identificada a posição da União e do Estado de Minas Gerais, na condição de garantidores dos direitos fundamentais, inclusive o meio ambiente ecologicamente equilibrado, o que torna imperativo o reconhecimento do dever dos mesmos de indenizar no caso da tragédia da SAMARCO, na proporção das suas contribuições para os danos causados, visto que tinham o dever de adotar as providências necessárias para evitar a consumação dos danos ocorridos.

\section{Referências bibliográficas}

BARACHO JÚNIOR, José Alfredo de Oliveira. Responsabilidade civil por dano ao meio ambiente. Belo Horizonte: Del Rey, 1999.

BONAVIDES, Paulo. Direito constitucional. 5. ed. São Paulo: Malheiros, 1994.

BRASIL. Presidência da República Casa Civil. Constituição da República Federativa do Brasil de 1988. 1988. Disponível em: < http: http://www.planalto.gov.br/ccivil_ 03/constituicao/constituicao.htm> Acesso em: 07 de dez. 2017.

BRASIL. Lei no 6.938 de 31 de julho de 1981. Dispõe sobre a Política Nacional do Meio Ambiente, seus fins e mecanismos de formulação e aplicação, e dá outras providências. Presidência da República, Casa Civil, Subchefia para assuntos jurídicos. Disponível em < http://www.planalto.gov.br/ccivil_03/leis/L6938.htm> Acesso em: 07 de dez. 2017.

BRASIL. Lei no 7.347 de 24 de julho de 1985. Disciplina a ação civil pública de responsabilidade por danos causados ao meio ambiente, ao consumidor, a bens e direitos de valor artístico, estético, histórico, turístico e paisagístico (VETADO) e dá outras providências. Presidência da República, Casa Civil, Subchefia para assuntos jurídicos. Disponível em < http://www.planalto.gov.br/ccivil_03/leis/L7347orig.htm> Acesso em: 07 de dez. 2017.

CAHALI, Yussef Said. Responsabilidade civil do Estado. 3. ed. São Paulo: RT, 2007. 
CARVALHO FILHO, José dos Santos. Manual de direito administrativo. 27. ed. São Paulo: Atlas, 2014.

CRETELLA JÚNIOR, José. O Estado e a obrigação de indenizar. 2. ed. Rio de Janeiro: Editora Forense, 2002.

ENTERRÍA, Eduardo Garcia de. FERNÁNDEZ, Tomás-Ramón. Curso de Derecho administrativo. V. II. 9.ed. Madrid: Civitas, 2004.

FALECK, Diego. Desenho de sistemas de disputas e o rompimento das barragens de Fundão e Santarém: programa de indenização mediada (PIM). Revista da Defensoria Pública do Estado de Minas Gerais. Belo Horizonte, ano 1, n. 2, p. 13-15, nov. 2017.

FARIA, Edimur Ferreira. Curso de Direito administrativo positivo. 8. ed. Belo Horizonte: Fórum, 2015.

FERRAZ, Sérgio. Responsabilidade civil por dano ecológico. Revista de Direito Público. São Paulo, v. 49-50, 1997.

GASPARINI, Diógenes. Direito administrativo. 12.ed. São Paulo: Saraiva, 2007.

GORDILLO, Augustin. Tratado de Derecho Administrativo. 11. ed. V. I e II, Tomo II. Buenos Aires: Ediciones Macchi Lopes, 2013.

JUSTEN FILHO, Marçal. Curso de direito administrativo. 10.ed. São Paulo: Revista dos Tribunais, 2014.

MAZZILLI, Hugo Nigro. A Defesa dos Interesses Difusos em Juízo: Meio Ambiente, Consumidor, Patrimônio Cultural, Patrimônio Público e Outros Interesses. 22. ed. São Paulo: Saraiva, 2009.

MEIRELLES, Hely Lopes. Direito administrativo brasileiro. 33. ed. São Paulo: Malheiros, 2007. 
MELLO, Celso Antônio Bandeira de. Curso de direito administrativo. 31. ed. São Paulo: Malheiros Editores, 2014.

SARLET, Ingo Wolfgang. A Eficácia dos Direitos Fundamentais: Uma Teoria Geral dos Direitos Fundamentais na Perspectiva Constitucional. 12. ed. Porto Alegre: Livraria do Advogado, 2015.

TRENNEPOHL, Curt. Licenciamento ambiental. 4. ed. Niterói: Impetus, 2011. 


\title{
DA POSSIBILIDADE DE A ADMINISTRAÇÃO PÚBLICA RESOLVER POR CONTA PRÓPRIA PROBLEMAS DE INCONSTITUCIONALIDADE DAS LEIS
}

\author{
Maren Guimarães Taborda \\ Fundação Escola Superior do Ministério Público do Rio Grande do Sul - FMP
}

Guilherme Oliveira Weber

Fundação Escola Superior do Ministério Público do Rio Grande do Sul - FMP

\section{Resumo}

A Administração Pública, para realizar seus públicos fins, age pautada pelos princípios da legalidade, impessoalidade, moralidade, publicidade, eficiência e seus correlatos, como forma de satisfazer aos reclames das supremacia e indisponibilidade do interesse público. Se a Administração se submete a um rigoroso e necessário regramento público, pode ela própria dar cumprimento a uma lei manifestamente inconstitucional? Seguramente, não. Este artigo, pois, pretende fundamentar racionalmente essa resposta e apresentar como pode a Administração deixar de aplicar alguma lei inconstitucional antes de qualquer pronunciamento pelo Poder Judiciário em sede de controle de constitucionalidade.

Palavras-chave: Administração Pública, Legalidade, Moralidade, Publicidade, Lei inconstitucional.

\section{Abstract/Resumen/Résumé}

The Public Administration, in order to perform its public aims, acts guided by the principles of legality, impersonal management, morality, publicity, administrative efficiency and others, as a way for attending the supremacy and unavailability of public interest claims. If the Administration surrenders itself to a precise and mandatory public regulation, can itself execute an absolutely unconstitutional law? Surely, not. This article, therefore, intends to rationally ground that answer and point how may the Administration not execute and unconstitutional law before any constitutional review.

Keywords/Palabras-claves/Mots-clés: Public Administration, Legality, Morality, Publicity, Unconstitutional law. 


\section{Introdução}

No plano sociológico, o sistema da política torna disponível a comunicação de decisões coletivamente vinculantes, de modo que, para absorver a sua função social, a política deve organizar-se no "Estado", organismo central da política, que é o destinatário e o autor da comunicação política. A Administração é um subsistema da política - "um sistema social de comportamentos organizados" -, cujo agir consiste no fato de produzir e comunicar decisões que vinculam os destinatários. A Administração Pública (administração do sistema político que dispõe da legitimidade para produzir decisões vinculantes em confronto a todos os destinatários) descreve-se, então, como o "sistema social da distribuição de poder legítimo e formalizado". (TABORDA, 2016, p. 237; DE GIORGI, 2013, p. 121).

A Administração Pública, para realizar seus públicos fins, pauta suas ações, em sentido amplo, pelos princípios da legalidade, da impessoalidade, da moralidade, da publicidade, da eficiência e daqueles correlatos a estes. E assim o é não apenas porque está previsto na cabeça do art. 37, da Constituição da República, mas também como forma de satisfazer aos reclames da supremacia do interesse público sobre o privado e da indisponibilidade desse interesse público, bases da própria atividade administrativa e de onde surge um público e necessário regramento (BANDEIRA DE MELLO, 2012, pp. 55-56).

Ora, se a Administração Pública presta obediência a inúmeros princípios, que presidem seu agir, e se submete a um rigoroso e necessário regramento público, como forma de assegurar a supremacia do interesse público e atingir certas e determinadas finalidades públicas, pode ela dar cumprimento a uma lei manifestamente inconstitucional? Dito de outra forma, pode o Chefe do Poder Executivo, ele próprio, recomendar a seus subordinados a não aplicação de alguma lei inconstitucional antes de qualquer pronunciamento pelo Poder Judiciário em sede de controle concentrado ou difuso de constitucionalidade?

Considerado o controle de constitucionalidade no País, tido como híbrido em face da adoção de técnicas diversas (e até mesmo opostas) de fiscalização de constitucionalidade (TABORDA, 2014, p. 70), este estudo procura investigar em quais situações o Chefe do Executivo (em qualquer esfera de Poder) pode deixar de aplicar lei que entende inconstitucional e com quais argumentos. O ponto de observação é o caso concreto surgido no Município de Porto Alegre, a propósito da aprovação do Projeto de Lei n. 236/11, de 2012, oriundo da Câmara Municipal, que versava sobre a ampliação do prazo de parcelamento de dívidas de Imposto Sobre a Propriedade Predial e Territorial Urbana (IPTU) e Taxa de Coleta de Lixo (TCL), bem como sobre a alteração dos índices de juros e correção monetária. Aprovado o projeto na 
ocasião, o Prefeito Municipal vetou totalmente o projeto de lei em comento. O veto, contudo, foi derrubado pelo Legislativo Municipal e o projeto foi convertido na Lei Municipal de Porto Alegre n. 11.428, de 30 de abril de $2013^{1}$.

O Prefeito Municipal, após ouvir a opinião do órgão consultivo, a Procuradoria-Geral do Município, estabeleceu um canal de negociação com a Câmara para que a lei fosse anulada e, até que isso ocorresse efetivamente, decidiu deixar de dar execução à referida lei, que entendia inconstitucional, por vários argumentos, que podem (e devem) ser explicitados, por razões de coerência e integridade do sistema jurídico.

O tema do estudo é, portanto, controle de constitucionalidade feito pelo Poder Executivo - seu alcance, limites e possibilidades - situando-se na Teoria Constitucional, por que abrange questões de direito constitucional e de direito administrativo ou a premissa de que "o direito administrativo é o direito constitucional concretizado" (tese de Werner), já que a Constituição necessita da concretização operada pela Administração, a fim de realizar-se "a partir de baixo", sendo uma espécie de lei fundamental para a Administração e, simultaneamente, uma lei do cidadão (PEREIRA DA SILVA, 1996, p. 330).

O método de abordagem foi o indutivo, pois, a partir do caso concreto, discutem-se os princípios constitucionais do artigo 37, caput, da Constituição da República, que foram essenciais para justificar racionalmente a ação do Prefeito. O procedimento foi comparativo, fazendo-se a análise das normas em vigor e da posição da doutrina sobre o tema. As conclusões parciais vão sendo relatadas ao longo da exposição, e vêm articuladas ao final.

\section{A Jurisdição Constitucional como garantia da Constituição}

Desde os trabalhos de Kelsen, entende-se a jurisdição (ou justiça constitucional) como um sistema de garantias da Constituição ou um conjunto de medidas técnicas que têm por fim garantir o regular exercício das funções estatais, porque, na estrutura escalonada da ordem jurídica, as funções são, ao mesmo tempo, criação e aplicação do Direito ou etapas da formação da vontade coletiva. À Jurisdição e à Administração cabem as mesmas tarefas de concretização normativa: o modo como fazem isso e o valor último das decisões é que é diverso (KELSEN, 2003, pp.18-19; MIRANDA, 2002, p. 498). Daí, a tarefa da jurisdição constitucional é verificar

\footnotetext{
${ }^{1}$ Estabelece possibilidade de parcelamento de débitos de pessoas físicas ou jurídicas relativos ao Imposto sobre a Propriedade Predial e Territorial Urbana - IPTU - e à Taxa de Coleta de Lixo - TCL - no Município de Porto Alegre e dá outras providências.
} 
a conformidade à Constituição; a da jurisdição administrativa (que, no Brasil é feita através da Jurisdição comum), a legalidade da execução. Neste último caso, a inconstitucionalidade verificada é indireta, pois, de acordo com o princípio formal da legalidade da execução, "só pode haver ato de execução com base em uma lei”, diz Taborda (2014, p. 69). Controla-se, pois, externamente, a constitucionalidade do ato, e não a sua simples conformidade à lei.

No caso concreto ora discutido, o Prefeito Municipal, em suas razões de veto, aduziu sobre a inconveniência de se promulgar uma lei municipal que tenha por objeto a dilatação do prazo de pagamento das dívidas de IPTU e TCL e a modificação dos índices de juros e correção monetária - medidas que importariam em renúncia fiscal -, pois tais benefícios físcais configurariam concessão gratuita de benefícios em ano eleitoral, o que afrontaria à expressa disposição do artigo 73, parágrafo 10, da Lei n. 9.504/97. Argumentou, também, com uma provável inconstitucionalidade formal e material, bem assim ao desatendimento à Lei Orgânica do Município de Porto Alegre (art. 114, caput, e $\S 3$ ), porque foi concedido benefício fiscal sem prazo determinado de vigência; e à Lei de Responsabilidade Fiscal (Lei Complementar n. 101/00, art. 14), na medida em que a lei previa uma renúncia de receita sem a respectiva estimativa de impacto financeiro e orçamentário.

A inconstitucionalidade formal antes referida diz com o fato de que o projeto de lei foi proposto por membro do Poder Legislativo Municipal, sendo que, por versar sobre matéria tributária e orçamentária, a competência seria privativa do Chefe do Executivo, que é a autoridade a quem se acomete o comando superior da Administração Pública, estando a lei em apreço em afronta ao disposto nos artigos $5^{\circ}$, parágrafo único, $8^{\circ}, 10$, e 82 , incisos VII e XI, todos da Constituição do Estado do Rio Grande do Sul. A inconstitucionalidade material, de sua parte, decorre da violação aos princípios da moralidade e da eficiência (art. 37, caput, da Constituição da República).

Em face de tais considerações, a Lei Municipal de Porto Alegre n. 11.428/13 revelase material e formalmente inconstitucional, atentando, ainda, contra inúmeros dispositivos infraconstitucionais. Nesse contexto, é que é possível discutir se pode o Chefe do Poder Executivo determinar a não aplicação de uma lei dado que à Administração é compulsória a observância aos princípios da legalidade, da moralidade administrativa e da eficiência. Os argumentos da discussão envolvem esclarecer o que se entende por estes princípios, e decidir sobre o peso e a importância de cada um para a orientação da Administração no caso concreto. 


\section{Princípio da Legalidade: um argumento forte}

A Administração Pública deve se conformar ao preceito da legalidade. Segundo uma noção restritiva (mínima), o princípio da legalidade, afirma Eisenmann (1959, p. 54), “é uma relação de não-contrariedade, de não-incompatibilidade, ou positivamente, de compatibilidade" e isto significa apenas que a Administração está submetida à lei, devendo proceder de forma compatível com o sistema de normas legislativas. Sendo assim, pela primazia da lei, as autoridades administrativas têm a tarefa de executar as leis (MAURER, 2000, p. 45). Já, de acordo com uma noção mais larga, a relação de legalidade é uma relação de conformidade que tem duas direções: uma formal, em que a emissão do ato se desenvolve em conformidade com o esquema processual fixado em lei, e outra material ou substancial, em que o conteúdo do ato é modelado pela norma.

O princípio de conformidade, então, "postula a existência da regulamentação-modêlo como condição necessária para cada ato" (EISENMANN, 1959, p. 56), de modo que a ausência de regulamentação impede a prática do ato. Então, pelo princípio da compatibilidade, a Administração pode fazer tudo o que não seja, de uma forma ou de outra, proibido pela lei; o princípio da conformidade não permitirá que a Administração faça o que não lhe for permitido, de uma forma ou de outra, por essa mesma lei. Contrariedade é o desacordo com o disposto numa norma - plano da emissão ou do conteúdo - e, conformidade, a ideia de similitude ou reprodução - norma como modelo do ato administrativo -. A conformidade lógica ou racional é o que importa para a definição da legalidade. As relações de compatibilidade ou conformidade se suscitam quanto ao modo de produção dos atos e não só quanto ao fundo, sendo, então, requisitos de competência e forma.

Advém daí que as relações entre a lei e o desempenho da função administrativa se caracterizam pela polivalência, pois a legalidade administrativa pode tanto significar precedência da lei, preferência da lei, compatibilidade ou não-contradição (Vorrang des Gesetzes), quanto ser a exigência de que a prática de um ato pela Administração corresponda à sua previsão em lei vigente (princípio da reserva legal ou de conformidade - Vorbehalt des Gesetzes).

A vinculação da Administração à legalidade, por conseguinte, manifesta-se em dois vetores: a) sua competência funda-se juridicamente em textos legais emanados do Parlamento e não só nas instruções e comandos do príncipe; b) os direitos dos particulares surgem como limite externo à atividade da Administração e esta atividade está submetida ao controle judicial. (MAURER, 2000, p. 47; SÉRVULO CORREIA, 1987, p. 18) Pela primazia da lei (Vorrang 
des Gesetzes), então, a Administração está vinculada às leis existentes; pela reserva de lei (Vorbehalt des Gesetzes), a atuação da Administração deve ter um fundamento e uma autorização legal. (MAURER, 2000, p. 46). Essa visão de “duas” legalidades é fundamental nas sociedades complexas, uma vez que resta ultrapassada, por anacrônica, a visão de que a Administração Pública é mera aplicadora de leis e de que "direito seria apenas um limite para o administrador", como aduz Almiro do Couto e Silva (2015, p. 171).

Disso extrai-se que não pode a Administração, ao concretizar sua atuação pela prática de atos administrativos, adotar conduta que não encontre fundamento normativo, isto é, que o ordenamento jurídico não acoberte a pretensão estatal. Nesse toar, depende de fundamento e autorização legais, aqui, compreendidas como normas em conformidade com o ordenamento jurídico. Transpondo-se para o caso em análise, equivale a dizer que a Administração não pode cumprir lei manifestamente inconstitucional, na medida em que esse vício retira da lei a sua necessária eficácia.

Na jurisprudência dos Tribunais Superiores, é pacífico o entendimento de que qualquer Poder pode deixar de aplicar um ato normativo inconstitucional, se assim o considerar. A decisão judicial posterior só vem reconhecer a inconstitucionalidade que já existia. A nulidade é o aspecto menor que decorre da inconstitucionalidade - a inconstitucionalidade é existente e basta para a não aplicação, tanto que pode ser inconstitucional sem decretação de nulidade e pode haver declaração de inconstitucionalidade desta forma. A inconstitucionalidade é mais abrangente que a decretação de nulidade. As decisões parcialmente transcritas abaixo reforçam essa posição:

Os Poderes Executivo e Legislativo, por sua Chefia - e isso mesmo tem sido questionado com o alargamento da legitimação ativa na ação direta de inconstitucionalidade -, podem tão-só determinar aos seus órgãos subordinados que deixem de aplicar administrativamente as leis ou atos com força de lei que considerem inconstitucionais. (STF, RTJ 151/331, ADIN 221-DF, liminar, rel. Min. Moreira Alves)

Lei inconstitucional. Poder Executivo. Negativa de eficácia. O Poder Executivo deve negar execução a ato normativo que lhe pareça inconstitucional. (STJ, DJU 8.11.93, p.23521, Resp. 23.121/92, rel. Min. Humberto Gomes de Barros)

A questão em tela, nesse diapasão, é, na esteira do que já se abordou anteriormente, de reserva de lei, e daí se põe o problema do controle dos atos da Administração. Controle é a atividade de fiscalização exercida pelos cidadãos em relação aos atos estatais. Quando o ato é ordem geral e abstrata - lei em sentido material -, o controle é normativo e se cingirá a verificar 
se o ato em questão, ou mesmo uma lei, é adequado - em forma e conteúdo - à Constituição: é o controle de constitucionalidade. De outra parte, quando o ato estatal é ordem determinada, especial, a fiscalização restringir-se-á aos aspectos de legalidade (conformação do ato com o ordenamento jurídico em geral) e legitimidade (competência para a prática do ato), e o controle é administrativo.

Segundo a sistemática constitucional brasileira, o controle da constitucionalidade das leis (atos normativos) e atos administrativos em geral pode ser feito de forma difusa, pelo sistema de jurisdição única, ou concentrada, mediante as ações diretas de inconstitucionalidade. $\mathrm{Na}$ hipótese que ora se discute, torna-se uma questão tormentosa para a Administração Municipal reconhecer, de plano, a inconstitucionalidade de leis municipais válidas e deixar de aplicá-las, em face de sua vinculação à legalidade formal. À primeira vista, estaria proibida de fazê-lo, considerando o sistema de repartição de competências funcionais postos na Constituição da República. Por conseguinte, há que se verificar se o Executivo Municipal pode, no controle de constitucionalidade, sob o argumento da inconstitucionalidade, negar-se a dar cumprimento a uma dada decisão legislativa (lei ou ato normativo). Essa verificação só pode ser feita mediante um exame dos limites da atividade interpretativa, quando se trata de concretizar a Constituição.

Assim, afirma-se a possibilidade de o Chefe do Executivo usar tais princípios para fazer, por exemplo, controle de constitucionalidade interno da Administração Pública. No contexto de uma legalidade estrita, que valorize só normas, é necessária mudança da cultura administrativa, para que sejam sopesados por uma cultura de resultados - eficiência -, sob pena de excessivo formalismo e engessamento da Administração.

\section{A importância da eficiência}

A eficiência é realização eficaz de fins pré-dados, modo de realização ótima dos fins (noção formal que se traduz em uma relação meios-fins) e exigência de celeridade. Quando a Constituição da República fala em "Princípio da Eficiência", segundo o Superior Tribunal de Justiça - STJ, refere-se ao fato de que "a atividade administrativa deva orientar-se para alcançar resultado de interesse público" (Sexta Turma, 1996, RMS 5.590/95).

A doutrina brasileira, ao discutir o conteúdo do referido princípio, consubstanciou duas posições. A primeira é a de que a eficiência é nada mais do que manter, de forma integrada, sistema de controle interno com a finalidade de comprovar a legalidade e avaliar os resultados, quanto à eficácia e eficiência da gestão orçamentária, financeira e patrimonial dos órgãos da 
administração em geral - aí, incluídos os do Poder Judiciário, do Legislativo e das entidades públicas -. Significa dizer que nem precisaria estar explícito na Lei Maior porque a eficiência não é um princípio, mas uma finalidade da Administração. Neste sentido, todos os princípios que regem a atividade da Administração devem ser conjugados com o da boa administração (eficiência), que exige o exercício da função administrativa de forma eficiente e congruente. Daí que, segundo esta corrente, o princípio da eficiência só veio a explicitar o que sempre foi finalidade da Administração: garantir qualidade na atividade pública e na prestação dos serviços.

A segunda corrente reconhece a eficiência como "princípio" autônomo, cujo conteúdo é o de que o administrador deve laborar para produzir o efeito desejado, isto é, aquele que dá bom resultado, exercendo sua atividade sob o manto da igualdade, velando pela objetividade e imparcialidade. Se é assim, o referido princípio impõe à Administração a persecução do bem comum, por meio do exercício de suas competências, de forma imparcial, neutra, transparente, participativa, eficaz, sem burocracia e sempre em busca da qualidade, primando pela adoção de critérios legais e morais necessários para a melhor utilização possível dos recursos públicos, de maneira a evitar desperdícios e garantir a maior rentabilidade social.

O princípio da eficiência, portanto, dirige-se para a razão maior e fim do Estado: a prestação dos serviços sociais essenciais à população, visando a adoção de todos os meios legais e morais possíveis para a satisfação do bem comum. A posição doutrinária mais forte é a segunda, que entende ser a eficiência um princípio autônomo, que se estrutura como um dever da Administração, qual seja, aquele dever que estrutura "o modo como a Administração deve atingir seus fins e qual deve ser a intensidade da relação entre as medidas que ela adota e os fins que ela persegue" (ÁVILA, 2004, p. 428).

Mas eficiência nem sempre é escolher, dentre as várias opções possíveis, a menos dispendiosa: o que a eficiência determina é que a opção menos custosa deve ser adotada somente se as vantagens proporcionadas por outras opções não superarem o benefício financeiro. Dito de outro modo, a Administração tem o dever de escolher o meio mais econômico somente se restarem inalteradas a restrição dos direitos dos administrados e o grau de realização dos fins administrativos, mas este é o primeiro aspecto da eficiência. O segundo, diz respeito ao dever de promover o fim de modo satisfatório: mais do que adequação, a eficiência da Administração diz respeito à promoção, de forma satisfatória, dos fins em termos quantitativos, qualitativos e probabilísticos.

Decorre daí que escolher um meio para promover um fim, mas promover esse fim "de modo insignificante, com muitos efeitos negativos paralelos ou com pouca certeza, é violar o 
dever de eficiência administrativa". Por isso, pode-se compreender, por eficiência administrativa, a exigência de promover satisfatoriamente os fins, considerando "promoção satisfatória" aquela minimamente intensa e certa do fim.

Sob esse prisma, uma lei que, inconvenientemente ao interesse social, promova em pleno ano eleitoral, renúncia fiscal sem a fixação de prazo de vigência do benefício, bem como sem prever o impacto financeiro ou medidas de compensação financeira de tal renúncia de receita, não pode ser aplicada pela Administração Pública. Isso porque, caso fosse posta em execução, uma lei com esse conteúdo conduziria a realização de um fim - incentivar os contribuintes a regularizarem suas situações fiscais perante a Fazenda Municipal - de maneira absolutamente insatisfatória, uma vez que, ao contrário do que originaria pretendia, promoveria um verdadeiro incentivo à inadimplência.

\section{Da concretização da proteção à confiança}

O conceito de Estado Democrático de Direito envolve a presença de quatro elementos, a saber: garantias e direitos fundamentais, divisão das funções (das competências dos órgãos) estatais, legalidade da Administração Pública e proteção da boa-fé ou da confiança "que os administrados têm na ação do Estado, quanto à sua correção e conformidade com as leis" (COUTO E SILVA, 2015, p. 19).

Assim, no caso ora comentado, para além da legalidade, em qualquer de suas acepções, e da eficiência, a Lei Fundamental impõe que os atos da Administração se vinculem à moralidade, de modo que a autoridade não pode contrariar suas próprias orientações anteriormente emanadas, pois isso consiste em franca violação do princípio da proteção à confiança, que compõe a moralidade administrativa. Pelo princípio da proteção à confiança, não pode a Administração Pública modificar, em casos concretos, orientações firmadas para fins de sancionar, agravar a situação dos administrados ou denegar-lhes pretensões.

Isso é assim, porque a presença dos valores da lealdade, da honestidade e da moralidade aplicam-se necessariamente às relações entre a Administração e os cidadãos: se a Administração não exercer seu poder de forma a atender a confiança daquele com quem se relaciona, não se espera que os administrados se conduzam em observância às exigências éticas. A aplicação do princípio da proteção à confiança, isto é, sua absorção por determinada realidade jurídica, permite ao administrado recobrar a certeza (confiança de que não lhe será imposta uma prestação que só superando dificuldades extraordinárias poderá ser cumprida) de que a Administração não adotará uma conduta confusa e equívoca, que mais tarde lhe permita 
tergiversar suas obrigações, nem exigir do administrado mais do que aquilo que seja estritamente necessário para a realização dos fins públicos perseguidos. (GONZALEZ PEREZ, 1983, p. 73) Daí, o referido princípio visa à conservação de estados obtidos e dirige-se contra modificações jurídicas posteriores.

Assim, pode-se afirmar, em relação à aplicação do princípio da proteção à confiança, que a Administração Pública e o administrado hão de adotar um comportamento leal em todas as fases de constituição das relações até o aperfeiçoamento do ato e das possíveis conformações ao que haja nascido defeituoso. A lealdade no comportamento das partes na fase prévia de constituição das relações obriga a uma conduta clara, inequívoca, veraz, pelo que se rechaça qualquer pretensão que se baseie em uma conduta confusa, equívoca e maliciosa. Através do princípio da proteção à confiança, presume-se iuris tantum que os órgãos administrativos exercerão suas potestades de acordo com o Direito, presunção que não pode ser destruída por simples conjecturas.

Tal decorre de o princípio da moralidade abranger três dimensões, a saber: a) a "boafé", que no direito público se traduz pela tutela da confiança; b) a probidade administrativa (deveres de honestidade e lealdade); e c) a razoabilidade (expectativa de conduta civilizada, do homem comum, da parte do agente público). Daí que a moralidade abrange deveres e formula a exigência de comportamentos justificados por parte da Administração, tendo por consequências a proibição ao venire contra factum proprium; a proibição à inação inexplicável e desarrazoada, vinculada ao exercício de direito, que gera legítima confiança da outra parte envolvida; dever de conservação dos atos administrativos; dever de lealdade ao fator tempo (proibição ao exercício prematuro de direito ou dever ou retardamento desleal do ato e à fixação de prazos inadequados); dever de sinceridade objetiva e dever de informação, isto é, não omitir qualquer dado que seja relevante na descrição da questão controversa ou que possa auxiliar na sua resolução. (GIACOMUZZI, 2013, pp. 320-321)

Ora, se a Administração Pública, por suas próprias posição e prerrogativas, tem de pautar-se pelo respeito à legalidade e à moralidade administrativa, quando pratica atos que violam qualquer desses princípios, tem, logicamente, de promover a anulação de todos aqueles atos realizados em desconformidade. Na hipótese em discussão, em que o Poder Legislativo promulgou, após a derrubada do veto total aposto pelo Chefe do Poder Executivo, lei material e formalmente inconstitucional, bem assim que atenta contra outros atos normativos infraconstitucionais, sendo alguns de caráter nacional - isto é, oponíveis aos Poderes Políticos dos três níveis de Governo (SILVA, 2013, p. 495) -, lei essa que, por promover verdadeiro incentivo à inadimplência e conferir um tratamento favorecido aos contribuintes mais 
impontuais e recalcitrantes em arcar com suas obrigações tributárias, contravém ao disposto em prévios instrumentos normativos vigentes no ordenamento jurídico municipal e que, da mesma forma, dispõem sobre o parcelamento de dívidas de IPTU e TCL, é impositivo que a Administração impeça a prática de atos administrativos que se fundamentem em nessa lei, pois violariam as noções de lealdade e sinceridade para com os demais administrados que se submeteram a regime jurídico-tributário menos favorável.

Aplicando-se ao caso o princípio da proteção à confiança (que compõe a moralidade administrativa), chega-se à conclusão de que há uma presunção iuris tantum de que os órgãos administrativos exercerão suas potestades de acordo com o Direito, presunção que não pode ser destruída por simples conjecturas. Esta presunção decorre dos atributos dos atos administrativos, entendidos como "características que permitem afirmar que ele[s] se submete[m] a um regime jurídico administrativo ou a um regime jurídico de direito público". (DI PIETRO, 2013, p. 205)

Tais características subsumem-se em presunção de legitimidade, executoriedade, imperatividade e exigibilidade (BANDEIRA DE MELLO, 2013, p. 422), de modo que, em última instância, todos “os atos do Poder Público gozam da aparência e da presunção de legitimidade"(COUTO E SILVA, 2015, p. 47), o que têm justificado, muitas vezes, sejam os mesmos conservados no mundo jurídico ainda que apresentem vícios. Diante de tais características (atributos), os atos administrativos podem ser revogados ou anulados, e isto diz respeito à sua eficácia. Revogação é a supressão de um ato administrativo legítimo e eficaz, realizada pela Administração - e somente por ela - por não mais lhe convir a sua existência: "[t]oda revogação pressupõe, portanto, um ato legal e perfeito, mas inconveniente ao interesse público" (MEIRELLES, 1997, p.158).

Já anulação é a declaração de invalidade de um ato administrativo ilegítimo ou ilegal, feita pela própria Administração ou pelo Poder Judiciário. Baseia-se, portanto, em razões de legitimidade ou legalidade. De acordo com Bandeira de Mello (2013, 470):

valemo-nos do termo 'invalidade' para abranger quaisquer casos de desconformidade com o Direito. Evitamos usar com este fim o nomem juris 'anulação', já que tal palavra é correntemente manejada para o batismo de uma das espécies. [...] Invalidação é a supressão, com efeito retroativo, de um ato administrativo ou da relação jurídica dele nascida, por haverem sido produzidos em desconformidade com a ordem jurídica. 
Nesse sentido, é pacífica a tese de que, se a Administração praticou ato ilegal pode anulá-lo por seus próprios meios, consoante a Súmula n. 473, do Supremo Tribunal Federal STF:

A Administração pode anular seus próprios atos, quando eivados de vícios que os tornam ilegais, porque deles não se originam direitos; ou revogá-los, por motivo de conveniência ou oportunidade, respeitados os direitos adquiridos, e ressalvada, em todos os casos, a apreciação judicial.

Concluiu-se, então, que a lei municipal em questão não estava adequada ao ordenamento jurídico e constitucional pátrios, já que concedia, sem qualquer estudo prévio de impacto nas contas públicas, contrariando as informações previamente prestadas pelo Poder Executivo quando de diligências na fase legislativa, a pretexto de parcelamento de 80 meses de dívidas tributárias - já vigora parcelamento em 72 parcelas mensais - a toda e qualquer dívida de IPTU e TCL anterior à publicação da lei, remissão parcial de crédito tributário e anistia. $\mathrm{O}$ benefício fiscal importaria em impactante redução da arrecadação para os exercícios vindouros, sem contabilizar o alongamento injustificado da dívida por abarcar, inclusive, os parcelamentos regulares em vigor. A lei impediria também a integral execução do orçamento vigente, fazendo com que o Poder Executivo não pudesse honrar com compromissos assumidos e empenhados.

Por outro lado, merece ser salientado que a lei em testilha foi levada à aprovação em ano eleitoral, mas precisamente no dia 12 de dezembro de 2012, em conduta claramente vedada pelo art. 73, $\S 10$, da Lei n. 9.504/97, concedendo benefícios a determinados contribuintes, especialmente aos grandes e conhecidos devedores de IPTU e TCL da Capital Gaúcha. Dado o contexto temporal em que inserta a aprovação legislativa, é factível conceber-se a existência de desvio de poder e de finalidade e, por consequência, vício de inconstitucionalidade material: da leitura do ato normativo, viu-se que a pretexto de parcelamento, a lei previu remissão e anistia fiscal e nada mais.

Demais disso, é relevante ponderar que os benefícios em comento atingem apenas aqueles contribuintes com cadastro regular, pois o fato gerador de ambos os tributos incide sobre a regular propriedade imobiliária. Assim, não havia que se falar em justiça fisscal. Ademais, a lei hostilizada não alterou os encargos moratórios para os contribuintes, mas apenas e tão somente os expurga parcialmente para os contribuintes de IPTU e TCL, com dívidas lançadas até a entrada em vigor do diploma legal, pequenos ou grandes devedores. Ou seja, não houve pretensão de modificação dos encargos legais, mas, sim, de conceder favor físcal, que, 
às avessas, fará as vezes de incentivo ao não pagamento das dívidas consolidadas ou mesmo parceladas.

A referida lei, portanto, impunha ao Poder Executivo o dever de conceder, de forma indiscriminada, a inúmeros grandes e pequenos devedores, perdões fiscais que poderiam superar 50\% (cinquenta por cento) do montante total devido, autorizando parcelamentos desamparados de qualquer garantia e sem compromisso com o equilíbrio orçamentário. A aludida lei também não previu prazo máximo para a adesão do contribuinte inadimplente ao parcelamento/remissão/anistia. Ou seja, a lei analisada estimulava o contribuinte a optar pela discussão judicial com o Município, ainda que sem qualquer respaldo jurídico, uma vez garantido que, ao final da contenda, mesmo que sucumbente, se efetuasse o pagamento de sua dívida à vista, obteria uma redução de 50\% (cinquenta por cento) dos juros e correção monetária e restaria livre de toda e qualquer penalidade.

Houve, pois, patente violação aos princípios da moralidade e da eficiência. Igualmente, houve clara violação ao art. 140, da Constituição do Estado do Rio Grande do Sul, em face da inexistência de prazo determinado ao benefício, o qual deveria estar inserto no texto legal, por força do que dispõe o art. 113, $\S 3^{\circ}$, da Lei Orgânica do Município de Porto Alegre.

Ocorreu, no caso, vício formal de constitucionalidade na iniciativa da Câmara Municipal de propor lei de remissão e anistia, uma vez tratar-se de matéria orçamentária, de competência exclusiva do Poder Executivo. No mais, a lei agrediu a Constituição sul-riograndense, por provocar a ruptura da harmonia e independência entre os Poderes, impondo renúncia de receita ao Poder Executivo mediante o perdão fiscal e alongamento de dívidas tributárias consolidadas pelo lançamento definitivo. Houve, também, vício material de inconstitucionalidade, em razão do desvio de poder e finalidade da norma impugnada e do desrespeito aos princípios da proporcionalidade e da razoabilidade. Por fim, ao conceder anistia e remissão sem lei específica e sem prazo determinado, a norma em apreço acabou por violar preceitos das Leis Fundamentais Estadual e Federal e os princípios da isonomia, moralidade, legalidade e eficiência.

$\mathrm{O}$ ato normativo estudado, então, afrontou diretamente os artigos $5^{\circ}$, parágrafo único, 10, 82, VII, XI, 149, I, II, II, $\S 3^{\circ}$ e $\S 5^{\circ}$, V e 152, $\S 3^{\circ}$, todos da Constituição do Estado do Rio Grande do Sul, os quais referem ser atribuição precípua do Chefe do Poder Executivo Municipal, "face à autonomia política, administrativa e financeira do ente federado", exercer o superior comando da Administração Pública, obedecendo, em conjunto com os demais Poderes, aos princípios constitucionais que norteiam o Estado Democrático de Direito, resultando a agressão a tais norteamentos em evidente desrespeito às diretrizes constitucionais. 
Foi de acordo com o exercício dessa competência que o Constituinte estadual, de 1989, estabeleceu que "compete ao Governador, privativamente, enviar a Assembleia Legislativa os projetos de lei do plano plurianual, das diretrizes orçamentárias e dos orçamentos anuais, previstos na Constituição" (CE, art. 82, inciso XI) e que "não será admitido aumento na despesa prevista nos projetos de iniciativa privativa do Governador", e, por via de consequência, do Prefeito Municipal, em razão do princípio da simetria (CE, art. $8^{\circ}$ ), "ressalvado o disposto no artigo 152” (CE, art. 61, inciso I). Ora, se o Poder Legislativo não pode aumentar despesas nos projetos de iniciativa exclusiva do Chefe do Poder Executivo, não pode, contrario sensu, reduzir as fontes de receita, com a redução através de anistia e remissão de tributos já lançados e que compõem o orçamento anual, sob pena de lhe subtrair os meios necessários, previstos na lei orçamentária, à organização e funcionamento da administração municipal (CE, art. 82, VII).

Portanto, como, ao Poder Legislativo Municipal não compete reduzir receita de forma irresponsável - mesmo porque, se pudesse fazê-lo, o Executivo poderia ficar impedido de exercer sua função, que é administrar o Governo, uma vez que a previsão de receita e despesa está na lei orçamentária anual e é de iniciativa privativa do Chefe do Poder Executivo -, padecem os dispositivos em epígrafe de inconstitucionalidade formal, por vício de iniciativa. É corolário da independência dos poderes a liberdade de cada poder para realização dos serviços que lhe são inerentes, existindo a obrigação recíproca de não interferência entre as prerrogativas exclusivas de cada um (harmonia). (SILVA, 2013, p. 113) O princípio da iniciativa de leis está intimamente ligado ao princípio da independência entre poderes, tanto que a violação daquele atinge necessariamente a violação deste.

O reconhecimento da inconstitucionalidade, portanto, é imperativo, sob pena de conferir ao Legislativo o poder de inviabilizar o Executivo com a concessão de privilégios de forma irresponsável. Não é à toa que a Constituição da República prevê, em seus arts. $61, \S 1^{\circ}$, e 165, a iniciativa de leis reservadas ao Poder Executivo quando a matéria versa sobre administração e execução orçamentária; do contrário, haveria ruptura do sistema de divisão dos poderes.

Evidentemente que, se em determinadas situações é possível recorrer-se à renúncia fiscal, não por outra razão a Lei de Responsabilidade Fiscal exige que esta esteja acompanhada de estimativa do impacto orçamentário-financeiro, em seu artigo 14. O Tribunal de Justiça do Estado do Rio Grande do Sul - TJRS, quando diante de ações direta de inconstitucionalidade de leis municipais propostas pelo Poder Legislativo anistiando e remindo tributos sem qualquer análise do impacto nas contas públicas, sempre foi uníssono em reconhecer o vício formal 
constitucional, extirpando-as do ordenamento. (TJRS, ADI n. 70004467692, 2003; TJRS, ADI n. 598003671, 1999).

Da mesma forma, o TJRS tem reconhecido a inconstitucionalidade de leis de iniciativa do Poder Legislativo quando afrontam a independência e harmonia entre os poderes, concedendo benesses com repercussão orçamentária sem qualquer análise dos impactos ao Erário. Ocorreu, em ambos os casos, o chamado desvio ou excesso de poder legislativo com a usurpação pelo Legislativo das atribuições prescritas ao Executivo, impondo a este o ônus da ingovernabilidade. Há excesso de poder quando o Legislativo Municipal fixa diretrizes a respeito de norma financeira e orçamentária a pretexto de legislar sobre matéria tributária.

\section{Considerações finais}

O Executivo, por força da Lei de Responsabilidade Fiscal, Lei Complementar n. 101/00, para conceder qualquer benefício de natureza fiscal discriminatória, ante amplo planejamento e previsão legal, tem de promover uma elevação da carga tributária, de alíquota, de aumento de base de cálculo ou de criação de contribuição, de forma sempre a substituir aqueles valores renunciados. Se o legislador municipal concede anistia e remissão tributária de forma descomprometida com as medidas de compensação da receita renunciada, tem-se a ruptura da independência entre os Poderes, haja vista que é o Executivo quem suportará as consequências.

Não há como estabelecer um eficiente sistema de freios e contrapesos, caracterizador da harmonia entre os Poderes edilícios, sem um equilíbrio necessário à realização do bem da coletividade e, principalmente, sem que um Poder exerça, de forma responsável, as atribuições, faculdades e prerrogativas que lhe são conferidas pela Constituição e leis infraconstitucionais.

No presente caso, como se viu, a pretexto de realizar a justiça fiscal, o Poder Legislativo promulgou lei na qual não estava presente o interesse público, pois rigorosamente impôs ao Poder Executivo o ônus de suportar sozinho o perdão fiscal e o incentivo ao inadimplemento. Não promove tal lei a justiça fiscal, e, sim, impõe tratamento não isonômico entre o bom e o mau pagador, favorecendo este, ao contrário do bom senso comum, incentivando, de forma direta, o não cumprimento da norma tributária em prejuízo das contas públicas.

Neste tocante, a Constituição do Estado remete a organização do sistema tributário estadual às disposições da Constituição da República, às leis complementares e às Leis Orgânicas Municipais. E, nesse diapasão, vê-se que o ato normativo analisado neste artigo 
violou, expressamente, o que dispõe o art. 150, § 6 , da Constituição da República. Na esteira do que preconiza o Código Tributário Nacional, viu-se que a lei em comento não dispõe, de forma específica e exclusiva, sobre a remissão, estando em total desacordo com o art. 172, que conceitua, com exatidão, a lei especial que preconiza o art. 150, $\S 6^{\circ}$ do Estatuto JurídicoPolítico da República.

A Lei Municipal de Porto Alegre n. 11.428, de 30 de abril de 2013, por todos os argumentos jurídicos e fáticos aviados, é flagrantemente inconstitucional e, como tal, não pode ser aplicada pela Administração Pública. Assim, porque o Chefe do Poder Executivo possui o comando superior da Administração Pública, tem ele o poder de recomendar, através do comando normativo apropriado, a não aplicação da lei em comento nos casos concretos, uma vez que, das leis inconstitucionais, decorrem atos nulos, os quais não são capazes de gerar direitos.

É possível, portanto, ao Chefe do Poder Executivo, ao verificar ou constatar a evidente inconstitucionalidade de algum ato normativo ou lei, com fundamentos sólidos para tal, deixar de aplicá-lo, expedindo o comando apropriado (decreto) para que isso ocorra. Farta é a jurisprudência nesse sentido, como inicialmente exposto a título exemplificativo, havendo defesa na doutrina dessa prática, existindo precedentes como o julgamento do Min. Moreira Alves, relator da Representação n. 980, que tramitou no Supremo Tribunal Federal.

O principal a se considerar é que, na prática, é extremamente necessário que possa o administrador público assim agir, a fim de bem administrar, dentro dos ditames legais e constitucionais vigentes, sob pena de tornar inviável a aplicação das políticas públicas a que se propõe. É imprescindível que não se deixe o Poder Executivo obrigado a cumprir comando inconstitucional, colocando em risco a Administração e os administrados, simplesmente porque não houve a declaração judicial. A aplicação de lei inconstitucional pode trazer efeitos mais danosos do que a sua não aplicação, ainda que não declarada a inconstitucionalidade. Da vigência até a declaração existe um interregno de tempo em que não se pode aceitar cumprir normas em dissonância com a Constituição da República. Arrisca-se a dizer que se trata de um dever do administrador público não cumprir ditas leis.

Importante, nesse compasso, a compreensão da Constituição da República como norma fundamental de observância obrigatória a todos os entes da Federação, permitindo ao aplicador do direito resolver os problemas concretos que surgem dentro da ótica de hierarquia entre as leis e supremacia da Constituição na ordem jurídica. As normas infraconstitucionais não podem estar em desacordo com os valores e conteúdo da Lei Magna, devendo ser fiéis aos seus princípios e preceitos. Com essa concepção a fiscalização da constitucionalidade das 
normas infraconstitucionais pode e deve ser exercida por qualquer dos Entes da Federação, a fim de garantir eficácia e efetividade à aplicação das normas constitucionais à Administração Pública e, com isso, assegurar uma administração rentável e sustentável, tanto financeira como juridicamente e atingindo aos fins sociais a que deve se ater, não permitindo que normas inconstitucionais sejam aplicadas.

O papel do administrador público, aqui, encarnado nas funções de Chefe do Poder Executivo, é também garantir essa ordem constitucional. E, para que sua administração seja constitucionalmente baseada, visando ao bem comum, ao interesse público e ao bem administrar, é necessário legitimá-lo a determinar a não aplicação de regra em dissonância com a Constituição da República. A prática e o dia a dia do "administrar" exigem essa prerrogativa.

Trata-se de dever do administrador público, assim como de todos os administrados, a fiel observância ao texto maior de nosso País e, ao se sustentar a possibilidade de decidir pela aplicabilidade de normas inconstitucionais e assim determinar, nada mais se está fazendo, em última análise, do que enfatizar este dever de todos nós, cidadãos.

\section{Referências bibliográficas}

ÁVILA, Humberto. Sistema Constitucional Tributário. São Paulo: Saraiva, 2004.

BANDEIRA DE MELLO, Celso Antônio. Curso de Direito Administrativo. 30 ed. rev. e atual. São Paulo: Malheiros, 2013.

COUTO E SILVA, Almiro. O Princípio da segurança jurídica no direito público brasileiro e o direito da Administração Pública de anular seus próprios atos administrativos: o prazo decadencial do art. 54 da Lei de Processo Administrativo da União (Lei 9.784/19990). Conceitos Fundamentais do Direito no Estado Constitucional. São Paulo: Malheiros, 2015.

DE GIORGI, Raffaelle. A Administração Pública na Sociedade Complexa. Revista da Faculdade de Direito da FMP, n. 08. Porto Alegre, 2013.

DI PIETRO, Maria Sylvia Zanella. Direito Administrativo. 26 ed. São Paulo: Atlas, 2013. 
EISENMANN, Charles. O Direito administrativo e o princípio da legalidade. Revista de Direito Administrativo, Rio de Janeiro, v. 56, pp. 47-70, abr. 1959.

GIACOMUZZI, José Guilherme. A Moralidade Administrativa e a Boa-fé da Administração Pública. 2 ed. São Paulo: Malheiros, 2013.

GONZALEZ PEREZ, Jesus. El principio general de la buena fe en el derecho administrativo. Madrid: Civitas, 1983.

KELSEN, Hans. Jurisdição Constitucional. São Paulo: Martins Fontes, 2003.

MAURER, Harmut. Elementos de Direito Administrativo Alemão. Porto Alegre: Sérgio Fabris Editor, 2000.

MEIRELLES, Hely Lopes. Direito Administrativo Brasileiro. 22 ed. São Paulo: Malheiros, 1997.

MIRANDA, Jorge. Teoria do Estado e da Constituição. Rio de Janeiro: Forense, 2002.

PEREIRA DA SILVA, Vasco Manuel Pascoal Dias. Em Busca do Acto Administrativo Perdido. Coimbra: Almedina, 1996.

PORTO ALEGRE, BRASIL. Lei $\mathbf{n}^{\mathbf{0}} \mathbf{1 1 . 4 2 8}$, de 30 de abril de 2013. In:

http://www2.portoalegre.rs.gov.br, acessado em 04 de maio de 2018.

SÉRVULO CORREIA, José Manuel. Legalidade e Autonomia Contratual nos Contratos Administrativos. Coimbra: Almedina, 1987.

SILVA, José Afonso. Curso de Direito Constitucional Positivo. 36 ed. rev. e atual. São Paulo: Malheiros, 2013.

TABORDA, Maren G. Entre morcegos e beija-flores: reflexões críticas sobre a jurisdição constitucional no Brasil. Direito \& Justiça: Revista de Direito da Pontifícia Universidade Católica do Rio Grande do Sul. Vol 40, n.1, p. 1-120, janeiro/junho 2014, pp. 65-83. 
TABORDA, Maren G. Administração fiscal na sociedade complexa: o caso da constituição dos créditos não tributários no Município de Porto Alegre. In: GESTA LEAL, R., GAVIÃO FILHO, A. (org.) Coleção tutelas à efetivação de direitos indisponíveis. Porto Alegre: FMP, 2016, pp.235-264.[recurso eletrônico]. http://www.fmp.edu.br/serviços/285/publicacoes, acessado em 04 de maio 2018. 


\title{
DISCUSSÕES SOBRE A CONFORMIDADE CONSTITUCIONAL DA LEI BRASILEIRA DE PARCERIA PÚBLICO-PRIVADA
}

\author{
Mateus Eduardo Siqueira Nunes Bertoncini \\ Centro Universitário Curitiba - UNICURITIBA \\ Vinícius Rafael Presente \\ Centro Universitário Curitiba - UNICURITIBA
}

\begin{abstract}
Resumo
Analisar o instituto da parceria público-privada (PPP) e apresentar os debates que se formaram após a sanção da Lei ${ }^{0}$ 11.079/2004 a respeito de sua constitucionalidade, são os principais objetivos do presente artigo. Por meio de uma investigação que parte da bibliografia existente sobre o tema e empregando-se o método dedutivo, serão realizadas breves considerações a respeito do conceito de serviço público e de obra pública, haja vista que a parceria públicoprivada é um dos instrumentos de delegação de sua execução à particular.
\end{abstract}

Palavras-chave: Parceria público-privada; constitucionalidade; concessão; serviço público; obra pública.

\begin{abstract}
Resumen/Résumé
Analyze the Institute of public-private partnership (PPP) and introduce the debates that take place after the sanction of law 11,079/2004, regarding your constitutionality, are the main objectives of this article. Through an investigation that part of the existing literature on the subject, through the deductive method, will be carried out brief considerations about the concept of public service and public work, the public-private partnership is one of the your delegation instruments implementing particular.
\end{abstract}

Keywords/Palabras-claves/Mots-clés: Public-private partnership; constitutionality; concession; public service; public works. 


\section{Introdução}

O instituto da parceria público-privada foi inserido no ordenamento jurídico brasileiro por meio da Lei $\mathrm{n}^{\mathrm{o}} 11.079$, de 30 de dezembro de 2004, e constitui espécie de concessão de serviço público ou obra pública, com algumas particularidades que a diferencia das concessões disciplinadas na Lei $\mathrm{n}^{\circ} 8.987$, de 13 de fevereiro de 1995 . Os benefícios conferidos ao parceiro privado, ao financiador da parceria e a necessidade de contraprestação pecuniária por parte da Administração Pública são características não previstas na Lei Geral das Concessões.

É em razão dessas vantagens que a análise da (in)constitucionalidade do diploma legal instituidor das PPP's vem sendo fomentada. Os debates sobre a conformidade com a Constituição tiveram início logo após a sanção da Lei da PPP, através de questionamento dirigido pela Comissão de Precatórios da Ordem dos Advogados do Brasil - São Paulo ao conselho daquela seccional. $\mathrm{A} \mathrm{OAB} / \mathrm{SP}$, por sua vez, submeteu o tema à parecer do professor Kiyoshi Harada, que concluiu pela inconstitucionalidade de alguns dispositivos da lei. A conclusão de inconstitucionalidade é compartilhada por outros administrativas, dentre os quais se destaca Celso Antônio Bandeira de Mello.

Há, também, autores que defendem a constitucionalidade da Lei da PPP, como, dentre outros, Fernando Vernalha Guimarães e Gustavo Binenbojm. Existem argumentos que sustentam os dois entendimentos, motivo pelo qual a doutrina tem se dedicado à análise da constitucionalidade dos dispositivos da Lei $\mathrm{n}^{\circ}$ 11.079/2004.

A discussão sobre a constitucionalidade da aludida Lei, até esse momento - problema central da pesquisa -, permanece no campo acadêmico e doutrinário, posto que não foi submetida à julgamento perante o Supremo Tribunal Federal, motivo pelo qual ainda não existe no direito brasileiro conclusão sobre essa importante matéria.

Sem pronunciamento definitivo da Corte Constitucional, o tema continuará passível de discussões e debates, com reflexos sensíveis na ordem econômica e na prestação de serviços públicos. Nessa toada, o artigo analisará de forma concisa o instituto da parceria públicoprivada e cuidará brevemente dos conceitos de serviço público e de obra pública, para, em seguida, apresentar os principais argumentos da controvérsia, a fim de contribuir com o debate a respeito do tema central, que pode ser desdobrado em três problemas específicos de pesquisa: (1) A Lei 11.049/2004 - lei ordinária - poderia estabelecer garantias ao parceiro privado pela Administração Pública, sem ferir o disposto no art. 163, inc. III, da CF? (2) O Fundo Garantidor de Parcerias Público Privadas é compatível com o art. 100 da Constituição de 1988 e com os princípios constitucionais da igualdade, da impessoalidade e da moralidade? (3) É possível a 
adoção de mecanismos privados (arbitragem) para dirimir conflitos decorrentes do contrato de parceria, em especial quando o litígio envolver a Administração Pública?

A exposição não pretende ser exaustiva, nem esgotar todos os argumentos que sustentariam eventual conclusão pela constitucionalidade ou pela inconstitucionalidade total ou parcial da Lei n ${ }^{\circ} 11.079 / 2004$, inclusive porque não haveria espaço para tanto. Diversamente, a pesquisa visa a fomentar o tema e a apontar caminhos quanto aos questionamentos acima definidos, inclusive para futuros estudos que se pretende empreender sobre a matéria.

A partir de pesquisa bibliográfica, empregando-se o método dedutivo, analisar-se-á o tema intitulado "Discussões sobre a conformidade constitucional da Lei Brasileira de Parceria Público-Privada".

\section{O instituto da parceria público-privada}

A parceria público-privada é a modalidade que mais recentemente se introduziu no ordenamento jurídico brasileiro a respeito de concessão de serviço público ou de obra pública, que foi instituída pela Lei no 11.079/2004. Além das disposições do diploma instituidor, aplicase à PPP alguns dispositivos de outras normas que regulamentam as concessões, a saber os artigos 21, 23, 25 e 27 a 39 da Lei $n^{\circ} 8.987 / 1995$ e o art. 31 da Lei $n^{\circ}$ 9.074/1995. Tendo em vista que a Lei da PPP apresenta previsões que lhe são próprias, conferindo à modalidade particularidades que a diferenciam das concessões disciplinadas na Lei $n^{\circ} 8.987 / 1995$, pode-se dizer, então, que a PPP é uma modalidade especial de concessão, ao passo que aquelas que obedecem ao regime da Lei $n^{\circ} 8.987 / 1995$ podem ser chamadas de concessões gerais.

Dentre as características que são próprias da parceria público-privada pode-se destacar, dentre as previsões da Lei $\mathrm{n}^{\circ}$ 11.079/2004, aquelas que tratam do valor mínimo para o contrato de parceria público-privada, que é de $\mathrm{R} \$ 10$ milhões ${ }^{1}$, seu prazo de duração (no mínimo de 5 anos e máximo de 35 anos), as garantias de adimplemento previstas em favor do parceiro privado e a existência de contraprestação pecuniária, parcial ou integral, por parte do Poder Público.

O conceito de parceria público-privada é assim construído por Fernando Vernalha Guimarães:

\footnotetext{
${ }^{1}$ A redação original da Lei n ${ }^{\circ} 11.079 / 2004$ previa como valor mínimo para celebração do contrato de parceria público-privada o valor de R\$ 20 milhões. A recentíssima Lei n ${ }^{\circ} 13.529$, de 4 de dezembro de 2017, que converteu em lei a Medida Provisória $n^{\circ} 786$, de 12 de julho de 2017, alterou a redação do art. $2^{\circ}, \S 4^{\circ}$, I da Lei $n^{\circ} 11.079 / 2004$ e reduziu o valor mínimo para $\mathrm{R} \$ 10$ milhões.
} 
Em largas linhas, poderia se dizer que, sob o modelo trazido pela Lei n. 11.079/2004, as parcerias público-privadas configuram contratos administrativos de prestação de serviços, com ou sem delegação de serviço público, podendo envolver outras atividades integradas, cuja remuneração do parceiro privado esteja composta parcial ou integralmente por contraprestação pública (pecuniária ou não), a ser provida a partir da disponibilização do serviço em condições de fruição. (GUIMARÃES, 2013, p. 19)

Portanto, a parceria público-privada consiste em delegação efetuada pelo Poder Público ao particular, de prestação de serviço público, de execução de obra pública ou de ambas, que se formaliza por meio de contrato administrativo, precedido de licitação, e admite, para remuneração do particular, além do pagamento da tarifa pelo usuário, contraprestação financeira bancada pela Administração Pública.

Existem duas modalidades de parceria público-privada: a patrocinada e a administrativa. A modalidade patrocinada, em linhas gerais, se assemelha à concessão de que trata a Lei Geral de Concessões (Lei no 8.987/1995). Elemento principal da distinção da modalidade patrocinada de PPP da concessão geral está na forma de remuneração do parceiro privado, pois além do pagamento de tarifa pelos usuários, referida remuneração é acrescida de contraprestação pecuniária devida pela Administração, que ordinariamente será de até $70 \%$ (setenta por cento) do valor do contrato, salvo hipótese de autorização legislativa para que este percentual seja maior.

Já a modalidade administrativa é conceituada pela lei como "[...] o contrato de prestação de serviços de que a Administração Pública seja a usuária direta ou indireta, ainda que envolva execução de obra ou fornecimento e instalação de bens" (art. $2^{\circ}, \S 2^{\circ}$ da Lei 11.079/2004). A lei ao atribuir à Administração Pública a qualidade de usuária do serviço impõe a ela o pagamento integral da remuneração do contratado, pois no regime de concessão quem remunera o serviço prestado é o usuário ${ }^{2}$.

Ponto de destaque na Lei $n^{\circ} 11.079 / 2004$ são as garantias e os mecanismos de adimplemento de obrigações assumidos pela Administração Pública, conferidos aos particulares, ou seja, ao parceiro privado e ao financiador da parceria, tema da pesquisa.

Vale registrar, desde logo, que é em razão dessas garantias e benefícios que residem as principais críticas quanto a não conformidade da Lei da PPP à Constituição de 1988. Além dos argumentos jurídicos, a discussão é permeada pelo elemento ideológico. Bandeira de Mello,

\footnotetext{
${ }^{2}$ Celso Antônio Bandeira de Mello chega a chamar a modalidade administrativa da parceria público-privada de "falsa concessão", pois "o que a lei visa, na verdade, por meios transversos, não confessados, é a realizar um simples contrato de prestação de serviços - e não uma concessão -, segundo um regime diferenciado e muito mais vantajoso para o contratado que o regime geral" (MELLO, 2013, p. 801).
} 
por exemplo, classifica as PPP's como “crème de la crème do neoliberalismo, pelo seu apaixonado desvelo na proteção do grande capital e das empresas financeiras” (MELLO, 2013, p. 789).

Talvez o elemento ideológico seja o mais importante nessa discussão - e não propriamente a questão jurídica -, pois é ele que define as escolhas da sociedade, com impacto natural na ordem jurídica. O que está em jogo, em última análise, é o tipo de Estado que se quer para o Brasil do século XXI: o Estado Social, originalmente pretendido pela Constituição de 1988, ou o Estado neoliberal, influenciado pelo capitalismo global, que tudo transforma ou quer transformar em mercadoria, inclusive os serviços públicos asseguradores de direitos fundamentais da população. É evidente que o direito desempenha relevante função nessa escolha, delineando o perfil do Estado.

Retomando à análise dos elementos que qualificam a parceria público-privada como concessão especial, destacam-se as seguintes previsões trazidas pela Lei ${ }^{\circ} 11.079 / 2004$ : i) o prazo contratual de no mínimo 5 e no máximo de 35 (art. $5^{\circ}$, II); ii) as garantias para pagamento da obrigação contraída, previstas no art. $8^{\circ}$, como a previsão de vinculação de receita da administração (inciso I), a instituição de fundo especial (inciso II), contratação de segurogarantia com seguradora não controlada pelo poder público (inciso III), garantia prestada por instituição ou organismo financeiro não controlada pelo poder público (inciso IV), ou, ainda, a criação de empresa estatal criada para garantir esses pagamentos (inciso V); iii) a possibilidade de que os conflitos oriundos dos contratos de PPP sejam resolvidos por mecanismos privados, como arbitragem (art. 11, III); iv) para pagamento da contraprestação devida a administração poderá utilizar quaisquer um dos meios dispostos no art. $6^{0}$; v) atualização automática dos valores, sem necessidade de homologação pela administração (art. $5^{\circ}, \S 1^{\circ}$ ); e vi) previsão de penalidades à administração em caso de inadimplemento (art. $5^{\circ}$, II).

Por sua vez, as garantias aos financiadores do parceiro privado estão previstas nos incisos I, II e III do $\S 2^{\circ}$ do art. $5^{\circ}$. Em linhas gerais, é possível a transferência do controle acionário da sociedade de propósito específico para o financiador, a possibilidade de emissão de empenho em favor do financiador e a legitimidade do financiador em receber indenização pela extinção antecipada do contrato, além de poder receber pagamentos do fundo garantidor ou da empresa estatal garantidora das parcerias público-privadas criados para esta finalidade.

Para celebração do contrato de parceria é necessária a constituição de sociedade de propósito específico (SPE), nos termos do art. $9^{\circ}$ da Lei da PPP e será ela a responsável por implantar e gerir o objeto do contrato. A SPE pode assumir a forma de companhia de capital aberto, com valores mobiliários negociados no mercado. Nesse caso, é vedado à Administração 
Pública possuir a maioria do capital volante da sociedade, a não ser que as ações tenham sido adquiridas por instituição financeira controlada pelo Poder Público, em casos de inadimplemento do contrato de financiamento.

A Lei $n^{0} 11.079 / 2004$, dispõe sobre as diretrizes do contrato de parceria em seu art. $4^{\circ}$, dentre estas destaca-se o inciso VI, que institui como diretriz a repartição objetiva de riscos entre as partes. Nesse sentido, o art. $5^{\circ}$, III da Lei destaca que "a repartição de riscos entre as partes, inclusive os referentes a caso fortuito, força maior, fato do príncipe e álea econômica extraordinária". Há quem defenda ser incabível onerar o particular por decorrência do fato do príncipe, mas que é preciso cuidado com o que se classifica como fortuito, pois "nesta tipologia não se poderia incluir o insucesso na estimativa quanto ao afluxo de usuários do serviço ou seu superveniente declínio, sob a arguição, sob a arguição de que sobrevieram causas fortuitas para determinar tal resultado" (MELLO, 2013, p. 806).

A licitação que precede a celebração do contrato de parceria será sempre na modalidade concorrência, com adoção do procedimento previsto na Lei ${ }^{\circ} 8.666$, de 21 de junho de 1993, sendo autorizada a inversão de fases. Podem ser utilizados como critério de julgamento: menor tarifa, menor tarifa combinado com melhor técnica, menor contraprestação a ser paga pela Administração Pública ou menor contraprestação a ser paga pela Administração Pública combinado com melhor técnica. A forma de apresentação das propostas será definida em edital, sendo admitida apresentação escrita em envelopes lacrados ou propostas escritas seguidas de lances a viva voz.

O edital, cuja minuta deve ser apresentada em consulta pública, deve obedecer, no que couber, as disposições da Lei $n^{\circ} 8.987 / 1995$, que tratam sobre recusa de proposta inexequível, preferência, em igualdade de condições, das empresas brasileiras, as disposições sobre participação de consórcios e a previsão de ressarcimento com gastos de estudos e projetos.

É imperioso que o objeto da parceria tenha sido previsto no plano plurianual e as despesas estejam compatíveis com o que determina a Lei de Responsabilidade Fiscal (Lei Complementar $\mathrm{n}^{\mathrm{o}} 101$, de 4 de maio de 2000).

No âmbito da União, a Lei da PPP autoriza a criação do Fundo Garantidor de Parcerias Público-Privadas (FGP), de que podem participar também autarquias, fundações públicas e empresas estatais, cujo valor limite pode atingir R\$ 6 bilhões (art. 16). O FGP será gerido, administrado e representado por instituição financeira controlada (direta ou indiretamente) pela União.

A instituição da parceria público-privada no ordenamento jurídico brasileiro sofreu duras críticas, mas também elogios. Isso porque a existência de mais mecanismos cujo objetivo 
seja diminuir o feixe de atividades desempenhadas pelo Estado ao transferir à iniciativa privada a execução de serviço ou de obra pública, traz à tona o debate político sobre a dimensão da atuação estatal e o problema do seu tamanho e financiamento, resgatando a discussão sobre a oposição entre o Estado Social e o Estado Liberal.

\begin{abstract}
Parceria público-privada é assunto quase sempre ideológico, dada polarização que, não sem razão, provoca. Existem desde os exaltadores desta solução às insuficiências do modelo de concessões, para dar conta dos desafios de construção e disposição de infraestrutura, ante ao comprometimento dos recursos públicos; até os que enxergam tal solução jurídica do ponto de vista crítico, inserindo-a em um contexto maior de "desmonte" estatal. (NOHARA, 2014, p. 187)
\end{abstract}

Vale a transcrição integral do excerto já reproduzido anteriormente, de uma nota de rodapé da obra de Bandeira de Mello, na qual o jurista registra, de maneira nítida e contundente, sua opinião a respeito da introdução da PPP no direito brasileiro:

Trata-se de instituto controvertido, forjado na Inglaterra, ao tempo da Sra. Tatcher, e
acolhido entusiasticamente pelo Banco Mundial e pelo Fundo Monetário Nacional no
cardápio de recomendações aos subdesenvolvidos. A “parceria público privada", que
foi jucundamente auspiciada pelo partido governista - outrora comprometido com os
interesses da classe trabalhadora, e hoje ponta-de-lança das aspirações dos banqueiros
-, constitui-se na crème de la crème do neoliberalismo, pelo seu apaixonado desvelo
na proteção do grande capital e das empresas financeiras. Nem mesmo o Governo do
Sr. Fernando Cardoso, em despeito de sua álacre submissão aos ditames do FMI,
ousou patrociná-la, talvez por uma questão de decoro. (MELLO, 2013, p. 797).

A menção ao governo FHC se deve ao fato de o que presidente Fernando Henrique Cardoso vetou o art. 25 da Lei Geral das Concessões, dispositivo que visava a introduzir, já naquela época, o que hoje se conhece como modalidade patrocinada de parceria público-privada (BINENBOJM, 2005, p. 161).

Ainda que de modo sintético se tenha discorrido sobre as previsões e inovações trazidas pela Lei n ${ }^{\circ} 11.079 / 2004$, antes de se adentrar no âmago da pesquisa, faz-se necessário cuidar do objeto das parcerias público-privadas: o serviço público e a obra pública, categorias não apenas relacionadas à atividade econômica do Estado, bem assim à concretização de direitos fundamentais.

\title{
3. Breves considerações sobre o serviço público e a obra pública
}

A noção de serviço público remete às atividades que ao Estado se impõe, em razão da importância e da relevância para vida dos administrados. O Poder Público, portanto, coloca à 
disposição da população determinadas atividades que julga necessárias para assegurar direitos fundamentais dos administrados. A partir de uma decisão política, a lei que expressa essa escolha subtrai a possibilidade de que os particulares explorem economicamente essas atividades, qualificando-as como serviço público (PEREIRA, 2014, p. 247-248).

De acordo com Celso Antônio Bandeira de Mello:

\begin{abstract}
Serviço público é toda atividade de oferecimento de utilidade ou comodidade material destinada à satisfação da coletividade em geral, mas fruível singularmente pelo administrado, que o Estado assume como pertinente a seus deveres e presta por si mesmo ou por quem lhe faça as vezes, sob o regime de Direito Público - portanto, consagrador de prerrogativas de supremacia e de restrições especiais, instituído em favor dos interesses definidos como públicos no sistema normativo. (MELLO, 2013, p. 687)
\end{abstract}

Em sentido semelhante, Marçal Justen Filho assevera que

Serviço público é uma atividade pública administrativa de satisfação concreta de necessidades individuais ou transindividuais, materiais ou imateriais, vinculadas diretamente a um direito fundamental, insuscetíveis de satisfação adequada mediante os mecanismos da livre iniciativa privada, destinadas a pessoas indeterminadas, qualificadas legislativamente e executada sob regime de direito público. (JUSTEN FILHO, 2014, p. 727)

Fica evidente, ao menos a partir dos conceitos paradigmáticos apresentados, a importância do regime jurídico de direito público, que norteia o conceito de serviço público, a fim de garantir que os prestadores disponham dos meios para prestá-lo e a coletividade tenha a garantia de uma prestação de boa qualidade. Cuida-se o regime jurídico administrativo de elemento central para a noção de serviço público.

Também se observa dos conceitos transcritos que a noção de serviço público não pode ser compreendida isoladamente, havendo de ser analisado de forma sistêmica. Disso segue que somente poderá ser classificado como serviço público a prestação de comodidade material fruída de maneira individual pelo administrado e prestado de acordo com o referido regime jurídico-administrativo.

Do consagrado conceito de serviço público cunhado por Celso Antônio Bandeira de Mello, nota-se que a noção de serviço público é composta de dois elementos: i) o substrato material - que diz respeito à fruição singular pelo administrado da comodidade material imprescindível, oferecida pelo Estado de modo universal e geral, diretamente ou por quem lhe faça as vezes. Salvo exceções, essas atividades não podem ser prestadas por particulares, pois escapam à esfera da livre iniciativa e são estranhas à exploração de atividade econômica; e ii) o traço formal - que é a submissão ao regime de direito público. Somente o substrato material 
é insuficiente para qualificar o serviço como público, sendo necessário que seja prestada sob o regime de direito público, do contrário haverá serviço governamental, mas não serviço público.

A Constituição de 1988, elencou de maneira expressa alguns serviços públicos, como por exemplo o serviço de telecomunicação, de energia elétrica, fornecimento de água, entre outros. O rol exposto pelo texto constitucional não é exaustivo.

Ademais, a Carta Magna prevê as hipóteses de prestação exclusiva pelo Estado, ou quando poderá ser delegada ao particular. Bem como aquelas atividades que, quando prestadas pelo Estado serão serviço público, mas que também podem ser prestadas pelos particulares, mediante a fiscalização estatal.

Nesse sentido, existem quatro possibilidades: i) os serviços de prestação obrigatória e exclusiva do Estado - serviço posta e correio aéreo nacional; ii) serviços que o Estado tem obrigação de prestar e obrigação de conceder - radiodifusão sonora ou de sons e imagem; iii) serviço que o Estado tem obrigação de prestar, mas sem exclusividade - saúde, educação, previdência social, assistência social e radiodifusão sonora ou de sons e imagem; e por fim iv) serviços que o Estado não tem obrigação de prestar e não os prestando deverá promover concessão ou autorização - todos, previstos nos incisos XI e XII do art. 21 da Constituição de 1988 (MELLO, 2013, p. 704-706).

Ainda no âmbito do texto constitucional, mas especificamente em seu o art. 21, há menção de três modos diversos para tratar de outorga de prestação de serviço público a terceiros, a saber: concessão, permissão e autorização. Não obstante, quanto à autorização existe a aparente dubiedade, pois o art. 175 somente menciona os institutos da concessão e da permissão quando trata da incumbência de o Poder Público prestar serviço público ou da possibilidade de delegá-lo a particular. Todavia, a locução autorização foi utilizada para tratar do ato de poder de polícia que libera atividade privada, como por exemplo o serviço (não propriamente serviço público) de telecomunicação, ou ainda em casos em que é necessário resolver rapidamente a ausência de permissão ou concessão de serviço público.

O serviço público existe em razão do usuário e ele é a figura central, não o prestador. Prestador este que apesar de ser o titular do serviço público não necessariamente será o titular da prestação do serviço, haja vista que o Estado pode conceder, autorizar ou permitir que a prestação seja realizada por particular.

Desde que respeitados os limites constitucionais o legislador poderá reconhecer como serviço público determinada atividade estatal. Uma barreira importante para esta criação são as normas que garantem a ordem econômica, por meio da qual se garante a livre iniciativa. Muito embora o ordenamento autorize o Estado, em casos específicos (segurança nacional e relevante 
interesse coletivo), a exploração de atividades econômicas, essa atividade não será qualificada como serviço público.

Nesse ponto, convém tecer alguns comentários acerca do serviço público e da atividade econômica, sob a perspectiva consagrada por Eros Roberto Grau, segundo o qual "a prestação de serviço público está voltada à satisfação de necessidade, o que envolve a utilização de bens e serviços, recursos escassos. Daí podermos afirmar que o serviço público é um tipo de atividade econômica" (GRAU, 2015, p. 100).

Disso se segue que a atividade econômica em sentido amplo é gênero, do qual são espécies a atividade econômica em sentido estrito (campo natural de atuação da iniciativa privada) e o serviço público, cuja titularidade é atribuída ao Estado. (GRAU, 2015, p. 100).

Essa conclusão é reforçada quando se analisa o art. 175 da Constituição, inserido no Título VII "Da Ordem Econômica e Financeira", que expressamente determina que " Incumbe ao Poder Público, na forma da lei, diretamente ou sob regime de concessão ou permissão, sempre através de licitação, a prestação de serviços públicos."

Logo, visto que ao Estado é atribuido como campo natural de atividade a prestação de serviço público, enquanto espécie de atividade econômica em sentido amplo, nas hipóteses em que o Estado exercer atividade econômica em sentido estrito haverá intervenção (GRAU, 2015, p. 143).

Passada a análise do serviço público volta-se a atenção à obra pública, que pode ser conceituada como "construção, reparação, edificação de um bem imóvel pertencente ou incorporado ao domínio público" (MELLO, 2013, p. 711). Apesar de poder ser executada diretamente pelo Estado, é mais comum que haja contratação de terceiro para que realize a obra (execução indireta), hipótese que deverá ser instaurado processo licitatório, nos termos da Lei $\mathrm{n}^{\mathrm{o}} 8.666 / 93$.

A obra pública se diferencia do serviço público, pois a obra é estática e o serviço dinâmico, a obra é produto de ação humana e o serviço a própria ação; uma vez acabada a obra (em regra) essa prescinde de prestação de serviço público, já o serviço público é prestação.

A Lei no 8.666/93, no artigo $6^{\circ}$, I e II, define obra pública como toda "construção, reforma, fabricação, recuperação ou ampliação, realizada por execução direta ou indireta"; e serviço como "toda atividade destinada a obter determinada utilidade de interesse para a Administração, tais como: demolição, conserto, instalação, montagem, operação, conservação, reparação, adaptação, manutenção, transporte, locação de bens, publicidade, seguro, ou trabalhos técnicos profissionais". Não dá para entender a inclusão da locação de bens no conceito de locação de serviços. Enquanto a definição de obra pública é taxativa, abrangendo apenas a construção, a reforma e a ampliação, a de serviço é exemplificativa, o que permite concluir que toda atividade contratada pela Administração e que não se inclua no conceito de obra 
pública, é serviço. O contrato é de prestação ou locação de serviço. (DI PIETRO, 2017, p. 295)

Existem três modalidades de execução indireta de obra pública, previstas no art. $6^{\circ}$, VIII da Lei $n^{\circ}$ 8.666/93: a) empreitada global - a execução da obra é contratada integralmente por preço certo e total, podendo ser parcelado, sob responsabilidade do contratado (salvo desequilíbrio contratual oriundo de ato ou fato externos ao contratado); b) empreitada por preço unitário - em que o preço é ajustado por unidade de medida previamente escolhida e o pagamento realizado quando a Administração recebe a unidade; e c) empreitada integral modalidade na qual a totalidade do empreendimento é de responsabilidade do contratado, devendo entregar a obra em condições de operação.

A Lei Geral de Licitações prevê algumas especificidades para obras de grande vulto (em casos que o valor estimado ultrapasse 25 vezes o valor da concorrência para obras e serviços de engenharia) e para as obras de imenso vulto (valor estimando em 100 vezes o valor da concorrência para obras e serviços de engenharia).

Quanto a responsabilidade pela obra, tratando dos danos dela decorrentes, dos encargos trabalhistas, fiscais, comerciais e previdenciários. Ressalvado a responsabilidade pelos encargos previdenciários, que é solidária, os demais serão de responsabilidade do contratado.

Quanto aos danos causados a terceiros em razão de obra pública, há que se registrar que havendo culpa ou dolo do contratado será deste a responsabilidade, mas poderá emergir responsabilidade subsidiária do Estado em caso de insolvência do contratado. Será de responsabilidade do Estado, ainda, os danos causados a terceiros que não advierem de ação dolosa ou culposa do contratado.

\section{O questionamento da conformidade constitucional da lei das parcerias público- privadas}

Após a sanção da Lei 11.079/2004, alguns doutrinadores passaram a questionar e estudar sua constitucionalidade, sendo que, para alguns, já existe elementos suficientes para concluir pela sua inconstitucionalidade. A gênese da controvérsia está em um estudo empreendido pelo Conselho da seccional paulista da Ordem dos Advogados do Brasil, após provocação por parte de sua Comissão de Precatórios.

A fim de aprofundar a análise sobre o tema, a $\mathrm{OAB} / \mathrm{SP}$ submeteu a questão ao professor Kiyoshi Harada, que concluiu pela inconstitucionalidade de alguns dispositivos da 
Lei. A partir de então o debate ganhou corpo, possuindo contendores de ambos os lados da celeuma.

Como já foi mencionado, os principais dispositivos da Lei ${ }^{\circ} 11.079 / 2004$ reputados inconstitucionais são aqueles que dizem respeito às garantidas de pagamento do contrato instituídas em favor dos particulares.

Sem embargo, o sistema de garantias ao parceiro privado instituído pela Lei da PPP foi concebido para dar segurança ao parceiro privado de que a Administração Pública irá honrar com a contraprestação assumida. Se justificaria, dado os valores de grande monta envolvidos nos contratos e o largo prazo de sua vigência, no dizer de Fernando Vernalha Guimarães ( 2009, p. 15).

Importante ressalvar, antes de tratar de cada uma das garantias questionadas, que sua previsão no instrumento contratual não é obrigatória, ao revés, é facultativa: poderá - ou não ser instituída

\subsection{Lei ordinária ou lei complementar}

O primeiro questionamento sobre a constitucionalidade da Lei da PPP, envolve a espécie normativa que instituiu a parceria público-privada e, por conseguinte, definiu as garantias ao parceiro privado. A Lei n ${ }^{\circ}$ 11.049/2004 é lei ordinária e, por determinação do art. 163, III da Constituição da República a concessão de garantiras por entidades pública somente poderá ser instituída por lei complementar, o que acarretaria inconstitucionalidade formal da Lei $\mathrm{n}^{\circ} 11.049 / 2004$.

Todavia, as garantias de que trata a Lei da PPP é concedida por empresa estatal, que tem natureza jurídica de direito privado (c.f. art. 5, II e III do Decreto-lei no 200, de 25 de fevereiro de 1967). Nesse sentido:

\footnotetext{
A letra do inciso III do art. 163 da Constituição se refere, para a delimitação do campo temático que se reserva ao legislador complementar, à concessão de garantias por entidades públicas, o que deixa de fora as hipóteses de concessão de garantias por entidades administrativas de direito privado. É induvidoso que empresas públicas e demais entidades administrativas de direito privado - como o fundo garantidor - não possuem a natureza de entidade pública. São pessoas de direito privado, com natureza jurídica de direito privado, assim definidas pelo direito positivo. Logo, estão fora do âmbito temático reservado ao legislador complementar pela norma constitucional. (PEREIRA, 2013, p. 361)
}

Ou seja, ainda que prestada por integrante da Administração Pública indireta, visto possuir natureza de direito privado, não haveria a incidência do art. 163, III da CF, inexistindo para Cezar A. Guimarães Pereira inconstitucionalidade formal. 
Nesse campo, a possibilidade de vinculação de receitas da Administração Pública como garantia para pagamento da prestação pecuniária por ela contraída, que está prevista no art. $8^{\circ}$, I da Lei $11079 / 04^{3}$, é tida como incompatível com o texto constitucional e fruto de interpretação equivocada dada pelo legislador ordinário ao art. 167, IV da Constituição ${ }^{4}$.

Para os que defendem a não conformidade do art. $8^{\circ}$, I da Lei da PPP, a previsão constitucional veda a vinculação de receitas de impostos a órgãos, fundos ou despesas ressalvadas duas hipóteses. As exceções relativas as garantias dizem respeito ao que prevê o art. $165, \S 8^{\circ}$ (operações de crédito de antecipação de receita ${ }^{5}$ ) e ao disposto no art. $167, \S 4^{\circ}$ (pagamento de créditos da União ${ }^{6}$ ), ambos da Constituição da República.

Portanto, haveria dispositivo constitucional que expressamente proíbe a vinculação de receitas para pagamento da contrapartida pecuniária assumida pelo poder público, salvo nas exceções que estabelece, o que impediria a instituição de garantia desta natureza para pagamento de contrato administrativo em prol do parceiro privado.

Em outros termos, a receita pública não poderia ser dada em garantia a pagamento devido à particular, o que implica em inconstitucionalidade do dispositivo que possibilita que a Administração Pública vincule receita para pagamento da obrigação assumida.

A regra geral, que decorre do sistema constitucional, é a não vinculação das receitas públicas para garantia dessas ou daquelas obrigações contraídas pelo poder público. A exceção contida no inciso IV do art. 167 da CF não tem o sentido emprestado pelo legislador infraconstitucional que, por meio de uma interpretação literal e isolada, ignora em bloco os rígidos princípios de direito público. Aliás, o referido inciso, ao excepcionar a vinculação para um fimm específico, ipso fato, afastou a vinculação para fim outro. (HARADA, 2005).

\footnotetext{
${ }^{3}$ Art. 8o As obrigações pecuniárias contraídas pela Administração Pública em contrato de parceria público-privada poderão ser garantidas mediante:

I - vinculação de receitas, observado o disposto no inciso IV do art. 167 da Constituição Federal;

${ }^{4}$ Art. 167. São vedados: [...]

IV - a vinculação de receita de impostos a órgão, fundo ou despesa, ressalvadas a repartição do produto da arrecadação dos impostos a que se referem os arts. 158 e 159, a destinação de recursos para as ações e serviços públicos de saúde, para manutenção e desenvolvimento do ensino e para realização de atividades da administração tributária, como determinado, respectivamente, pelos arts. 198, § $2^{\circ}, 212$ e 37, XXII, e a prestação de garantias às operações de crédito por antecipação de receita, previstas no art. $165, \S 8^{\circ}$, bem como o disposto no $\S 4^{\circ}$ deste artigo.

${ }^{5}$ Art. 165. Leis de iniciativa do Poder Executivo estabelecerão: [...]

$\S 8^{\circ} \mathrm{A}$ lei orçamentária anual não conterá dispositivo estranho à previsão da receita e à fixação da despesa, não se incluindo na proibição a autorização para abertura de créditos suplementares e contratação de operações de crédito, ainda que por antecipação de receita, nos termos da lei.

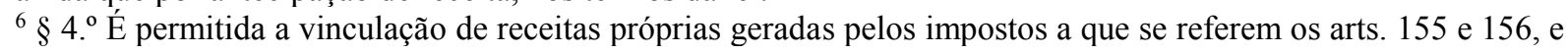
dos recursos de que tratam os arts. 157, 158 e 159, I, a e b, e II, para a prestação de garantia ou contragarantia à União e para pagamento de débitos para com esta
} 
Em oposição a este argumento, Oliveira (2015, p. 465) defende que a impossibilidade de vinculação de receitas diz respeito ao arrecadado com a cobrança de impostos, visto que a redação do art. 167, IV é literal em consignar esta espécie de tributo. De modo que não haveria qualquer óbice para que a vinculação seja realizada com receitas advinda de outras espécies de tributos.

Mais, o art. $8^{\circ}$, I da Lei da PPP expressamente consigna que a Administração Publica poderá garantir o pagamento da contraprestação pecuniária que assumiu por meio da vinculação de receita, observado o disposto no inciso IV do art. 167 da Constituição. É dizer, o legislador, ciente dos termos das vedações constitucionais, fez constar no diploma legislativo que regulamenta a PPP menção ao dispositivo que proíbe a vinculação de receitas de impostos.

A ausência de menção a impedimento de outras modalidades de receitas impede a interpretação indevidamente ampliada dessa norma com natureza claramente restritiva. Logo, as demais espécies de tributos, assim como os outros tipos de receitas públicas, não estão contempladas pela proibição do art. 167, IV, da CF: não havendo garantias incidente sobre imposto, a vinculação de receita prevista na Lei de PPP estará em plena conformidade com a ordem constitucional (OLIVEIRA, 2015, p. 465).

Portanto, haveria adequação da previsão de vinculação de receita como garantia da obrigação assumida pelo Poder Público, vedada que a receita vinculada advenha de impostos ${ }^{7}$, por determinação constitucional e da própria Lei $\mathrm{n}^{\circ}$ 11.079/2004.

Essa conclusão, no entanto, de cunho formal e positivista haverá de ser sopesada pelo STF na oportunidade que vier a enfrentar a questão, posto que o que está em jogo é a transferência do risco ordinário típico das concessões de serviço público do particular para o Estado. Em outros termos, o modelo instituído pela Lei da PPP transforma o Estado em seguradora do particular, numa distorção da ordem econômica capitalista adotada pela Constituição de 1988.

\subsection{O fundo garantidor de parceria público-privada}

\footnotetext{
7 "Sendo conclusivo, então, que a vedação prescrita pelo inciso IV do art. 167 não abarca receitas em geral, mas apenas os impostos, os fundamentos a amparar a tese negativista da vinculação de receitas teriam de ser buscados de outros dispositivos da Constituição, notadamente de princípios implícitos no seu texto. Mas o recurso a uma interpretação sistemática da Constituição, partindo-se da letra explicita do inciso IV do art. 167, impede essa conclusão hermenêutica. É que interpretação dessa ordem importaria em tornar inútil e supérflua a regra do inciso IV do art. 167, pelo menos naquilo que delimita a vedação à vinculação de receitas dos impostos. Ora, estivesse proscrita a vinculação de quaisquer receitas pelo texto constitucional, qual a função da primeira parte do inciso IV art. 167, que fixa a vedação específica à vinculação de impostos? Ou seja: é da própria disposição dessa regra que, a partir de uma leitura sistemática do texto constitucional, infere-se inexistir um princípio geral pela não vinculação de receitas públicas de toda ordem, implicitamente considerados. " (GUIMAR ̃̃ES, 2013, p. 369-370)
} 
O segundo problema específico da pesquisa, é a apontada inconstitucionalidade na previsão de instituição do Fundo Garantidor de Parcerias Público-Privado (FGP), cuja criação é autorizada pelo art. 16 da Lei da $\mathrm{PPP}^{8}$, uma vez que o fundo é constituído por bens públicos, que não são suscetíveis de penhora ou de outro meio de constrição para pagamento forçado.

A autorização para que a União possa participar de tal fundo foi autorizada por meio da Lei 13.529/2017, sendo que a sua administração será incumbida a instituição financeira controlada direta ou indiretamente pela União e funcionará sob o regime de cotas (c.f. art. $2^{\circ}$ da supracitada lei). A participação da União no fundo fica limitada a R \$ 180.000.000,00 (cento e oitenta milhões de reais) ${ }^{9}$.

Destaca Bandeira de Mello que a criação de meio privilegiado de pagamento de determinados credores viola o princípio da igualdade, previsto no art. $5^{\circ}$ da $\mathrm{CF}$ e os princípios da impessoalidade e da moralidade, insculpidos no art. 37 da Magna Carta. Além disso, a regra estabelecida pelo constituinte para pagamentos das dívidas do Poder Público é aquela prevista do art. 100 da Constituição ${ }^{10}$, que estabelece o regime de precatório para o pagamento das dívidas do Estado (MELLO, 2013, p. 810).

Para os que defendem a constitucionalidade da instituição do fundo (FGP), argumentase que não há violação do art. 100 da CF, pois para fazer frente a suas dívidas a Administração Pública poderia, por exemplo, desafetar um bem público e dá-lo em garantia e que a criação de entidade de direito privada para funcionar como fundo garantidor encontra respaldo constitucional no art. $173, \S 1^{\circ}$, III $^{11}$, dispositivo que prevê que as estatais que exercem atividade

\footnotetext{
${ }^{8}$ Art. 16. Ficam a União, seus fundos especiais, suas autarquias, suas fundações públicas e suas empresas estatais dependentes autorizadas a participar, no limite global de R \$6.000.000.000,00 (seis bilhões de reais), em Fundo Garantidor de Parcerias Público-Privadas - FGP que terá por finalidade prestar garantia de pagamento de obrigações pecuniárias assumidas pelos parceiros públicos federais, distritais, estaduais ou municipais em virtude das parcerias de que trata esta Lei. (Redação dada pela Lei nº 12.766 , de 2012)

${ }^{9}$ Art. $1^{\circ}$ Fica a União autorizada a participar de fundo que tenha por finalidade exclusiva financiar serviços técnicos profissionais especializados, com vistas a apoiar a estruturação e o desenvolvimento de projetos de concessão e parcerias público-privadas da União, dos Estados, do Distrito Federal e dos Municípios, em regime isolado ou consorciado, até o limite de R $\$ 180.000 .000,00$ (cento e oitenta milhões de reais).

${ }^{10}$ Art. 100. Os pagamentos devidos pelas Fazendas Públicas Federal, Estaduais, Distrital e Municipais, em virtude de sentença judiciária, far-se-ão exclusivamente na ordem cronológica de apresentação dos precatórios e à conta dos créditos respectivos, proibida a designação de casos ou de pessoas nas dotações orçamentárias e nos créditos adicionais abertos para este fim.

${ }^{11}$ Art. 173. Ressalvados os casos previstos nesta Constituição, a exploração direta de atividade econômica pelo Estado só será permitida quando necessária aos imperativos da segurança nacional ou a relevante interesse coletivo, conforme definidos em lei.

$\S 1^{\circ} \mathrm{A}$ lei estabelecerá o estatuto jurídico da empresa pública, da sociedade de economia mista e de suas subsidiárias que explorem atividade econômica de produção ou comercialização de bens ou de prestação de serviços, dispondo sobre: [...]

III - licitação e contratação de obras, serviços, compras e alienações, observados os princípios da administração pública;
} 
de fomento estarão sujeitas ao regime jurídico próprio das empresas privadas (BINENBOJM, 2005, p. 172).

No já citado parecer solicitado pela $\mathrm{OAB} / \mathrm{SP}$, Kioshi Harada indica, além da restrição apontada por Bandeira de Mello, outras normas constitucionais que seriam infringidas pela previsão de instituição do FGP, a saber, o art. 165, $\S 9^{\circ}$, II da CF, o art. 36 do ADCT, e o art. 167, II, IV e VII, visto que contrário aos princípios que norteiam o orçamento da Administração Pública, além de, por afastar do controle do Poder Legislativo (por meio dos Tribunais de Contras) os gastos de dinheiro público, o que violaria o que prevê os arts. 70 e 71 da Constituição. (HARADA, 2005)

O Governo Federal não se impressionou com o problema objeto dessa pesquisa.

No ano de 2012, foi sancionada a Lei $\mathrm{n}^{\mathrm{0}}$ 12.712, de 30 de agosto, conversão da Medida Provisória $\mathrm{n}^{\mathrm{o}} 564$, de 3 de abril de 2012, que promoveu uma série de alterações legislativas e autorizou, em seu art. 37 o Poder Executivo a criar empresa pública (mas que pode ser convertida em sociedade de economia mista, c.f. art. $\left.41, \S 2^{\circ}, I\right)$, vinculada ao Ministério da Fazenda, sob a forma de sociedade anônima, denominada Agência Brasileira Gestora de Fundos Garantidores e Garantias S.A. (ABGF). O objeto da Agência está delimitado nas disposições do art. 38.

Foi por meio do Decreto $n^{\circ} 7.976$, de $1^{\circ}$ de abril de 2013 que a União criou a AGBF com capital inicial de $\mathrm{R} \$$ 50.000.000,00 (cinquenta milhões de reais). Em assembleia geral extraordinária a Agência criou o Fundo Garantidor de Infraestrutura - FIG, que tem por finalidade garantir os projetos de parcerias público-privadas ${ }^{12}$ da União, dos Estados e do Distrito Federal.

No que se refere a lei que autoriza a criação da estatal é cediço que esta autorização deve ser feita por lei específica, que mencionará o nome da entidade que pretende criar e exporá o objetivo a ser cumprido pelo novo ente. Para os casos de empresas estatais exploradoras de atividade econômica existe demanda por lei que defina os casos de relevante interesse coletivo

\footnotetext{
${ }^{12}$ Do Estatuto do Fundo Garantidor de Infraestrutura extrai-se as seguintes disposições:

Art. $1^{\circ} \mathrm{O}$ Fundo Garantidor de Infraestrutura - FGIE, constituído pela Agência Brasileira Gestora de Fundos Garantidores e Garantias S.A. - ABGF, regido pelo presente Estatuto e pelas demais disposições legais e regulamentares que lhe forem aplicáveis, terá prazo de duração indeterminado.

$\S 1^{\circ} \mathrm{O}$ FGIE, de natureza privada, tem patrimônio próprio separado do patrimônio dos cotistas e da Administradora, estará sujeito a direitos e obrigações próprias, não contará com qualquer tipo de garantia ou aval por parte do poder público e responderá por suas obrigações até o limite dos bens e direitos integrantes do seu patrimônio.

$\S 2^{\circ} \mathrm{O}$ FGIE tem por finalidade garantir, direta ou indiretamente, cobertura para risco de crédito, risco de performance, risco de descumprimento de obrigações contratuais ou risco de engenharia, nas operações relacionadas: [...]

IV - a projetos resultantes de parcerias público-privadas na forma da Lei no 11.079 , de 30 de dezembro de 2004, inclusive os organizados por Estados ou pelo Distrito Federal;
} 
e os imperativos de segurança nacional, pois são somente nestas hipóteses que o Estado está autorizado a exercer atividade econômica. Fato que não se observa na lei que autorizou a criação da Agência Brasileira Gestora de Fundos Garantidores e Garantias S.A.

Com efeito, fortes são os argumentos apresentados pela doutrina que aponta pela inconstitucionalidade do Fundo Garantidor de Parcerias Público-Privadas. Novamente, subverte-se a Constituição de 1988 para a alegria do parceiro privado, que pode transferir para o Estado os encargos que haveria de suportar, confirmando-se o velho conhecido capitalismo do século XXI, cujos lucros são privados e os riscos inerentes à exploração de atividade econômica, que também caracteriza a prestação de serviços públicos por particulares, são transferidos para o combalido Estado brasileiro, financiado pela debilitada sociedade brasileira.

O tema, certamente, merece contestação via controle concentrado de constitucionalidade.

\subsection{Solução privada de conflitos}

O terceiro problema está relacionado à adoção de formulas privadas de solução de conflitos no âmbito das PPP's. Com efeito, a Lei da PPP prevê a possibilidade de adoção de mecanismos privados para dirimir conflitos decorrentes do contrato de parceria (art. 11, III). ${ }^{13}$ Sob o argumento de que o serviço público envolve interesses de toda a sociedade e de que não está sujeito às regras de comércio, o modelo é alvo de alegação de inconstitucionalidade.

Contra essa posição, afirma-se que o novo Código de Processo Civil também apresenta dispositivos que possibilitam a Administração Pública se submeter a meios alternativos de resolução de conflitos, o que demonstra a legitimidade de tal prática. Ademais, para Gustavo Binenbojm:

Do ponto de vista estritamente patrimonial, a arbitragem poderá ser, em muitos casos, a mais vantajosa para a Administração do que a solução judicial. Imagine-se, por exemplo, um contrato rescindido por culpa do parceiro privado, em que haja uma verba indenizatória devida à Administração. A maior celeridade do procedimento arbitral virá em favor do Poder Público. Em uma palavra: nada garante que a solução judicial seja a mais favorável ao patrimônio público. De outra parte, seria imoral - e, portanto, inconstitucional - imaginar que a Administração Pública - devedora contumaz - possa preferir a solução judicial à arbitral por ser a primeira a mais morosa . (BINENBOJM, 2005, p. 174).

\footnotetext{
${ }^{13}$ Art. 11. O instrumento convocatório conterá minuta do contrato, indicará expressamente a submissão da licitação às normas desta Lei e observará, no que couber, os $\S \S 3^{\circ} \mathrm{e} 4^{\circ}$ do art. 15, os arts. $18,19 \mathrm{e} 21$ da Lei n ${ }^{\circ} 8.987$, de 13 de fevereiro de 1995, podendo ainda prever: [...]

III - o emprego dos mecanismos privados de resolução de disputas, inclusive a arbitragem, a ser realizada no Brasil e em língua portuguesa, nos termos da Lei n ${ }^{\circ}$ 9.307, de 23 de setembro de 1996, para dirimir conflitos decorrentes ou relacionados ao contrato.
} 
A rigor, o fato de se adotar a arbitragem como mecanismo para a solução de conflitos decorrentes de contratos de PPP's, por si só não representa perigo de maior monta, inclusive porque a lei ordinário não pode simplesmente revogar o princípio da inafastabilidade da jurisdição, previsto no art. 5 XXXV da Constituição de 1988.

\section{Conclusões}

Como afirmado inicialmente, a presente pesquisa pretendeu, após análise concisa do instituto da parceria público-privada e de breves comentários sobre os conceitos de serviço público e de obra pública, apresentar os principais argumentos da controvérsia relativa à conformidade constitucional da Lei da PPP. A fim de contribuir com o debate a respeito do tema central, desdobrou-se a questão em três problemas específicos de pesquisa: (1) A Lei 11.049/2004 - lei ordinária - poderia estabelecer garantias ao parceiro privado pela Administração Pública, sem ferir o disposto no art. 163, inc. III, da CF? (2) O Fundo Garantidor de Parcerias Público Privadas é compatível com o art. 100 da Constituição de 1988 e com os princípios constitucionais da igualdade, da impessoalidade e da moralidade? (3) É possível a adoção de mecanismos privados (arbitragem) para dirimir conflitos decorrentes do contrato de parceria, em especial quando o litígio envolver a Administração Pública?

No tocante aos debates sobre a (in)constitucionalidade da Lei de Parceria PúblicoPrivada foram apresentados os principais argumentos, de ambos os lados, discorrendo-se a respeito de cada um deles, a fim de construir um panorama geral sobre o embate, limitado, naturalmente, aos questionamentos específicos, de modo a servir de estudo inicial para pesquisas que se empreenderão futuramente.

Notou-se pelos resultados da pesquisa bibliográfica, que para quase todos os argumentos pela inconstitucionalidade da Lei $n^{\circ} 11.049 / 2004$ existem outros que os refutam com eficiência. No entanto, se o terceiro questionamento não parece ferir a Constituição, os problemas relativos à fixação de garantias por lei ordinária e a criação do Fundo Garantidor de Parcerias Público-Privadas parecem não se harmonizar com a Constituição de 1988, debate que se espera seja continuado na academia e levado, via controle concentrado, à discussão junto ao Supremo Tribunal Federal.

O desenvolvimento da infraestrutura e a prestação de serviços públicos são essenciais para o desenvolvimento econômico e social do Brasil. O modelo de PPP é um instrumento de que pode dispor o Poder Público para fomentar o incremento e o aperfeiçoamento dessas 
atividades, sempre, no entanto, respeitada a Constituição de 1988, posto ser o cidadão o ator ato principal de um Estado Social e Democrático de Direito, que não pode e não deve ser pervertido por regras infraconstitucionais a serviço exclusivamente de interesses econômicos privados, típicos da era em que vivemos.

\section{Referências bibliográficas}

BINENBOJM, Gustavo. As Parcerias Público-Privadas (PPPS) e a Constituição. In. Revista de Direito Administrativo. Rio de Janeiro, n. 241: p. 159-175, jul./set. 2005.

DI PIETRO, Maria Sylvia. Direito Administrativo. 30ª ed. Rio de Janeiro: Forense, 2017.

GRAU, Eros Roberto. A Ordem Econômica na Constituição de 1988. 17 ed. São Paulo: Malheiros, 2015.

GUIMARÃES, Fernando Vernalha. A constitucionalidade do sistema de garantias ao parceiro privado previsto pela lei geral de parceria público-privada - em especial, da hipótese dos fundos garantidores. In. Revista Jurídica (UNICURITIBA). Curitiba, n. 23, Temática n. 7: p. 11-56, 2009-2.

GUIMARÃES, Fernando Vernalha. Parceria público-privada. 2a ed. São Paulo: Saraiva, 2013.

HARADA, Kiyoshi. Inconstitucionalidade do Fundo Garantidor das Parcerias PúblicoPrivadas. Art. $8^{\circ}$ da Lei $n^{\circ}$ 11.079/04 (Parecer). Revista Consultor Jurídico, 21 de janeiro de 2005. Disponível em <http://www.conjur.com.br/2005-jan-21/oabsp_lei_ppps_pontos_inconstitucionais>. Acesso em 24 de agosto de 2017.

JUSTEN FILHO, Marçal. Curso de Direito Administrativo. 10 a ed. São Paulo: Revista dos Tribunais, 2014.

JUSTEN FILHO, Marçal. Teoria Geral das Concessões de Serviço Público. São Paulo: Dialética, 2003. 
MEDAUAR, Odete. Direito Administrativo Moderno. 12 ed. São Paulo: Revista dos Tribunais, 2008.

MELLO, Celso Antônio Bandeira de. Curso de Direito Administrativo. 30ª ed. São Paulo: Malheiros, 2013.

MUKAI, Toshio. Concessões, permissões e privatizações de serviços públicos: comentários à Lei n. 8.987, de 13 de fevereiro de 1995. $5^{\text {a }}$ ed. São Paulo: Saraiva, 2007.

NOHARA, Irene Patrícia. Desafios jurídicos das Parcerias Público-Privadas (PPPs) e desenvolvimento nacional sustentável. In. Revista de Direito Econômico e Socioambiental, Curitiba, v. 5, n. 2, p. 184-203, jul./dez. 2014.

OLIVEIRA, Fernão Justen de. Garantias ao Parceiro Privado e Comprometimento Fiscal. In. JUSTEN FILHO, Marçal; SCHWIND, Rafael Wallbach (coords). Parcerias PúblicoPrivadas: Reflexões sobre os 10 anos da Lei 11.079/2004. São Paulo: Revista dos Tribunais, 2015. p. 459-473.

PEREIRA, Cesar A. Guimarães. Serviço Público na ordem econômica da Constituição de 1988. In: CLÈVE, Clèmerson Merlin (coord.). Direito Constitucional Brasileiro, v. 3: Constituições Econômica e Social. São Paulo: Revista dos Tribunais, 2014. p. 244-266.

RECK, Melina Breckenfeld. Constituição, regulação e desenvolvimento econômico. In: CLÈVE, Clèmerson Merlin (coord.). Direito Constitucional Brasileiro, v. 3: Constituições Econômica e Social. São Paulo: Revista dos Tribunais, 2014. p. 267-286. 


\title{
ELEMENTOS PARA A PRÁTICA DE ADVOCACIA PREVENTIVA NO ÂMBITO DA ADVOCACIA-GERAL DA UNIÃO
}

\author{
Juliano Scherner Rossi \\ Advocacia-Geral da União \\ Viviane Regina da Silva \\ Advocacia-Geral da União
}

\section{Resumo}

Este artigo examina elementos teóricos para construção de métodos e abordagens práticas para a advocacia preventiva no âmbito da Advocacia-Geral da União. Advocacia preventiva é prática que visa aos indivíduos a regularem suas atividades para evitar problemas jurídicos, em contraste com o aspecto litigioso do Direito, que se manifesta somente após o surgimento de uma lide. $\mathrm{O}$ estudo indicou que a ênfase atual da advocacia preventiva na AGU ainda está focada na solução alternativa de controvérsias (mediação, negociação, arbitragem, conciliação, ajustamento de condutas), e não na conformidade dos atos estatais à lei. A pesquisa é exploratória com revisão bibliográfica. São apresentadas duas seções, a primeira com fundamentos teóricos de advocacia preventiva; a segunda com levantamento das iniciativas atuais de advocacia preventiva na Advocacia-Geral da União.

Palavras-Chave: Advocacia preventiva, Advocacia-Geral da União, Prevenção de litígios, Solução alternativa de controvérsias.

\section{Abstract/Resumen/Résumé}

This research examines theoretical approaches for the construction of methods in preventive law for governmental bodies. Preventive Law is a legal practice that seeks to help individuals to regulate their activities to avoid legal problems, in contrast to the litigious aspect of Law, which manifests itself only after the emergence of a controversy. The study indicated that the current emphasis of preventive law in the Union Attorney General's Office (Advocacia-Geral da União) bodies is still focused on alternative dispute resolution (mediation, negotiation, arbitration, conciliation, conduct adjustment) rather than on compliance with the law. The research is exploratory with bibliographic review. Two sections are presented, the first with 
theoretical grounds of preventive advocacy; the second with a survey of current preventive advocacy initiatives in the Union Attorney General's Office.

Keywords/Palabras-claves/Mots-clés: Preventive law, Union Attorney General's Office (Brazil), Litigation prevention. Alternative dispute resolution.

\section{Introdução}

A advocacia preventiva tem grande relevância para Advocacia-Geral da União (AGU), mas é pouco desenvolvida metodologicamente. Isso faz com que o conceito não seja explorado satisfatoriamente. As vertentes atuais na AGU privilegiam soluções alternativas de controvérsias, não a eliminação e neutralização das possíveis fontes de controvérsias ou o aumento da conformidade à lei. Propõe-se aqui a criação de métodos e abordagens que privilegiem esse tipo de prevenção.

Advocacia preventiva não é propriamente uma teoria, mas uma abordagem prática. Para efeitos da análise proposta neste artigo, a advocacia preventiva será estudada a partir de três vertentes teóricas, uma escola americana, uma escola europeia e uma escola canadense. A temática de advocacia preventiva desenvolveu-se metodologicamente na segunda metade do século XX, nos EUA, e atualmente majoritariamente nos EUA e na Europa (ABREU, 2017).

Para efeito deste artigo, advocacia preventiva será compreendida como a "prática jurídica que procura ajudar os indivíduos a regularem suas atividades para evitar problemas jurídicos, em contraste com o aspecto litigioso do Direito, que se manifesta somente após o surgimento de uma lide (BROWN, 1971; p. 1181; tradução nossa).

Há no Brasil uma lacuna concernente ao estudo da advocacia preventiva. Por ser um tema abordado de forma ainda muito incipiente nas faculdades de Direito nacionais, são escassas as pesquisas científicas e publicações acerca dessa temática no cenário brasileiro.

Este estudo visa especialmente a revisão bibliográfica e é pesquisa exploratória. $O$ objetivo não é propriamente a análise, mas o levantamento de alternativas para uma advocacia preventiva no âmbito da AGU. Será feito também um levantamento das iniciativas na AGU acerca da prevenção de litígios. A finalidade é a de levantamento da situação atual, para indicação de diagnóstico, mais do que análise do modelo adotado.

Revisão sistemática de literatura (FERENHOF; FERNANDES, 2015) indicou a ausência de tratamento do tema na bibliografia nacional. A busca pelo termo "advocacia preventiva" nas bases de dados do Portal de Periódicos da Coordenação de Aperfeiçoamento 
de Pessoal de Nível Superior (CAPES), Catálogo de Teses e Dissertações da CAPES, Journal Storage (JSTOR) e Scientific Eletronic Library Online (SciELO) e Scientific Periodicals Eletronic Library (SPELL) devolveu nenhum resultado.

O estudo se inicia apresentando uma fundamentação teórica baseada no levantamento bibliográfico já existente na literatura. Na seção seguinte são apresentados os achados no âmbito da Advocacia-Geral da União.

\section{Fundamentos da advocacia preventiva}

A crescente judicialização no Brasil tem como principal protagonista o setor público federal, que se caracteriza como o maior litigante nacional, apresentando um percentual de $38,5 \%$ das questões de litigância do país, seguido do setor público estadual com $7,8 \%$ e o municipal com 5,2\%, de modo que os entes da Administração Pública perfazem um total aproximado de 51,5\% dos casos de litigância no Brasil (BRASIL, 2012). Além da quantidade, existe uma perfil de repetição entre os processos em que é parte a administração pública. Dados do Conselho Nacional de Justiça (CNJ) indicam aproximadamente um milhão de processos nas quais a Administração Pública Federal é parte sobrestados em incidentes de demandas repetitivas (BRASIL, 2018e).

A problemática do excesso de litigância judicial envolvendo o Poder Público apresenta consequências práticas perniciosas para a advocacia pública. Em resposta à crescente demanda, as Procuradorias necessitam contratar mais procuradores, servidores técnicos, estagiários e terceirizados, bem como ampliar de suas instalações físicas, bens móveis, frotas de carros, equipamentos tecnológicos, etc., com aumento dos custos e despesas de recursos públicos. Caso o quadro de recursos humanos não seja ampliado, o excesso de litígios envolvendo o Poder Público acarretará diminuição da capacidade de defesa do estado em juízo e sobrecarga de atividades para os servidores técnicos e procuradores associada a um contrapeso de tarefas cognitivas que irão repercutir sobre a saúde e a qualidade de vida dos funcionários da advocacia pública (SILVA, 2016).

Com a prevenção de controvérsias e litígios obtém-se economia de tempo e recursos que podem ser utilizados para a promoção do trabalho produtivo na esfera do Poder Público. A adoção de ferramentas de advocacia preventiva possibilita que problemas desnecessários sejam evitados em sua origem, de modo que o custo de prevenção de problemas passa a ser menor que o custo para resolução dos mesmos (BROWN, 1950). 
Além de redução de litigiosidade, a advocacia preventiva é um instrumento capaz de diminuir os riscos jurídicos. Esses dizem respeito não apenas ao litígio, mas, hoje de modo crescente, a conformidade do estado à lei.

Como efeitos ainda adicionais, a advocacia seria capaz de contribuir reflexamente com a redução da ineficiência técnica e econômico-financeira da Administração Pública, minorando assim o congestionamento processual do Judiciário. Com isso, promove o acesso a serviços jurisdicionais de qualidade prestados pelo Estado.

A temática de advocacia preventiva desenvolveu-se metodologicamente na segunda metade do século XX, nos EUA, e no presente momento majoritariamente nos EUA e na Europa (ABREU, 2017). Advocacia preventiva não é propriamente uma teoria, mas uma abordagem prática, desenvolvida de modo empírico pelos escritórios de advocacia.

$\mathrm{Na}$ doutrina, é proveniente do campo de estudos do Direito Preventivo, originariamente preconizado no início da década de 50 pelo advogado norte-americano e professor de Direito Louis M. Brown. Em um esforço para ajudar as pessoas a minimizar o risco de problemas legais e maximizar seus benefícios, Brown (1950) fundou o National Center for Preventive Law na Universidade de Denver e publicou a obra intitulada Preventive Law em 1950, seguida de uma vasta produção bibliográfica sobre o assunto. A abordagem deveu-se a uma analogia com a medicina preventiva: um ramo da ciência médica para desenvolver métodos de prevenir a ocorrência de doenças (como a vacinação) (ALBUQUERQUE, 2016). As técnicas de direito preventivo para indivíduos incluem serviços como o check-up jurídico individual. Para clientes corporativos, abrange todas as formas de compliance e auditoria jurídica. As técnicas mais recentes são o controle periódico e a auditoria jurídica. (MOREIRA, ALMEIDA, GARCIA; 2016).

Outra vertente está associada à escola finlandesa do Direito Proativo, que tem como principal expoente Helena Haapio (2010), da University of Vaasa (Finlândia) e na Nordic School of Proactive Law. De acordo com Haapio (2010, p. 10), o Direito Proativo nasceu a partir das necessidades das grandes empresas em aplicar os princípios da administração da qualidade e do gerenciamento de riscos para aperfeiçoar seus processos de contratação em transações internacionais. Percebe-se que o foco não estava nas questões legais, mas sim, na qualidade dos negócios empreendidos. Logo, o Direito Proativo possui uma perspectiva holística e privilegia a formação de equipes multidisciplinares para tratar questões jurídicas, pois, para além de juristas, são necessários profissionais com conhecimentos em administração de projetos, gestão de riscos, gestão da qualidade, tecnologia, contratos, etc. 
Sob essa perspectiva, os sistemas jurídicos devem priorizar o gerenciamento dos riscos legais de modo a criar uma cultura de conduta ética capaz de incentivar os funcionários a tomarem decisões mais bem informadas, haja vista a crescente preocupação com a reputação organizacional e a pressão por adaptação à governança e ao compliance (conformidade) corporativo. Sob esse prisma, a advocacia preventiva consiste na busca proativa da atuação preventiva conjunta entre advogados e clientes, objetivando o atendimento de todas as exigências legais por parte da empresa e seus respectivos negócios (HAAPIO, 2010). Sob a égide do Direito Proativo, o objetivo da advocacia preventiva é "construir um sistema de proteção ou um mecanismo de defesa que faz com que o cliente corporativo, sua gerência e pessoal, fortes e resistente; os mantém em boa saúde legal e 'imune' aos riscos legais inerente aos negócios" (HAAPIO, 2010, p. 25)

Tanto o Direito Preventivo quanto o Direito Proativo são orientados para o futuro e priorizam a eliminação das causas dos problemas em detrimento de uma postura reativa ou corretiva. Em ambas as perspectivas, o advogado assume o papel de planejador, designer e solucionador de problemas, ao invés de um beligerante combatente/lutador. Contudo, existem algumas diferenças importantes entre a advocacia preventiva sob a ótica do Direito Preventivo e do Direito Proativo. O primeiro enfatiza o papel do advogado na promoção da "saúde jurídica", na prevenção de problemas e gestão de riscos jurídicos, de maneira que os clientes assumem uma posição passiva e apenas recebem as informações. Já o segundo, destaca o papel do cliente e a importância da colaboração cliente-advogado, a partir da seguinte perspectiva:

Para usar o analogia médica, a ideia não é apenas prevenir problemas de saúde, mas promover o bem-estar. O objetivo é incorporar conhecimento e habilidades jurídicas na estratégia e ações cotidianas para promover ativamente o sucesso do negócio, garantir os resultados desejados, e equilibrar o risco com recompensa. (HAAPIO, 2010).

Percebe-se que a advocacia preventiva consoante ao Direito Proativo está alinhada ao conceito de Gestão do Conhecimento, que pode ser entendido como "a estratégia que transforma bens intelectuais da organização - informações registradas e o talento dos seus membros - em maior produtividade, novos valores e aumento de competitividade" (MURRAY apud CARVALHO; SANTOS, 1999, p. 2). Com base nesse entendimento, o papel do advogado proativo é compreender o que o cliente deseja alcançar e os riscos que está disposto a assumir, de modo que possa ajudá-lo a estruturar negócios e preparar contratos capazes de refletir os objetivos do cliente. $\mathrm{O}$ advogado proativo deverá trabalhar para minimizar os riscos a partir de uma visão de gestão de negócios associada com advocacia preventiva, incentivando o aumento 
da conscientização dos direitos e responsabilidades legais por parte dos membros de uma organização a fim de encorajar a prevenção e a rápida resolução de conflitos na instituição.

Happio (2010, p. 25) destaca que, sob a égide do Direito Preventivo, a advocacia preventiva enfatiza os seguintes preceitos: a) atendimento jurídico profissional; b) gerenciamento de conflitos; c) a prevenção de litígios; d) o gerenciamento de riscos e, e) a minimização dos custos e perdas. Com amparo no Direito Proativo, a advocacia preventiva encontra subsídios nos preceitos supracitados, contudo, amplia seu leque de atuação com destaque aos seguintes pontos: a) alcance dos resultados desejados; b) eliminação das causas de problemas; c) cuidado compartilhado e abordagem de equipe, d) advogados apoiando o autocuidado dos clientes; e) estímulo ao autocuidado dos clientes, não apenas no campo jurídico, mas também nos demais aspectos do negócio do cliente.

A expansão da práxis da advocacia preventiva sob a perspectiva do Direito Proativo é um desafio. A aplicação sistemática dessa abordagem não é ensinada em nenhum lugar e a maioria dos clientes desenvolveram uma percepção de um estereótipo beligerante, agressivo e combativo em relação aos advogados (HAAPIO, 2010).

A escola canadense de Direito Preventivo tem seu marco teórico pautado na obra intitulada Droit Préventif: Le Droit Au-Delà de la Loi, publicada por Pierre Noreau em 1993. Titular do Centro de Pesquisa em Direito Público da Universidade de Montreal, Noreau (1993) entende que o Direito Preventivo está associado às Alternative Dispute Resolution (Resoluções Alternativas de Disputas), que representam os "Meios Adequados de Tratamento de Conflitos". Nessa perspectiva, o Direito Preventivo se caracteriza como um campo de pesquisa, análise e prática baseado em uma compreensão ampliada do Direito, que nessa perspectiva, é entendido como um processo de prevenção de disputas e conflitos e está associado às práticas de negociação, mediação, arbitragem e conciliação (NOREAU, 1993). Sob o paradigma da escola canadense e da atuação por solução alternativa, o Direito Preventivo opera perante um conflito normalmente já preexistente, assim como na atuação judicial. Desse modo, as Resoluções Alternativas de Disputas (RADs) são tão somente instrumentos autocompositivos, capazes de possibilitar às partes o tratamento desses conflitos com maior autonomia, viabilizando o distanciamento das vias contenciosas conforme as peculiaridades de cada caso.

Os construtos mais relevantes sobre advocacia preventiva são identificados na literatura internacional e no Brasil ainda são escassos os profissionais e instituições do campo jurídico que atendam demandas organizacionais a partir do viés preventivo. Comumente os advogados são chamados apenas nos momentos de crise e os problemas, na maioria dos casos, são resolvidos pela via judicial. 
O Estatuto da Advocacia e a Ordem dos Advogados do Brasil (BRASIL, 1994) prevê no âmbito dos limites privativos da advocacia, o exercício das atividades de consultoria, assessoria e direção jurídicas (artigo $1^{\circ}$, II), as quais subsidiam o exercício da advocacia preventiva quando desenvolvidas antes do conflito. Nessa perspectiva, o advogado deve evitar o litígio posicionando-se ao lado de seu cliente, sanando as dúvidas de menor complexidade e elaborando pareceres capazes de oferecer segurança jurídica para a tomada de decisões a partir de uma análise dos riscos jurídicos envolvidos. Já o Código de Ética e Disciplina da Ordem dos Advogados do Brasil (OAB, 2015), prescreve no parágrafo único do artigo $2^{\circ}$ que são deveres do advogado "[...] VI - estimular, a qualquer tempo, a conciliação e a mediação entre os litigantes, prevenindo, sempre que possível, a instauração de litígios; VII - desaconselhar lides temerárias, a partir de um juízo preliminar de viabilidade jurídica”. Sob esse aspecto, pode-se inferir que a atividade de advocacia preventiva está contemplada de forma implícita tanto no Estatuto da Advocacia quanto no Código de Ética da OAB, ao passo que essas normativas jurídicas estimulam a busca pela solução de conflitos antes do litígio judicial.

\section{A advocacia preventiva no âmbito da Advocacia Geral da União (AGU)}

À luz do artigo 131 da Constituição Federal de 1988 e da e da Lei Complementar ${ }^{\circ}$ 73/1993, atribui-se à Advocacia-Geral da União (AGU) as competências constitucionais de representação judicial e extrajudicial da União, em consonância com o exercício das atividades de consultoria e assessoramento jurídico do Poder Executivo (BRASIL, 1988; BRASIL, 1993).

A prevenção de litígios, na Lei Orgânica da AGU está prevista em apenas uma passagem, no Art. $4^{\circ}$, XI, da LC n. 73/93, com ênfase na solução alternativa de controvérsias:

Art. $4^{\circ}$ - São atribuições do Advogado-Geral da União:

XI - unificar a jurisprudência administrativa, garantir a correta aplicação das leis, prevenir e dirimir as controvérsias entre os órgãos jurídicos da Administração Federal;

A Lei $n^{\circ} 13.140$, de 26 de junho de 2015, que dispõe sobre a autocomposição de conflitos no âmbito da administração pública, seguiu linha semelhante. Ela prevê a criação de câmaras de prevenção e resolução administrativa de conflitos no âmbito dos respectivos órgãos da Advocacia Pública para dirimir conflitos entre órgãos e entidades da administração pública, avaliar a admissibilidade dos pedidos de resolução de conflitos, por meio de composição, no 
caso de controvérsia entre particular e pessoa jurídica de direito público e promover, quando couber, a celebração de termo de ajustamento de conduta (BRASIL, 2015c).

O exercício da advocacia preventiva na perspectiva da AGU se dá por intermédio da prestação de consultoria e assessoramento jurídico na esfera do Poder Executivo Federal. Na esfera do Poder Público, destaca-se a definição de advocacia preventiva postulado pela Advocacia-Geral da União por intermédio da Procuradoria Federal junto à Universidade Federal de Santa Catarina (PFUFSC) no âmbito da Portaria $n^{\circ}$ 1/2017/PFUFSC/GR, de 13 de abril de 2017 (BRASIL, 2017c). Conceitualmente, as ações de advocacia preventiva são aquelas que visam a "prevenção de litígios ou redução dos seus efeitos, a redução de risco jurídico e, em geral, a melhor adequação de processos e atos dos agentes públicos à lei [...] constituir-seão de análise da questão jurídica, a qual identificará, quantificará e tratará dos riscos, formulação de recomendações e acompanhamento das suas implementações" (BRASIL, 2017c).

A segurança jurídica é uma condição básica para o exercício das atividades da Administração Pública. Nessa seara, o assessoramento jurídico é a atividade focada na prevenção dos riscos e auferição de benefícios legais, contemplando as orientações sobre dúvidas de menor complexidade, fases iniciais de discussão interna sobre atos administrativos, participação em reuniões, e eventualmente, confecção de minutas de editais, contratos e convênios (BRASIL, 2013b). No assessoramento a responsabilidade do membro da AGU é orientar a instância decisória, não cabendo-lhe portanto a responsabilização pela decisão a ser tomada pelo funcionário público orientado.

A consultoria jurídica é a "atividade que responda formalmente a consulta que verse sobre incerteza quanto à aplicação ou à interpretação de normas jurídicas” (BRASIL, 2017c). Nessa modalidade, o advogado emite pareceres que expressam a vontade estatal, os quais devem ser acatados sob pena de nulidade do ato (MACEDO, 2008; p. 46).

Contemporaneamente, um dos maiores desafios da AGU está no exercício do planejamento e implementação de medidas de caráter preventivo capazes de propiciar o controle mais efetivo da atuação da Administração Federal, reduzir as perdas patrimoniais e o volume das ações judiciais (BRASIL, 2013).

Objetivando estabelecer compromissos para combater a morosidade dos processos judiciais, em 2004 deu-se o início da Reforma do Poder Judiciário à luz da Emenda Constitucional no 45 (BRASIL, 2004b) e o advento do "Pacto de Estado em Favor de um Judiciário mais Rápido e Republicano" (BRASIL, 2004a). O referido Pacto de Estado confere à Advocacia-Geral da União a competência de coordenar os esforços visando à diminuição do 
volume de ações de instituições públicas na Justiça brasileira, por intermédio da prevenção da multiplicação de demandas em torno do mesmo tema e da promoção da coerência entre a atuação do Poder Executivo e as diretrizes já pacificadas no Supremo Tribunal Federal e nos Tribunais Superiores (BRASIL, 2004a).

De acordo com Chiavenato (2011, p. 159), o planejamento define onde se pretende chegar, o que deve ser feito, quando, como e em que sequência. Desta forma, faz-se necessário definir os objetivos, diagnosticar o status da situação atual, desenvolver premissas sobre as condições futuras, identificar os meios para alcançar os objetivos e implementar os planos de ação necessários. As metodologias utilizadas para Elaboração do Planejamento Estratégico da Advocacia-Geral da União, no âmbito da Secretaria Geral de Administração (SGA/AGU) e da Coordenação-Geral de Desenvolvimento Organizacional e Riscos (CGDIR), possui como referência a ferramenta denominada Balanced Scorecard. De acordo com Kaplan e Norton (apud BRASIL, 2018d) o Balanced Scorecard (BsC) é um "modelo de gestão estratégica que explicita, comunica, alinha e monitora a estratégia organizacional, traduzindo a missão e a estratégia de uma organização em objetivos e medidas tangíveis e mensuráveis” .

A Advocacia-Geral da União priorizou em seu último Planejamento Estratégico as temáticas de "Prevenção e Redução da Litigiosidade" e "Modernização da Gestão Institucional", visando o gerenciamento dos riscos do contencioso jurídico de modo a buscar a resolução preventiva de conflitos e a uniformização de interpretação da legislação em vigor, bem como implementar um modelo de gestão voltado a resultados alinhados às Diretrizes Estratégicas e à melhoria da prestação de serviços à sociedade (BRASIL, 2009a). Para tanto, estabeleceu-se os seguintes objetivos:

Objetivo 10: Aperfeiçoar os instrumentos que garantam suporte jurídico e administrativo nas fases de elaboração de políticas públicas, em especial, por meio de assessoramento jurídico sobre projetos de lei, medidas provisórias e atos normativos emanados do Poder Executivo Federal, orientando o administrador público, conferindo maior segurança jurídica e prevenindo eventuais litígios nas searas administrativa ou judicial [...]

Objetivo 11: Viabilizar instrumentos que fomentem o intercâmbio de informações entre os órgãos do consultivo e do contencioso, com vistas a prevenir situações de litigiosidade $[\ldots]$

Objetivo 13: Aprimorar mecanismos que possibilitem a identificação da jurisprudência iterativa dos Tribunais Superiores que possam ser objeto de súmula da AGU. Fomentar iniciativas em sede de controle concentrado de constitucionalidade e edição de súmula vinculante em questões de repercussão geral e representativa de controvérsia [...]

Objetivo 16: Implementar modelo dinâmico de gerência, controle, otimização, integração e sustentabilidade dos processos operacionais e de gestão. 
No que tange ao aprimoramento dos instrumentos jurídicos e administrativos pertinentes às fases de formulação, implementação e controle das políticas públicas, nota-se que a AGU se utiliza de ferramentas da advocacia preventiva à luz da escola norte-americana Direito Preventivo (BROWN, 1971), ao adotar uma perspectiva que prioriza a gestão de riscos, enfatizando a necessidade do advogado público antever, antecipar, prevenir e solucionar problemas, ao invés de apenas focar suas atividades no processo judicial. Nessa seara, a AGU trata da advocacia preventiva como instrumento de defesa do interesse público, cuja concreta individualização só pode ser encontrada no próprio Direito Positivo (BANDEIRA DE MELLO, 2002; p. 77).

Paralelamente, pode-se inferir que a AGU se vale também das premissas da escola canadense do Direito Preventivo (NOREAU, 1993) pois, no que diz respeito ao objetivo de expandir a atuação conciliatória na solução de conflitos, a instituição legitima a prática das Resoluções Alternativas de Disputas (RADs) por intermédio dos instrumentos de negociação, mediação e conciliação, conforme excerto do Planejamento Estratégico da AGU abaixo citado:

Objetivo 12: Solucionar conflitos, por meio de alternativas inovadoras, de autocomposição, como a negociação e a mediação/conciliação, existentes entre órgãos e entidades da Administração Pública Federal e entre estes e os Estados da Federação. Ampliar, a médio prazo, a atuação conciliatória para os municípios administrados [...] (BRASIL, 2009a).

$\mathrm{Na}$ esfera da Advocacia-Geral da União, os mecanismos de Resoluções Alternativas de Disputas (RADs) caracterizam-se como aqueles que se propõem a solucionar conflitos já instalados, enquanto que os mecanismos de advocacia preventiva são aqueles que procuram evitar os conflitos.

Para fins de cumprimento da agenda mundial da Cúpula das Nações Unidas, a partir de 2016 a Advocacia Geral da União atrelou suas metas constantes do Plano Plurianual (PPA 2016-2019) aos “Objetivos de Desenvolvimento Sustentável” (ODS), na esfera dos objetivos de "Paz, Justiça e Instituições Fortes". Há de se observar que no âmbito do Plano Plurianual de 2016 à 2019 (BRASIL, 2016a), a Advocacia Geral da União tem como meta "Reduzir a litigiosidade no Poder Judiciário nas ações judiciais em que a União e suas Autarquias e Fundações figurem como partes”. Nesse sentido, Relatório de Avaliação do PPA 2016-2019 (ano base 2016) afirma que: 
Foi editada a Portaria 487/2016, que consolidou os diversos normativos relacionados à redução de litígios no âmbito da Procuradoria Geral da União estabelecendo os procedimentos a serem adotados em caso de reconhecimento da procedência do pedido, abstenção de contestação e de recurso e desistência de recurso conforme entendimentos vinculantes da administração pública e do Poder Judiciário. (BRASIL, 2018c).

Segundo o documento intitulado "Espelho do Monitoramento PPA 2016" (BRASIL, 2017b), a Advocacia-Geral da União já executou as seguintes iniciativas de advocacia preventiva até outubro de 2017:

a) Divulgação de 08 orientações em matéria constitucional e proposição de edição de súmula acolhida pelo Advogado-Geral da União (súmula AGU 81);

b) Edição do Ato Regimental AGU nº 01/2016, institucionalizando as Câmaras Regionais e Nacional de Uniformização de Entendimento Consultivo, visando a prevenção e solução de eventuais divergências de entendimentos jurídico-consultivo; c) Realização de 14 eventos de capacitação sobre os temas Conciliação, Mediação, Negociação e Arbitragem, com carga horária total de 105h/a.

d) Oferta de 833 vagas para cursos e capacitação de 445 pessoas, entre membros das carreiras jurídicas e servidores da AGU e de entidades parceiras;

e) Edição da Portaria $n^{0}$ 487/2016, que com a consolidação de atos normativos concernentes à redução de litígios no âmbito da PGU, de modo a estabelecer procedimentos a serem adotados quando do reconhecimento da procedência do pedido, abstenção de contestação e de recurso e desistência de recurso conforme entendimentos vinculantes da Administração Pública e do Poder Judiciário;

f) Edição da Portaria n ${ }^{0}$ 04/2016/PGU, com a criação dos Núcleos de Atuação Estratégica em Casos Repetitivos (NUCRE), objetivando acompanhar os processos com potencial de massificação;

g) Desenvolvimento das Centrais de Negociação instituídas pela Portaria PGU n ${ }^{\circ}$ 02/2012, visando aperfeiçoar os mecanismos e procedimento de prevenção e solução de conflitos, com o objetivo de reduzir os estoques de processos judiciais da União, os custos judiciais com correção monetária e juros de mora decorrentes da longa duração dos processos no Sistema Justiça e os custos administrativos dos Sistemas Justiça e AGU.

Visando cumprir a meta Plano Plurianual de 2016 à 2019 (BRASIL, 2016a), a AGU pretende racionalizar e otimizar as atividades de contencioso por intermédio do 
aperfeiçoamento do relacionamento da Procuradoria Geral Federal com as entidades assessoradas. (BRASIL, 2017b).

Nesse estudo destacamos os projetos e programas da Advocacia Geral da União que, em alguma medida, apresentam ações de advocacia preventiva (em que pese, em alguns casos, não seja esse seu principal escopo), e que conquistaram notável reconhecimento por intermédio de prêmios e menções honrosas nacionais e internacionais, conforme descrição abaixo em ordem cronológica:

a) Grupo Permanente de Atuação Proativa: Concebido no ano de 2008, o programa tem como objetivo "buscar a recuperação judicial de valores desviados dos cofres públicos federais, a partir de constatações realizadas pelos órgãos de controle da União, como a Controladoria-Geral da União, o Tribunal de Contas da União, o Departamento de Polícia Federal, dentre outros" (BRASIL, 2018b). Como medida de prevenção à litígios, os Advogados da União que compõem o grupo devem submeter à determinadas autoridades propostas de termos de ajustamento de conduta, para prevenir ou terminar litígios que envolvam ação civil pública, ação de improbidade administrativa, ação popular, ação de execução de julgados do Tribunal de Contas da União ação de ressarcimento ao Erário decorrente de atos de improbidade ou cuja recomposição seja superior a um milhão de reais (BRASIL, 2008a). Dentre os princípios deste programa, destaca-se o princípio da proatividade, que consiste na "atuação persistente, por meio de medidas antecipativas, preventivas e construtivas, independentemente de provocação externa" (GONÇALVES, 2017; p. 35). Em 2011 o programa foi vencedor da Categoria Especial do Prêmio Innovare na modalidade "Combate ao Crime Organizado" e no ano seguinte, promoveu um acordo com o Grupo OK visando a restituição de cerca de $\mathrm{R} \$ 468$ milhões aos cofres públicos, o que se caracterizou como a maior recuperação de dinheiro público da História do Brasil (BRASIL, 2011a; GONÇALVES, 2017). Com este feito, o programa conquistou menções honrosas das Organizações das Nações Unidas (ONU) e do governo norteamericano no ano de 2011;

b) Prêmio PGU InovAção: Entre os anos de 2010 a 2014, a Procuradoria Geral da União (PGU) manteve esse projeto com o objetivo de identificar, premiar e divulgar as práticas inovadoras "elaboradas e executadas por servidores administrativos ou Advogados da União, que contribuam para o aumento da eficiência e da qualidade do 
ambiente de trabalho da Advocacia-Geral da União" (ANAUNI, 2011). Como resultado, algumas ações de advocacia preventiva foram premiadas, com destaque para o programa intitulado "Palestras sobre Contratos de Terceirização e a Nova Interpretação Constitucional da Súmula 331", desenvolvido pela ProcuradoriaRegional da União da $2^{\text {a }}$ Região, Procuradoria-Seccional da União em Niterói e Consultoria Jurídica da União, com o objetivo de "diminuir o número de condenações da União na Justiça Trabalhista em decorrência da má gestão dos contratos terceirizados [...] melhorar a fiscalização e a elaboração dos contratos firmados pelo Poder Público [...] e aprimorar a imagem institucional da PGU junto aos órgão federais" (BRASIL, 2012b);

c) Programa de Redução de Litígios e de Aperfeiçoamento da Defesa Judicial da União: Concebido em 2012 pela Coordenação-Geral de Gestão Judicial da Procuradoria-Geral da União, o programa tem como objetivo reduzir os litígios por intermédio da extinção de recursos judiciais interpostos pela União, bem como aperfeiçoar a defesa judicial da União utilizando-se da racionalização da atuação dos Advogados da União na defesa judicial dos interesses da União em consonância com a incrementação do índice de decisões judiciais favoráveis à União, tendo como resultado a geração de economia ao erário ( BRASIL, 2014a). No período entre 2012 a 2015, mais de 108 mil recursos deixaram de ser apresentados pela Advocacia-Geral da União (AGU) nos tribunais regionais federais e Superior Tribunal de Justiça (STJ) e 53.090 processos judiciais foram extintos nesse período, representando uma economia de quase R\$ 25 milhões aos cofres públicos (BRASIL, 2015a). Em 2015 conquistou o Prêmio Innovare, que visa "identificar, divulgar e difundir práticas que contribuam para o aprimoramento da Justiça no Brasil" (INSTITUTO INNOVARE, 2018a);

d) Centrais de Negociação: Em 2015 o projeto do Departamento de Estudos Jurídicos e Contencioso Eleitoral da Procuradoria-Geral da União (DEE/PGU/AGU) foi o vencedor da categoria "Prêmio Especial" da 12 edição do Prêmio Innovare. As “Centrais de Negociação" da AGU "são núcleos permanentes de fomento e operacionalização de conciliações no âmbito da Procuradoria-Geral da União (e respectivas unidades), com vistas a promover acordos com as partes em processos 
repetitivos da União" (INSTITUTO INNOVARE, 2018b). Somente em 2014, a iniciativa economizou cerca de R\$ 126 milhões ao erário (BRASIL, 2015b), e

e) Matriz de Indicadores: Trata-se de um conjunto de gráficos e tabelas que comunicam os indicadores de resultado e desempenho de cada Departamento e órgão de execução da Procuradoria Geral da União (PGU). O projeto foi desenvolvido pela Coordenação-Geral de Informações Estratégicas e pela Coordenação-Geral de Gestão Judicial da PGU. A partir da gestão dos dados gerenciais, a matriz auxiliou na priorização das informações a serem utilizadas e na análise jurimétrica dessas informações, ambas direcionadas à obtenção de resultados (WATANABE, 2013). O projeto ficou entre os dez primeiros finalistas do Concurso de Boas Práticas da Controladoria-Geral da União no ano de 2013 (BRASIL, 2013)

\section{Considerações finais}

Em todo o mundo, tanto no setor privado quanto no público, a ênfase tem sido ultimamente sobre a importância do planejamento antecipado, evitando e gerenciando litígios. A advocacia preventiva assume que quanto maior o uso de estratégias de prevenção de litígios, menor é a necessidade de fazer uso do litígio para resolver controvérsias. A advocacia preventiva é um instrumento que aplica práticas jurídicas consistentes para criar fatos futuros e planejar condutas futuras ao invés de aplicar normas jurídicas aos fatos que aconteceram no passado. Essa perspectiva se baseia em uma forte convicção de que o conhecimento jurídico está no seu melhor quando aplicado antes de as coisas darem errado (HAAPIO, 2010).

A pesquisa indica que a ênfase atual da advocacia preventiva na AGU ainda está focada na solução alternativa de controvérsias (mediação, negociação, arbitragem, conciliação, ajustamento de condutas), não na conformidade dos atos estatais à lei. Não foram identificadas metodologias que permitam abordar esses aspecto. Desse modo, um campo para pesquisa posterior estaria justamente nessa lacuna. Os métodos das demais ciências, como a engenharia, a contabilidade e a administração podem fornecer caminhos promissores.

\section{Referências bibliográficas}


ABREU, L. Direito proativo: uma abordagem estratégica do Direito. Disponível em: < https://jus.com.br/artigos/55816/direito-proativo-uma-abordagem-estrategica-do-direito>. Acesso em: 03 mai 2015.

ALBUQUERQUE, M. A. Advocacia preventiva : sua importância na gestão estratégica da empresa e na prevenção de litígios. Trabalho de Conclusão de Curso (graduação) Universidade Federal do Ceará, Faculdade de Direito, Curso de Direito, Fortaleza, 2016.

ANAUNI. Associação Nacional dos Advogados da União. PGU Inovação: práticas inovadoras são premiadas. 2011. Disponível em: < http://www.anauni.org.br/?p=832> . Acesso em 04 mai 2018.

BANDEIRA DE MELLO, C. A. Curso de Direito Administrativo. 14. ed. rev. e atual. São Paulo: Malheiros, 2002.

BRASIL. Constituição da República Federativa do Brasil. Brasília, DF: Senado Federal: Centro Gráfico, 1988. 292 p. Disponível em:

$<$ http://www.planalto.gov.br/ccivil_03/constituicao/constituicao.htm >. Acesso em 05 mai 2018.

. Emenda Constitucional no 45, de 30 de dezembro de 2004. Altera dispositivos dos arts. $5^{\circ}, 36,52,92,93,95,98,99,102,103,104,105,107,109,111,112,114,115,125,126$, 127, 128, 129, 134 e 168 da Constituição Federal, e acrescenta os arts. 103-A, 103B, 111-A e 130-A, e dá outras providências. Diário Oficial da União, 31 dezembro 2004(b). Disponível em: $<$ http://www.planalto.gov.br/ccivil_03/constituicao/emendas/emc/emc45.htm>. Acesso em 01 mai 2018.

Lei Complementar n. 73, de 10 de fevereiro de 1993. Institui a Lei Orgânica da Advocacia-Geral da União e dá outras providências. 1993. Disponível em: $<$ http://www.planalto.gov.br/ccivil_03/leis/lcp/lcp73.htm>. Acesso em: 10 mai. 2018. 
. Lei n. 8.906, de 4 de julho de 1994. Dispõe sobre o Estatuto da Advocacia e a

Ordem dos Advogados do Brasil (OAB). Disponível em: <

http://www.planalto.gov.br/ccivil_03/leis/L8906.htm>. Acesso em 13 mai 2018.

. Lei no 13.249 de 13 de janeiro de 2016. Institui o Plano Plurianual da União para o período de 2016 a 2019. Diário Oficial da União, 14 janeiro 2016(a). Disponível em: $<$ http://www.planalto.gov.br/ccivil_03/_ato2015-2018/2016/lei/L13249.htm>.

. Lei n. 13.140, de 26 de junho de 2015. Dispõe sobre a mediação entre particulares como meio de solução de controvérsias e sobre a autocomposição de conflitos no âmbito da administração pública; altera a Lei ${ }^{\circ} 9.469$, de 10 de julho de 1997 , e o Decreto $\mathrm{n}^{\circ} 70.235$, de 6 de março de 1972; e revoga o $\S 2^{\circ}$ do art. $6^{\circ}$ da Lei $\mathrm{n}^{\circ}$ 9.469, de 10 de julho de 1997. 2015c. Disponível em: <http://www.planalto.gov.br/ccivil_03/_ato2015-2018/2015/lei/113140.htm>. Acesso em 13 mai 2018.

. Ministério da Justiça. Pacto de Estado em favor de um Judiciário mais rápido e republicano. Diário Oficial da União, 15 dezembro 2004(a). Disponível em:

$<$ https://www.jusbrasil.com.br/diarios/843089/pg-8-secao-1-diario-oficial-da-uniao-dou-de16-12-2004?ref=previous_button>. Acesso em 01 mai 2018.

. Advocacia Geral da União. Portaria n ${ }^{0} 15$ de 25 de setembro de 2008. Criação de grupos permanentes de atuação pró-ativa no âmbito das Procuradorias-Regionais da União, Procuradorias da União e Procuradorias-Seccionais da União. 2008(a). Disponível em: $<$ http://www.agu.gov.br/atos/detalhe/30506>. Acesso em 05 mai 2018.

Advocacia-Geral da União vence prêmio pela atuação de destaque na

recuperação de verbas desviadas em corrupção. 2011(a) Disponível em:<

http://www.agu.gov.br/noticia/advocacia-geral-da-uniao-vence-premio-innovare-pelaatuacao-de-destaque-na-recuperacao-de-verbas-desviadas-em-corrupcao $>$. Acesso em 05 mai 2018.

Diretrizes estratégicas: 2008-2015. Brasília, Distrito Federal, 2009(a).

Disponível em: <http://www.agu.gov.br/page/content/detail/id_conteudo/266959>. Acesso em: 06 mai 2018. 
. Histórico e evolução da Advocacia Geral da União. Atualizado em 25 de abril de 2013 (a). Disponível em:

$<$ http://www.agu.gov.br/page/content/detail/id_conteudo/200644>. Acesso em 01 mai. 2018.

. PGU é finalista do concurso da Controladoria-Geral da União por

projeto Matriz de Indicadores. Atualizado em $04 \mathrm{dez}$ 2013. Disponível em:

<http://www.agu.gov.br/page/content/detail/id_conteudo/262067>. Acesso em 15 mai 2018.

. Iniciativa da AGU para reduzir litigiosidade vence Prêmio Innovare.

2015(b). Disponível em: <http://www.agu.gov.br/noticia/iniciativa-da-agu-para-reduzirlitigiosidade-vence-premio-innovare>. Acesso em 05 mai 2018.

\section{. Programa de redução de litígios da AGU vence prêmio na área de}

gestão. 2015(a) Disponível em:

$<$ http://www.agu.gov.br/page/content/detail/id_conteudo/322977>. Acesso em 05 mai 2018.

. Escola da Advocacia-Geral da União Ministro Victor Nunes Leal.

Conheça o Grupo Permanente de Atuação Pró-Ativa da AGU. Disponível em: < http://www.agu.gov.br/page/download/index/id/10606595>. Acesso em 05 mai 2018(b).

. Procuradoria Geral da União. PGU Inovação. $3^{\text {a }}$ Edição. Palestras sobre

Contratos de Terceirização e a Nova Interpretação Constitucional da Súmula 331. 2012(b) Disponível em: <www.agu.gov.br/page/download/index/id/12807101>. Acesso em 06 mai 2018.

. Procuradoria-Geral Federal. Portaria no 526 de 26 de agosto de 2013(b).

Estabelece diretrizes gerais para o exercício das atividades de consultoria e assessoramento jurídicos prestadas às autarquias e fundações públicas federais. Disponível em: $<$ http://www.agu.gov.br/atos/detalhe/984974>. Acesso em 13 mai 2018.

_.___. Procuradoria Federal junto à Universidade Federal de Santa Catarina. Portaria $n^{\circ}$ 1/2017/PFUFSC/GR, de 13 de abril de 2017(c). Estabelece o protocolo de relacionamento entre a Universidade Federal de Santa Catarina e a Procuradoria Federal 
junto à Universidade Federal de Santa Catarina. Disponível em:

$<$ http://www.agu.gov.br/page/content/detail/id_conteudo/640405>. Acesso em 13 mai 2018. . Secretaria Geral de Administração. Planejamento estratégico da Secretaria-

Geral de Administração. Guia: Revisão, Elaboração, Execução, Monitoramento \& Avaliação. Brasília, mai. 2016. Disponível em:

$<$ http://www.agu.gov.br/page/content/detail/id_conteudo/518591>. Acesso em: 05 mar. 2018(d).

. Conselho da Justiça Federal. Sobre o Centro Nacional de Inteligência da Justiça

Federal. Disponível em: <http://www.cjf.jus.br/centrodeinteligencia/sobre.php >. Acesso em: 30 Abr. 2018(a).

. Conselho Nacional de Justiça. 100 Maiores Litigantes. Brasília: CNJ, 2012(a).

Disponível em:

$<$ http://www.cnj.jus.br/images/pesquisasjudiciarias/Publicacoes/100_maiores_litigantes.pdf $>$. Acesso em: 02 mai 2018.

. Justiça em Números 2017: ano-base 2016. Brasília: CNJ, 2017(a).

. Painel de Consulta ao Banco Nacional de Demandas Repetitivas e Precedentes Obrigatórios. 2018e. Disponível em:

$<$ https://paineis.cnj.jus.br/QvAJAXZfc/opendoc.htm?document=qvw_1\%2FPainelCNJ.qvw\& host=QVS\%40neodimio03\&anonymous=true\&sheet=shDRGraficos $>$. Acesso em: 15 mai. 2018.

. Ministério do Planejamento, Orçamento e Gestão. Escola Nacional de Administração Pública. Ações Premiadas no $19^{\circ}$ Concurso Inovação na Gestão Pública Federal (2014). Brasília: ENAP, 2014(a).

PPA 2016-2019: Relatório Anual de Avaliação. Plano Plurianual. Ano base: 2016(b). Disponível em: <http://www.planejamento.gov.br/assuntos/planeja/planoplurianual/relatorio_final.pdf/view>. Acesso em 14 mai 2018. 
Espelho do Monitoramento PPA 2016. Programa: 2038 Democracia e Aperfeiçoamento da Gestão Pública. Data da Consulta: 10 out. 2017(b). Disponível em: <www.agu.gov.br/page/download/index/id/38231869>. Acesso em 06 mai 2018.

PPA Cidadão. ODS 16 - Paz, Justiça e Instituições Fortes. Disponível em: $<$ https://ppacidadao.planejamento.gov.br/sitioPPA/paginas/agendas-transversais/metasiniciativas. $x$ tml objetivo=1043\&agenda $=283 \&$ ep $=1>$. Acesso em 06 mai 2018(c).

BROWN, L. M.: Preventive law and the legal assistant. Vanderbilt Law Review. Volume 24, p. 1181. Ano: 1971. Disponível em:

$<$ http://heinonline.org/HOL/LandingPage?handle=hein.journals/vanlr24\&div=65\&id=\&page $=>$. Acesso em 02 mai 2018 .

. Preventive law. Prentice-Hall, Inc. New York, 1950

CARVALHO, H. G; SANTOS, N. A estreita relação entre gestão do conhecimento e inteligência competitiva. In: Anais - I Workshop Brasileiro de IC e GC, 1999.

CHIAVENATO, Idalberto. Introdução à teoria geral da administração. $8^{\mathrm{a}} \mathrm{Ed}$. Rio de Janeiro: Elsevier, 2011.

FERENHOF, H. A.; FERNANDES, R. F. Passos para a construção da revisão sistemática e bibliometria. Disponível em: <http://www.igci.com.br/artigos/passos_rsb.pdf > Acesso em: 13 mai. 2018.

GONÇALVES, M. D. P. A Concepção de um sistema de informação para a gestão das ações de prevenção e combate à corrupção: Estudo de caso na Procuradoria-Geral da União. Tese (Doutorado - Doutorado em Ciência da Informação) -- Universidade de Brasília, 2017. Disponível em:

$<$ www.repositorio.unb.br/bitstream/10482/24598/1/2017_MarcioDenysPessanhaGonçalves.p df >. Acesso em 06 mai. 2018 
HAAPIO, H. Introduction to proactive law: A Business Lawyer's View. Stockholm Institute for Scandinavian Law. The Stockholm University Law Faculty. Stockholm, 2010. Disponível em: <http://www.scandinavianlaw.se/pdf/49-2.pdf>. Acesso em 02 Mai. 2018.

INSTITUTO INNOVARE. O prêmio. Disponível em:

$<$ http://www.premioinnovare.com.br/inscricoes >. Acesso em 05 mai 2018 (a).

. Centrais de negociação. Disponível em:

$<$ http://www.premioinnovare.com.br/praticas/1/centrais-de-negociacao-cnpgu $>$. Acesso em 05 mai 2018(b)

MACEDO, R. Advocacia-Geral da União na Constituição de 1988. São Paulo: LTr. 2008.

MOREIRA NETO, D. F.; ALMEIDA, A. P. C. B. C.; GARCIA, F. A. O Futuro da Advocacia Pública: A ação preventiva e proativa. Revista Jurídica da Procuradoria-Geral do Estado do Paraná, Curitiba, n. 7, p. 11-36, 2016. Disponível em:

$<$ http://www.pge.pr.gov.br/arquivos/File/OFuturodaAdvocaciaPublicaAAcaoPreventivaeProa tiva.pdf $>$. Acesso em 01 mai. 2018.

NOREAU, P. Droit préventif: le droit au-delà de la loi. Faculté de Droit, Université de Montréal. Éditions Thémis. Quebéc, 1999. Disponível em:

$<$ https://papyrus.bib.umontreal.ca/xmlui/bitstream/handle/1866/82/0048.pdf $>$. Acesso em 02 mai 2018.

OAB. Ordem dos Advogados do Brasil. Conselho Federal da OAB. Resolução no 02/2015. Aprova o Código de Ética e Disciplina da Ordem dos Advogados do Brasil - OAB.

Disponível em: $<$ http://www.oabsp.org.br/subs/pacaembu/institucional/codigo-de-etica-edisciplina-da-oab>. Acesso em 15 mai 2018.

SILVA, R. P. O trabalho repetitivo no âmbito do contencioso judicial e os riscos à saúde do procurador do Estado. Revista da Procuradoria Geral do Estado de Santa Catarina. n. 5. p. 171 - 193. Florianópolis: DIOESC, 2016. Disponível em: $<$ http://www.pge.sc.gov.br/images/pdfs/Revista.pdf>. Acesso em 04 mai 2018. 
WATANABE, E. A gestão por resultados da procuradoria-geral da união. Revista da AGU, v. 12, n. 38, p. 9-38, out./dez., 2013. Disponível em:

$<$ http://www.seer.ufrgs.br/ConTexto/article/viewFile/67636/pdf>. Acesso em 15 mai 2018. 


\title{
NOVAS FORMAS DE PACTUAÇÃO NOS CONTRATOS PÚBLICOS E A NECESSIDADE DE PROTEÇÃO DO USUÁRIO DE SERVIÇO PÚBLICO
}

\author{
Anna Dolores Barros de Oliveira Sá \\ Universidade Católica de Pernambuco \\ Alberto Jonathas Maia De Lima \\ Universidade Católica de Pernambuco
}

\begin{abstract}
Resumo
Trata-se de estudo sobre os Serviços públicos no Brasil e a técnica de exploração privada, atualmente, na sua execução. Apresenta-se uma breve análise histórica, bem como a conceituação do tema central. O corte epistemológico ocupa-se das particularidades dos serviços públicos através da exploração privada, o trabalho mostra que a expansão das formas de gestão privada dos serviços públicos representa uma tendência contemporânea de gestão pública. Por fim, passa-se a considerar a Lei Federal 13.460/2017 como forma de resguardar o cidadão que tiver o acesso a esses serviços lesados.
\end{abstract}

Palavras-chave: Cidadão, Gestão Pública, Exploração privada, Execução, Serviço Público.

\begin{abstract}
Resumen/Résumé
It is a study about the Public Services in Brazil and the technique of private exploitation, currently, in its execution. It presents a brief historical analysis, as well as the conceptualization of the central theme. The epistemological cut deals with the peculiarities of the public services through the private exploitation, the work shows that the expansion of the forms of private management of the public services represents a contemporary tendency of public management. Finally, Federal Law 13,460 / 2017 is considered as a way to protect the citizen who has access to these services injured.
\end{abstract}

Keywords/Palabras-claves/Mots-clés: Citizen, Public administration, Private Exploration, Execution, Public service. 


\section{Introdução}

Dizer que o direito administrativo está vivenciando profundas modificações é como referir a inexorável passagem do tempo e a força natural que coloca todas as coisas em constante movimento, por isso vamos começar esse ensaio observando outras premissas e realçar a influência do neoconstitucionalismo, bem como o protagonismo dos contratos públicos na lapidação das mais recentes transformações dessa área de conhecimento jurídico. ${ }^{1}$

A intimidade das relações interdisciplinares travadas entre o direito constitucional e o direito administrativo acaba determinando um terminal comum para as aspirações evolutivas do direito público, por isso é natural que a efetividade dos direitos fundamentais seja o principal problema enfrentado pelo Estado de direito no despontar do século XXI. ${ }^{2}$

A influência do neoconstitucionalismo nos institutos do direito administrativo é crucial para potencializar a força normativa dos princípios constitucionais, e o direito público subjetivo de acesso ao serviço público, pois a noção de supremacia e a centralidade da Constituição no ordenamento jurídico brasileiro apoiam as decisões judiciais, que servem o direito fundamental cotidiano dos jurisdicionados em busca de justiça. ${ }^{3}$

Nesse ponto, a teoria da constituição serve de base para a judicialização de políticas públicas sociais que interferem na concretização de direitos fundamentais de caráter social, sobretudo aqueles materializados com a prestação de serviços públicos como educação, saúde, energia elétrica, abastecimento de água, dentre outros. É importante destacar que o Poder Judiciária também se opõe a concessão de direitos com base na Constituição. ${ }^{4}$

\footnotetext{
${ }^{1}$ Rafael Garofano coloca o contrato no centro das relações do Estado identificando nesse instrumento várias aplicações como: a prestação de serviços públicos, a cooperação federativa, a desburocratização, o fomento de atividades econômicas e sociais, o fornecimento de bens, serviços e obras de engenharia, a negociação internacional, o controle e dentre outras possibilidades. GAROFANO, Rafael Roque. Contratualidade administrativa: abrangência e complexidade do fenômeno contratual da Administração Pública. Rio de Janeiro: Lumen Juris, 2015, p. 121-223.

${ }^{2}$ Schmidt-Assmann realça o significado e o alcance do direito administrativo como sistema referindo o direito administrativo como direito constitucional concretizado e enfatizando o papel do direito constitucional com receptor de novas tendências capazes de promover a legitimidade da Administração Pública, por isso "el Derecho administrativo representa el campo de verificación y experimentación del Derecho constitucional." SCHMIDTASSMANN, Eberhard. La teoía general del derecho administrativo como sistema. Barcelona, Marcial Pons, 2003, p. 17.

3 GUERRA FILHO, Willis Santiago. Filosofia do direito aplicada ao direito processual e à teoria da Constituição. $2^{\mathrm{a}}$ ed. Atlas, 2002, p. 32.

${ }^{4}$ A angustia do Poder Judiciária diante do controle das políticas públicas no Brasil é referida por Arthur Badin em estudo sobre o panorama de argumentação das decisões judiciais voltadas a positivação ou negação de direitos fundamentais com título curioso: "entre o Don Quixote e o Pôncio Pilatos.” BADIN, Arthur Sanchez. Controle judicial das políticas públicas: contribuição ao estudo do tema judicialização da política pela abordagem da análise institucional comparada de Neil K. Komesar. São Paulo: Malheiros, 2013, p. 54-67. Noutro ponto, o problema a posição hiperativa do Poder Judiciário, em decisões passíveis de quebrar o equilíbrio entre os poderes da república, pois a efetividade de direitos fundamentais dos jurisdicionados depende da concretização da tutela
} 
O Poder Judiciário já consolidou seu papel como guardião dos direitos fundamentais de caráter prestacional e o debate não diz mais respeito à possibilidade de salvaguarda dos direitos, pois estamos vivendo um momento de reflexão sobre a medida da toga que os juízes podem vestir, diante de intensas críticas a proliferação de sentenças, onde o Juiz ora legisla no lugar do legislativo, ora administra no lugar do Executivo. ${ }^{5}$ Até aqui, a notícia sobre o tempo de esplendor dos direitos sociais não se constitui como premissa de inovação do direito público no Brasil, pois os reflexos do neoconstitucionalismo na efetivação dos direitos fundamentais de segunda geração se revelam já no final dos anos 1990, contudo o fenômeno, que pode surpreender observadores da ciência jurídica diz respeito ao papel dos contratos públicos na positivação de standards levantados pela Constituição mexicana de 1917 e pela constituição de Weimar em 1919.

Os contratos públicos possuem uma formatação repleta de novidades porque há modalidades de acordo muito jovens - algumas com pouco mais de dez anos no direito administrativo brasileiro, como o contrato de programa, o contrato de rateio, a concessão administrativa, a concessão patrocinada, o termo de fomento, o termo de colaboração e o acordo de cooperação.

Contudo não podemos supor que as roupagens tradicionais de contrato público foram simplesmente recicladas ou ampliadas, pois há um movimento que impulsiona uma reordenação mais profunda, capaz de tocar o Poder Público, dantes senhor absoluto da situação, com a primazia para definir o objeto dos pactos, sempre munido da posição de supremacia, gravada nas cláusulas exorbitantes. ${ }^{6}$

resguardada pela sentença, ou seja, "Em suma, hacer cumplir de manera cabal uma sentencia adversa a la Administración pública es hacer honor a la legitimidad del actuar administrativo y a los derechos de la persona." GUERRÓN, Juan Carlos Benalcázar. La ejecución de la sentencia em lo processo contencioso-administrativo. In: GAMBOA, Jaime Orlando Santofimio; VÁSQUEZ, Javier Barnés; IBAGÓN, Mónica Liliana Ibagón. (EDS. ). Persperctivas de uma reforma: estúdios de derecho administrativo a partir de la obra de Eberhard Schmidt Assmann. Bogotá: Universidad Externado de Colombia, 2016, p. 177.

5 "Inúmeras críticas têm sido dirigidas a essa expansão do Poder Judiciário. A primeira delas é de natureza política: magistrados não são eleitos e, por essa razão, não deveriam poder sobrepor sua vontade à dos agentes escolhidos pelo povo. A segunda é uma crítica ideológica: o Judiciário seria um espaço conservador, de preservação das elites contra os processos democráticos majoritários. Uma terceira crítica diz respeito à capacidade institucional do Poder Judiciário, que seria reparado para decidir casos específicos, e não para avaliar o efeito sistêmico de decisões que repercutem sobre políticas públicas gerais. E, por fim, a judicialização reduziria a possibilidade de participação da sociedade como um todo, por excluir os que não têm acesso aos tribunais. BARROSO, Luís Roberto. O novo direito constitucional brasileiro: contribuições para a construção teórica e prática da jurisdição constitucional no Brasil. $1^{\text {a }}$ reimpressão. Belo Horizonte: Fórum, 2013, p. 40.

${ }^{6}$ Reflexos do questionamento sobre a legitimidade das cláusulas exorbitantes nos contratos públicos no Brasil podem ser observados na disciplina das parcerias público-privadas diante da Lei 11.079/2004, que suaviza significativamente as prerrogativas do Poder Público ao estabelecer a hipótese de exigência de garantia da concessionária de serviço público em relação ao concedente, bem como a possibilidade de revisão automática de tarifas e penalidades imputadas ao Poder Público em caso de descumprimento das cláusulas do contrato. Apesar disso, é possível perceber que a raiz do Direito Administrativo, centrado na posição de supremacia do Estado, 
O procedimento de manifestação de interesse está previsto na Lei 13.019/2014 e no PL 559/2013, que propõe a reforma e a unificação do regime de licitações e contratos públicos no Brasil. Nas duas hipóteses o empreendedor, no setor privado, pode formular diagnóstico vinculado à implantação de infraestrutura ou serviço público, e protocolar projeto junto ao Poder Público, solicitando a apreciação, e se for caso, a aprovação para fins de implementação do objeto.

Nenhum administrativista do século XX seria capaz de supor a execução de contrato, cujo objeto não foi proposto, de forma originária, pela Administração Pública, já que não havia um canal de diálogo aberto para um engenho provocado pela iniciativa privada. Nem seria possível o sugestionamento dogmático de uma disciplina contratual com abrandamento do regime jurídico de direito público.

A metodologia da pesquisa, em princípio, possuiu um marco teórico a fim de observar a origem do termo serviço público, o modus operandi do conceito conforme os franceses nos expuseram. E, em um segundo momento, estudaremos a técnica de exploração da inciativa privada no Brasil. Por fim, abordaremos a Lei Federal 13.460/2017 como forma de resguardar o cidadão que tiver o acesso a esses serviços lesados.

\section{Origem do conceito "Serviço Público"}

Conforme preleciona Grotti (2017), a noção de serviço público é antiga e diz respeito a uma atuação prestacional realizada pelo Estado. Como se sabe, em tempos antigos todos estavam submetidos a um ser soberano, o rei. As contribuições, impostos e serviços eram todos direcionados para o sustento da corte. Essa concepção foi aos poucos sendo superada. A autora explica que "o serviço público" pode ser encontrada do Contrato Social de Jean-Jacques Rousseau $^{7}$, a expressão:

\footnotetext{
inclusive com a defesa da manutenção das cláusulas exorbitantes persiste na literatura e no regime jurídico geral dos contratos públicos. SANTOS, Marcia Walquiria Batista dos. Cláusulas exorbitantes: da teoria à prática. In: DI PIETRO, Maria Sylvia Zanella; RIBEIRO, Carlos Vinícius Alves. (Coords.). Supremacia do interesse público e outros temas polêmicos. São Paulo: Atlas, p. 388-393.

${ }^{7}$ No original: Assim que o serviço público cessa de ser a principal preocupação dos cidadãos, ao qual melhor preferem servir com a bolsa que pessoalmente, já se encontra o Estado próximo da ruína. Se é preciso seguir para o combate, eles pagam as tropas e permanecem em casa; se é preciso ir à assembleia, eles nomeiam os deputados e continuam em casa. À força de dinheiro e preguiça, eles dispõem de soldados para servir a pátria e de representantes para a venderem. 2002, p. 45 .
} 
aparece (...) abrangendo qualquer atividade estatal. E o faz com duas conotações: de um lado, trata-se de atividades destinadas ao serviço do público, isto é, ações através das quais se assegura aos cidadãos a satisfação de uma necessidade sentida coletivamente sem que cada um tenha de atendê-la pessoalmente; de outro, concebese como uma atividade estatal que sucede ao serviço do Rei, porque se operou uma substituição na titularidade da soberania.

E mais, se extrai da obra do filósofo suíço o serviço público era concebido como uma atividade do Estado, uma atividade essencialmente pública direcionada para assistir, satisfazer e acorrer as necessidades coletivas da sociedade.

De fato, o Estado passa a ser considerado como servo do povo e não o contrário; o servitium, que na expressão latina significa escravidão ou servidão que é oferecido é pelo servus faz a locução, em sua etimologia, ter todo sentido.

Com o tempo o Estado assumiu diretamente determinadas tarefas que até então não eram concebidas como estatais - notadamente nas áreas de saúde e educação -, uma vez que eram executadas por determinados setores da sociedade, como o baixo clero representando a Igreja, fundações, corporações e universidades.

Como se observa o serviço concebido como público experimenta transformações diante da dinâmica político-social de cada Estado. E mais, a concepção de serviço público deve ser entendida a partir do modelo econômico adotado pelo Estado. Nesse sentido, o serviço público é constituído, planejado e executado de acordo com o maior ou menor grau de intervenção estatal na sociedade, pois como dito, algumas áreas sempre tiveram a participação de setores privados (DI PIETRO, 2014, p. 100 e ss).

Feitas essas considerações, passa-se a expor as construções doutrinárias que elaboram o conceito de serviço público. Utilizamos como referencial teórico Carvalho Filho (2017) e sua teoria Manual de Direito Administrativo; Zanella de Pietro (2014), que fizeram suas construções antes da promulgação do Código de Defesa do Usuário do Serviço Público, ademais, fizemos essa opção por não existir um conceito doutrinário consensual. Na verdade, existem correntes teóricas que, segundo parâmetros variados, procuram indicar as bases relevantes para a identificação de uma atividade como "serviço público".

José dos Santos Carvalho Filho, após fazer uma breve digressão das concepções trazidas pela doutrina nacional e estrangeira aponta que "o conceito deve conter os diversos critérios relativos à atividade pública" e arremata "conceituamos serviço público como toda atividade prestada pelo Estado ou por seus delegados, basicamente sob regime de direito público, com vistas à satisfação de necessidades essenciais e secundárias da coletividade" (2017, p 336). A professora Maria Sylvia Zanella de Pietro define serviço público como a 
atividade em que a legislação "atribui ao Estado para que a exerça diretamente ou por meio de seus delegados, com o objetivo de satisfazer concretamente às necessidades coletivas, sob regime jurídico total ou parcialmente público" (2014, p. 107).

Dito isto, é possível avançar.

O serviço público está intimamente ligado com a noção de interesse público ou interesse coletivo. O Estado enquanto gestor dos interesses da sociedade, não pode ventilar outro objetivo que não seja o de propiciar a população as melhores condições para que possam usufruir de tais serviços. É claro que existem níveis de prioridade. Nesse sentido José dos Santos Carvalho Filho obtempera que:

\begin{abstract}
A grande diversidade dos interesses coletivos exige sua caracterização em primários ou essenciais, de um lado, e secundários ou não essenciais, de outro. Quando o serviço é essencial, deve o Estado prestá-lo na maior dimensão possível, porque estará atendendo diretamente às demandas principais da coletividade. Inobstante, ainda que seja secundário, a prestação terá resultado de avaliação feita pelo próprio Estado, que, por algum motivo especial, terá interesse em fazê-lo. De uma ou de outra forma, contudo, os serviços públicos hão de vislumbrar o interesse coletivo, seja ele próximo ou remoto. Registre-se, por oportuno, entretanto, que o caráter de essencialidade do serviço não tem parâmetros previamente definidos, variando de acordo com o lugar e o tempo em que a atividade é desempenhada. Com efeito, há países em que um determinado serviço se configura como essencial, ao passo que em outro não passa de atividade secundária. (2017, p. 337-338)
\end{abstract}

No direito brasileiro a prestação do serviço público e as competências para sua prestação possui base constitucional tamanha sua importância. De acordo com o texto constitucional incumbe ao poder público, na forma da lei, diretamente ou sob regime de concessão ou permissão, sempre através de licitação, a prestação de serviços públicos (art. 175, caput) e muito embora não disponha de um conceito fixo, o legislador nos forneceu alguns subsídios que direcionam a área estipulada como própria dos serviços públicos.

Acerca disso Carlos Ari Sundfeld (2012, p. 83-84) explica que "a prestação de tais serviços é dever inafastável do Estado, tendo os indivíduos o direito subjetivo de usufruí-los. $\mathrm{O}$ objetivo de outorgar tais competências ao Poder Público não foi o de reservá-las, mas sim o de obrigar a seu exercício" e também explana os motivos pelos quais determinadas atividades se concentram nas mãos do Estado: "para ordenar o aproveitamento de recursos finitos, controlar a utilização de materiais perigosos, favorecer o rápido desenvolvimento nacional, realizar a justiça social, manter a unidade do país e assim por diante".

$\mathrm{Na}$ Constituição Brasileira de 1988, o legislador optou por dividir determinadas prestação de serviços públicos para a União, Estados e Municípios. 
É o que se nomina reparticipção de competências, a técnica que o legislador constituinte utilizou para distribuir as diferentes atividades a serem prestadas pelos entes da Federação. São atividades de gestão administrativa (SUNDFELD, 2012, p.82), isto é, de atuação execução direta de práticas concernentes às matérias nelas consignadas, como explica José Afonso da Silva (1999, p. 482): “o sistema brasileiro é o de execução imediata. União, Estados, Distrito Federal e Municípios mantém, cada qual, seu corpo de servidores públicos, destinados a executar os serviços das respectivas administrações”.

A Constituição, como não poderia deixar de ser, explicita que determinados serviços poderão ser prestados por terceiros mediante autorização, concessão ou permissão. Sobre esse ponto. José dos Santos Carvalho Filho explica que

\begin{abstract}
Visando a um interesse público, os serviços públicos se incluem como um dos objetivos do Estado. É por isso que são eles criados e regulamentados pelo Poder Público, a quem também incumbe a fiscalização. É claro que as relações sociais e econômicas modernas permitem que o Estado delegue a particulares a execução de certos serviços públicos. No entanto, essa delegação não descaracteriza o serviço como público, vez que o Estado sempre se reserva o poder jurídico de regulamentar, alterar e controlar o serviço. Não é por outra razão que a Constituição atual dispõe no sentido de que é ao Poder Público que incumbe a prestação dos serviços públicos (2017, p. 337-338)
\end{abstract}

Dito isto percebe-se que, para dar capilaridade e amplitude aos serviços públicos em suas diversas áreas, o Estado pode delegar esses serviços para entes particulares, no dizer de Carlos Ari Sundfield "a delegação é o ato administrativo pelo qual a Administração transfere transitoriamente a particular o exercício do direito à exploração do serviço público". O autor explica que o que se outorga é o exercício e não a titularidade assim, "o Estado nunca aliena os interesses públicos; admite-se que apenas que transfira, o exercício das competências voltadas à sua implementação, sem abrir mão delas" (2012, p. 83).

Conquanto possa ser prestada por entes particulares os serviços públicos se submetem, em sua maioria, às normas relativas ao regime de direito público. Deve-se ter em mente que o Estado é o grande remunerador dessas atividades, direciona-se os recursos públicos advindos dos impostos arrecadados para que esses entes sejam remunerados e em contrapartida executem tais serviços. Assim, há um corpo de instrumentos normativos que cuida especificamente das regras aplicáveis aos serviços públicos, notadamente as que dispõe sobre fiscalização, execução e sobretudo a prestação de contas dos recursos aplicados. 


\section{O serviço Público à Francesa}

O Principal expoente intelectual no início do século XX na construção de uma teoria de legitimação do Estado fundada na noção de serviço público deriva da posição dogmática defendida por Leon Duguit. Ele construiu uma doutrina sociológica baseada em Durkheim, registrando que o Estado titulariza uma parcela de prerrogativa justificáveis apenas em função do dever delas decorrente relativo à promoção da solidariedade social. Nessa perspectiva os serviços públicos se constituem como instrumentos de concretização da solidariedade social, com indicação num conjunto de obrigações atribuídas à potestade pública. (POZZO, 2012, p.57-59).

Para Duguit toda a atuação do Estado estaria fundada no dever deste de concretizar a solidariedade social afetando serviços públicos, nesse caso entendidos em sentido amplo, ou seja, como função administrativa, abarcando não só a positividade de utilidade ou comodidade facultativa, como também as tutelas decorrentes do Poder de Polícia e da Intervenção do Estado na Economia.Nessa perspectiva o critério material para a definição do serviço público é a natureza da atividade, concernente a concretização de necessidades da sociedade. (RIBAS, 2007, p. 78). Na obra Serviços públicos dirigidos.

Duguit defendia a maleabilidade da prescrição dos serviços públicos em espécie, alegando que algumas atividades que ainda não eram classificadas como serviço público na época (transporte e energia) deveriam ganhar esse status. Ou seja, serviço público é a atividade imputada ao Estado em função da necessidade que a sociedade apresenta. Essa flexibilidade é abordada na reflexão de Maria Sylvia Zanella Di Pietro (2013, p. 105-106).

Por fim Duguit defende a tese de que o serviço público deve ser ofertado de forma ininterrupta, fundando pressuposto que dá ensejo a fundação do princípio da continuidade disposto no artigo $6^{\circ}$ da Lei $8.987 / 1995$, cujos desdobramentos se verificam, sobretudo, na regulação do direito à greve dos profissionais implicados na sua execução, como se verifica na Lei 7.783/1989. (JUSTEN, 2003, p. 20-21)

De forma paralela a Duguit, Hauriou acabou construindo várias teses distintas sobre o referencial teórico que alicerça a unidade e autonomia do Direito administrativo, no âmbito do direito público. Preliminarmente, no final do século XVIII ele sustenta a ideia de que o direito administrativo se impõe com a força de duas vigas o serviço público (como fim) e a "puissauce publique" como meio.

Como sucessor de Duguit na Escola de Bordeaux, Jèze também enfrentou o tema do serviço público, acrescentando mudanças ao enfoque anterior dado ao tema numa concepção 
mais formalista, Jèze entende que serviço público é a atividade administrativa que recebe tal classificação em função do enquadramento legal conferido pelo legislador. Ou seja, nessa perspectiva serviço público é a atribuição de uma tarefa ao Estado, submetida a regime jurídico de direito público. Para Jèze não importa o dever-ser. O que a sociedade considera necessidade, pois serviço público é o que o legislador interpreta como necessidade da sociedade. (BOURGES, 2006, p.56-57).

As contribuições de Duguit, Hauriou e Jèze para a lapidação da noção de serviço público não decorrem da uniformidade ou suplementariedade relativa à construção de uma tese sobre o cerne do serviço público. O debate, contudo, vale a pena pelos seus confrontos, que são fundamentais para a edificação de uma teoria geral do Direito Administrativo. Com base em Celso Antonio Bandeira de Mello (2005, p.42-43) talvez seja possível declarar que Hauriou venceu a batalha na determinação das bases do direito administrativo contemporâneo, pois tanto a noção de serviço público, como a noção de "puissauce públique" aparecem como eixos de sustentação do ramo do direito público aludido. Nessa perspectiva, as noções que serviram ao embate intelectual entre franceses e alemães não se negam, já que se completam entre si.

O movimento da escola de Bordeaux, pela manutenção da hegemonia da noção de serviço público como base do edifício do direito administrativo, vai perdendo força no final da primeira metade do século XX - aspecto que fomenta a sempre contemplada crise da noção do serviço público.

Nos anos 1950, o final da $2^{\text {a }}$ Guerra Mundial aprofundada a crise elucidada em função da necessidade crescente do Estado, sobretudo numa Europa devastada, assumir o desenvolvimento de atividades administrativas que não se enquadravam na armadura clássica confeccionada por Duguit. Nesse contexto, a construção do conceito contemporâneo de serviço público na atualidade, leva em consideração que as funções administrativas do Estado, do ponto de vista do seu objeto, podem ser enquadradas em três ou quatro categorias, quais sejam: poder de polícia, serviço público, intervenção do Estado no domínio econômico. (FILHO, 2012, p.11).

De fato a importância da noção de serviço público para a apaziguação de conflitos relacionados à competência do conselho de Estado da França é inexorável, e mesmo após o declínio da Escola de Bordeaux não se pode refutar a importância da noção de serviço público para a construção do conceito da atividade administrativa do Estado mais relevante para a promoção do sentimento de bem-estar da sociedade civil em todos os Estados Democráticos de Direito. 


\section{A exploração privada de serviços públicos no Brasil}

Maria Sylvia Zanella Di Pietro (2002) no seu "Parcerias na administração Pública" faz um relato sobre o aspecto dialético da exploração privada de serviços públicos antes da edição da Lei 11079/2004, observando os seguintes contextos:

a. No final do século XIX as primeiras concessões de serviço público empreendidas por Dom Pedro II, para exploração das ferrovias e desova do café no Porto de Santos, decorriam da falta não só de recursos financeiros do Estado, mas também da ausência de Know How da potestade pública para tocar a exploração direta.

b. Nos anos 1930, a era Vargas seria marcada por uma política de fortalecimento da intervenção do Estado na economia que enfatizava a estatização do serviço público e favorecia a criação de entidades públicas para a promoção de atividades voltadas a fundação de uma indústria de base. Por isso um período a exploração privada de serviços públicos decai, sobretudo, porque o governo deflagra uma série de encampações.

c. No período anterior a era Vargas que tem início entre os anos 1950 e 1960 retoma-se a descentralização por delegação contratual, sobretudo, em seguimentos como transporte aeroviário e comunicação social, mas alguns monopólios públicos ainda minimizam a exploração de serviços públicos pelo setor privado.

d. Com o advento da Constituição Federal de 1988, o art. 173 da Carta nos fornecerá o fundamento constitucional de desestatização, ensejando a seguinte produção legislativa: Leis 8.031/1990, 8.987/1995, 9.491/1997. Nesse contexto a privatização nos setores de telefonia e energia elétrica favorecem a expansão da exploração privada de serviços públicos. Mais adiante a Lei 11079/2004 introduz a figura das parcerias público-privadas no Brasil, consolidando um processo que parece enfatizar uma estratégia de gestão público-indireta dos serviços públicos. No seguinte em que estão localizados os serviços públicos econômicos, essa operação é evidente e no que diz respeito aos serviços públicos sociais a promoção velada de um processo de descentralização com eixo no setor privado parece se revelar na expansão de contratos entre Poder Público e o Terceiro Setor, com ênfase para a promoção da saúde.

Tudo indica que a expansão das formas de gestão privada dos serviços públicos representa uma tendência contemporânea de gestão pública - fenômeno que deriva de um movimento de contratualização da Administração Pública. (NETTO, 2005, p 256-266).

De acordo com Marçal Justen Filho (2005, p.506-507) a Constituição Federal de 1988 não apontou um rol taxativo de modelos de delegação de serviço público, chegando mesmo a se posicionar de forma confusa, quando cita o instituto da autorização de serviço público no art. 21, XI e suprime tal instrumento do caput do art. 175. A priori, o jurista referido não entende 
que a Constituição Federal apresenta uma impropriedade, sobretudo, porque considera que o Poder Público, uma vez autorizado pela Carta Magna a delegar serviço público, poderá do modelo mais apropriado para fazê-lo, contanto que respeite os pressupostos indicados pelo Regime Jurídico de Direito Público.

Nessa perspectiva, é possível perceber que Estado vem lançando mão de modelos de exploração privada de serviços públicos que estão fora do rol indicado na CF/1988. Façamos, então, alguns apontamentos sobre cada modalidade de exploração privada de serviços públicos.

a. Autorização de serviço público. A terminologia "autorização" tem um significado híbrido, pois pode representar alvará discricionário da polícia administrativa ou instrumento precário que viabiliza o uso privado de bem público. Apesar de não ser referido universalmente pela dogmática jurídica, como instrumento de delegação de serviço público, não é possível deixar de referir à aplicação da autorização de serviço público na exploração de energia e serviços portuários, respectivamente nas leis 9.074/1995 e 12.815/2013.

b. A permissão de serviço público é uma modalidade de delegação de serviço público reconhecida por toda dogmática jurídica e disciplinada pela Lei 8987/1995. Com o advento dessa norma o instituto muda de natureza jurídica, deixando ser ato administrativo e passando a ser contrato. No plano jurídico o parágrafo único do artigo 40 da norma aludida parece sugerir um processo de equiparação quase integral entre concessão e permissão de serviço público, feita ressalva em relação à hipótese da permissionária ser pessoa física e se submeter o processo licitatório não vinculado à modalidade concorrência. Boa parte dos administrativistas brasileiro, como José dos Santos Carvalho Filho (2012, p.405) entendem que a encampação do serviço público permitido deve ser indenizada, apesar de Alexandre Santos Aragão (2013, p.689) sugerir que tal indenização só é devida se a permissão se revestir das características de concessão, inclusive com a hipótese de bens reversíveis ao final do contrato. No plano prático, a quase equiparação entre permissão e concessão de serviço público parece fundar um tempo de primazia para as concessões, já que as permissões têm fatia menor das delegações de serviço público. Quase sempre na radiodifusão de sons e exploração de transportes (em algumas capitais subsiste ainda a permissão para exploração de taxi).

c. A concessão de serviço público é o contrato pelo qual o Poder Público delega a particular (empresa privada ou consórcio de empresas) a execução de um serviço público após a realização de concorrência pública. Trata-se do instrumento clássico de exploração privada de serviços públicos que se materializa por meio de contrato de adesão, onde a remuneração da prestação é realizada quase sempre pelo particular mediante pagamento de tarifa. Nessa relação contratual destaca-se a rigidez do regime jurídico de direito público que confere ao particular o 
direito apenas a manutenção do equilíbrio econômico-financeiro do contrato. Cabe ao concedente selecionar a concessionária e dispor sobre o padrão de qualidade, quantidade e preço da oferta relativa aos serviços públicos. O concedente pode auditar não só a execução do serviço público, mas as práticas de gestão relacionadas à atuação da empresa privada. A encampação é um fenômeno cada vez mais raro, mais a ocupação temporária do serviço é permitida com a prova da inadimplência da concessionária. Recentemente, os embates mais frequentes na concessão de serviço público resultam da revisão da política tarifária, pois a revisão é um direito da concessionária que quase sempre rompe com a noção de modicidade imposta pela própria Lei $8987 / 1995$, por isso os governos têm recorrido muito aos subsídios pra tentar equilibrar esse conflito.

d. As parcerias público-privadas disciplinadas pela Lei 11.079/2004 apresentam um instrumento de exploração privada de serviços públicos que confere um novo fôlego as relações entre setor público e setor privado, pois a divisão dos riscos do empreendimento e os vários instrumentos que favorecem a credibilidade do parceiro público e a garantia do empreendimento provavelmente servem para estimular as relações entre o Público e Privado. De acordo com o professor Francisco Queiroz Bezerra Cavalcanti (2013, p.248), as PPP podem ser classificadas como um instrumento de fomento, sendo isso a sua natureza jurídica predominante. Por se tratar de um instituto de corte complexo a dogmática jurídica costuma reconhecer na PPP uma modalidade de concessão de serviço público que admite duas variáveis: a) concessão administrativa: contrato em que o parceiro privado presta um serviço em favor da Administração Pública, sendo remunerado diretamente por esta e; b) concessão patrocinada: contrato em que a concessionária serve diretamente a usuários de serviço público que se ocupam do seu financiamento, por meio de tarifa. Frequentemente a PPP é contrato que delega a exploração de um serviço público vinculado à conclusão de uma obra a cargo do particular, mas a Lei 11.079/2004 não estabelece que a obra é condição "sine qua mon" para a realização do contrato. De fato, os requisitos específicos são: I) prazo: não inferior a 5 nem superior a 35 anos de exploração, II) investimento global não inferior a 20 milhões de reais e III) a repartição dos riscos entre as partes com a fundação da sociedade de propósito específicas. Por fim não podemos deixar de mencionar que o regime jurídico de direito público cede um pouco nessa relação contratual marcada por uma relação mais paritária entre as partes. Por isso, é possível verificar na Lei 11.079/2004 muitos dispositivos que rompem com a noção de supremacia do Estado, nos moldes da Lei 8987/1995.

e. Parceria do Estado com o Terceiro Setor nos moldes das Leis 9.637/1998 e 9.790/1999. Voltamos a registrar que as Organizações Sociais - OS e as Organizações da 
Sociedade Civil de Interesse Público - OSCIP não são delegatórias de serviço público por natureza. Contudo, em algumas parcerias realizadas em Estados como São Paulo, Bahia e Pernambuco, os contratos de gestão e os termos de parceria podem remeter a exploração de serviço público, o que acontece, por exemplo, com a Organização Social que promovem serviços hospitalares atendendo pelo Sistema Único de Saúde- SUS. Nesse ponto o apontamento a delegação de serviço por meio de contratos de parceria com o Terceiro Setor decorre de uma alusão de Alexandre Santos Aragão (2013, 708-715) que ainda foi incorporada de forma mais abrangente na dogmática jurídica, mas que já encontra indicadores legislativos, haja vista que a Lei estadual 11.7432000 em Pernambuco admite expressamente a delegação de serviço público a entidades qualificadas como OS e OSCIP.

\section{Breve histórico sobre o Código de Defesa do Usuário de Serviço Público no Brasil}

Em meio as reformulações no direito administrativo brasileiro, entra em vigor a Lei 13.460/17 que dispõe sobre participação, proteção e defesa dos direitos do usuário dos serviços públicos da administração pública e regula o $\$ 3^{\circ}$ art. 37 e o inciso I do parágrafo único do art. 175 ambos da Constituição Brasileira, aquele dispositivo, por sua vez, foi incluído pela Emenda Constitucional $\mathrm{n}^{\circ} 19$ de 1998 a qual determinava o seguinte:

\footnotetext{
$\S 3^{\circ}$ A lei disciplinará as formas de participação do usuário na administração pública direta e indireta, regulando especialmente:

I - as reclamações relativas à prestação dos serviços públicos em geral, asseguradas a manutenção de serviços de atendimento ao usuário e a avaliação periódica, externa e interna, da qualidade dos serviços;

II - o acesso dos usuários a registros administrativos e a informações sobre atos de governo, observado o disposto no art. $5^{\circ}$, X e XXXIII;

III - a disciplina da representação contra o exercício negligente ou abusivo de cargo, emprego ou função na administração pública.
}

Conforme determinava o texto da Emenda Constitucional acima mencionada o Congresso Nacional, teria um prazo de cento e vinte dias para elaborar tal instrumento normativo, e como se observa foram necessários quase 20 anos para que a ordem constitucional efetivamente fosse concretizada. Trata-se de uma verdadeira omissão do Poder Legislativo que foi denunciada pela Ordem dos Advogados do Brasil conforme noticia Gabardo (2017): 
Em 2013 a Ordem dos Advogados do Brasil ingressou com uma Ação Direta de Inconstitucionalidade por Omissão solicitando que fosse determinada pelo Supremo Tribunal Federal a edição da lei e, enquanto não cumprida a determinação, a aplicação do Código de Defesa do Consumidor. Recebida como a ADO 24, a ação teve deferida a medida liminar pleiteada pelo Ministro Dias Toffoli em julho do mesmo ano. A decisão asseverou que o Congresso deveria cumprir a determinação constitucional no prazo de 120 dias. Desde então, a decisão judicial vinha sendo ignorada pelo Poder Legislativo, ainda que o assunto tenha se mantido em trâmite permanente desde 1999. Cabe salientar que a liminar/cautelar não autorizou a incidência provisória do CDC, embora já exista farta jurisprudência que o utiliza para serviços públicos (notadamente os remunerados mediante tarifa) e não sejam poucos os doutrinadores que defendem sua aplicação no setor público (no que for cabível).

Mesmo com toda a indesejada e recorrente procrastinação legislativa, enfim o instrumento normativo foi publicado e entrou em vigor e contribui para a regulamentação da relação entre usuário e prestador de serviços públicos, já vez que esse elo não poderia estar abarcado pelo Código de Defesa do Consumidor.

\section{Análise Dogmática e apontamento jurídicos sobre a Lei $13.460 / 2017^{8}$}

O Código de Defesa do Usuário do Serviço Público possui abrangência ampla e aplicase à administração pública direta e indireta da União, dos Estados, do Distrito Federal e dos Municípios.

Conforme exposto no início desse estudo, até então inexistia uma concepção legislativa de "serviço público", fazendo com que a doutrina elaborasse diversos conceitos. Pois bem, para o legislador serviço público é a atividade administrativa ou de prestação direta ou indireta de bens ou serviços à população, exercida por órgão ou entidade da administração pública e, o usuário desse serviço é toda pessoa física ou jurídica que se beneficia ou utiliza, efetiva ou potencialmente, de serviço público.

Estão abrangidos por essa lei desde o aluno de escola pública que possa ter problemas com seu uniforme escolar, a clínica médica que precise energia elétrica ininterrupto para a conservação refrigerada de medicamentos, o usuário do transporte coletivo público e até uma empresa privada que necessite de serviços de esgoto.

O Código do Usuário também traz alguns princípios que devem orientar a prestação de serviços públicos para os usuários, quais sejam: regularidade, continuidade, efetividade, segurança, atualidade, generalidade, transparência, cortesia. Como se observa a maioria deles são desdobramentos dos princípios constitucionais relativos a Administração Pública e

\footnotetext{
${ }^{8}$ Durante esse tópico todos os artigos legais referem-se a Lei 13.460/17.
} 
procuram estabelecer comandos aptos a incidir em situações fáticas específicas e concretas (CARVALHO, 2018).

Assim, os serviços públicos devem ser prestados com a maior qualidade possível e isso vai desde questões estruturais que garantam a acessibilidade aos estabelecimentos públicos até tratamento isonômico e cortês com a população usuária por parte dos servidores públicos. Além disso, regras especificas (proibições, horários de funcionamento, instruções normativas, etc) de determinados serviços públicos devem ser claras e expostas para que o usuário também se adeque ao ambiente público.

A informatização dos órgãos públicos é uma exigência da atualidade. Os recursos tecnológicos evitam o acumulo de filas, diminui o tempo de espera e resposta e garantem a acessibilidade dos serviços públicos em qualquer lugar. (LEVY, 1999)

Há expressão determinação de aplicação de soluções tecnológicas que visem a simplificar processos e procedimentos de atendimento ao usuário e a propiciar melhores condições para o compartilhamento das informações (art. 5, XIII), o acesso e obtenção de informações relativas à sua pessoa constantes de registros ou bancos de dados (art. 6, III) e também pode ser utilizada para a atuação integrada e sistêmica na expedição de atestados, certidões e documentos comprobatórios de regularidade (art. 6, V) e informações precisas e de fácil acesso nos locais de prestação do serviço via internet (art. 6, VI).

De fato, a gestão administrativa eficiente aumenta intercomunicação e dinamiza as operações dos órgãos com outros usuários e reduzem custos de tempo e recursos. E consoante apontam Nascimento, Freire e Dias, a tecnológica aplicada aos serviços públicos viabilizam o exercício da cidadania e reduz a distância entre a população e o Estado:

\begin{abstract}
A redução dos custos das tecnologias, em especial do computador, provocou sua disseminação e a consequente popularização, o que vem acarretando o aumento no número de usuários habilitados à operacionalização de suas funções básicas. (...) Nesse panorama, vários serviços públicos de atendimento ao cidadão estão sendo assegurados através do uso de tecnologias da informação. Ouvidorias, emissão de certidões, consulta a informações de interesse individual ou coletivo, acompanhamento de processos, postos "digitais" de atendimentos, emissão de GRU para pagamento de impostos etc. (2012, p. 175)
\end{abstract}

O Código estabelece ainda que o usuário não tem apenas direitos, mas também deveres, a relação entre o serviço/usuário e administração/administrados funciona como uma troca recíproca de prestações e contraprestações. A título de exemplo a lei estabelece atendimento por ordem de chegada, ressalvados casos de urgência e aqueles em que houver possibilidade de agendamento, asseguradas as prioridades legais às pessoas com deficiência, 
aos idosos, às gestantes, às lactantes e entre outros no teor do seu art. 5, III. Conforme o texto são deveres do usuário i) utilizar adequadamente os serviços, procedendo com urbanidade e boa-fé; ii) prestar as informações pertinentes ao serviço prestado quando solicitadas; iii) colaborar para a adequada prestação do serviço; e iv) preservar as condições dos bens públicos por meio dos quais lhe são prestados os serviços (art. 8).

A lei também estabelece diretrizes relativas as manifestações dos usuários que visam garantir direitos, permitindo que esses apresentem manifestações perante a administração pública acerca da prestação de serviços públicos. Criou-se um canal de comunicação direto entre o usuário e o órgão do Estado.

Há aqui, uma clara alusão ao direito de petição plasmado no art. $5^{\circ}$, XXXIV da Constituição, trata-se de instrumento jurídico-constitucional posto à disposição de qualquer interessado, com a explícita finalidade de viabilizar a defesa, perante as instituições estatais, de direitos revestidos tanto de natureza pessoal ou coletiva (BRASIL, 1995).

O procedimento administrativo relativo a manifestação que deverá observar os princípios da eficiência e da celeridade para a sua efetiva resolução se divide em algumas etapas, quais sejam: i) recepção da manifestação no canal de atendimento adequado; ii) emissão de comprovante de recebimento da manifestação; iii) análise e obtenção de informações, quando necessário; iv) decisão administrativa final; e v) ciência ao usuário tudo isso conforme o art. 12 .

O legislador também se preocupou em criar um órgão específico para acolhimento dos usuários, bem como para acompanhar, a prestação dos serviços e seu respectivo aperfeiçoamento. São as ouvidorias, que muito embora já existam em algumas das repartições públicas, agora são notadamente obrigatórias com funções fixas e estabelecidas. (Cf. GROTTI, 2017)

A prestação do serviço público também, nos termos da lei, passara por continua e periódica avaliação que terá participação do conselho de usuários e seus resultados serão integralmente publicados no sítio do órgão ou entidade, incluindo o ranking das entidades com maior incidência de reclamação dos usuários na periodicidade e servirá de subsídio para reorientar e ajustar os serviços prestados, em especial quanto ao cumprimento dos compromissos e dos padrões de qualidade de atendimento conforme estabelece o art. 23 e seguintes. 


\section{Conclusão}

Parece que um consenso na doutrina nacional e internacional remete a origem contemporânea do serviço público a França. O serviço público na França, portanto, é muito mais que um conceito jurídico, por se tratar de mito da história social francesa.

No direito brasileiro a prestação do serviço público e as competências para sua prestação possui base constitucional tamanha sua importância. De acordo com o texto constitucional incumbe ao poder público, na forma da lei, diretamente ou sob regime de concessão ou permissão, sempre através de licitação, a prestação de serviços públicos e muito embora não disponha de um conceito fixo, o legislador nos forneceu alguns subsídios que direcionam a área estipulada como própria dos serviços públicos.

Ao que tudo indica a legislação da proteção do usuário de serviço público tenta elevar a prestação desses serviços para outro patamar. No entanto, acreditamos que existirão dificuldades estruturais e culturais além de eventuais problemas de compatibilização entre normas que conforme Gabardo (2017) "tendem a ocorrer problemas de compatibilidade legislativa entre as normas específicas de cada órgão em cada Poder e esfera política da federação".

Todos os prestadores de serviço público da Administração Direta e Indireta e as concessionárias de serviço público deverão amoldar-se às novas diretrizes legais e viabilizar uma maior integração dos usuários à prestação dos serviços. A mudança tem prazo determinado para acontecer e as unidades da federação deverão se estruturar, para, assim, aplicarem na prática as novas disposições. A lei já está em vigor no âmbito da União, os estados, o Distrito Federal e os municípios com mais de quinhentos mil habitantes; em breve deverá também ser aplicada para Municípios entre cem mil e quinhentos mil habitantes e em breve para as cidades com menos de cem mil habitantes.

Por tudo e, portanto, caberá aos prestadores de serviço púbico preparar o seu pessoal e orientar os usuários para que ambos se adaptem as novas exigências legislativas, que nada mais são do que um reflexo cultural e uma exigência do atual modelo de gestão administrativa, que impõe uma população mais consciente e uma Estado mais eficiente. 


\section{Referências bibliográficas}

BRASIL, SUPREMO TRIBUNAL FEDERAL. ADI 1247 MC. Relator(a): Min. CELSO DE MELLO, Tribunal Pleno, julgado em 17/08/1995, DJ 08-09-1995 PP-28354 EMENT VOL01799-01 PP-00020).

; Direitos dos usuários. Enciclopédia jurídica da PUC-SP. Celso Fernandes Campilongo, Alvaro de Azevedo Gonzaga e André Luiz Freire (coords.). Tomo: Direito Administrativo e Constitucional. Vidal Serrano Nunes Jr., Maurício Zockun, Carolina Zancaner Zockun, André Luiz Freire (coord. de tomo). 1. ed. São Paulo: Pontifícia Universidade Católica de São Paulo, 2017. Disponível em: https://enciclopediajuridica. pucsp.br/verbete/74/edicao-1/direitos-dos-usuarios.

CARVALHO, Matheus. Manual de Direito Administrativo. 5 ed. Salvador: Editora Juspodivm, 2018.

CARVAlHO FILHO, José dos Santos. Manual de direito administrativo. 31. ed. São Paulo: Atlas, 2017

CARVALHO FILHO, José dos Santos. Regime jurídico dos termos de colaboração, termos de fomento e acordos de cooperação. In: MOTTA, Fabrício; MÂNICA, Fernando Borges; DI PIETRO, Maria Sylvia Zanella. Direito administrativo. 27. ed. São Paulo: Atlas, 2014.

DI PIETRO. Maria Sylvia Zanella. O princípio da segurança jurídica diante do princípio da legalidade. In: MARRARA, Thiago. (Org.). Princípios de direito administrativo: legalidade, segurança jurídica, impessoalidade, publicidade, motivação, eficiência, moralidade, razoabilidade, interesse público. São Paulo: Atlas, 2012.

GABARDO, Emerson. O novo Código de Defesa do Usuário de Serviço Público. Direito do Estado. Colunistas, Salvador, 27 jun. 2017, disponível em < http://www.direitodoestado. com.br/colunistas/emerson-gabardo/o-novo-codigo-de-defesa-do-usuario-do-servico-publicolei-13-460-17>. 
GAROFANO, Rafael Roque. Contratualidade administrativa: abrangência e complexidade do fenômeno contratual da Administração Pública. Rio de Janeiro: Lumen Juris, 2015.

GROTTI, Dinorá Adelaide Musetti. Evolução da teoria do serviço público. Enciclopédia jurídica da PUC-SP. Celso Fernandes Campilongo, Alvaro de Azevedo Gonzaga e André Luiz Freire (coords.). Tomo: Direito Administrativo e Constitucional. Vidal Serrano Nunes Jr., Maurício Zockun, Carolina Zancaner Zockun, André Luiz Freire (coord. de tomo). 1. ed. São Paulo: Pontifícia Universidade Católica de São Paulo, 2017. Disponível em: https://enciclopediajuridica.pucsp.br/verbete/40/edicao-1/evolucao-da-teoria-do-servicopublico

GUERRA FILHO, Willis Santiago. Filosofia do direito aplicada ao direito processual e à teoria da Constituição. 2 ed. Atlas, 2002.

LÉVY, Pierre Cibercultura. Tradução: Carlos Irineu da Costa. São Paulo: Editora 34, 1999.

NASCIMENTO, Stefanie Giulyane Vilela do; FREIRE, Gustavo Henrique de Araújo; DIAS, Guilherme Ataíde. A tecnologia da informação e a gestão pública. Gestão \& Aprendizagem, v. 01, p. 167-182, 2012.

OLIVEIRA, Gustavo Justino de. Contrato de gestão. São Paulo: Revista dos Tribunais, 2008.

MOREIRA NETO, Diogo de Figueiredo. Pactos administrativos: um enfoque pós-moderno. In: TEPEDINO, Gustavo; FACHIN, Luiz Edson. (Coords.). O direito e o tempo: embates jurídicos e utopias contemporâneas - estudos em homenagem ao Professor Ricardo Pereira Lira. Rio de janeiro: Renovar, 2008.

ROUSSEAU, Jean-Jacques. Do Contrato Social. Edição eletrônica: Ed Ridendo Castigat More, 2002.

SANTOS, Marcia Walquiria Batista dos. Cláusulas exorbitantes: da teoria à prática. In: DI PIETRO, Maria Sylvia Zanella; RIBEIRO, Carlos Vinícius Alves. (Coords.). Supremacia do interesse público e outros temas polêmicos. São Paulo: Atlas, 2010. 
SUNDFELD, Carlos Ari. Fundamentos do Direito Público. 5 ed. São Paulo: Malheiros, 2012.

SCHMIDT-ASSMANN, Eberhard. La teoía general del derecho administrativo como sistema. Barcelona, Marcial Pons, 2003. 


\title{
O CAMINHO DO ALARGAMENTO DAS DISPENSAS DE LICITAÇÃO NO \\ BRASIL: AS CONTRATAÇÕES DE PEQUENO VALOR E EMERGÊNCIA EM UMA ANÁLISE BRASIL-ESPANHA
}

\author{
Felipe Boselli \\ Universidade Federal de Santa Catarina \\ Carlos Araújo Leonetti \\ Universidade Federal de Santa Catarina
}

\section{Resumo}

Este artigo tem por objetivo analisar as dispensas de licitação no Brasil com ênfase na contratação de pequeno vulto e nos contratos emergenciais, fazendo um estudo comparado entre a legislação brasileira e espanhola. Os capítulos desenvolvem o panorama geral das contratações diretas no Brasil na atual Lei $n^{\circ}$ 8.666/93, o projeto de lei $n^{\circ} 6814 / 17$ e a ideia de ampliação do espectro de possibilidades das contratações de pequeno valor e emergenciais, além da análise do funcionamento dessas duas formas de contratação pública na nova lei espanhola, a Ley n ${ }^{\circ}$ 9/17.

Palavras-chave: contratos públicos, contratação direta, dispensa de licitação, pequeno valor, emergência.

\begin{abstract}
Resumen/Résumé
This article aims to analyze the waiver of bidding Brazil with emphasis on small value and emergency contracts, making a comparative study between the Brazilian and the Spanish legislation. The chapters provide an overview of no-bid contracts in Brazil in the current Law 8,666 / 93, the Bill $6814 / 17$ and the idea of expanding the spectrum of possibilities of small value and emergency hirings, as well as the analysis of the operation of these two forms of public procurement in the new Spanish law, 9/17.
\end{abstract}

Keywords/Palabras-claves/Mots-clés: public contracts, no-bid contracts, waiver of bidding, small value, emergency. 


\section{Introdução}

O presente artigo tem por problema de pesquisa como pode ser feita a compatibilização entre o mandamento constitucional de licitar e a eficiência administrativa com recorte metodológico sobre as contratações emergenciais e de pequeno valor.

A justificativa para o estudo está embasada no trâmite acelerado do Projeto de Lei $\mathrm{n}^{\circ} 6814 / 17$ que aumenta o espectro de possibilidades dessas duas dispensas de licitação, somado às estatísticas nacionais que apresentam um expressivo número de contratos administrativos realizados sem um processo licitatório prévio.

No Brasil tem-se um cenário atual em que cerca de $80 \%$ das contratações públicas realizadas pelo Portal de Compras Governamentais ocorreram por dispensa ou inexigibilidade de licitação, representando aproximadamente $40 \%$ de todo o volume de recursos gasto em contratos públicos.

Considerando que a Constituição de 1988 estabeleceu o dever de realização do processo licitatório, o Projeto de Lei que alarga as contratações sem licitação em um cenário que elas já correspondem a $80 \%$ dos processos merece uma análise mais detalhada.

Para responder a este problema utilizou-se do método dedutivo, por meio do direito comparado e da pesquisa documental direta, em especial a Lei $n^{\circ} 8.666 / 93$, o Projeto de Lei $n^{\circ} 6814 / 17$ e a Ley n ${ }^{\circ}$ 9/17 (lei espanhola de contratações públicas).

Assim este artigo foi dividido em três capítulos, sendo o primeiro uma análise geral da contratação direta no Brasil com o objetivo de explicar a atual divisão das contratações públicas sem licitação na Lei nº 8.666/93.

O segundo capítulo tem por tema central o alargamento das hipóteses de dispensa por pequeno valor no Projeto de Lei $n^{\circ} 6814 / 17$ e tem por objetivo analisar a possível nova sistemática de contratação direta no Brasil com ênfase nas contratações de pequeno valor e emergenciais.

O terceiro capítulo tem por objetivo central analisar as contratações diretas emergenciais e de pequeno vulto na legislação espanhola tendo por tema central a Ley 9/17 e seus artigos 118 a 120.

Por fim, a conclusão busca correlacionar os conceitos levantados no desenvolvimento do artigo, traçando um paralelo e buscando as possibilidades de convergência dos institutos espanhóis com a realidade brasileira da contratação pública. 


\section{O cenário da contratação direta no Brasil}

A Constituição brasileira de 1988 previu, dentre outras novidades, a obrigatoriedade de licitar as obras, serviços, compras e alienações como uma questão constitucional, demonstrando a importância dada a essa espécie de controle da Administração Pública.

O artigo 37, que rege a Administração Pública na Constituição, traz em seu inciso XXI a seguinte redação:

Art. 37. A administração pública direta e indireta de qualquer dos Poderes da União, dos Estados, do Distrito Federal e dos Municípios obedecerá aos princípios de legalidade, impessoalidade, moralidade, publicidade e eficiência e, também, ao seguinte:

$[\ldots]$

XXI - ressalvados os casos especificados na legislação, as obras, serviços, compras e alienações serão contratados mediante processo de licitação pública que assegure igualdade de condições a todos os concorrentes, com cláusulas que estabeleçam obrigações de pagamento, mantidas as condições efetivas da proposta, nos termos da lei, o qual somente permitirá as exigências de qualificação técnica e econômica indispensáveis à garantia do cumprimento das obrigações.

Assim, o Constituinte fez clara predileção pela licitação como requisito essencial à contratação pública. Isto significa afirmar que a CF88 oferece uma baliza interpretativa importante aos juristas. Esta baliza é a necessidade de se garantir a isonomia nas contratações públicas, como trata NIEBUHR (2015, p. 36):

A exigibilidade de licitação pública tem por causa o princípio da isonomia e, indiretamente, acaba por respaldar os princípios da impessoalidade e da moralidade administrativa. Portanto, antes de celebrar contratos, a Administração Pública, por regra, deve realizar licitação pública. Em paralelo a isso, há casos em que, legitimamente, o certame é afastado, delineando-se inexigibilidade e dispensa.

Não se pode supor que a Constituinte não tinha conhecimento sobre o que estava fazendo. É cediço que se tinha ciência sobre o que era um processo licitatório e seus trâmites burocráticos. Logo, não há dúvida que, ao determinar a realização de licitação prévia para contratação pública, a CF88 contrastou os princípios da eficiência ${ }^{1}$ e da isonomia e definiu que a isonomia era mais importante.

1Em 1987, quando da redação da CF/88, não se tinha ainda o princípio da eficiência posto como princípio constitucional explícito no artigo 37, o que só veio a ocorrer com a Emenda Constitucional no 19/98. Não obstante, a eficiência enquanto necessidade administrativa sempre existiu. O Estado sempre teve que buscar a eficiência, este é um conceito inerente ao gasto do dinheiro público. 
Esta análise de relevância a ser dada a cada um dos princípios foi previamente definida pelo texto constitucional. Este conceito é fundamental para que se afaste interpretações que busquem confrontar o dever de licitar e o princípio da eficiência como mecanismo de "fuga" do processo licitatório.

Alegar eficiência para afastar a licitação representa contratar diretamente em todos os casos, o que significaria assumir que a Assembleia Constituinte não sabia o que era licitação quando criou a regra de licitar.

Licitação é o processo administrativo por meio do qual a Administração, garantida a igualdade de condições dos interessados, busca a proposta mais vantajosa ao contrato de seu interesse.

Neste sentido, BANDEIRA DE MELLO (2003, p. 479) assim definiu o processo:

\begin{abstract}
Licitação - em suma síntese - é um certame que as entidades governamentais devem promover e no qual abrem disputa entre os interessados em com elas travar determinadas relações de conteúdo patrimonial, para escolher a proposta mais vantajosa às conveniências públicas. Estriba-se na idéia de competição, a ser travada isonomicamente entre os que preencham os atributos e aptidões necessários ao bom cumprimento das obrigações que se propõem assumir.
\end{abstract}

Ao exigir a realização de um processo licitatório, o texto constitucional, como primeiro requisito, já deixou claro que a licitação deve assegurar a igualdade de condição a todos os concorrentes, sendo ladeado este conceito pelo art. $3^{\circ}$ da Lei $n^{\circ} 8.666 / 93$, que estabelece que o processo licitatório se destina a garantir o princípio constitucional da isonomia.

A isonomia é a razão de ser do processo licitatório. Houve, em nosso avanço como nação republicana, uma justa predileção por um sistema que garantisse a igualdade de condições a todos os interessados, afastando, ainda que em tese ${ }^{2}$, os interesses escusos, as preferências arbitrárias e o patrimonialismo.

A exigência de um processo licitatório está para a contratação pública assim como o concurso público está para a contratação de servidores públicos, aqui empregando o termo em sentido lato e abrangente. Ainda que se possa tecer diversas críticas pontuais a esses sistemas,

2Não é objetivo do presente trabalho discutir a eficiência do atual modelo licitatório (ou modelos, quando considerados os diversos diplomas normativos que regem diferentes sistemas licitatórios - LGL, Pregão, Concessões, RDC ou Estatais). Há diversas obras que discutem a eficiência de questões legislativas pontuais. Não obstante estes apontamentos, nos parece inegável que a exigência de um processo isonômico de seleção antecedendo a contratação pública é um importante avanço em um Estado que se pretenda minimamente republicano. 
ambos presentes na CF88, não é possível afirmar que seria mais adequado um sistema de contratação, quer seja de empresas, quer seja de pessoal, que não observasse garantias fundamentais mínimas.

Não se está aqui a afirmar que o sistema licitatório é imune a críticas. Mas é fundamental destacar, para que seja possível a plena compreensão do presente trabalho, que muitas das críticas que se faz à licitação não possuem fundamento jurídico. Neste sentido, sem dúvida, a principal delas, é o estigma do processo licitatório de contratar produtos de péssima qualidade, em razão do critério mais comum nas licitações que é o critério do menor preço.

Este estigma de nossos processos licitatórios decorre, fundamentalmente, de uma interpretação rasa e equivocada acerca do que seria o critério do menor preço.

Os tipos de licitação previstos no artigo 45 da LGL têm por objetivo conferir ao processo um formato de julgamento objetivo de cada uma das propostas. Neste sentido, vem seu $\S 1^{\circ}$, inciso I, que aponta como critério o menor preço e o explica:

\footnotetext{
Art. 45. O julgamento das propostas será objetivo, devendo a Comissão de licitação ou o responsável pelo convite realizá-lo em conformidade com os tipos de licitação, os critérios previamente estabelecidos no ato convocatório e de acordo com os fatores exclusivamente nele referidos, de maneira a possibilitar sua aferição pelos licitantes e pelos órgãos de controle.

$\S 1^{\circ}$ Para os efeitos deste artigo, constituem tipos de licitação, exceto na modalidade concurso:

I - a de menor preço - quando o critério de seleção da proposta mais vantajosa para a Administração determinar que será vencedor o licitante que apresentar a proposta de acordo com as especificações do edital ou convite e ofertar o menor preço;
}

Nota-se que o critério de seleção do menor preço não é e nem poderia ser atribuído de forma aleatória, entre todos os fornecedores do mercado. O critério determina a seleção da proposta com o menor preço dentre aquelas que estiverem de acordo com as especificações do edital ou convite.

A ideia normativa está correta. Se a Administração definiu que o necessário para atender às suas necessidades é um veículo 1.0, isto significa que qualquer oferta que contenha vantagem além dessa demanda da Administração é mero luxo. Se o Estado necessita de um veículo 1.0, é imperioso que se adquira o veículo mais barato no mercado que atenda às essas especificações.

A crítica à baixa qualidade dos produtos licitados decorre, portanto, não do critério menor preço, mas sim da especificação inadequada de produtos ou serviços, que acabam 
fazendo com que a Administração Pública contrate produtos que não atendem às suas necessidades.

Se o contrato não atende à demanda da Administração, isto significa, em regra, que as necessidades não foram bem definidas no instrumento convocatório ou que a execução do contrato não foi fiscalizada de forma efetiva. Não há como considerar válida a crítica que simplesmente lança sobre os ombros do processo licitatório as falhas de planejamento da Administração Pública.

A contratação por meio de licitação não significa o produto mais barato em detrimento de uma necessária qualidade. É perfeitamente possível realizar processo licitatório para contratar produtos de alta qualidade e, muitas vezes, de altos valores. Basta que o processo seja suficientemente detalhado e justificada as reais necessidades da Administração, para que se evidencie que não se está diante do puro desperdício de recursos públicos.

MENDES e MOREIRA (2016, p. 92) alertam sobre a aplicação de recursos públicos de forma eficiente com a necessidade de se considerar o binômio do custo-benefício. Não necessariamente pagar pouco significa ser eficiente. Para os autores, o preço não poderia considerar os benefícios almejados, mas sim estes que devem condicionar o preço.

As contratações públicas têm por objetivo fundamental atender ao interesse público, o Estado não pode contratar mal, deve planejar suas contratações e, com isso, satisfazer às suas demandas e atender à população.

Desta forma, tem-se a regra constitucional sendo a obrigatoriedade de licitar, sendo as contratações diretas sua exceção. Ocorre que os números não comprovam tal condição.

O Portal de Transparência do Governo Federal, em seu Painel de Compras ${ }^{3}$, que permite ao usuário filtrar a quantidade de contratações e o valor desembolsado em cada uma delas, por modalidade, naqueles processos registrados no Portal Compras Governamentais do Governo Federal.

Os dados aqui apontados referem-se apenas às contratações do Portal Compras Governamentais, que embarca boa parte da esfera federal e alguns municípios, trazendo informações de 2012 até novembro de 2017:

3Disponível em: https://www.comprasgovernamentais.gov.br/index.php/painel-de-compras-de-governo. Acesso em 19 nov. 2017. 


\begin{tabular}{|l|l|l|l|l|}
\hline \multicolumn{1}{|c|}{ MODALIDADE } & \multicolumn{1}{c|}{ QUANTIDADE } & \multicolumn{1}{c|}{ VALOR } & \multicolumn{1}{c|}{$\%$} \\
\hline Tomada de Preços & 3.476 & $0,5 \%$ & $\mathrm{R} \$ 1.283 .629 .214,62$ & $0,5 \%$ \\
\hline Concorrência & 3.453 & $0,5 \%$ & $\mathrm{R} \$ 23.050 .474 .817,28$ & $8,6 \%$ \\
\hline Convite & 905 & $0,1 \%$ & $\mathrm{R} \$ 46.753 .566,71$ & $0,0 \%$ \\
\hline Concorrência Internacional & 150 & $0,0 \%$ & $\mathrm{R} \$ 297.551 .436,23$ & $0,1 \%$ \\
\hline Pregão & 122.327 & $18,9 \%$ & $\mathrm{R} \$ 140.403 .213 .777,94$ & $52,5 \%$ \\
\hline Dispensa de Licitação & 423.379 & $65,4 \%$ & $\mathrm{R} \$ 50.326 .073 .545,34$ & $18,8 \%$ \\
\hline Inexigibilidade de Licitação & 93.348 & $14,4 \%$ & $\mathrm{R} \$ 51.846 .485 .402,08$ & $19,4 \%$ \\
\hline Concurso & 87 & $0,0 \%$ & $\mathrm{R} \$ 27.002 .286,81$ & $0,0 \%$ \\
\hline TOTAL & 647.125 & & $\mathrm{R} \$ 267.281 .184 .047,01$ & \\
\hline
\end{tabular}

Somando os itens de dispensa e inexigibilidade de licitação, é possível perceber que, dos dados colhidos pelo portal Compras Governamentais, 79,8\% (setenta e nove vírgula oito por cento) das contratações registradas foram feitas por dispensa ou inexigibilidade de licitação, representando um volume financeiro contratado de mais de cem bilhões de reais no período, $38,2 \%$ (trinta e oito vírgula dois por cento) do total contratado em valor.

Esta estatística, dentre outras que podem ser consultadas, gera uma séria constatação acerca da regra de licitação albergada pela Constituição Federal de 1988.

Ora, se a regra é licitar e, portanto, a dispensa e inexigibilidade são exceções, a quantidade de processos contratuais que não são precedidos de licitação é um número que não condiz com o texto constitucional.

Aparentemente, essa disparidade entre a regra da licitação estabelecida pela Constituição Federal e a prática dos contratos administrativos poderia decorrer do nítido acréscimo que vem ocorrendo na quantidade de hipóteses de dispensa de licitação, como apontado neste quadro: 


\begin{tabular}{|c|c|c|}
\hline DIPLOMA LEGAL & DISPOSITIVO & NÚMERO DE HIPÓTESES \\
\hline $\begin{array}{c}\text { Código de Contabilidade/1922 } \\
4 \text { hipóteses positivadas }\end{array}$ & art. 246 & 4 - Dispensa \\
\hline $\begin{array}{c}\text { Decreto-lei 200/67 } \\
9 \text { hipóteses positivadas }\end{array}$ & art. 126 & 9 - Dispensa \\
\hline $\begin{array}{c}\text { Decreto } 73.140 / 73 \\
8 \text { hipóteses positivadas }\end{array}$ & art. $8^{\circ}$ & 8 - Dispensa \\
\hline Decreto-lei 2.300/86 & art. 22 & 11 - Dispensa \\
\hline 16 hipóteses positivadas & art. 23 & 5 - Inexigibilidade \\
\hline \multirow{3}{*}{$\begin{array}{c}\text { Lei 8.666/93 original } \\
33 \text { hipóteses positivadas }\end{array}$} & art. 17 & 10 - dispensada \\
\hline & art. 24 & 15 - Dispensa \\
\hline & art. 25 & 3 - Inexigibilidade \\
\hline \multirow{3}{*}{$\begin{array}{l}\text { Lei } 8.666 / 93 \text { atual } \\
\text { hipóteses positivadas }\end{array}$} & art. 17 & 15 - dispensada \\
\hline & art. 24 & 35 - Dispensa \\
\hline & art. 25 & 3 - Inexigibilidade \\
\hline
\end{tabular}

Este crescimento normativo das hipóteses de contratação direta está prestes a se acentuar, com a iminente aprovação do PL 6814/17 (PLS 559/2013), em trâmite na Câmara dos Deputados.

\section{O alargamento da dispensa de licitação no projeto de Lei $n^{0} 6814 / 17$}

Das hipóteses de dispensa de licitação, dois casos extremamente utilizados são os contratos de pequeno valor (incisos I e II) e os contratos de emergência (inciso IV).

Estas duas hipóteses de dispensa receberam especial atenção do novo legislador. As hipóteses de pequeno valor (incisos I e II) com a ampliação de sua margem; e os contratos de emergência com a ampliação do seu prazo: 


\begin{tabular}{|c|c|}
\hline LEI No 8.666/93 & PROJETO DE LEI N 6814/17 \\
\hline Art. 24. É dispen & o: \\
\hline $\begin{array}{l}\text { I - para obras e serviços de engenharia de valor até } \\
{[\mathrm{R} \$ 15.000,00]^{4} \text {, desde que não se refiram a }} \\
\text { parcelas de uma mesma obra ou serviço ou ainda } \\
\text { para obras e serviços da mesma natureza e no } \\
\text { mesmo local que possam ser realizadas conjunta e } \\
\text { concomitantemente; }\end{array}$ & $\begin{array}{l}\text { I - para contratação que envolva valores inferiores a } \\
\text { R\$ 60.000,00 (sessenta mil reais), no caso de obras } \\
\text { e serviços de engenharia, desde que a modalidade } \\
\text { convite não possa ser empregada sem prejuízo aos } \\
\text { objetivos da contratação; }\end{array}$ \\
\hline $\begin{array}{l}\text { II - para outros serviços e compras de valor até [R\$ } \\
8.000,00] \text { e para alienações, nos casos previstos } \\
\text { nesta Lei, desde que não se refiram a parcelas de um } \\
\text { mesmo serviço, compra ou alienação de maior vulto } \\
\text { que possa ser realizada de uma só vez; }\end{array}$ & $\begin{array}{l}\text { II - para contratação que envolva valores inferiores } \\
\text { a R } \$ 15.000,00 \text { (quinze mil reais), no caso de outros } \\
\text { serviços e compras, desde que a modalidade convite } \\
\text { não possa ser empregada sem prejuízo aos objetivos } \\
\text { da contratação; }\end{array}$ \\
\hline $\begin{array}{l}\text { IV - nos casos de emergência ou de calamidade } \\
\text { pública, quando caracterizada urgência de } \\
\text { atendimento de situação que possa ocasionar } \\
\text { prejuízo ou comprometer a segurança de pessoas, } \\
\text { obras, serviços, equipamentos e outros bens, } \\
\text { públicos ou particulares, e somente para os bens } \\
\text { necessários ao atendimento da situação emergencial } \\
\text { ou calamitosa e para as parcelas de obras e serviços } \\
\text { que possam ser concluídas no prazo máximo de } 180 \\
\text { (cento e oitenta) dias consecutivos e ininterruptos, } \\
\text { contados da ocorrência da emergência ou } \\
\text { calamidade, vedada a prorrogação dos respectivos } \\
\text { contratos; }\end{array}$ & $\begin{array}{l}\text { VIII - nos casos de emergência ou de calamidade } \\
\text { pública, quando caracterizada urgência de } \\
\text { atendimento de situação que possa ocasionar } \\
\text { prejuízo ou comprometer a segurança de pessoas, } \\
\text { obras, serviços, equipamentos e outros bens, } \\
\text { públicos ou particulares, e somente para os bens } \\
\text { necessários ao atendimento da situação emergencial } \\
\text { ou calamitosa e para as parcelas de obras e serviços } \\
\text { que possam ser concluídas no prazo máximo de } 360 \\
\text { (trezentos e sessenta) dias consecutivos e } \\
\text { ininterruptos contados da ocorrência da emergência } \\
\text { ou da calamidade, vedada a prorrogação dos } \\
\text { respectivos contratos; }\end{array}$ \\
\hline
\end{tabular}

Os incisos I e II do projeto de lei pretendem inovar ao inserir novo fator de discrímen subjetivo, ao inserir a condição de "desde que a modalidade convite não possa ser empregada sem prejuízo aos objetivos da contratação”. A nosso sentir, tal condição altamente subjetiva é um convite para o conflito hermenêutico e para possíveis decisões conflitantes no âmbito dos órgãos de controle. Não obstante, este tema não será objeto do presente artigo.

O presente artigo se restringirá ao estudo de dois acréscimos: a) o aumento do valor nos contratos de pequena monta; e b) o aumento do prazo nos contratos emergenciais. 


\section{a. Os contratos de pequeno valor}

Primeiramente, cumpre destacar que, considerando que o texto ora debatido ainda está em discussão, havendo, inclusive, aqueles que defendam um acréscimo, ainda maior, nas hipóteses de contratação direta por pequeno valor.

Além da proposta de aumento em trâmite na Câmara dos Deputados, há quem defenda a atualização dos valores ${ }^{5}$, levando os limites de dispensa de licitação a patamares ainda mais elevados, calculado a partir do IPCA desde a definição dos valores na Lei no 8.666/93 até hoje, como foi facultado no seu artigo 120:

Art. 120. Os valores fixados por esta Lei poderão ser anualmente revistos pelo Poder Executivo Federal, que os fará publicar no Diário Oficial da União, observando como limite superior a variação geral dos preços do mercado, no período.

Considerando que o valor foi alterado para reais em maio de 1998, se atualizado pelo IPCA até março de 2018 representaria um acréscimo de 239\% (BRASIL, 2018), passando o valor de $\mathrm{R} \$ 8.000,00$ para $\mathrm{R} \$ 27.134,19$ no caso das compras e serviços e o valor de $\mathrm{R} \$$ $15.000,00$ para $\mathrm{R} \$ 50.876,79$ no caso de obras e serviços de engenharia.

Exemplo prático desse acréscimo no valor das dispensas de licitação deu-se no Estado do Mato Grosso que, por intermédio da Lei Estadual n ${ }^{0} 10.534 / 17$, atualizou, pelo IGPM ${ }^{6}$, os valores previstos na Lei $n^{\circ} 8.666 / 93$ e, consequentemente, elevou os valores de dispensa de licitação $\mathrm{R}$ \$ 8.000,00 para R $34.379,33$ no caso das compras e serviços e o valor de R\$ $15.000,00$ para $\mathrm{R} \$ 64.461,25$ no caso de obras e serviços de engenharia.

Outro caso de aumento expressivo nos valores das contratações diretas deu-se na Lei $\mathrm{n}^{\circ} 13.303 / 16$, conhecida como Lei das Estatais, que traz o estatuto jurídico da empresa pública, sociedade de econômica mista e de suas subsidiárias, no âmbito da União, Estados, Distrito Federal e Municípios. Dispõe o seu artigo 29:

\footnotetext{
${ }^{5} \mathrm{O}$ instituto Negócios Públicos (2014) formulou estudo em que concluiu que o custo médio de realização de um processo licitatório seria de $\mathrm{R} \$ 12.849,00$. Este custo embasa a discussão acerca do baixo valor indexado à dispensa nas contratações de pequeno vulto.

${ }^{6}$ A diferença entre o valor da lei mato-grossense e o cálculo anteriormente exposto dá-se pelo índice utilizado (IGPM ao invés do IPCA) e o período que foi de maio de 1998 a março de 2016, conforme exposto no art. $1^{\circ}$ da Lei Estadual (MT) n ${ }^{\circ} 10.534 / 17$.
} 
Art. 29. É dispensável a realização de licitação por empresas públicas e sociedades de economia mista:

I - para obras e servicos de engenharia de valor até $\mathbf{R} \$ \mathbf{1 0 0 . 0 0 0 , 0 0}$ (cem mil reais), desde que não se refiram a parcelas de uma mesma obra ou serviço ou ainda a obras e serviços de mesma natureza e no mesmo local que possam ser realizadas conjunta e concomitantemente;

II - para outros servicos e compras de valor até $\mathbf{R} \$ \mathbf{5 0 . 0 0 0 , 0 0}$ (cinquenta mil reais) e para alienações, nos casos previstos nesta Lei, desde que não se refiram a parcelas de um mesmo serviço, compra ou alienação de maior vulto que possa ser realizado de uma só vez; (grifou-se)

Sob o argumento da necessidade de se flexibilizar as contratações públicas das empresas estatais, conferindo-lhes maior dinamicidade e capacidade de atuação no mercado, os valores admitidos às dispensas de pequeno valor foi majorado em mais de $500 \%$ com relação à Lei ${ }^{\circ} 8.666 / 93$.

Este movimento pelo acréscimo no valor dos contratos administrativos passíveis de dispensa de licitação obviamente majorará significativamente os percentuais atuais de contratação direta que já não são baixos, como visto anteriormente, no Brasil a contratação direta que deveria ser exceção, de acordo com o texto constitucional, representa, no Portal de Compras Governamentais, 79,8\% (setenta e nove vírgula oito por cento) das contratações, com um volume financeiro contratado de mais de cem bilhões de reais no período, 38,2\% (trinta e oito vírgula dois por cento) do total contratado em valor.

Ao ampliar os valores dos contratos administrativos de pequeno valor, o legislador deixou de avançar sobretudo no que tange às possibilidades de automatização desses procedimentos, dando-lhes mais publicidade e dinamicidade.

Sobre o tema, merece destaque a legislação do Estado de São Paulo, com o Decreto Estadual $n^{\circ}$ 59.104/13, que aprova o regulamento do Sistema Bolsa Eletrônica de Compras BEC para a realização das dispensas de licitação de forma eletrônica. Bem como o Município de São Paulo que regulamentou a realização de dispensas por meio do mesmo sistema BEC pelo Decreto Municipal no 54.102/137.

\footnotetext{
${ }^{7}$ BENTO (2016, p. 5) destaca as vantagens de se utilizar o sistema da Bolsa Eletrônica de Compras de São Paulo - BES/SP para as contratações de pequeno que possam ser feitas por dispensa de licitação como a transparência dos procedimentos, a redução dos custos processuais, a economicidade dos processos e a agilidade na contratação.
} 


\section{b. Os contratos emergenciais}

Seguindo o mesmo movimento das contratações de pequeno valor, o Projeto de Lei $\mathrm{n}^{\mathrm{o}}$ 6814/17 também busca inovar nas contratações emergenciais, ampliando o prazo de 180 (cento e oitenta) dias para 360 (trezentos e sessenta dias).

Assim como nas contratações de pequeno valor, o acréscimo no prazo dos contratos emergenciais, sem dúvida, robustecerá as contratações diretas, possibilitando a contratação por emergência muito mais casos.

A Constituição, ao criar a possibilidade de o legislador infraconstitucional estabelecer ressalvas à obrigatoriedade do processo licitatório criou uma norma de caráter dúplice.

De um lado, estabelece hipótese de controle da atividade administrativa que, ao realizar suas contratações, somente poderá contratar sem processo licitatório se houver autorização legal para tal ato.

De outro lado, implicitamente, a norma resguarda matéria de controle de constitucional no que tange à possibilidade de criação de normas dispensadoras da licitação.

Em sendo o processo licitatório a regra constitucional, não poderia o legislador criar normas dispensadoras que não detivessem uma justificativa das razões que fundamentam a autorização legal para não fazer a contratação por meio de licitação.

Neste cenário, estaria em tese justificada a contratação direta quando se tratar de situação emergencial cujo prazo de execução é inferior a 180 dias contados da data da emergência.

Isto porque, quando da elaboração da Lei no 8.666/93, a modalidade de licitação para contratos mais relevantes era a Concorrência, o que significava dizer que um processo licitatório teria, no mínimo, os seguintes prazos:

\begin{tabular}{|c|c|}
\hline Prazo de Publicação do Edital & 30 dias \\
\hline Recurso na fase de habilitação & 5 dias úteis (7 dias) \\
\hline Comunicação do recurso aos demais & sem prazo legal \\
\hline Impugnação ao Recurso & 5 dias úteis (7 dias) \\
\hline Revisão da decisão pela Comissão & 5 dias úteis (7 dias) \\
\hline Decisão da Autoridade Superior & 5 dias úteis (7 dias) \\
\hline Designação abertura das propostas & sem prazo legal \\
\hline Recurso na fase de classificação & 5 dias úteis (7 dias) \\
\hline Comunicação do recurso aos demais & sem prazo legal \\
\hline Impugnação ao Recurso & 5 dias úteis (7 dias) \\
\hline Revisão da decisão pela Comissão & 5 dias úteis (7 dias) \\
\hline Decisão da Autoridade Superior & 5 dias úteis (7 dias) \\
\hline
\end{tabular}


Significa afirmar que, mesmo na hipótese de a Administração gastar um único dia para cada ato que não há prazo legal, já seriam 90 dias para executar a fase externa de uma concorrência. Isto se a Administração cumprisse rigorosamente seus prazos de julgamento de recursos, se não houvesse nenhuma impugnação ao edital e nem decisão judicial ou dos órgãos de controle que suspendesse o processo licitatório.

Ainda que este prazo possa variar para mais ou para menos, por exemplo, com um prazo maior para tomada de decisões ou agendamento das sessões públicas, ou, no outro sentido, com a desistência de recursos administrativos, este prazo de aproximadamente 90 dias deve servir como parâmetro mínimo de segurança para a realização de um processo licitatório ágil.

Neste sentido, o estabelecimento de um prazo de 180 dias para a execução de um contrato, entre a data da emergência e sua conclusão, detinha um pressuposto lógico de razoabilidade, em que se buscava acelerar algo que seria rápido (executado em menos de 180 dias) e que seria amplamente retardado com a realização de um processo licitatório, podendo comprometer, significativamente, o interesse público pela morosidade da prestação estatal.

Importante destacar que, desde o advento da Lei $n^{\circ} 8.666 / 93$, o prazo dos processos licitatório diminuiu, em razão da implementação da modalidade pregão. Nesta modalidade, trazida pela Lei $\mathrm{n}^{\mathrm{o}} 10.520 / 02$ as etapas foram invertidas, os prazos foram reduzidos e a fase recursal foi unificada, representando importante redução de prazo.

Montando tabela similar à exposta anteriormente, seriam apresentados os seguintes prazos para a modalidade pregão:

\begin{tabular}{|c|c|}
\hline Prazo de Publicação do Edital & 8 dias úteis \\
\hline Recurso unificado & 3 dias úteis \\
\hline Comunicação do recurso aos demais & Automaticamente na sessão pública \\
\hline Impugnação ao Recurso & 3 dias úteis \\
\hline Revisão da decisão pelo Pregoeiro & 3 dias úteis \\
\hline Decisão da Autoridade Competente & 3 dias úteis \\
\hline
\end{tabular}

O processo licitatório na modalidade pregão tem, como prazos mínimos, utilizando-se da mesma metodologia adotada para a concorrência, um prazo de 21 dias úteis, ou seja, aproximadamente 30 dias, representando um terço do prazo necessário a uma Concorrência. 
Neste cenário, o impacto na realização do processo licitatório ${ }^{8}$ foi drasticamente reduzido, o que deveria, em tese, implicar em uma redução no prazo admitido por lei para a execução dos contratos emergenciais.

Não obstante, na contramão dessa redução do prazo licitatório, o Projeto de Lei $\mathrm{n}^{\circ}$ 6814/17 prevê o aumento do prazo de 180 dias para 360 dias para a execução dos contratos emergenciais.

\section{O modelo de contratação espanhol}

As mudanças no processo licitatório devem ser precedidas de estudo e compreensão ampla de seus impactos. Estudo da $\mathrm{OCDE}^{9}$ mostra que, em média, as contratações públicas representam 12\% do Produto Interno Bruto, dentre os países que fazem parte daquela organização. O número é absolutamente expressivo e provoca a inquietação e a necessidade de debruçar-se sobre a matéria.

Quando contrastado com a estatística de contratações direta anteriormente apresentadas, em que quase quarenta por cento do gasto em contratos administrativos é feito por dispensa ou inexigibilidade de licitação, o que se está a discutir aqui é algo, em um cálculo absolutamente estimativo, de cerca de 76 bilhões de reais ${ }^{10}$ e como é gasto esse recurso.

Neste sentido, é importante analisar como se dão as contratações públicas em outros países, sendo o modelo espanhol o escolhido para fazer a análise no presente artigo.

Para isto, será analisado o texto da nova Lei de Contratos del Sector Público, Ley 9/2017, dois institutos de contratação pública espanhóis: a) as contratações de pequeno valor; e b) os contratos emergenciais.

\section{a. As contratações de pequeno valor}

A legislação espanhola prevê, no artigo 118 da Ley 9/2017 ${ }^{11}$, o expediente de contratação de contratos menores, com as seguintes definições:

\footnotetext{
${ }^{8}$ Importante destacar que tanto na realização de um processo licitatório tradicional quanto no pregão ou na contratação emergencial será necessária a fase interna do processo licitatório, ou seja, a realização de pesquisa de preços, verificação de dotação orçamentária, aprovação da Autoridade Superior e pareceres jurídicos e a elaboração do termo de referência ou projeto básico. Desta forma, a única variável entre a dispensa por emergência e a realização de licitação é a existência, ou não, da fase externa.

9 Disponível em: http://www.oecd.org/governance/public-procurement/. Acesso em 19 nov. 2017.

${ }^{10} \mathrm{O}$ PIB do Brasil em 2017 foi de 1,595 trilhão de reais. Se as contratações públicas representam 12\% desse valor, resulta em um montante de 191,4 bilhões de reais. Sobre este valor foi aplicada a estimativa de $40 \%$ de contratação direta, em um total de 76,56 bilhões de reais.

${ }^{11}$ Artículo 118. Expediente de contratación en contratos menores.
} 
Nota-se que a legislação espanhola adota estrutura similar à brasileira no que tange à contratação de pequenos valores, por meio de um processo de contratação sem a realização de licitação.

Sobre este ponto, dois aspectos merecem destaque.

O primeiro é a estrutura legal desenvolvida para explicar o funcionamento dos contratos de menor valor, dando ao gestor público maior segurando acerca do que pode ser feito. No Brasil, a legislação sobre contratos de pequena monta resume-se à simples citação de que poderá ser feita por dispensa, delegando, na prática, à doutrina e à jurisprudência a regulamentação de suas especificidades.

O segundo ponto é que, na contramão do que pretende a legislação brasileira, os espanhóis, desde sua última norma de contratação pública, o Real Decreto Legislativo 3/2011, reduziu a capacidade de compra por contratos menores. Assim era a redação do artigo 138.3 daquela norma:

3. Los contratos menores podrán adjudicarse directamente a cualquier empresario con capacidad de obrar y que cuente con la habilitación profesional necesaria para realizar la prestación, cumpliendo con las normas establecidas en el artículo 111.

Se consideran contratos menores los contratos de importe inferior a 50.000 euros, cuando se trate de contratos de obras, o a 18.000 euros, cuando se trate de otros contratos, sin perjuicio de lo dispuesto en el artículo 206 en relación con las obras, servicios y suministros centralizados en el ámbito estatal. (grifou-se)

Tem-se, portanto a seguinte redução:

\begin{tabular}{|l|c|c|}
\hline & Real Decreto Leg 3/2011 & Ley 9/2017 \\
\hline Obras & $50.000 €$ & $40.000 €$ \\
\hline Compras e serviços & $18.000 €$ & $15.000 €$ \\
\hline
\end{tabular}

\footnotetext{
1. Se consideran contratos menores los contratos de valor estimado inferior a 40.000 euros, cuando se trate de contratos de obras, o a 15.000 euros, cuando se trate de contratos de suministro o de servicios, sin perjuicio de lo dispuesto en el artículo 229 en relación con las obras, servicios y suministros centralizados en el ámbito estatal. En los contratos menores la tramitación del expediente exigirá el informe del órgano de contratación motivando la necesidad del contrato. Asimismo se requerirá la aprobación del gasto y la incorporación al mismo de la factura correspondiente, que deberá reunir los requisitos que las normas de desarrollo de esta Ley establezcan.

2. En el contrato menor de obras, deberá añadirse, además, el presupuesto de las obras, sin perjuicio de que deba existir el correspondiente proyecto cuando normas específicas así lo requieran. Deberá igualmente solicitarse el informe de las oficinas o unidades de supervisión a que se refiere el artículo 235 cuando el trabajo afecte a la estabilidad, seguridad o estanqueidad de la obra.

3. En el expediente se justificará que no se está alterando el objeto del contrato para evitar la aplicación de las reglas generales de contratación, y que el contratista no ha suscrito más contratos menores que individual o conjuntamente superen la cifra que consta en el apartado primero de este artículo. El órgano de contratación comprobará el cumplimiento de dicha regla. Quedan excluidos los supuestos encuadrados en el artículo 168.a).2. ${ }^{\circ}$ 4. Los contratos menores se publicarán en la forma prevista en el artículo 63.4.
} 
Cabe ressaltar que o IPC (Indice de Precios de Consumo) espanhol de novembro de 2011 a novembro de 2017 foi de 4,9\% ${ }^{12}$, ou seja, a redução feita pela Ley 9/2017 foi da ordem de $30 \%$, quando somada a redução nominal à inflação acumulada no período.

Mas como compatibilizar a dispensa de licitação de pequeno valor com o custo real de elaboração de um processo licitatório? Como é possível atender ao mandamento constitucional de licitar (ainda que existente apenas no Brasil) com a eficiência necessária aos serviços públicos.

A nova Ley 9/2017 também trouxe esta preocupação e a respondeu. Para tal, a norma inovou ao trazer dois novos institutos ao ordenamento jurídico daquele país, o Procedimiento Abierto Simplificado (PAS), previsto no artigo 159, e o Procedimiento Abierto Super Simplificado (PASS), regulado no artigo 159.6.

Sem entrar no mérito de cada um dos procedimentos, para não fugir do tema central do presente artigo, que é a contratação direta, a legislação espanhola avançou, reduzindo a contratação pública sem licitação ao mesmo tempo em que cria um procedimento mais simples e, portanto, com menor custo, para contratos de pequeno valor que superem o limite mínimo de contratação sem licitação.

\section{b. Os contratos emergenciais}

Outra forma de contratação direta muito usual no Brasil e também presente na legislação espanhola são os contratos emergenciais, ou seja, aqueles nos quais o tempo de realização do processo licitatório pode comprometer a satisfação do interesse público.

Nesta espécie de contratação direta a legislação espanhola traz, de certa maneira, norma similar ao Brasil, prevista no artigo 120 da Ley $9 / 2017^{13}$

\footnotetext{
${ }^{12}$ Disponível em:

http://www.ine.es/varipc/verVariaciones.do;jsessionid=405BBACB231CE92967AE7C8B1BAFF5FD

.varipc01 ?idmesini=11\&anyoini=2011\&idmesfin=11\&anyofin=2017\&ntipo=1\&enviar=Calcular. Acesso em: 06 mai 2018.

${ }^{13}$ Artículo 120. Tramitación de emergencia.

1. Cuando la Administración tenga que actuar de manera inmediata a causa de acontecimientos catastróficos, de situaciones que supongan grave peligro o de necesidades que afecten a la defensa nacional, se estará al siguiente régimen excepcional:

a) El órgano de contratación, sin obligación de tramitar expediente de contratación, podrá ordenar la ejecución de lo necesario para remediar el acontecimiento producido o satisfacer la necesidad sobrevenida, o contratar libremente su objeto, en todo o en parte, sin sujetarse a los requisitos formales establecidos en la presente Ley, incluso el de la existencia de crédito suficiente. En caso de que no exista crédito adecuado y suficiente, una vez adoptado el acuerdo, se procederá a su dotación de conformidad con lo establecido en la Ley General Presupuestaria.

b) Si el contrato ha sido celebrado por la Administración General del Estado, sus Organismos Autónomos, Entidades Gestoras y Servicios Comunes de la Seguridad Social o demás entidades públicas estatales, se dará cuenta de dichos acuerdos al Consejo de Ministros en el plazo máximo de treinta días.
} 
Duas características da norma supracitada chamam atenção, quando contrastada com o regramento brasileiro.

A primeira é, novamente, a estruturação mais complexa que a simples citação da possibilidade de dispensa, sendo reforçado o conceito de regulamentação por lei, apresentado no subitem anterior, quando tratados os contratos menores.

A segunda característica é a ausência de um prazo para a execução dos contratos administrativo oriundo deste instituto de tramitación de emergencia. Cumpre relembrar que, no Brasil, contratos de emergência são definidos pela possibilidade de sua execução no prazo de 180 dias e que, no Projeto de Lei $n^{\circ}$ 6814/17, se pretende ampliar para 360 dias.

Esta ausência de prazo legal se dá em razão de outro instituto presente na legislação espanhola, no artigo $119^{14}$, que trata da tramitación urgente del expediente:

c) El plazo de inicio de la ejecución de las prestaciones no podrá ser superior a un mes, contado desde la adopción del acuerdo previsto en la letra a). Si se excediese este plazo, la contratación de dichas prestaciones requerirá la tramitación de un procedimiento ordinario.

d) Ejecutadas las actuaciones objeto de este régimen excepcional, se observará lo dispuesto en esta Ley sobre cumplimiento de los contratos, recepción y liquidación de la prestación.

En el supuesto de que el libramiento de los fondos necesarios se hubiera realizado a justificar, transcurrido el plazo establecido en la letra c) anterior, se rendirá la cuenta justificativa del mismo, con reintegro de los fondos no invertidos.

2. Las restantes prestaciones que sean necesarias para completar la actuación acometida por la Administración y que no tengan carácter de emergencia se contratarán con arreglo a la tramitación ordinaria regulada en esta Ley.

$14 \quad$ Artículo 119. Tramitación urgente del expediente.

1. Podrán ser objeto de tramitación urgente los expedientes correspondientes a los contratos cuya celebración responda a una necesidad inaplazable o cuya adjudicación sea preciso acelerar por razones de interés público. A tales efectos el expediente deberá contener la declaración de urgencia hecha por el órgano de contratación, debidamente motivada.

2. Los expedientes calificados de urgentes se tramitarán siguiendo el mismo procedimiento que los ordinarios, con las siguientes especialidades:

a) Los expedientes gozarán de preferencia para su despacho por los distintos órganos que intervengan en la tramitación, que dispondrán de un plazo de cinco días para emitir los respectivos informes o cumplimentar los trámites correspondientes.

Cuando la complejidad del expediente o cualquier otra causa igualmente justificada impida cumplir el plazo antes indicado, los órganos que deban evacuar el trámite lo pondrán en conocimiento del órgano de contratación que hubiese declarado la urgencia. En tal caso el plazo quedará prorrogado hasta diez días.

b) Acordada la apertura del procedimiento de adjudicación, los plazos establecidos en esta Ley para la licitación, adjudicación y formalización del contrato se reducirán a la mitad, salvo los siguientes:

$1 .^{\circ}$ El plazo de quince días hábiles establecido en el apartado 3 del artículo 153, como período de espera antes de la formalización del contrato.

$2 .^{\circ}$ El plazo de presentación de proposiciones en el procedimiento abierto en los contratos de obras, suministros y servicios sujetos a regulación armonizada, que se podrá reducir de conformidad con lo indicado en la letra b) del apartado 3) del artículo 156.

$3 .^{\circ}$ Los plazos de presentación de solicitudes y de proposiciones en los procedimientos restringido y de licitación con negociación en los contratos de obras, suministros y servicios sujetos a regulación armonizada, que se podrán reducir según lo establecido en el segundo párrafo del apartado 1 del artículo 161 y en la letra b) del apartado 1 del artículo 164, según el caso.

4. ${ }^{\circ}$ Los plazos de presentación de solicitudes en los procedimientos de diálogo competitivo y de asociación para la innovación en contratos de obras, suministros y servicios sujetos a regulación armonizada, no serán susceptibles de reducirse.

5. ${ }^{\circ}$ El plazo de 6 días a más tardar antes de que finalice el plazo fijado para la presentación de ofertas, para que los servicios dependientes del órgano de contratación faciliten al candidato o licitador la información adicional 
Este modelo de contratação em um trâmite de urgência possibilita a redução significativa dos prazos (metade do prazo comum, salvo determinadas exceções) além de ter um regime prioritário para as tramitações internas do órgão.

A aceleração do trâmite processual permite o atendimento à determinação constitucional de licitar sem deixar de observar a necessária urgência administrativa da contratação.

Esta divisão dos contratos administrativos emergenciais em dois institutos permite aos gestores espanhóis separar aquilo que definiram como urgente (que demanda uma atuação mais rápida que casos comuns) daquilo que é definido como emergência (que demanda uma atuação imediata).

Este modelo binomial de contratação emergencial reduz a quantidade de contratações diretas ao mesmo passo em que fornece a celeridade necessária aos casos que demandam um processo mais rápido, mesmo sem configurar uma emergência que urge por solução imediata.

Assim, os contratos emergenciais, realizados sem um processo licitatório prévio, estariam relegados àqueles em que há, de fato, uma necessidade de atuação imediata por meio do poder público, em que aguardar uma ou duas semanas já importaria em um sacrifício insuportável para o interesse público.

\section{Conclusões}

A partir da comparação entre a legislação brasileira e a espanhola, incluindo o Projeto de Lei $n^{\circ}$ 6814/17, ainda em trâmite na Câmara dos Deputados quando da redação do presente artigo, é possível identificar que o Brasil caminha em sentido oposto ao trilhado pela Espanha na busca pela redução da quantidade de contratações diretas.

Quando da análise por meio do direito comparado é fundamental que se tenha a preocupação de não isolar um determinado instituto e importa-lo sem maiores cuidados, sob

solicitada, será de 4 días a más tardar antes de que finalice el citado plazo en los contratos de obras, suministros y servicios sujetos a regulación armonizada siempre que se adjudiquen por procedimientos abierto y restringido.

La reducción anterior no se aplicará a los citados contratos cuando el procedimiento de adjudicación sea uno distinto del abierto o del restringido.

6. ${ }^{\circ}$ Los plazos establecidos en el artículo 159 respecto a la tramitación del procedimiento abierto simplificado, de conformidad con lo señalado en el apartado 5 de dicho artículo.

Las reducciones de plazo establecidas en los puntos $2 .^{\circ}, 3 .^{\circ}$ y $5 .^{\circ}$ anteriores no se aplicarán en la adjudicación de los contratos de concesiones de obras y concesiones de servicios sujetos a regulación armonizada cualquiera que sea el procedimiento de adjudicación utilizado, no siendo los plazos a que se refieren dichos puntos, en estos contratos, susceptibles de reducción alguna.

c) El plazo de inicio de la ejecución del contrato no podrá exceder de un mes, contado desde la formalización. 
pena de trazer um mecanismo que, sem a cultura daquele país, as normas vigentes, as construções históricas e filosóficas, não é aplicável no ordenamento jurídico que o importou.

Estes cuidados devem ser atendidos e, no caso em tela, não há nada que impeça a importação das ideias que vêm se desenvolvendo em matéria de contratação pública na Espanha.

Pelo contrário, a Espanha não possui mandamento constitucional acerca de um dever de licitar, tratando a dispensa como exceção à regra. $\mathrm{O}$ Brasil, sim, deveria ter ainda maior preocupação normativa acerca da redução do número de contratações diretas em atendimento ao texto constitucional.

Desta forma é possível concluir que seria plenamente possível e até mesmo salutar a importação das ideias operadas quanto à redução dos contratos de pequeno valor e dos contratos de emergência, assim entendidos apenas aqueles efetivamente emergenciais.

Esta redução, necessariamente, para que se possibilite a adequada importação, deve ser acompanhada da incorporação, também, dos institutos auxiliares, como um regime de contratação simplificado e/ou super simplificado para contratos de pequeno porte e, a recepção na legislação brasileira de um regime de tramitação de urgência, que tenha a capacidade de aplacar situações que, de fato, são urgentes, ainda que não emergenciais.

Essas alterações normativas possibilitariam o atendimento ao mandamento constitucional ao mesmo tempo em que permitiriam a eficiência necessária à solução dos problemas demandados pelo interesse público.

Mais do que isto, as soluções espanholas poderiam ser importadas com a incorporação de mecanismos tecnológicos que possibilitem a maior eficiência, publicidade e o menor custo na realização dos processos licitatórios.

A Lei $\mathrm{n}^{\circ} 8.666 / 93$ foi redigida com um modus operandi possível em 1993, quando todos os processos precisariam, necessariamente, ser publicados em diário oficial, posto que não haviam portais eletrônicos e de amplo acesso além da sua alta confiabilidade disponíveis.

O mesmo ocorria com a disponibilização dos instrumentos convocatórios e dos documentos de habilitação. Os prazos nela estipulados pressupunham que o licitante precisaria ir até o órgão buscar cópia do edital além dos prazos necessários para obter documentos como certidões do poder público.

Atualmente os editais estão (ou deveriam estar) disponíveis para download imediato na internet e a maioria das certidões também pode ser obtida de forma instantânea. Um exemplo desse avanço tecnológico é a redação do artigo $2^{\circ}$ do Decreto ${ }^{\circ}$ 9094/17 que estabelece a 
vedação da exigência dos usuários de serviços públicos documentos que constem da própria base de dados do Governo.

É inconcebível que no século XXI, com todos os avanços tecnológicos e com a amplitude da internet atual, as licitações sigam exigindo que o licitante entregue certidões que são do próprio Poder Público.

A importação dos institutos aqui tratados somada à simplificação do processo licitatório, com a automatização das verificações da regularidade jurídica, físcal e econômica dos licitantes, além da presença de $100 \%$ dos editais disponíveis para download durante todo o prazo de publicação possibilitariam a redução de custos e prazos dos processos licitatórios permitindo, assim, o efetivo cumprimento do mandamento constitucional de licitar, e bem licitar, no Brasil.

\section{Referências bibliográficas}

BENTO, Eliane. Operação de compras eletrônicas tutorial para usuários dispensa de licitação eletrônica. 2. ed. Campinas: Unicamp, 2016. p. 5. - Disponível em: $<$ https://www.dga.unicamp.br/Conteudos/Documentos/Manual_Operacao_Compras_BEC_SP _Dispensas.pdf>. Acesso em: 27 abr. 2018.

BRASIL. Banco Central do Brasil - Calculadora do Cidadão. Disponível em: https://www3.bcb.gov.br/CALCIDADAO/publico/exibirFormCorrecaoValores.do?method=e xibirFormCorrecaoValores. Acesso em 01 de maio de 2018.

MELLO, Celso Antônio Bandeira de. Curso de direito administrativo. 15. ed. São Paulo: Malheiros, 2003.

MENDES, Renato Geraldo; MOREIRA, Egon Bockmann. Inexigibilidade de licitação: Repensando a contratação pública e o dever de licitar. Curitiba: Zênite, 2016.

NIEBUHR, Joel de Menezes. Licitação pública e contrato administrativo. 4. ed. Belo Horizonte: Fórum, 2015. 
PÚBLICOS, Negócios. Infográficos - informativo do instituto negócios públicos. Curitiba: Negócios Públicos, 2014. Disponível em:

http://www.jacoby.pro.br/novo/Infograficos2014.pdf. Acesso em: 06 maio 2018. 


\title{
SOBRE A DESCONSIDERAÇÃO DA \\ PERSONALIDADE JURÍDICA NO ÂMBITO DA LEI 12.846/13
}

\author{
José Sérgio da Silva Cristóvam \\ Universidade Federal de Santa Catarina - UFSC \\ Gustavo Costa Ferreira
}

Universidade Federal de Santa Catarina - UFSC

\section{Resumo}

O estudo tem por objeto analisar a hipótese de desconsideração da personalidade jurídica da pessoa jurídica sancionada por atos lesivos à Administração Pública, prevista na Lei 12.846/13. Objetiva-se estabelecer critérios de sua interpretação e aplicação. Para tanto, aprofundou-se no contexto de nascimento da legislação, estudou-se o fenômeno da constitucionalização do direito e sua contribuição para estruturação de um regime jurídico de Direito Administrativo Sancionador. Assentou-se conceitos e premissas essenciais a esta investigação a luz do Direito Administrativo Sancionador. Fez-se, então, uma introdução necessária à técnica da desconsideração da personalidade jurídica na legislação brasileira. Finalmente, propôs-se critérios para interpretação e aplicação do art. 14, da Lei 12.846/13.

Palavras-chave: Lei 12.846/13, anticorrupção, constitucionalização do Direito, Direito Administrativo sancionador, desconsideração da pessoa jurídica.

\section{Abstract/Resumen/Résumé}

The purpose of this review is to analyze the disregard of the legal entity provision in the Brazilian Anti-Corruption Law (Law no. 12,846/13), intended to sanction entities for harmful acts against the Public Administration. It aims to establish criteria for the interpretation and application of the disregard provision in study. In order to do so, we reviewed the birth context of the aforementioned federal law, we studied the Constitutionalization of Law phenomenon and its contribution to the structuring of a Punitive Administrative legal regime. Therefore, essentials concepts and premises to this investigation were established in light of the Sanctioning Administrative Law. Then, a necessary introduction was made to the disregard of legal person technique in Brazilian legislation. Finally, we suggested criteria for the interpretation and application of article 14, of the Law 12,846/13. 
Keywords/Palabras-claves/Mots-clés: Federal Law No. 12.846/13, anti-corruption, constitutionalization of Law, sanctioning Administrative Law, disregard of legal entity doctrine.

\section{Introdução}

O estudo pretende analisar a técnica da desconsideração da personalidade jurídica na Lei $n^{o}$ 12.846, de $1^{\text {o }}$ de agosto de 2013 (BRASIL, 2013), também chamada de Lei Anticorrupção, Lei da Empresa Limpa ou Lei da Corrupção Empresarial. Considerando-se a inexistência de consenso mínimo sobre a alcunha da norma, essa será tratada aqui, sobretudo, pelo seu número de nascimento.

De início, nesta parte introdutória, convém afastar a impressão, ainda que inconsciente, de que a Lei ${ }^{0}$ 12.846/13 teria sua aplicação destinada apenas às grandes empreiteiras do Brasil, envolvidas na chamada "Operação Lava Jato". Supostos corruptos sem rosto, distantes da realidade cotidiana dos autoconclamados "cidadãos de bem".

Não se pode esquecer que a norma é geral e abstrata, razão pela qual sua aplicação ocorre indistintamente a todas as pessoas jurídicas, conforme conceituação legal do parágrafo único do seu art. $1^{\circ}$ (BRASIL, 2013). A legislação tem aplicação às microempresas e empresas de pequeno porte Brasil afora, com impacto direto em micro e pequenos empresários e milhões de empregados, pessoas de carne e osso cujos destinos podem ser comprometidos sem qualquer envolvimento direto em atos lesivos à Administração Pública.

Disso cumpre destacar dois problemas centrais sobre os quais se pretende debruçar o estudo. Primeiro, saber se seria constitucional desconsiderar a personalidade jurídica para estender sanções aos administradores e/ou sócios-administradores de empresas? Se positiva a resposta, quais os respectivos critérios de interpretação/aplicação e quais seus pressupostos?

Isso, inclusive, justifica a relevância do debate sobre seus contornos de aplicação e a tentativa de refino das suas hipóteses de abrangência. Eis os contornos básicos do debate aqui estabelecidos, a assentar sobre alguns pontos destacados e controvertidos do fenômeno da desconsideração da personalidade jurídica das empresas no âmbito da Lei $\mathrm{n}^{0}$ 12.846/13 (BRASIL, 2013). 


\section{O contexto do nascimento da Lei $n^{0} 12.846 / 13$ e o regramento normativo internacional}

O combate à corrupção ${ }^{1}$ é questão de destacada atenção no cenário internacional. Diversos são os tratados e convenções que engrossam as fileiras dessa (aparente) guerra declarada às práticas de corrupção. É possível, também, afirmar a existência de verdadeiro bloco normativo internacional anticorrupção, alguns dos quais o Brasil é signatário, a saber: (i) a Convenção Inter-Americana Contra a Corrupção de 1996, capitaneada pela Organização dos Estados Americanos (OEA), aprovada internamente pelo Decreto Legislativo n. 152, de 25 de junho de 2002, e promulgada pelo Decreto Presidencial n. 4.410, de 07 de outubro de 2002 (BRASIL, 2002); (ii) a Convenção sobre o Combate da Corrupção de Funcionário Públicos Estrangeiros em Transações Comerciais Internacionais da Organização para a Cooperação e Desenvolvimento Econômico (OCDE) de 1997, ratificada internamente em 15 de junho de 2000 e promulgada pelo Decreto Presidencial n. 3.678, de 30 de novembro de 2000 (BRASIL, 2000); e, (iii) a Convenção das Nações Unidas contra Corrupção de 2003, ratificada pelo Brasil por meio do Decreto Legislativo n. 348, de 18 de maio de 2005, e promulgada pelo Decreto Presidencial n. 5.687, de 31 de janeiro de 2006 (BRASIL, 2006). ${ }^{2}$

Dentre outros compromissos, referidos diplomas internacionais determinavam aos signatários a instituição de um conjunto normativo voltado ao combate à corrupção, ${ }^{3}$ inclusive com a disciplina da responsabilização das pessoas jurídicas envolvidas em esquemas de corrupção, preferencialmente, de índole penal e, se isso não fosse possível em razão do sistema jurídico do país signatário, de índole não-penal com a imposição de sanções "eficazes, proporcionais e dissuasivas", nos termos do art. $2^{\circ}$ e $3^{\circ}$, da mencionada Convenção da OCDE e do art. 26 da Convenção das Nações Unidas contra Corrupção. ${ }^{4}$

Envolto nesse cenário, aliado a outros fatores, surge a Lei $\mathrm{n}^{\mathrm{o}}$ 12.846/13 (Lei Anticorrupção), que ingressou às pressas no ordenamento jurídico nacional. O projeto de lei 6.826/2010, que tramitava desde $18.02 .2010^{5}$ na Câmara dos Deputados, restou aprovado em

\footnotetext{
${ }^{1}$ Para uma recuperação histórica sobre as supostas raízes da corrupção no Brasil, ver: FAORO, 2001; HOLANDA, 1995. Para uma interessante e sofisticada releitura crítica sobre o tema, ver: SOUZA, 2017; SOUZA, 2015.

${ }^{2}$ Para uma análise das Convenções Anticorrupção da OEA e da OCDE ver: RAMINA, 2003. p. 186-198.

${ }^{3}$ Sobre o tema, até 15/09/2016 tramitavam no Senado 98 proposições relacionadas ao combate à corrupção e 344 na Câmara dos Deputados. Nesse sentido, ver: MOHALLEM; RAGAZZO, 2017. p. 20.

${ }^{4}$ Sobre a influência da Convenção da OCDE no Direito Espanhol, ver: FARALDO CABANA, 2012. p. 1-20.

5 Informações extraídas do site da Câmara dos Deputados. Disponível em: $<$ http://www.camara.gov.br/proposicoesWeb/fichadetramitacao?idProposicao=466400 $>$. Acesso em: 19 out. 2018.
} 
menos de um mês de tramitação no Senado Federal, em 04 de julho de $2013 .{ }^{6}$ A inspiração do projeto nos citados compromissos internacionais é objeto de expressa menção nos parágrafos $7^{\mathrm{o}}$ e $8^{\mathrm{o}}$ da exposição de motivos apresentada na proposta do respectivo anteprojeto da lei, ${ }^{7}$ subscrita por Jorge Hage Sobrinho, Tarso Fernando Herz Genro e Luis Inácio Lucena Adams. ${ }^{8}$

Embora não seja objeto desse estudo a investigação dos motivos da apressada aprovação do projeto, especula-se que isso possa/deva ser creditado (em alguma medida) às manifestações populares de meados de 2013, Pré-Copa das Confederações da FIFA, que clamavam por mudanças, por moralidade administrativa e pelo maior combate à corrupção.

A pressa na aprovação do projeto teve seu preço. Não são raros os seus dispositivos e institutos a reclamar considerável esforço hermenêutico para sanar possíveis incongruências e, em especial, incompletudes.

Seja como for, o fato é que a Lei $n^{\circ} 12.846 / 13$ foi aprovada e está em pleno vigor na ordem normativa brasileira, de modo que, ausente qualquer perspectiva de reforma legislativa, cabe ao jurista trabalhar com a matéria-prima existente, com o estudo e análise dos seus dispositivos, integrando eventuais lacunas, assim como conferindo-lhes interpretação e aplicação mais consentânea ao respectivo sistema jurídico constitucional, notadamente aos direitos e garantias fundamentais do acusado assegurados em nossa ordem constitucional.

\section{O regime de responsabilização inaugurado pela Lei $\mathbf{n}^{0} \mathbf{1 2 . 8 4 6 / 1 3}$}

A Lei $n^{0}$ 12.846/13 inaugurou o regime de responsabilização objetiva, no âmbito cível e administrativo, das pessoas jurídicas por atos lesivos à Administração Pública. Especificamente sobre esse tema, inicialmente cumpre alertar que a responsabilização criminal

\footnotetext{
6 Informações extraídas do site do Senado Federal. Disponível em: $<$ http://www.senado.gov.br/atividade/materia/detalhes.asp?p_cod_mate=113244>. Acesso em: 19 out. 2018.

${ }^{7}$ Disponível em: <http://www.camara.gov.br/sileg/integras/1084183.pdf>. Acesso em: 19 out. 2018.

${ }^{8}$ Nesse sentido, ver: “[...] 7. Além disso, o anteprojeto apresentado inclui a proteção da Administração Pública estrangeira, em decorrência da necessidade de atender aos compromissos internacionais de combate à corrupção assumidos pelo Brasil ao ratificar a Convenção das Nações Unidas contra Corrupção (ONU), a Convenção Interamericana de Combate à Corrupção (OEA) e a Convenção sobre o Combate da Corrupção de Funcionários Públicos Estrangeiros em Transações Comerciais Internacionais da Organização para Cooperação e Desenvolvimento Econômico (OCDE). 8. Com as três Convenções, o Brasil obrigou-se a punir de forma efetiva as pessoas jurídicas que praticam atos de corrupção, em especial o denominado suborno transnacional, caracterizado pela corrupção ativa de funcionários públicos estrangeiros e de organizações internacionais. Dessa forma, urge introduzir no ordenamento nacional regulamentação da matéria - do que, aliás, o país já vem sendo cobrado -, eis que a alteração promovida no Código Penal pela Lei n. 10.467, de 11 de junho de 2002, que tipificou a corrupção ativa em transação comercial internacional, alcança apenas as pessoas naturais, não tendo o condão de atingir as pessoas jurídicas eventualmente beneficiadas pelo ato criminoso" (BRASIL, 2010).
} 
da pessoa jurídica encontra barreira constitucional no mínimo de difícil transposição, porquanto somente admitida para crimes ambientais, por expressa previsão do art. $225, \S^{\circ}$, da Constituição Federal (BRASIL, 1988).

Com efeito, cabe considerar que a previsão normativa em análise transmite certos ares de festiva tranquilidade, sobretudo àqueles que se colocam como arautos da moralidade e ferrenhos combatentes da corrupção. No âmbito jurídico, isso inclusive é perceptível nos corredores dos tribunais e repartições do sistema de justiça, povoando também os corredores das faculdades de Direito. Sob o ímpeto punitivista, reputa-se que a caracterização dessa responsabilidade seria mais suavizada, a exemplo da responsabilidade objetiva fundada no risco da atividade administrativa (art. 37, $\S 6^{\circ}$ da Constituição de 1988) ou daquela do Direito do Consumidor (arts. 12 a 14 do Código de Defesa do Consumidor). Afinal de contas, trata-se de responsabilização objetiva e que, aliado a isso, não é criminal. Contudo, esse quadro deve ser visto com certo temperamento.

Os contornos desse trabalho impedem que aqui se avance para um maior aprofundamento do tema. No entanto, de modo bastante sintético, antecipa-se que o apontado temperamento na responsabilização objetiva da pessoa jurídica por atos de corrupção se justifica pelo fato de a Lei $n^{\circ} 12.846 / 13$ traduzir norma jurídica destinada à imposição de sanções e que, portanto, atrai incidência do regime jurídico comum ao Direito Administrativo sancionador, diferentemente dos dois outros regimes de responsabilização acima referidos (BRASIL, 2013). Note-se que, se comparadas as sanções estatuídas nos seus arts. $6^{\circ}$ e 19 com aquelas previstas às pessoas jurídicas por crimes ambientais (arts. 21,22 e 24 da Lei ${ }^{\circ}$ 9.605/98) (BRASIL, 1998), fica evidente que as medidas aflitivas da Lei no 12.846/13 são mais gravosas ou, no mínimo, muito semelhantes às de índole penal daquela legislação ambiental, razão pela qual há que se ter cuidado com aquela inadvertida tranquilidade. Abaixo, uma tabela comparativa das sanções evidencia essa semelhança, quase identidade, ${ }^{910}$ das duas normas repressoras:

\footnotetext{
${ }^{9}$ Importa observar que, via de regra, ao legislador incumbe a definição de ilícitos como penais e/ou como administrativos, guardadas as hipóteses constitucionais em que há obrigatória tipificação penal ou tipificação penal interditada, conforme lição de Osório (2015. p. 125).

${ }^{10}$ Essa identidade ou quase-identidade das sanções contra as pessoas jurídicas em tais diplomas normativos é sintomática da indiferença ontológica entre ilícitos administrativos e penais. É dizer, não há diferenças materiais ou essenciais entre tais injustos. Ao Legislador incumbirá fazer essa distinção. Sobre o tema, ver: CEREZO MIR (1975) e ALARCÓN SOTOMAYOR (2014).
} 


\begin{tabular}{|c|c|}
\hline Crimes Ambientais (Lei 9.605/98) & Atos Lesivos à Administração (Lei 12.846/13) \\
\hline Multa (art. 21, 1) & Multa (art. 60, 1) \\
\hline $\begin{array}{l}\text { Pena restritiva de direitos e prestação de } \\
\text { serviços à comunidade (art. } 21 \text {, II e II) }\end{array}$ & $\begin{array}{l}\text { Publicação extraordinária da decisão } \\
\text { condenatória (art. 6요, II) }\end{array}$ \\
\hline $\begin{array}{l}\text { Suspensão parcial ou Total de atividades } \\
\text { (art. } 22,1 \text { ) e Interdição temporária de } \\
\text { estabelecimento, obra ou atividade (art. } 22 \text {, } \\
\text { II) }\end{array}$ & $\begin{array}{c}\text { Suspensão ou interdição parcial de suas } \\
\text { atividades (art. 19, II) }\end{array}$ \\
\hline $\begin{array}{l}\text { Proibição de contratar com o Poder Público, } \\
\text { bem como dele obter subsídios, subvenções } \\
\text { ou doações por prazo inferior a } 10 \text { anos (art. } \\
22,111 \text { e } \$ 3 \% \text { ) }\end{array}$ & $\begin{array}{c}\text { Proibição de receber incentivos, subsídios, } \\
\text { subvenções, doações ou empréstimos de órgãos } \\
\text { ou entidades públicas e de instituições } \\
\text { financeiras púlicas ou controladas pelo poder } \\
\text { público, pelo prazo mínimo de } 1 \text { (um) e máximo } \\
\text { de } 5 \text { (cinco) anos (art. } 19, \text { IV) }\end{array}$ \\
\hline Perdimento de bens (art. 24) & $\begin{array}{l}\text { Perdimento de bens, direitos ou valores que } \\
\text { representem vantagem ou proveito direta ou } \\
\text { indiretamente obtidos da infração (art. 19, 1) }\end{array}$ \\
\hline Liquidação forçada (art. 24) & $\begin{array}{c}\text { Dissolução compulsória da pessoa jurídica (art. } \\
19, \text { III) }\end{array}$ \\
\hline
\end{tabular}

Assim, resta claro que a legislação em exame é norma sujeita ao regime jurídico comum ao Direito Administrativo sancionador. ${ }^{11}$ Conforme se pretende demonstrar, a existência desse regime jurídico-administrativo sancionatório tem fonte constitucional, em boa medida até decorrência necessária do próprio fenômeno da constitucionalização do Direito Administrativo.

Antes, porém, de adentrar ao tema objeto de investigação, convém discorrer, brevemente, sobre o fenômeno da constitucionalização do Direito Administrativo e seus reflexos na construção do referido regime jurídico-administrativo sancionatório.

\footnotetext{
${ }^{11}$ As medidas de referência que atraem a incidência dos princípios e regras de direito administrativo sancionador consistem nos institutos da infração e sanção administrativas. Não cabe, aqui, trazer um conceito desses institutos, impondo-se assinalar, tão somente, que o conceito de sanção administrativa no Direito Brasileiro não está vinculado ao elemento "autoridade administrativa", mas à presença formal e material da Administração Pública. Sanções administrativas podem ser, sim, aplicadas por autoridades judiciárias, sem que isso descaracterize sua natureza administrativista. O conceito que se adere, portanto, é mais amplo que o conceito propugnado pela doutrina espanhola e parte da doutrina brasileira, o qual está visceralmente ligado à presença da autoridade administrativa como sujeito responsável pela imposição da penalidade. Sobre conceito de sanção administrativa independente da autoridade administrativa como sujeito impositor da sanção, ver: OSÓRIO, 2015. p. 107. Sobre conceito de sanção administrativa dependente da autoridade administrativa, ver: OLIVEIRA, 2005. p. 52; FERREIRA, 2001. p. 173; VITTA, 2003. p. 62; REBOLLO PUIG et al, 2005. p. 24-25 e RAMÍREZ TORRADO, 2007. p. 274-275.
} 


\section{A constitucionalização do Direito Administrativo e o regime jurídico- administrativo sancionatório}

No Brasil, apenas com a promulgação da Constituição de 1988 é que se passou a verificar, com maior intensidade, o fenômeno da constitucionalização do Direito no nosso sistema jurídico.

A expressão, como se nota, é plurissignificativa, ${ }^{12}$ podendo albergar mais de um sentido, ideia ou noção. Assim, para evitar desencontros interpretativos, convém propor um acordo semântico, de que a referida locução será aqui utilizada para encerrar a ideia de "um efeito expansivo das normas constitucionais, cujo conteúdo material e axiológico se irradia, com força normativa, por todo o sistema jurídico" (BARROSO, 2008. p. 32).

A repercussão desse fenômeno pode ser identificada nas mais variadas searas do Direito, ao que o Direito Administrativo não está e nem poderia estar imune. Como consequência direta desse fenômeno, cumpre identificar em certa medida, por exemplo, "um interessante e sofisticado movimento de substituição da legalidade, como fonte reitora da disciplina jurídico-administrativa, pela própria Constituição, fator de verticalização e direta parametrização normativa da atuação administrativa" (CRISTÓVAM, 2015. p. 212).

A própria técnica da interpretação conforme a Constituição pode ser catalogada como outro resultado direto desse fenômeno. Segundo ela, o intérprete deve descartar possibilidades interpretativas que tornem a norma incompatível com ordem constitucional (BINENBOJM, 2008. p. 67). Portanto, essa abordagem impõe balizas constitucionais à interpretação jurídicas de todas as instituições jurídico-administrativas (JUSTEN FILHO, 2008. p. 83).

Com efeito, a constitucionalização do Direito labora não apenas na releitura dos tradicionais institutos do regime jurídico-administrativo, repercutindo igualmente nos novos institutos e estruturas da disciplina administrativa, na sua conformação aos princípios e regras constitucionais, mais precisamente a partir da modulação dos seus critérios de interpretação e aplicação, devidamente constitucionalizados. ${ }^{13}$ É o que ocorre com a Lei $n^{0} 12.846 / 13$, que

\footnotetext{
${ }^{12}$ Em um sentido bastante ampliado, Barroso (2008. p. 31-32) explica que é possível empregar a locução constitucionalização do Direito para caracterizar qualquer ordenamento jurídico no qual vigore uma Constituição dotada de supremacia. Pode, igualmente, "servir para identificar, ademais, o fato de a Constituição formal incorporar em seu texto inúmeros temas afetos aos ramos infraconstitucionais do direito".

${ }^{13}$ Nesse sentido: "[...] a construção de um renovado regime jurídico-administrativo deve ser edificada sobre as bases do fenômeno do movimento de constitucionalização do Direito em geral, e do Direito Administrativo em especial. A constitucionalização do Direito, que no Brasil somente passa a operar mais firmemente a partir do advento da Constituição Cidadã, acaba por inaugurar um processo de reestruturação não somente das bases da teoria constitucional, mas da própria disciplina jurídica em geral, espraiando renovadas luzes e reflexos normativos em todas as direções e aos mais longínquos e recônditos espaços do universo jurídico nacional" (CRISTÓVAM, 2015. p. 325).
} 
nasce quase que 25 anos pós-Constituição de 1988, pelo que seus institutos e disposições devem sofrer essa filtragem constitucional, analisados e aplicados à luz das regras e princípios constitucionais (BARROSO, 2008. p. 43).

Nesse contexto, cabe extrair do texto constitucional princípios e regras que incidem diretamente no exercício da competência sancionadora do Estado, a formar verdadeiro regime jurídico limitador da potestade administrativa sancionatória - aqui referida por Direito Administrativo sancionador -, uma ordem de direitos e garantias fundamentais dos acusados. Tal regime tem como fundamento: (i) a opção brasileira por um Estado democrático de direito (MELLO, 2007. p. 103); (ii) o direito fundamental ao devido processo legal, assegurado aos acusados em geral nos processos judiciais ou administrativos, nos termos do art. $5^{\circ}$, LIV, da Constituição Federal (OSÓRIO, 2015. p. 129); e, (iii) a própria identidade ontológica entre os ilícitos administrativos, o que reconhece certa liberdade do legislador para rotulá-los como bem lhe aprouver, mas não lhe reconhece prerrogativa para dispor das garantias dos acusados. Há, ainda, quem defenda que a existência de um regime desse cariz se justificaria pelo só fato da imissão estatal nos direitos e garantias fundamentais em razão da prática de uma infração. ${ }^{14}$

Seja como for, parte-se da ideia da existência de um regime jurídico-administrativo sancionador comum ao Direito brasileiro. Importa registrar que, inicialmente, o Direito Administrativo sancionador toma por empréstimo princípios e regras comuns ao Direito Penal, assim como parte de suas construções teóricas. Trata-se de simples inspiração inicial em razão da maior evolução científica desta disciplina. No entanto, assiste razão à Suay Rincon (2008. p. 51) ao assinalar que "superado el vacío y alcanzada la madurez, la criatura podría empezar a echar a volar em solitario y por su propia cuenta". Em vista disso, a tarefa desse estudo também está em delimitar o conteúdo normativo desses direitos e garantias no âmbito da desconsideração da personalidade jurídica prevista na Lei no ${ }^{0}$ 12.846/13 (BRASIL, 2013). ${ }^{15}$

Os princípios e regras penais aplicam-se com certos matizes e graduações ao Direito Administrativo sancionador, respeitados conteúdos mínimos obrigatórios.Tais graduações são influenciadas pelo que está em jogo na aplicação da norma repressora, quais direitos fundamentais dos acusados serão objeto de limitação caso haja imposição da sanção. São influenciados, ainda, pela extensão e a gravidade dessa restrição. É dizer, quanto maior a restrição, maiores serão as garantias asseguradas aos acusados (OSÓRIO, 2015. p. 144).

\footnotetext{
${ }^{14}$ Nesse sentido, ver: COSTA, 2013. p. 176.

${ }^{15}$ A tal "grito de independência" do Direito Administrativo sancionador em relação ao Direito Penal, quando ele passa a caminhar com suas próprias pernas, Nieto soe designar de "giro administrativo" (2007. p. 8).
} 
No caso específico da Lei $\mathrm{n}^{\mathrm{o}} 12.846 / 13$, já se demonstrou que há considerável semelhança, quase identidade, entre as suas sanções e àquelas previstas na Lei $n^{\circ}$ 9.605/98 (Lei de Crimes e Infrações Ambientais) (BRASIL, 1998). Por consequência, são quase idênticos ou muito semelhantes os conteúdos normativos dos direitos e garantias fundamentais à disposição da pessoa jurídica situada na posição de acusada nos processos de responsabilização da Lei $n^{\circ}$ 12.846/13 (BRASIL, 2013).

Eis as premissas hermenêuticas fundamentais à análise de quaisquer disposições da Lei $\mathrm{n}^{\mathrm{o}} 12.846 / 13$, as quais uma vez assentadas, resta franqueado o acesso ao tema propriamente dito, objeto desta investigação.

\section{Algumas considerações sobre a desconsideração da personalidade jurídica}

A desconsideração da personalidade jurídica ${ }^{16}$ consubstancia-se, tradicionalmente, em técnica tendente a afastar a autonomia patrimonial entre pessoa jurídica e as pessoas físicas a ela vinculadas, isto é, seus sócios e/ou administradores, gerentes e dirigentes. ${ }^{17}$ Seu objetivo é responsabilizar tais pessoas físicas pelas obrigações societárias não satisfeitas.

Em linhas gerais, por autonomia patrimonial entende-se a distinção entre o patrimônio da pessoa jurídica (patrimônio social) e dos sócios que a constituíram. Essa autonomia garante, minimamente, a existência de uma ordem de preferência (benefício de ordem) em desfavor dos bens societários para fins de satisfação das obrigações sociais não adimplidas. Equivale dizer que os bens particulares dos sócios não podem ser executados por dívidas da sociedade, senão depois de executados os bens sociais, conforme preceitua o art. 1.024 do Código Civil (BRASIL, 2002). A autonomia patrimonial pode, em outros casos, significar impedimento legal a que os bens dos sócios respondam pelas dívidas sociais, tal como ocorre nas sociedades limitadas, por força do art. 1.052 do Código Civil, na qual a responsabilidade do sócio resta limitada à sua participação societária. Seja como for, referida autonomia patrimonial é garantia

\footnotetext{
${ }^{16}$ Vale mencionar as variações terminológicas e linguísticas da técnica da desconsideração da personalidade ao redor do mundo, inventariadas por Clápis (2006. p. 51), a saber: disregard of legal entity, disregard of corporate entity, lifting the corporate veil, piercing the corporate veil, nos Direitos Inglês e Norte-americano; superamento de la personalitá giuridica, no Direito Italiano; Durchgriff der juristichen Person, no Direito Alemão; teoria de la penetración o desestimación de la personalidad, no Direito Argentino; e, mise à l'ecart de la personnalité morale, no Direito Francês.

${ }^{17}$ Um conceito mais teleológico deste instituto é oferecido por Moraes (2009. p. 1), para quem "a desconsideração da personalidade jurídica é o instrumento utilizado pelo direito para coibir atitudes eivadas de fraude que desvirtuam os fins para os quais a sociedade empresária é criada”.
} 
fundamental intrinsecamente vinculada à livre de iniciativa, princípio geral da atividade econômica brasileira por força do art. 170, caput, da Constituição de 1988 (BRASIL, 1988).

A desconsideração da personalidade jurídica pode, ainda, ser utilizada para afastar a autonomia patrimonial entre pessoas jurídicas vinculadas, ${ }^{18}$ responsabilizando pessoas jurídicas do mesmo grupo econômico ${ }^{19}$ por obrigações de uma das outras, ou, igualmente, para ser atingido o patrimônio do "sócio oculto" da pessoa jurídica, essa última hipótese conhecida como desconsideração expansiva da personalidade jurídica. ${ }^{20}$

Em arremate, eventualmente a técnica pode se apresentar em sua modalidade inversa, por meio da qual se imputa à sociedade responsabilidade por obrigações não cumpridas pelos sócios (PEREIRA JUNIOR, 2010. p. 55). ${ }^{21}$

Trata-se de técnica cuja assimilação inicial e posterior evolução podem ser creditadas sobremaneira à jurisprudência e à doutrina. Apesar disso, no ordenamento jurídico brasileiro existem algumas regras desconsideradoras expressamente contempladas, a dizer: o art. 135 do Código Tributário Nacional; o art. 28 da Lei no 8.087/90 (Código de Defesa do Consumidor); o art. $4^{\circ}$ da Lei $n^{\circ}$ 9.605/98 (Lei de Crimes e Infrações Ambientais); o art. 50 do Código Civil; o art. 34 da Lei n ${ }^{\circ}$ 12.529/11 (Lei de Defesa da Concorrência); e, mais recentemente, o art. 14 da Lei 12.846/13 (Lei Anticorrupção) (BRASIL, 1966; 1990; 1998; 2002; 2011; 2013).

Por interessar à investigação proposta, convém trazer a lume a classificação das diversas técnicas de desconsiderações em teoria maior ou teoria menor. Explica Gonçalves

\footnotetext{
${ }^{18} \mathrm{O}$ embrião de um conceito legal de pessoas jurídicas vinculadas pode ser recuperado do art. 243 da Lei $\mathrm{n}^{\circ}$ 6.404/76 (Lei das S.A.'s), por meio do qual o legislador traz os conceitos de sociedades coligadas e controladas. Noção semelhante pode ser extraída do art. 23 da Lei n ${ }^{\circ}$ 12.973/14, que, dentre outras matérias, dispôs sobre a tributação da pessoa jurídica domiciliada no Brasil, com relação ao acréscimo patrimonial decorrente de participação em lucros auferidos no exterior por controladas e coligadas.

${ }^{19}$ Vale lembrar que sociedade matriz e sociedade filial afiguram-se faces distintas de uma mesma pessoa jurídica. A distinção entre uma e outra interessa mais ao Direito Tributário, em geral não se estendendo às demais áreas do Direito, como o Direito Administrativo.

${ }^{20}$ São parcos os trabalhos sobre referida modalidade de desconsideração da personalidade jurídica. Destaca-se monografia elaborada por Corrêa (2011) e, ainda, de forma incidental, a abordagem na decisão liminar do MS 32.494 (STF), de lavra do Min. Celso de Mello.

${ }^{21}$ É digna de nota a lição Justen Filho (1987. p. 55-56), resgatada por Clápis (2006. p. 51), quando pontua os elementos conjugadores da formação do conceito da desconsideração da pessoa jurídica: “(i) existência de uma ou mais sociedades personificadas, em que os sócios pessoas físicas ou jurídicas, são tratados distintamente da sociedade, e as diversas sociedades personificadas, porém vinculadas entre si por laços de coligação ou controle, que são tratadas individualmente; (ii) ignorância dos efeitos da personificação, ou seja, afastamento das regras relativas à personificação; (iii) ignorância de tais efeitos para o caso concreto, vale dizer, com a caracterização da desconsideração, a pessoa jurídica não se torna inválida ou inexistente, apenas suspendem-se os efeitos da personificação a algum ato específico, a um período determinado da atividade da sociedade, ou a um relacionamento específico entre a pessoa jurídica e certa pessoa; (iv) manutenção da validade de atos específicos, que não é sinônimo de invalidação dos atos jurídicos. Os atos jurídicos permanecem válidos, porém os efeitos da personalidade jurídica são considerados ineficazes. A carência de elemento ou de pressuposto de validade para o ato não significa superar a personalidade; e (v) a fim de efetivar perecimento de um interesse, o que significa afirmar que a finalidade da desconsideração é ignorar os efeitos da personificação em determinado caso, em razão do risco da conduta adotada em sacrificar um interesse tutelado pelo direito".
} 
(2016. p. 205) que na teoria maior "a comprovação da fraude e do abuso por parte dos sócios constitui requisito para que o juiz possa ignorar a autonomia patrimonial das pessoas jurídicas". A teoria menor, por outro lado, "considera o simples prejuízo do credor motivo suficiente para a desconsideração", tal como ocorre no art. $28, \S 5^{\circ}$, do Código de Defesa do Consumidor, onde se pode levar a efeito desconsideração da pessoa jurídica "sempre que sua personalidade for, de alguma forma, obstáculo ao ressarcimento de prejuízos causados aos consumidores" (BRASIL, 1990). Situação análoga se verifica no art. 4º da Lei de Crimes e Infrações Ambientais (BRASIL, 1998).

Refoge aos objetivos dessa investigação historiar e minudenciar a técnica da desconsideração da pessoa jurídica, impondo-se apenas delimitar noções preliminares para facilitar sua análise na Lei $n^{\circ} 12.846 / 13$, que é do que se cuidará a seguir.

\section{A desconsideração da personalidade jurídica no âmbito da Lei no 12.846/13}

Há muita controvérsia se seria lícito à Administração desconsiderar no âmbito administrativo personalidades jurídicas, bem como se haveria necessidade de previsão legal dessa competência/prerrogativa. Há entendimento pela reserva de jurisdição para levar a efeito eventual desconsideração de pessoa jurídica, caso em que, supõe-se, seria imperativa a verificação da presença dos pressupostos do art. 50 do Código Civil (BRASIL, 2002). Há, ainda, interessante defesa no sentido da possibilidade de desconsideração na seara administrativa, desde que amparada em expressa previsão legal, com fundamento no princípio constitucional da legalidade administrativa. Por fim, uma tese bastante ampliativa sustenta que seria lícito à Administração desconsiderar a personalidade jurídica na esfera administrativa, mesmo sem previsão em lei, com base nos princípios constitucional-administrativos da moralidade e da eficiência. ${ }^{22}$

Seja como for, essa discussão perde um pouco em relevo para os processos de responsabilização deflagrados com base na Lei $n^{\circ}$ 12.846/13, vez que há inequívoca disposição legal acolhendo a disregard doctrine nessa seara, como se colhe do art. 14 da referida norma, ora transcrito:

\footnotetext{
${ }^{22}$ A matéria será objeto de apreciação pelo Supremo Tribunal Federal no Julgamento do já citado MS 32.494, hoje sob a Relatoria do Min. Celso de Mello. Para uma breve introdução ao tema, recomenda-se a leitura da decisão liminar proferida na referida ação.
} 
Art. 14. A personalidade jurídica poderá ser desconsiderada sempre que utilizada com abuso do direito para facilitar, encobrir ou dissimular a prática dos atos ilícitos previstos nesta Lei ou para provocar confusão patrimonial, sendo estendidos todos os efeitos das sanções aplicadas à pessoa jurídica aos seus administradores e sócios com poderes de administração, observados o contraditório e a ampla defesa (BRASIL, 2013).

Com efeito, o dispositivo alberga uma peculiaridade existente até então apenas na legislação de defesa da concorrência (Lei no 12.529/11), que parece não ter sido tratada com a devida importância. Ao contrário das demais hipóteses de disregard of legal person, tal dispositivo, a reboque do que foi previsto no art. 34 da Lei $\mathrm{n}^{\circ}$ 12.529/11, autoriza a desconsideração para fins de extensão de sanção aos sócios com poderes de administração e aos administradores da pessoa jurídica sancionada. Tradicionalmente, as normas desconsideradoras previstas no art. 135 do CTN, no art. 28 do Código de Defesa do Consumidor, no art. $4^{\circ}$ da Lei $9.605 / 98$ e no art. 50 do Código Civil, admitem a possibilidade de se redirecionar as pessoas físicas obrigações ressarcitórias da pessoa jurídica, ${ }^{23}$ mas não sanções administrativas, o que impõe, nessa parte, o necessário teste de constitucionalidade dessa inovação legislativa.

Assim, são basicamente duas as questões centrais em torno das quais gravita este estudo, a saber: é constitucional desconsiderar a personalidade jurídica da pessoa jurídica para o fim de estender sanções aos seus administradores e/ou sócios-administradores? Em caso afirmativo, quais seriam os critérios de interpretação e aplicação dessa hipótese desconsiderativa e quais seriam seus pressupostos? É do que se cuidará nas linhas seguintes.

\subsection{Sobre a (in)constitucionalidade da desconsideração de personalidade jurídica para extensão de sanções aos administradores elou sócios-administradores da pessoa jurídica}

A pretensão de desconsideração da personalidade jurídica de sociedade empresarial para atribuir aos seus sócios-administradores e administradores sanções a ela imposta parece esbarrar firmemente no direito fundamental do acusado à intranscendência da pena (nenhuma pena passará da pessoa do condenado), proibição abrigada no art. $5^{\circ}$, XLV, da Constituição de 1988 (BRASIL, 1988).

\footnotetext{
${ }^{23}$ Há clara diferença teleológica entre obrigações ressarcitórias e sanções administrativas. A primeira se preocupa com a reparação do dano à vítima, bem traduzida pela ideia de retorno ao status quo ante. A segunda objetiva, preponderantemente, a retribuição/punição do infrator, aliada a uma finalidade de prevenção geral e especial do ilícito. Sobre o tema, ver: OSÓRIO, 2015. p. 114 e REBOLLO PUIG, 2000. p. 174.
} 
Na mesma esteira, parece igualmente esbarrar no Pacto de San José da Costa Rica (BRASIL, 1992), que em seu no seu art. $5^{\circ}$, item 3, dispõe que "a pena não pode passar da pessoa do delinquente". Inclusive, cumpre recordar que tal norma convencional goza de caráter supralegal, tendo o condão de paralisar a eficácia jurídica de toda e qualquer disciplina normativa infraconstitucional com ela conflitante, tal como decidido pelo Supremo Tribunal Federal, no RE 466.343, sob relatoria do Min. Cezar Peluso (BRASIL, 2008).

Percebe-se, portanto, que inserido o referido dispositivo constitucional no regime jurídico-administrativo sancionatório, sua interpretação conduz à vedação de transcendência da sanção, salvo na obrigação de reparação de dano - que não é sanção, a propósito - e no perdimento de bens. ${ }^{24} \mathrm{Na}$ mesma esteira, o dispositivo convencional parece ser ainda mais amplo ao não admitir a transcendência em qualquer hipótese de sancionamento.

Parece possível reconhecer que o legislador tenha certa medida de liberdade para a conformação/formatação das infrações como criminais e/ou administrativas. Não tem, porém, liberdade para a disposição dos direitos fundamentais do acusado. Assim, se as sanções administrativas veicularem penalidades tão gravosas quanto as criminais, apesar de rotuladas como sanções administrativas ou civis, tal como ocorre no caso da Lei ${ }^{\circ} 12.846 / 13$ - o que parece reforçado pelo cotejo analítico entre suas penalidades e os crimes previstos na Lei $\mathrm{n}^{\mathrm{o}}$ 9.605/98 -, a aplicação dos direitos e garantias constitucionais do acusado se dará de maneira muito semelhante à esfera penal, a exemplo da norma constitucional (direito/garantia) da intransmissibilidade das sanções, aplicável, igualmente, aos processos de responsabilização da Lei $n^{\circ} 12.846 / 13$ (BRASIL, 2013). ${ }^{25}$

Portanto, parece correto afirmar que referido dispositivo deve sofrer interpretação conforme a Constituição, no sentido de confirmar como possível a desconsideração da personalidade jurídica de pessoa jurídica apenas, e tão somente, para extensão aos seus sócios administradores e administradores: (i) da obrigação de reparar o dano; e, (ii) do perdimento dos bens, direitos ou valores que representem vantagem ou proveito direta ou indiretamente obtidos da infração, previstas nos art. $6^{\circ}, \S 3^{\circ}$ e art. 19, I, da Lei n ${ }^{\circ} 12.846 / 13$. As demais sanções da Lei Anticorrupção, por seu turno, estariam situadas naquilo que se pode nominar de zona proscrita de transcendência sancionadora, por força do art. 5, XLV, da Constituição de 1988 e art. $5^{\circ}$, item 3, do Pacto de San José da Costa Rica. Ademais, a transmissibilidade de tais sanções

\footnotetext{
${ }^{24}$ Sobre as peculiaridades do perdimento de bens no âmbito do Direito Sancionador, também conhecido como confisco e, no direito espanhol, como comisso, ver: REBOLLO PUIG, 2000.

${ }^{25}$ Sobre o tema, Osório (2015. p. 395) e Mello (2005. p. 45-46) são uníssonos ao reconhecer a impossibilidade de transmissão de sanções à pessoa distinta da pessoa do infrator, no âmbito do Direito Administrativo sancionatório.
} 
violaria a máxima da proporcionalidade, já na sua submáxima da adequação, ${ }^{26}$ vez que fulminaria qualquer finalidade preventiva da sanção, servindo, pelo contrário, como um estímulo a consumação de ilícitos, uma vez que o real infrator não estaria sujeito às consequências negativas da sua conduta (MELLO, 2005. p. 46).

Nada obstante, não se podem ignorar os tempos difíceis que o Brasil atravessa, onde o atropelo a direitos fundamentais dos acusados parece assumir a condição de política institucional do Estado, aparentemente sufragada por largos setores da opinião pública, a exigir ampliado compromisso daqueles que se dispõem à firme defesa da ordem constitucional. Impõe-se, inclusive, certo exercício de imaginação, a fim de garantir que, mesmo no pior cenário, no caso sejam assegurados mínimos padrões de aplicação conforme a Constituição dessa hipótese normativa de desconsideração, prescrita no art. 14 da Lei $n^{\circ} 12.846 / 13$. Isso condiciona avançar à análise dos critérios de interpretação, aplicação e os pressupostos dessa norma desconsiderativa, embora defensável a inconstitucionalidade da extensão dos efeitos às sanções previstas na Lei Anticorrupção.

6.2 Sobre a interpretação, aplicação e pressupostos da hipótese desconsiderativa da personalidade jurídica na Lei $n^{\circ} 12.846 / 13$

Nada obstante as razões acima alinhadas, se consolidado o entendimento no sentido de que o art. 14 da Lei $n^{0}$ 12.846/13 alberga hipótese constitucional de desconsideração da personalidade jurídica, para toda e qualquer sanção prevista em seu microssistema, importante descortinar seus pressupostos de aplicação. Referido dispositivo traz em sua redação um pressuposto central aliado a dois pressupostos específicos/alternativos para desconsideração da pessoa jurídica, a saber: que tenha havido utilização da pessoa jurídica com abuso do direito (pressuposto central) (i) para facilitar, encobrir ou dissimular a prática dos atos ilícitos previstos no art. $5^{\circ}$ da Lei $n^{\circ}$ 12.846/13; ou, (ii) para provocar confusão patrimonial.

Como se nota da referida norma, a princípio a disregard doctrine pode ser classificada como teoria maior, já que elenca como pressuposto o abuso do direito. Já se viu que, em contraposição à teoria maior, existem as teorias desconsiderativas menores que não pressupõem a fraude e/ou o abuso do direito para fins de desconsideração. Tais teorias exigem,

\footnotetext{
${ }^{26}$ Para um estudo panorâmico sobre a teoria dos princípios e, em especial, a máxima da proporcionalidade e suas submáximas, como a adequação, a exigibilidade e a proporcionalidade em sentido estrito, ver: CRISTÓVAM, 2016.
} 
via de regras, apenas a dificuldade no ressarcimento dos prejuízos como pressupostos para afastamento da personalidade jurídica. Cite-se como exemplo aquelas hipóteses previstas no art. $28, \S 5^{\circ}$ do Código de Defesa do Consumidor e no art. $4^{\circ}$ da Lei de Crimes e Infrações Ambientais (BRASIL, 1990; 1998).

Ao explicar o dispositivo desconsiderativo da Lei 12.846/13, Santos, Bertoncini e Custódio Filho (2014. p. 229) assinalam que também seria possível o levantamento do véu da pessoa jurídica na hipótese de "impossibilidade econômica de pagamento pela pessoa jurídica de multas ou de reparações pecuniárias, ou a ocultação e desaparecimento de bens da pessoa jurídica”. Embora respeitável o entendimento, tal hipótese não parece encontrar, nem de longe, ressonância no referido dispositivo. Aceitá-lo equivaleria a assumir inequívoca interpretação criativa ou extensiva que, se viável em outras searas do Direito, não pode ser aplicada no seio do Direito Administrativo sancionatório, submetido ao princípio da legalidade estrita, que exige interpretação restritiva das respectivas hipóteses legais.

Cumpre asseverar que a desconsideração da pessoa jurídica na Lei $\mathrm{n}^{\circ}$ 12.846/13 gravita em torno do abuso de direito, sendo essencial à compreensão do instituto a investigação dessa expressão, o que indica o socorro à definição legal de exercício abusivo de direitos, prevista no art. 187 do Código Civil (BRASIL, 2002), segundo a qual incorrerá em abuso de direito aquele que o exerce excedendo, manifestamente, os limites impostos pelo seu fim econômico ou social, ou pela boa-fé ou pelos bons costumes.

Uma definição legal cercada de termos indeterminados, abertos e plurissignificativos, o que dificulta e muito a fixação dos seus limites operativos/interpretativos/integrativos, em especial para fins de aplicação de norma jurídica sancionatória!

O problema, que parecer ser ignorado, é que a prática de qualquer um dos atos lesivos tipificados no art. $5^{\circ}$ da Lei $n^{\circ} 12.846 / 13$ pode subsumir-se ao conceito legal de abuso de direito na utilização de pessoa jurídica. Tal conclusão é inconteste e dispensa, inclusive, a técnica da reductio ad absurdum para evidenciá-la. Afinal, todos esses ilícitos são consumados, necessariamente, por meio de uma pessoa jurídica, conforme conceituação do seu art. $1^{\circ}$, parágrafo único. ${ }^{27}$ Parece viável reconhecer que a utilização de pessoa jurídica para prometer, dar ou pagar vantagem indevida a agente público; financiar atos lesivos à Administração Pública; ocultar reais interesses ou identidade dos beneficiários dos atos praticados; fraudar

\footnotetext{
${ }^{27}$ Giza-se, a propósito, que a Lei $n^{\circ} 12.846 / 13$ traz uma conceituação aparentemente esquizofrênica de pessoas jurídicas. Sua conceituação não inclui todas as pessoas jurídicas previstas no art. 44 do Código Civil, e, ao mesmo tempo, inclui como pessoas jurídicas aquilo que, rigorosamente, não é pessoa jurídica, como é o caso de sociedades não personificadas -, como se vê do art. 985 do Código Civil (BRASIL, 2002).
} 
licitações e contratos públicos ou para dificultar atividade investigativa ou fiscalizatória do Poder Público; não estariam dentro dos limites impostos à pessoa jurídica pelo seu fim econômico, social, pela boa-fé ou pelos bons costumes.

Com efeito, nada obstante o condicionamento da desconsideração ao abuso de direito, a teoria prestigiada na referida legislação também pode ser considerada, em última análise, como teoria menor, pois, na prática, se consagrada sua interpretação literal e inadvertida, alberga uma hipótese de desconsideração da personalidade jurídica ex lege. É dizer, se estiver provado que a pessoa jurídica incorreu em alguma das práticas do art. $5^{\circ}$ da Lei $\mathrm{n}^{\circ}$ 12.846/13, automaticamente, estaria atendido o pressuposto para desconsideração da pessoa jurídica do seu art. 14.

A gravidade da situação consiste, justamente, no fato de que tal dispositivo, se interpretado nos seus exatos contornos, pode ser utilizado para disfarçar sancionamento da pessoa física por responsabilidade objetiva, prática repudiada pelo sistema normativoconstitucional brasileiro. A interpretação literal do artigo conduz, simplesmente, a uma conclusão inadmissível, razão pela qual, se entendido pela sua constitucionalidade, isso reclamaria interpretação conforme a Constituição.

A premissa básica fundamental é que, na interpretação e aplicação do dispositivo, deve-se ter em mente tratar-se de instituto afeto ao Direito Administrativo sancionatório, restritivo de direitos e liberdades fundamentais. Assim, devem ser afastadas, de plano, metodologias interpretativas elásticas, criativas e/ou extensivas das suas disposições. A interpretação deve ser restritiva e obsequiosa aos direitos e garantias fundamentais proclamados na Constituição de 1988.

Aceita essa premissa, podem-se extrair três conclusões.

Primeiro, a interpretação e aplicação do dispositivo deve evitar a consagração de responsabilidade por fato de outrem, também inconstitucional por decorrência do princípio da pessoalidade ou intranscendência da pena (art. $5^{\circ}$, XLV, da CRFB). Com efeito, a desconsideração da personalidade jurídica no âmbito da Lei $\mathrm{n}^{\mathrm{o}}$ 12.846/13 exigirá que o administrador ou sócio-administrador na mira da desconsideração pretendida tenha efetivamente colaborado e/ou concorrido para a consumação do ato lesivo objeto da sanção que se lhe busca estender. Sem essa participação causal, não poderá haver desconsideração por questões de pessoalidade da pena. 
A propósito, o parágrafo 22 da exposição de motivos apresentada na proposta do anteprojeto da lei, ${ }^{28}$ subscrita por Jorge Hage Sobrinho, Tarso Fernando Herz Genro e Luis Inácio Lucena Adams, reforça essa primeira conclusão, laborando como fonte de interpretação autêntica do artigo 14, a saber:

22. O efeito previsto para desconsideração é a possibilidade de se aplicar aos sócios com poderes de administração e aos administradores da pessoa jurídica as mesmas sanções cabíveis contra ela, estendendo-se, por exemplo, a declaração de inidoneidade da empresa para as pessoas naturais envolvidas na prática dos ilícitos. (sem grifo no original)

Giza-se que, a fim de assegurar o mínimo de conformidade constitucional ao dispositivo, não parece suficiente a demonstração de uma relação causal entre abuso de direito elencado como justificativa à desconsideração e conduta imputável ao sócio-administrador e/ou ao administrador da pessoa jurídica. A relação causal deve ser verificada entre o ato lesivo previsto no art. $5^{\circ}$ da Lei Anticorrupção e pessoa física objeto da desconsideração pretendida.

Segundo, a interpretação e aplicação do dispositivo não pode redundar, na prática, em uma responsabilização objetiva do(s) sócio(s)-administrador(es) e do(s) administrador(es) da pessoa jurídica, ainda que indiretamente. Isso porque, repita-se, não há no sistema constitucional brasileiro autorização para imposição de sanções ${ }^{29}$ a pessoas físicas de maneira objetiva, independentemente de aferição da culpabilidade. Se já é questionável tal possibilidade contra pessoas jurídicas, parece não haver dúvidas que é inviável para pessoas físicas. A toda evidência, indigitada hipótese no mínimo dependeria de base constitucional expressa, o que não existe em nossa ordem constitucional. ${ }^{30}$

Terceiro, a interpretação e aplicação do dispositivo não poderá resultar na desconsideração da personalidade jurídica em desfavor de outras pessoas que não as pessoas do(s) sócio(s)-administrador(es) e do(s) administrador(es) da pessoa jurídica. Por razões de legalidade estrita, não poderá haver desconsideração para atingir sócios não administradores e

\footnotetext{
${ }^{28}$ Disponível em: <http://www.camara.gov.br/sileg/integras/1084183.pdf>. Acesso em: 19 out. 2018.

${ }^{29}$ O termo "sanção" é, aqui, utilizado encerrando a noção de um consequente normativo destinado à finalidade repressora elou punitiva, diferente, portanto, de outros consequentes normativos destinados a finalidades outras, como, por exemplo, o ressarcimento de dano. Não se desconhece, porém, que o termo sanção, etimológica e gramaticalmente, admite a ideia de uma consequência premial (não negativa). Nesse sentido, ver: REBOLLO PUIG, 2001. p. 153-154.

${ }^{30}$ Osório (2015. p. 394) comunga da mesma conclusão: "Incabível a responsabilidade objetiva, eis uma das consequências do princípio da pessoalidade da sanção administrativa. Repele-se, fundamentalmente, a responsabilidade pelo fato de outrem e a responsabilidade objetiva. O delito é obra do homem, como o é a infração administrativa praticada por pessoa física, sendo inconstitucional qualquer lei que despreze o princípio da responsabilidade subjetiva".
} 
muito menos desconsideração na modalidade expansiva para alcançar eventuais "sócios ocultos" da empresa.

Há de se observar, sobre essa terceira conclusão, que ela não enfraquece a eficiência da legislação no que tange a sua finalidade precípua de combate à corrupção. Isso porque a responsabilização de pessoas físicas (cor)responsáveis pelos atos lesivos à Administração Pública pode/deve ser feita no próprio processo administrativo de responsabilização, mediante apuração da culpabilidade das pessoas físicas acusadas, tal como demanda o art. $3^{\circ}$ e seus parágrafos da Lei $n^{0}$ 12.846/13, previamente à imposição das sanções, garantidos pleno contraditório e ampla defesa (BRASIL, 2013).

Quanto ao segundo pressuposto específico-alternativo do art. 14 (provocar confusão patrimonial), conforme visto somente poderá justificar desconsideração para fins de extensão da obrigação de reparação do dano e/ou perdimento dos bens. Fora dessas hipóteses, a desconsideração estaria, necessariamente, condicionada à observância da primeira, segunda e terceira conclusões anteriormente assentadas.

Por derradeiro, cumprem mais duas observações. Primeiro, há de se destacar o art. $4^{\circ}$ e parágrafos da Lei $n^{\circ} 12.846 / 13$ que prescrevem, resumidamente, a (i) responsabilidade subsidiária da sucessora da pessoa jurídica acusada/sancionada; e, (ii) a responsabilidade solidária das sociedades controladoras, controladas, coligadas e das consorciadas, no âmbito do respectivo contrato, pela prática dos atos previstos na referida legislação, limitada a responsabilidade, em ambos os casos, ao pagamento da multa e reparação integral do dano causado. Como se nota, é absolutamente dispensável a técnica da desconsideração da personalidade jurídica nessas hipóteses para referidos propósitos, decorrendo a (cor)responsabilidade, a princípio, por força de lei. Evidentemente, isso não descarta um exame de constitucionalidade para aferir a possibilidade de se responsabilizar subsidiária ou solidariamente tais pessoas jurídicas pela obrigação de multa (medida de cunho sancionatório), por força do próprio princípio da pessoalidade da pena. Por outro lado, parece induvidosa a constitucionalidade dessa previsão no que tange à obrigação de ressarcimento.

Segundo, impõe registrar que o legislador não previu momento específico para a realização da desconsideração da personalidade jurídica. Ela pode ser feita tanto simultaneamente à apuração do ato lesivo imputado à pessoa jurídica, quanto posteriormente, após a condenação no processo de responsabilização. No entanto, o seu exercício está, sim, sujeito à limitação temporal, sobretudo no que tange à desconsideração para finalidade de extensão de sanções administrativas às pessoas físicas, hipótese em que será aplicável o lustro 
prescricional previsto no art. 25 da Lei $\mathrm{n}^{\mathrm{o}}$ 12.846/13. Afinal, é garantia fundamental de todos os cidadãos que seus atos pretéritos um dia se tornem, efetivamente, passado. ${ }^{31}$

\section{Considerações finais}

$\mathrm{Na}$ esteira das considerações alinhadas, parece viável e mesmo imperioso defender a existência de um regime jurídico-administrativo sancionatório, vivificado pelos ventos do fenômeno de constitucionalização do Direito Administrativo. Esse regime condiciona e conforma a interpretação das normas impositivas de sanções administrativas aos direitos e garantias fundamentais vinculados ao devido processo legal, cujos conteúdos variam conforme a gravidade da sanção, sempre assegurados seus conteúdos mínimos.

Igualmente, parece inconteste que a Lei Anticorrupção perfaz-se em diploma tipicamente sancionatório submetido a esse regime jurídico especial. Com efeito, as suas medidas aflitivas são tão ou mais gravosas que aquelas previstas na Lei n ${ }^{\circ}$ 9.605/98 (Lei de Crimes e Infrações Ambientais) às pessoas jurídicas. Por conseguinte, os conteúdos dos direitos e garantias fundamentais assegurados aos acusados em geral hão de ser também muito próximos daqueles verificados no regime de responsabilidade penal das pessoas jurídicas na Lei de Crimes Ambientais.

À vista disso, esbarra na garantia fundamental da pessoalidade ou intranscendência da pena (art. 5, XLV, da CRFB c/c art. 5 , item 3 do Pacto de San José da Costa Rica), sucumbindo, portanto, ao exame de constitucionalidade/convencionalidade, a hipótese desconsiderativa da personalidade jurídica, prevista no art. 14 da Lei $n^{\circ} 12.846 / 13$, para estender a imposição de penalidades as pessoas físicas dos administradores e/ou sócios administradores. Essa hipótese somente poderia ser admitida para fins de extensão a tais pessoas da obrigação de reparação de danos e, no máximo, para extensão do perdimento de bens, isso se ignorado o efeito paralisante da proibição supralegal do Pacto de San José da Costa Rica.

Ainda assim, mesmo se vencido esse empecilho constitucional, sua hipotética aplicação deve vir rente ao mínimo de coerência e conformidade à ordem constitucional, cabendo assentar as seguintes premissas básicas: (1) a desconsideração da personalidade

\footnotetext{
${ }^{31}$ Em sentido diametralmente oposto ao que se defende, mas tratando de obrigações comerciais e civis, não de imposição de sanções, a jurisprudência do STJ entende que a técnica da desconsideração da personalidade jurídica seria direito potestativo que não se extingue pelo não uso. A esse respeito, confira-se o julgado no REsp 1.180.714/RJ. Tal entendimento não é minimamente consentâneo com o direito fundamental do acusado à segurança jurídica e, por isso, não pode ser validado na seara do Direito Administrativo sancionatório.
} 
jurídica no âmbito da Lei $\mathrm{n}^{\circ}$ 12.846/13 exigirá que o administrador ou sócio-administrador na mira da desconsideração pretendida tenha efetivamente colaborado e/ou concorrido para a consumação do ato lesivo objeto da sanção que se lhe busca estender, evitando-se, assim, a responsabilidade por fato de outrem, inconstitucional por decorrência do princípio da pessoalidade ou intranscendência da pena (art. $5^{\circ}, \mathrm{XLV}$, da CRFB); (2) além dessa participação causal, deve-se apurar se ela se deu na modalidade culposa ou dolosa, afastando-se, assim, a responsabilidade objetiva de tais pessoas físicas ao arrepio do sistema jurídico constitucional brasileiro, o que aconteceria, ainda que de maneira oblíqua, se não fosse verificado o elemento subjetivo do agente; e, (3) a desconsideração de pessoas jurídica somente poderá ser levada a efeito contra seu(s) sócio(s)-administrador(es) e/ou administrador(es), proscrita a medida contra pessoas físicas que não ostentem tal qualidade, por força do princípio da estrita legalidade.

Indispensável, pois, o respeito aos direitos e garantias fundamentais daqueles alcançados pela aplicação da Lei $\mathrm{n}^{\circ}$ 12.846/13. Afinal, o combate à corrupção jamais poderá ser adequada e validamente cumprido se à margem da ordem constitucional. Mais ainda, se essa verdadeira "cruzada" tem o potencial de comprometer, a um só tempo, o emprego de milhares de brasileiros e combalir ferozmente setores inteiros da economia nacional.

\section{Referências bibliográficas}

ALARCÓN SOTOMAYOR, Lucía. Los confines de las sanciones: en busca de La frontera entre Derecho penal y Derecho administrativo sancionador. Revista de Administración Pública, v. 195, Madrid (Espanha), p. 135-167, 2014.

BRASIL. Constituição da República Federativa do Brasil De 1988. Disponível em: $<$ http://www.planalto.gov.br/ccivil_03/constituicao/constituicao.htm>. Acesso em: 19 out. 2018.

BRASIL. Casa Civil. Decreto n 3.678, de 30 de novembro de 2000. Promulga a Convenção sobre o Combate da Corrupção de Funcionários Públicos Estrangeiros em Transações Comerciais Internacionais, concluída em Paris, em 17 de dezembro de 1997. Disponível em: $<$ http://www.planalto.gov.br/ccivil_03/decreto/d3678.htm>. Acesso em: 19 out. 2018. 
BRASIL. Casa Civil. Lei no 10.406, de 10 de janeiro de 2002.Institui o Código Civil. Disponível em: <http://www.planalto.gov.br/ccivil_03/leis/2002/110406.htm>. Acesso em: 19 out. 2018.

BRASIL. Casa Civil. Decreto n⿳ 4.410, de 07 de outubro de 2002. Promulga a Convenção Interamericana contra a Corrupção, de 29 de março de 1996, com reserva para o art. XI, parágrafo 1o, inciso "c". Disponível em: <http://www.planalto.gov.br/ccivil_03/decreto/2002/d4410.htm>. Acesso em: 19 out. 2018.

BRASIL. Casa Civil. Decreto no 5687, de 31 de janeiro de 2006. Promulga a Convenção das Nações Unidas contra a Corrupção, adotada pela Assembleia-Geral das Nações Unidas em 31 de outubro de 2003 e assinada pelo Brasil em 9 de dezembro de 2003. Disponível em: $<$ http://www.planalto.gov.br/ccivil_03/_Ato2004-2006/2006/Decreto/D5687.htm>. Acesso em: 19 out. 2018.

BRASIL. Casa Civil. Lei $\mathbf{n}^{\mathbf{0}}$ 12.846, de $1^{\mathbf{0}}$ de agosto de 2013. Disponível em: $<$ http://www. planalto.gov.br/ccivil_03/_ato2011-2014/2013/lei/112846.htm>. Acesso em: 19 out. 2018.

BRASIL. Supremo Tribunal Federal. Recurso Extraordinário 466.343. Relator Min. Cezar Peluso, Brasília, 03 de dezembro de 2008.

BARROSO. Luís Roberto. A constitucionalização do direito e suas repercussões no âmbito administrativo. In: ARAGÃO, Alexandre dos Santos; MARQUES NETO, Floriano de Azevedo (Coord.). Direito Administrativo e seus novos paradigmas. Belo Horizonte: Fórum, 2008. p. 31-63.

BINENBOJM, Gustavo. Uma teoria do direito administrativo: direitos fundamentais, democracia e constitucionalização. 2. ed. São Paulo: Renovar, 2008.

CLÁPIS, Flávia Maria de Morais Geraigire. Desconsideração da personalidade jurídica. 2006. 205 f. Dissertação (Mestrado em Direito) - Pontifícia Universidade Católica de São Paulo, Programa de Pós-Graduação em Direito, São Paulo, 2006. 
CEREZO MIR, José. Limites entre el derecho penal y el derecho administrativo. Anuario de Derecho Penal y Ciencias Penales, tomo 28, p. 159-175, 1975.

CORRÊA, Mariana Rocha. A eficácia da desconsideração expansiva da personalidade jurídica no sistema jurídico brasileiro. Artigo Científico apresentado à Escola da Magistratura do Estado do Rio de Janeiro como exigência para obtenção do título de PósGraduação. 2011. Disponível em: <http://www.emerj.tjrj.jus.br/paginas/trabalhos_conclusao /1semestre2011/trabalhos_12011/MarianaRochaCorrea.pdf>. Acesso em: 19 out. 2018.

COSTA, Helena Regina Lobo da. Direito penal econômico e direito administrativo sancionador: $n e$ bis in idem como medida política sancionadora integrada (tese de livredocência). Faculdade de Direito da Universidade de São Paulo (FDUSP), 2013.

CRISTÓVAM, José Sérgio da Silva. Administração Pública democrática e supremacia do interesse público: novo regime jurídico-administrativo e seus princípios constitucionais estruturantes. Curituba: Juruá, 2015.

CRISTÓVAM, José Sérgio da Silva. Princípios constitucionais: razoabilidade, proporcionalidade e argumentação jurídica. 2. ed. Curitiba: Juruá, 2016.

FARALDO CABANA, Patricia. Se adecua el derecho penal español al convenio de la OCDE de lucha contra la corrupción de agentes públicos extranjeros em las transacciones comerciales internacionales? Boletín del Ministério de Justicia (BMJ), ano LXV, n. 2148, Madrid, p. 1-20, 2012.

FAORO, Raymundo. Os donos do poder: formação do patronato político brasileiro. 3. ed. São Paulo: Globo, 2001.

FERREIRA, Daniel. Sanções administrativas. São Paulo: Malheiros, 2001.

JUSTEN FILHO, Marçal. Desconsideração da personalidade societária no direito brasileiro. São Paulo: Revista dos Tribunais, 1987. 
JUSTEN FILHO, Marçal. O direito administrativo de espetáculo. In: ARAGÃO, Alexandre dos Santos; MARQUES NETO, Floriano de Azevedo (Coord.). Direito Administrativo e seus novos paradigmas. Belo Horizonte: Fórum, 2008. p. 65-85.

HOLANDA, Sérgio Buarque de. Raízes do Brasil. 26 ed. São Paulo: Companhia das Letras, 1995.

MELLO, Rafael Munhoz de. Sanção administrativa e o princípio da culpabilidade. A\&C Revista de Direito Administrativo e Constitucional, Belo Horizonte, ano 5, n. 22, 2005.

MELLO, Rafael Munhoz de. Princípios constitucionais de direito administrativo sancionador. São Paulo: Malheiros, 2007.

MOHALLEM, Michael Freitas; RAGAZZO, Carlos Emmanuel Joppert. Diagnóstico institucional: primeiros passos para um plano nacional anticorrupção. Rio de Janeiro: Escola de Direito do Rio de Janeiro da Fundação Getúlio Vargas, 2017, p. 20. Disponível em: $<$ http://bibliotecadigital.fgv.br/dspace/bitstream/handle/10438/18167/Diagn\%C3\%B3stico\%2 0institucional\%20\%20reduzido.pdf?sequence=4\&isAllowed=y>. Acesso em: 19 out. 2018.

MORAES, Flávia Albertin de. A teoria da desconsideração da personalidade jurídica e o processo administrativo punitivo. Revista de Direito Administrativo, Rio de Janeiro, v. 252, 2009.

NIETO, Alejandro. Régimen sancionador de las administraciones públicas: últimas novidades. Passos recientes del processo sustantivizador del derecho adminisrativo sancionador. Cuadernos de Derecho Local, n. 14, Madrid, p. 7-13, 2007.

OLIVEIRA, Régis Fernandes de. Infrações e sanções administrativas. 2. ed. São Paulo: Revista dos Tribunais, 2005.

OSÓRIO, Fábio Medina. Direito administrativo sancionador. 5. ed. São Paulo: Revista dos Tribunais, 2015.

PEREIRA JUNIOR, Jessé Torres; DOTTI, Marinês Restelatto. A desconsideração da 
personalidade jurídica em face de impedimentos para participar de licitações e contratar com a Administração Pública: limites jurisprudenciais. Revista IOB de Direito Administrativo, v. 5, p. 79-112, 2010.

RAMINA, Larissa. Tratamento jurídico internacional da corrupção: a Convenção Interamericana contra a Corrupção da O.E.A e a Convenção sobre o Combate da Corrupção de Funcionários Públicos Estrangeiros em Transações Comerciais Internacionais da O.C.D.E. A\&C Revista de Direito Administrativo \& Constitucional (impresso), v. 11, Belo Horizonte, p. 186-198, 2003.

RAMÍREZ TORRADO, Maria Lourdes. La sanción administrativa y su diferencia com otras medidas que imponen cargas a los administrados em el contexto español. Revista de Derecho, n. 27, Barranquilla (Colombia), p. 274-275, 2007.

REBOLLO PUIG, Manuel. El contenido de las sanciones. Revista Justicia Administrativa, n. extra 1, Lex Nova: Madrid (España), p. 151-206, 2000.

RELOLLO PUIG, Manuel; IZQUIERDO CARRASCO, Manuel; ALARCÓN SOTOMAYOR, Lucía. BUENO ARMIJO, Antonio. Panorama del derecho administrativo sancionador en España. Revista Estudos Socio-Jurídicos, v. 7, n. 1, Bogotá (Colombia), p. 23-74, 2005.

SANTOS, José Anacleto Abduch; BERTONCINI, Mateus; CUSTÓDIO FILHO, Ubirajara. Comentários à Lei 12.846/2013. 1. ed. São Paulo: Revista dos Tribunais, 2014.

SOUZA, Jessé. A elite do atraso: da escravidão à Lava Jato. Rio de Janeiro: Leya, 2017.

SOUZA, Jessé. A tolice da inteligência brasileira: ou como o país se deixa manipular pela elite. São Paulo: Leya, 2015.

SUAY RINCON, José. La potestade sancionadora de la Administración y sus exigências actuales: un estudio preliminar. Revista Documentación Administrativa, n. 280-281, Madrid, p. 43-64, 2008. 
VITTA, Heraldo Garcia. A sanção no direito administrativo. Malheiros: São Paulo, 2003. 


\section{DIREITO URBANÍSTICO, CIDADE E ALTERIDADE}

\section{APRESENTAÇÃO}

Na cidade de Zaragoza, na Província de Aragon, Espanha, uma das mais tradicionais e históricas cidades espanholas, no dia 7 de setembro de 2018, realizou-se o VIII Encontro Internacional do CONPEDI.

Participaram do evento a Professora Doutora Ana Paula Basso, da Universidade Federal de Campina Grande e o Professor Doutor Edson Ricardo Saleme para coordenação do Grupo de Trabalho de Direito Urbanístico e Alteridade, na tradicional sala das juntas, da Universidade de Zaragoza, cuja equipe de decanos é liderada pelo Dr. D. Javier López Sánchez. Após a apresentação dos pesquisadores, esta publicação tornou-se possível.

O debate crítico do direito urbanístico é fundamental no Brasil, considerando-se que suas cidades possuem grande número de atribuições com orçamento extremamente reduzido em face das receitas tributárias e repasses a eles constitucionalmente outorgados. Os municípios possuem importância fundamental em todo o País, pois são células formadoras da própria Federação brasileira.

O cenário atual de regularização fundiária e de diplomas que tornaram o direito urbanístico ramo do direito público extremamente atual e dinâmico evidenciam a necessidade de se gerenciar, com planos diretores adequados, cidades que desordenadamente cresceram e onde existem numerosos grupos de pessoas de baixa-renda sem qualquer possibilidade de obtenção de teto para sua moradia. Essas circunstâncias sobrevieram graças aos gastos significativos que se tem para se implementar loteamentos nos moldes da Lei 6766/79.

A partir desses cenários atuais, Pedro Dias de Araújo Júnior propôs debate sobre os núcleos urbanos informais consolidados à luz da sociologia jurídica como um dos elementos de interpretação do novo marco legal de regularização fundiária. Com fundamento em Luhmann, o artigo analisou a dupla contingência de se viver em adensamentos urbanos paralegais e o direito à moradia. 
Outro trabalho apresentado pelo pesquisador Zedequias de Oliveira Júnior, bem esclareceu como a hermenêutica jurídica poderia auxiliar no desenvolvimento e implementação de políticas públicas urbano-ambientais em prol da coletividade, especialmente para proteção das áreas de preservação permanente. Afirmou que esta análise deve estar moldada em ação e colaboração da União, estados e municípios, conjunta ou separadamente. Isso sem se olvidar do uso da ferramenta do planejamento espacial.

Os trabalhos transcorreram com muitas discussões frutíferas e logrou-se espaço para profícuas conclusões e propostas de soluções diante da complexa situação das cidades brasileiras.

Por fim, há que registrar que os autores que apresentaram suas pesquisas no "GT Direito urbanístico, cidade e alteridade", não se restringiram a tecer críticas sobre a situação objeto de análise, mas também propuseram respostas aos problemas que constataram. Por esta razão cabe destacar a importância da leitura e profusão destes textos que é feita pelo CONPEDI, de forma que proporcione maior conscientização e instrumentalização de melhor organização e preservação do meio ambiente urbano e natural.

Coordenadores do GT:

Prof. Dr. Edson Ricardo Saleme (UNIVERSIDADE CATÓLICA DE SANTOS)

Prof $^{a}$. Dr ${ }^{\mathrm{a}}$. Ana Paula Basso (UNIVERSIDADE FEDERAL DE CAMPINA GRANDE) 


\title{
NOVA PERSPECTIVA DA HERMENÊUTICA JURÍDICA NA \\ INSTRUMENTALIZAÇÃO DA PROTEÇÃO DAS ÁREAS DE PRESERVAÇÃO \\ PERMANENTE DOS ESPAÇOS URBANOS
}

\section{Zedequias de Oliveira Júnior}

Universidade Federal de Roraima e Ministério Público de Roraima

\begin{abstract}
Resumo
O desenvolvimento e implementação de políticas públicas urbano-ambientais em prol da coletividade, especialmente para proteção das áreas de preservação permanente, tem apoio singular na hermenêutica jurídica para sua efetivação. Este desiderato, para ser alcançado, deve estar moldado em ação e colaboração da União, dos estados e dos municípios, conjunta ou separadamente, além da concepção de ser prioritário o uso da ferramenta do planejamento espacial. A representatividade e legitimidade deste processo, contudo, só serão reconhecidas quando houver a participação da sociedade que tem direito de viver num ambiente saudável.
\end{abstract}

Palavras-chave: Proteção, áreas de preservação permanente, hermenêutica, planejamento, espaço urbano.

\section{Abstract/Resumen/Résumé}

The development and implementation of urban-environmental public policies for the benefit of the community, especially for the protection of permanent preservation areas, has singular support in legal hermeneutics for its effectiveness. This aim, to be achieved, must be shaped in action and collaboration of the Union, the states and the municipalities, jointly or separately, besides the conception of being a priority the use of the spatial planning tool. The representativeness and legitimacy of this process, however, will only be recognized when there is the participation of the society that has the right to live in a healthy environment.

Keywords/Palabras-claves/Mots-clés: Protection, areas of permanent preservation, hermeneutics, planning, urban space. 


\section{Introdução}

O presente estudo pretende avaliar o papel da hermenêutica jurídica para propiciar os mecanismos mais abalizados e aptos a proporcionar a devida e constitucional proteção das Áreas de Preservação Permanente (APP) existentes no ambiente urbano, sejam elas instituídas por lei e mesmo àquelas que são e as que poderão ser criadas por ato do chefe do executivo.

A fim de viabilizar uma análise coerente, necessário se fez esclarecer que, apesar da configuração das APP's como espaços territoriais especialmente protegidos, conforme art. 225, $\S 1^{\circ}$, III, da Constituição da República Federativa do Brasil - CRFB de 1988 (BRASIL, 1988), existem inúmeras possibilidades legais que admitem intervenção e supressão da vegetação, situação esta que fragiliza aludido instituto ambiental, especialmente quando ocorrem no meio urbano.

Conquanto, mereceu destaque a responsabilidade multifacetada do poder público, nos três níveis de governo, conjunta ou separadamente, com ênfase para o municipal que é quem exerce, no plano local, a política de ordenamento espacial das cidades para concretizar o predicado fundamental da dignidade da pessoa humana (art. $1^{\circ}$, III) e o direito social à moradia (art. $6^{\circ}$, caput) com qualidade de vida (art. 225, caput, da CRFB/1988).

O planejamento urbano, por seu turno, é elemento essencial que encontra no plano diretor uma das principais ferramentas de operacionalização, o qual só terá representatividade e legitimidade com a incondicional intervenção da sociedade em seu processo de construção.

Qualquer resultado, no entanto, seria limitado se não forem sopesadas questões umbilicais envolvendo a tratativa do tema urbano com o viés ambiental. Esta assertiva encontra ressonância no fato da antropização dos espaços urbanos só ocorrerem sobre ambientes dantes naturais, razão pela qual o desafio que se impõe é o de correlacionar tais matérias sem haver sobreposição ou exclusão, ao contrário, é imperioso indicar os meios cogentes que possam compactuar as necessidades humanas no contexto municipal urbano com a obrigatória proteção da biodiversidade, inclusive em benefício do próprio homem.

Não pode, portanto, haver dissociação entre o urbano e o ambiente natural, especialmente quando se aborda a forma com que deverá haver o planejamento da cidade. Neste quadrante, a hermenêutica, com amparo do método científico dedutivo e descritivo e uso de recursos lógico-discursivos que envolveram levantamento, revisão e pesquisa bibliográfica e normativa pode, deveras, contribuir para alicerçar os fundamentos para que os agentes públicos responsáveis possam desenvolver as mais condizentes políticas públicas capazes de contribuir para a satisfação e bem-estar das pessoas e, inclusive, sem preterição dos valores que justificam a existência das APP's. 


\section{2. Áreas de preservação permanente, por força de lei e ato do chefe do executivo, e as exceções que admitem intervenção e supressão no cenário urbano}

Com o intuito de explorar a temática proposta e alcançar os resultados pretendidos, necessário é adentrar na hermenêutica jurídica que possibilitará, a partir da interpretação coerente da legislação correlata, sopesar os mecanismos apropriados para proporcionar a proteção das APP's levando em conta o crescimento populacional nos espaços urbanos.

Desta forma, na qualidade de espaço territorial especialmente protegido expressamente previsto no art. 225, §1 $1^{\circ}$, III, da Constituição da República Federativa do Brasil de 1988 (BRASIL, 1998), a Área de Preservação Permanente (APP) teve sua primeira definição alavancada pela Medida Provisória $n^{\circ}$ 1.956-50, de 26.05.2000 (BRASIL, 2000), a qual alterou o art. $1^{\circ}$ da Lei $\mathrm{n}^{\circ}$ 4.771, de 15.09.1965 (BRASIL, 1965) e mantida até a última Medida Provisória $\mathrm{n}^{\mathrm{o}}$ 2.166-67, de 24.08.2001 (BRASIL, 2001), praticamente repetida pela vigente Lei $\mathrm{n}^{\mathrm{o}}$ 12.651, de 25.05.2012 (BRASIL, 2012).

A APP configura, assim, a "área protegida, coberta ou não por vegetação nativa, com a função ambiental de preservar os recursos hídricos, a paisagem, a estabilidade geológica e a biodiversidade, facilitar o fluxo gênico de fauna e flora, proteger o solo e assegurar o bem-estar das populações humanas" (BRASIL, 2012, art. $3^{\circ}$, II). Podem ser divididas em 02 (duas) partes: a) constantes do art. $4^{\circ}$, com 15 (quinze) exemplos; e b) ato do Poder Executivo, conforme art. $6^{\circ}$, com 16 (dezesseis) exemplos.

As seguintes hipóteses, ex vi legis da Lei $\mathrm{n}^{\mathrm{o}}$ 12.651/2012, denominada novo Código Florestal, Código da Flora ou Código de Proteção da Vegetação Nativa, envolvem as faixas marginais de qualquer curso d'água natural perene e intermitente, excluídos os efêmeros (art. $\left.4^{\mathrm{o}}, \mathrm{I}\right)$; bem como as áreas do entorno de lagos e lagoas somente naturais superiores a um hectare (art. $4^{\circ}, \mathrm{II}, \mathrm{e} \S^{\circ}$ ); as áreas que contornam os lagos e lagoas artificiais oriundos de cursos d'água naturais superiores a um hectare (art. $4^{\circ}, \mathrm{III}, \S 1^{\circ}$ e $\left.\S 4^{\circ}\right)$; as áreas ao redor de nascentes e olhos d'água perenes (art. $\left.4^{\circ}, \mathrm{IV}\right)$; as encostas ou partes com declividade superior a $45^{\circ}\left(\operatorname{art} .4^{\circ}, \mathrm{V}\right)$; as restingas (art. $\left.4^{\circ}, \mathrm{VI}\right)$; os manguezais (art. $4^{\circ}$, VII); as bordas dos tabuleiros ou chapadas (art. $4^{\mathrm{o}}$, VIII); os topos de morros, montes, montanhas e serras (art. $\left.4^{\circ}, \mathrm{IX}\right)$; as áreas em altitude superior a 1.800 metros $\left(\operatorname{art} .4^{\circ}, \mathrm{X}\right)$; e as veredas (art. $\left.4^{\circ}, \mathrm{XI}\right)$.

Além destas, nos termos do artigo $6^{\circ}$ da mencionada norma, encontram-se as que poderão ser instituídas por ato do Chefe do Poder Executivo, desde que seja evidenciado o interesse social e estejam ou não cobertas por florestas ou outras formas de vegetação. Todavia 
é compulsório que qualquer delas estejam justificadas, isolada ou conjuntamente, para conter a erosão do solo e mitigar riscos de enchentes e deslizamentos (I); para proteger as restingas(II), veredas(II) ou várzeas(III); para abrigar exemplares da fauna ou flora ameaçados de extinção(IV); para proteger sítios de excepcional beleza ou valor científico, cultural ou histórico(V); para formar faixas de proteção ao longo de rodovias e ferrovias(VI); para assegurar condições de bem-estar público(VII); para auxiliar a defesa do território nacional(VIII); e/ou para proteger áreas úmidas de especial importância internacional(IX).

Estas hipóteses são, hodiernamente, o que pode ser entendido por APP's, rol este que, como visto, poderá ser ampliado, observando-se que a proteção açambarca a área que tenha ou não qualquer forma de vegetação nativa, porém as que tiverem, por si só, já são consideradas "bens de interesse comum a todos os habitantes do País" (art. 2º caput).

O raio de incidência das APP's envolve tanto o ambiente rural quanto o urbano e, apesar de trazer limitações e seu conteúdo implicar em restrições em nome da coletividade, não afeta o direito de propriedade de pessoa física e/ou jurídica, privada ou pública (OLIVEIRA JÚNIOR, 2014, p. 6, 60, 123/124). Ao contrário, admite a possibilidade até de posse e ocupação a qualquer título (art. $7^{\circ}$, caput).

Feita esta prefacial abordagem, verifica-se que a melhor forma de compreender o alcance das APP's é por intermédio da avaliação dos casos que poderiam admitir, em havendo vegetação nativa, retirada, alteração, intervenção ou supressão. Para tanto, o art. $8^{\circ}$ da Lei $n^{\circ}$ 12.651/2012 discrimina, expressamente, as exceções quando restar comprovada a utilidade pública, o interesse social ou ser caracterizada como de baixo impacto ambiental.

No entanto, avaliando as questões atinentes exclusivamente ao espaço urbano, podemos extrair as seguintes situações passíveis de serem autorizadas, mas que, naturalmente, são ou deveriam ser excepcionais e, evidentemente, com o devido, antecedente e incondicional aval do órgão ambiental responsável e integrante do SISNAMA (BRASIL, 1981, art. $6^{\circ}$ ). Desta forma, são consideradas, para fins de utilidade pública (art. $3^{\circ}$, VIII, e art. $8^{\circ}, \S 1^{\circ}$, da Lei $n^{\circ}$ 12.651/2012), a intervenção e supressão em vegetação nativa protetora de nascentes, dunas e restingas; para atividades de segurança nacional, proteção sanitária, obras de infraestrutura de concessões e serviços públicos de transporte, sistema viário, parcelamentos de solo urbano, saneamento, gestão de resíduos, energia, telecomunicações, radiodifusão, instalações para competições esportivas (estaduais, nacionais ou internacionais) e mineração (exceto de areia, argila, saibro e cascalho); para atividades e obras de defesa civil e que proporcionem melhorias na proteção das funções ambientais das APP's e, ainda, outras similares definidas pelo Chefe do Poder Executivo federal. 
No mesmo sentido, é possível para fins de interesse social (art. $3^{\circ}$, IX, da Lei ${ }^{\circ}$ 12.651/2012) para atividades imprescindíveis à proteção da integridade da vegetação nativa; exploração agroflorestal sustentável em pequena propriedade ou posse rural familiar ou por comunidades tradicionais; para implantação de infraestrutura pública de esportes, lazer e atividades educacionais e culturais; regularização fundiária de assentamentos humanos ocupados predominantemente por população de baixa renda em áreas urbanas consolidadas; para implantação de instalações necessárias à captação e condução de água e de efluentes tratados; para atividades de pesquisa e extração de areia, argila, saibro e cascalho e, ainda, outras similares definidas em ato do Chefe do Poder Executivo federal.

São consideradas, ademais, atividades eventuais ou de baixo impacto ambiental (art. $3^{\circ}, \mathrm{X}$, e art. $9^{\circ}$ ), a abertura de pequenas vias de acesso interno, pontes e pontilhões; o acesso de pessoas e animais para a obtenção de água ou retirada de produtos de manejo agroflorestal sustentável; a implantação de instalações para captação e condução de água e efluentes tratados e de trilhas de ecoturismo; a construção de rampa para barcos e pequeno ancoradouro e de moradia de agricultores familiares, remanescentes de comunidades quilombolas e outras populações extrativistas e tradicionais em áreas rurais, bem como de cercas; a realização de pesquisa científica sobre recursos ambientais e coleta de produtos não madeireiros para subsistência e produção de mudas; o plantio de espécies nativas produtoras de frutos, sementes, castanhas e outros; a exploração agroflorestal e manejo florestal sustentável e, ainda, outras ações ou atividades similares reconhecidas pelo Conselho Nacional do Meio Ambiente CONAMA ou Conselhos Estaduais de Meio Ambiente.

Além destas, acrescente-se, nos termos do art. $8^{\circ}, \S 2^{\circ}$, quando houver comprometimento da função ecológica do manguezal, para execução de obras habitacionais e de urbanização em projetos de regularização fundiária de interesse social, em áreas urbanas consolidadas ocupadas por população de baixa renda; e também, inclusive sem qualquer tipo de autorização ou aprovação, nos casos de urgência para execução de atividades de segurança nacional e obras de interesse da defesa civil destinadas à prevenção e mitigação de acidentes em áreas urbanas $\left(\operatorname{art.} 8^{\circ}, \S^{\circ}\right)$.

Existem, assim, inúmeras hipóteses de admissão da supressão e intervenção em APP, sendo 20(vinte) casos de utilidade pública e 12(doze) de interesse social, cujo rol pode ser ampliado, sem qualquer limite, por ato do Chefe do Executivo nacional e, igualmente, 18(dezoito) casos considerados expressamente como atividades eventuais ou de baixo impacto ambiental que, ademais, podem ser acrescentados por ato do CONAMA e dos órgãos ambientais estaduais, isto sem contabilizar, por exemplo, a permissão irrestrita, pois não indica 
como, quando, onde e de que forma poderia ocorrer, para o acesso de pessoas e animais para obtenção de água previsto no art. $9^{\circ}$.

Não obstante, é certeiro afirmar que se houver violação às regras protetivas e de natureza real indeclinável exsurge a configuração como uso irregular da propriedade, aplicando-se o procedimento sumário cível e a tríplice responsabilização estatal (civil, administrativa e penal), cujo ônus pode ser transmissível ao sucessor, de qualquer natureza, conforme art. $2^{\circ}$ do Código da Flora e art. $225, \S 3^{\circ}$, da CRFB/1988, sem prejuízo da obrigação de recompor a vegetação $\left(\operatorname{art} .7^{\circ}\right)$.

O contexto de "preservação" inserta na nomenclatura de APP, a qual incutiria maior proteção e integralidade, diverso da conservação que admite e estimula o uso sustentável, foi extremamente mitigado atualmente em função de terem sido criadas inúmeras situações ditas excepcionais que autorizariam sua modificação e, sobremodo, cerceia o comando protetivo que se buscava concretizar.

Esta novel realidade normativa, entrementes, deve ser combatida adequadamente, especialmente no ambiente urbano, com o desiderato de poder garantir um mínimo exigível de tutela que efetivamente justifique todos os atributos inseridos na definição legal acima destacada do art. $3^{\circ}$, II, da Lei $\mathrm{n}^{\circ} 12.651 / 2012$ e possa, em contrapartida, propiciar melhores condições de vida para as pessoas neste espaço adensado. É tão relevante a discussão e busca de soluções que Bueno (2012, p. 101/102), ao citar o UNEP Annual Report 2004 do Programa das Nações Unidas para o Meio Ambiente (PNUMA), aponta como um dos principais problemas causadores de risco à vida os relacionados à extinção de ambientes naturais decorrentes da expansão da ocupação humana nas cidades.

É por isto que a "gestão ambiental urbana de caráter antecipativa-preventiva vem assumindo cada vez mais o centro dos interesses quando se pensa nas perspectivas de alcance de um equacionamento do dilema desenvolvimento urbano/conservação do ecossistema urbano" (MENEZES, 2014, p. 24) e as APP's fazem parte deste incomensurável contexto.

\section{Responsabilidade multifacetada do poder público e planejamento urbano}

O Estado, no sentido lato, cuja representatividade está o poder público, é o principal responsável por assegurar a compatibilidade entre o urbano e o ambiental natural em benefício de todos, isto porque, conforme Azevedo (1999, p. 39), é o “ente político por excelência, ao 
qual cabe a determinação dos objetivos fundamentais, tendentes à ordenação e coordenação dos objetivos societários fundamentais".

A missão de adotar mecanismos hábeis, técnicos e qualificados para poder atingir este ideal sustentável urbano, parte, inicialmente, então, do próprio poder público, consideração todos os entes federados e poderes constituídos, em igualdade de condições. A exigência constitucional neste sentido é expressa (art. 23, IX e X, da CRFB), seja para "promover programas de construção de moradias e a melhoria das condições habitacionais e de saneamento básico" seja para "combater as causas da pobreza e os fatores de marginalização, promovendo a integração social dos setores desfavorecidos", e legislar sobre direito urbanístico (art. 24, I, c/c art. 30, I e II, da CRFB).

Nesta ordem, acrescente-se a premissa fundamental de garantir a dignidade da pessoa humana (art. $1^{\circ}$, III) e o direito social à moradia (art. $6^{\circ}$, caput) com qualidade de vida (art. 225, caput, da CRFB/1988), o que vale para o meio urbano.

Especialização temática se percebe no que adstringe às regiões metropolitanas, aglomerações urbanas e microrregiões que são constituídas por agrupamentos de municípios limí trofes, cuja responsabilidade de instituí-las é dos estados-membros, assim como para integrar a organização, o planejamento e a execução de funções públicas de interesse comum (art. $25, \S 1^{\circ}$, da CRFB); porém, como não poderia deixar de ser, é premente ouvir os municípios afetados ou que serão.

Os Estados devem ater-se ao Estatuto da Metrópole regulado pela Lei n ${ }^{\circ} 13.089 / 2015$ (BRASIL, 2015) para viabilizar a governança interfederativa das regiões metropolitanas e das aglomerações urbanas, inclusive com respeito ao princípio do desenvolvimento sustentável (art. $6^{\circ}$, VII) e elaboração e observância a diretrizes específicas e instrumentos de compensação por serviços ambientais proporcionados por cada município (art. $7^{\circ}, \mathrm{VII}$, e art. $9^{\circ}$, IX). É mister, igualmente, contar com plano de desenvolvimento urbano integrado com previsão de revisão a cada 10 anos (arts. 10 e 11), isto sem excluir a obrigatoriedade do Município integrante ter seu respectivo plano diretor. Referido plano deve conter, especialmente, o macrozoneamento da unidade territorial urbana, as diretrizes do parcelamento, uso e ocupação no solo urbano e a “delimitação das áreas com restrições à urbanização visando à proteção do patrimônio ambiental ou cultural, bem como das áreas sujeitas a controle especial pelo risco de desastres naturais, se existirem"(art. 12).

Independente de ser região metropolitana, aglomerações urbanas e microrregiões ou mesmo um único município tomado individualmente, conflitos urbanos existem e devem ser dirimidos pelo poder público. Gabardo (2011, p. 52) bem explana a respeito 


\begin{abstract}
Na discussão sobre a existência de centros e periferias fica clara a disputa entre um e outra, mas o fato é que a maioria das cidades desde os tempos mais antigos têm sua estruturação espacial caracterizada pela formação de um centro principal e, com o passar do tempo, por bairros ligados a ele direta ou indiretamente. Só recentemente, a partir do grande crescimento das cidades industriais, foram aparecendo os subcentros, ou centros de bairros. As cidades do passado remoto apresentavam uma unidade espacial formada por uma única aglomeração central onde se desenvolviam todas as atividades de comércio e habitação. Com o passar do tempo essa estrutura foi se rompendo até que o zoneamento passou a compor a formação das cidades, determinando áreas com atividades específicas compatíveis com sua função.
\end{abstract}

Afora a responsabilidade da União e dos estados-membros, são os Municípios, entes federativos de terceiro grau (NOVELINO, 2012, p. 769), os maiores atores neste processo de ordenação urbana, conforme estatui os incisos IV e VIII do art. 30 da Carta Constitucional de 1988, ao dotá-los da competência de criar, organizar e suprimir distritos e, principalmente, o de "promover, no que couber, adequado ordenamento territorial, mediante planejamento e controle do uso, do parcelamento e da ocupação do solo urbano". A missão do município está melhor delineada, no entanto, no art. 182, capítulo II, Da Política Urbana, título VII, Da Ordem Econômica e Financeira, da Constituição vigente, a quem cabe garantir o "pleno desenvolvimento das funções sociais da cidade e garantir o bem-estar de seus habitantes".

O pressuposto constitucional já dá os elementos básicos para se conquistar este tal "ordenamento urbano" quando indica o planejamento e o controle do uso do solo, ressaltando o primeiro, pois o segundo engloba o poder de polícia já inerente às atividades do poder público. Nesta linha, Terence (2002, p. 10), afirma que planejamento é o desenvolvimento de programa para a realização de objetivos e metas que possibilite escolhas e "decisão antecipada do que deve ser feito, a determinação de quando e como a ação deve ser realizada" e, por conseguinte, corporifica um mecanismo de suma importância e sem o qual não há sequer que tratar de desenvolvimento nacional equilibrado (art. 174, caput, e $\S 1^{\circ}$, da CRFB/1988).

Molda-se num verdadeiro instrumento de política urbana diretamente previsto no art. $2^{\circ}$, IV e VI, do Estatuto da Cidade (BRASIL, 2001) e princípio da política nacional do meio ambiente, nos termos do art. $2^{\circ}$, III, da Lei $n^{\circ} 6.938 / 81$ (BRASIL, 1981) e é um ponto demasiado relevante para qualquer tomador de decisão municipal na área urbana e ambiental o de envidar esforços para promover o planejamento, o qual, inclusive, conforme Santos (2009, p. 107), pode influenciar o mercado e ser capaz de diminuir a distância entre cidade econômica e a social.

Porém, todos estes predicados devem ser vistos no Plano Diretor por ser o “instrumento básico da política de desenvolvimento e de expansão urbana” e obrigatório para cidades com mais de 20.000 habitantes (art. 182, $1^{\circ}$, da CRFB/1988), cuja regulamentação 
está inserta no art. 39 e seguintes da Lei n 10.257/2001(Estatuto da Cidade), a qual esmiuça as diretrizes gerais em "nível nacional para a política urbana a ser cumprida pelos Municípios" (MUKAI, 2007, p. 72). Aludida norma geral não é autoaplicável (MILARÉ, 2009, p. 547), o que impulsiona o grande desafio atual, que não se pode negligenciar, do Município, via dos seus representantes legais, adotar todos os instrumentos para concretizar suas qualificadas propostas reconhecidas internacionalmente em prol da coletividade.

Matos (2001, p. 131/132) afirma a necessidade de se lançar uma ação local que seja apta para implementar a legislação ambiental e realizar política municipal de proteção com apoio em mecanismos que "permitirão uma redução dos problemas ambientais em nível regional e, por extensão, em nível nacional”. Para Pinto (2011, p. 95/96, 105), o “direito urbanístico sempre foi considerado uma competência essencialmente local" por meio de "leis sobre zoneamento, alinhamento, loteamento e código de obras".

No mesmo sentido está Costa (2012, p. 269), ao asseverar que a "ordenação do solo é matéria de interesse local do Município que, através do seu poder de polícia, exerce este controle com medidas prescritas" que evitem "distorções que tragam prejuízo à coletividade". Ackel Filho (1992, p. 46) pontua que

O ordenamento territorial visa à disciplina da ocupação urbana e das atividades que se desenvolvem no espaço do Município para que a urbe possa constituir um todo harmônico propiciante de bem-estar aos munícipes. Assim é da competência municipal a fixação das diretrizes básicas pertinentes ao desenvolvimento do território do Município.

O plano diretor pode ser entendido como o "complexo de normas legais, contendo diretrizes, objetivos, programas e metas, que abrangem o desenvolvimento econômico-social, o meio ambiente e o uso e ocupação do solo, projetados todos para um determinado período de tempo" (MUKAI, 2007, p. 35) e, por assim dizer, representa o caminho para perseguir o "pleno desenvolvimento das funções da cidade e da propriedade" (VICHI, 2011, p. 101) que não pode ocorrer sem haver uma gestão participativa da sociedade e respeito ao meio ambiente natural e cultural (BRASIL, 2001, art. $2^{\circ}$, II, XII). É a verdadeira operacionalização do planejamento socioespacial e ambiental.

Bueno $(2012$, p. 113, 116) enfatiza prever o Estatuto da Cidade a cidade sustentável social e ambientalmente e que o plano diretor "precisa conter uma visão do futuro" no sentido da população reconhecer e se identificar, bem como ter objetivos e metas viáveis em período de tempo pré-determinado e uma "estrutura institucional de planejamento". 
A previsão de "plano", no plano diretor, indica seu fundamento no planejamento, isto porque, conforme Silva (2006, p. 126/127) compreende os objetivos, o prazo de cumprimento, o que precisa ser executado e quem é o responsável. Sua acepção de "diretor" indica um norte, um parâmetro, um referencial que necessariamente precisa ser seguido e atendido em prol do desenvolvimento urbano que, por consequência, agiria em benefício das pessoas e do meio ambiente ao criar as bases e "condições de gestão do solo e de recursos naturais, e a qualidade política do processo de planejamento e gestão municipal” (FERNANDES, 2006).

Oliveira Júnior (2014, p. 96) consigna que das "leis municipais infra Lei Orgânica Municipal, a mais relevante é o Plano Diretor, instrumento que capacita e impulsiona o regramento organizado e amplo do que deve ser a cidade e a sua forma de crescimento conjuntural", que é reconhecido por Ackel Filho (1992, p. 259) como "espinha dorsal do desenvolvimento do Município" e, para Oliveira (2002, p. 107), a "lei básica da cidade para o desenvolvimento adequado e justo, em busca de uma cidade democrática e aberta ao povo".

A construção do modelo do que vem a ser o plano diretor, além do respaldo legal federal, conforme Oliveira Júnior (2014, p. 96), ultrapassa a liberdade do município de legislar assuntos de interesse local (art. 30, I, da CRFB/1988) para adequar-se, também, às premissas ditadas pelos estados-membros e União (art. 30, I, da CRFB/1988) e acrescenta

[...] desde que observadas as bases legais do Estado e União, verifica-se que a Associação Brasileira de Normas Técnicas editou a norma técnica NBR 12.267 sobre sua elaboração, bem como há a Resolução n²34, de $1^{\circ}$ de julho de 2005, do Conselho das Cidades que dispôs sobre seu conteúdo mínimo. Estas normativas, apesar de não serem leis em sentido estrito de cunho federal, servem de base para que os Municípios venham, com o devido aval técnico qualificado e requisitos neles incorporados, a atender ao comando constitucional e do Estatuto da Cidade, sem prejuízo da liberdade de positivar as peculiaridades inerentes a cada realidade.

A NBR 12.267, elaborada em fevereiro de 1991, com nova versão em abril de 1992 , prevaleceu até outubro de 2012 quando foi cancelada sem substituição, conforme edital $\mathrm{n}^{\circ}$ 09:2013 da ABNT(2013), o que torna vazio o dito referencial. Conquanto, existe a Resolução Recomendada $n^{\circ} 34$, de 01 de julho de 2005, alterada pela Resolução Recomendada $n^{\circ} 164$ de 26 de março de 2014, publicada no DOU de 14/07/2005, seção 1, pág. 89 e DOU de 20/10/2014, seção 1, pag. 64 (CIDADES, 2005), na qual o Conselho das Cidades, levando em conta posicionamento do Comitê Técnico de Planejamento Territorial Urbano e considerando que a elaboração dos planos diretores municipais tendem a promover o pleno desenvolvimento das funções sociais da cidade e da propriedade com propósito no bem coletivo, segurança e bem- 
estar dos cidadãos e o que considerou o equilíbrio ambiental, resolveu emitir orientações e recomendações para a construção do seu conteúdo mínimo.

Mas não se pode ter em mente que o abstrato, ideal, imaginado espaço urbano ambientalmente adequado e que respeite às APP's possa ser concretizado sem gravames e obstáculos, isto porque a teoria é muito fácil de ser ditada e a prática é complexa de ser executada, mormente quando há conflito de interesses, como entre o ambiental e moradia, o urbano e o ambiental e deste como o socioeconômico. Schussel (2011, p. 41/42) exemplifica

\begin{abstract}
No caso dos planos de zoneamento da cidade, a inflexibilidade da legislação de uso do solo urbano estimula o seu descumprimento, restringe as alternativas de uso para os pequenos investidores, além de incentivar a ocupação das áreas mais frágeis do ponto de vista ambiental pelas camadas pobres da população, que vivem em condições precárias, sem assistência do poder público, sob a justificativa da ilegalidade de sua situação, gerando uma circularidade da situação. Esse quadro, bem característico das condições sociais do país mostra a defasagem entre a cidade que a legislação pretende regular e a cidade resultante desse modelo de planejamento, e ilustra a necessidade de revisão dos paradigmas urbanísticos adotados no planejamento brasileiro $\mathrm{O}$ novo paradigma a ser construído terá que incorporar idéias-força relacionadas à complexibilidade, ao pluralismo, à sustentabilidade e à participação popular, para se aproximar da realidade urbana.
\end{abstract}

Somasse a este quadro preocupante, conforme Menezes (2004, p. 13, 24), o "alto grau de dificuldade em reformularmos a atual governança ambiental urbana" que se circunscreve a "ações reativas/curativas", ou seja, paliativas e nunca resolutivas que são "resultado das contradições dos modelos de desenvolvimento econômico e de gerência político-administrativa do Estado, adotadas nas últimas décadas".

Apar destas constatações, é conclusivo afirmar que, entre os prós e contras, a omissão é o pior dos transtornos e o instrumento mais condizente para oposição é realmente promover um planejamento urbano-ambiental elaborado por meio de equipe interdisciplinar qualificada e compulsória intervenção da sociedade, situação que poderá reduzir de modo significativo toda e qualquer inconsistência ou impropriedade.

\title{
4. Indissociedade entre o urbano e o ambiental natural como resultado da hermenêutica em matéria de áreas de preservação permanente
}

Para se trabalhar a inter-relação do urbano com o ambiental natural é preciso averiguar a cidade em sua concepção real e não hipotética ou virtual, com todas as suas interfaces, problemas, dramas, potencialidades e complexidades. Por isto, não há como dissociar o urbano do natural e cuja solução é urgente, sob pena do agravamento das consequências representa a 
cumulação de irreversibilidades. As grandes cidades brasileiras, id est, estão passando por uma profunda crise de degradação socioambiental e a

[...] política ambiental urbana, desde sua emergência até o momento não tem conseguido controlar os efeitos deletérios inerentes ao ritmo de urbanização acelerada. Tampouco tem contribuído para prevenir o aumento dos problemas socioambientais e para solucionar os já existentes. Prisioneiro na sua própria teia de estruturação jurídico-institucional afim, o Estado não tem conseguido transformar o seu modelo reativo/remedial de gestão urbana em um modelo pró-ativo/antecipativo-preventivo. (MENEZES, 2014, p. 13)

Comentado descompasso causador de crise no cenário urbano e, principalmente, ambiental é fruto do produto social denominado por Bueno(2012, p. 103) cidade contemporânea, exatamente por envolver "diferentes interesses políticos, articulados a interesses sociais e econômicos, a diversos grupos sociais detentores de poderes e interesses".

Assim, partindo da premissa do parâmetro não ser utópico e, sim, paupável e perceptível para construção e reconstrução do espaço urbano, a hermenêutica pode, deveras, na condição e ferramenta qualificada para o intérprete que com poder de decisão, auxiliar na busca do escopo constitucional inserto no art. 182 de "ordenar o pleno desenvolvimento das funções sociais da cidade e garantir o bem-estar de seus habitantes".

A razão de ser é porque a hermenêutica é reconhecida como a teoria geral da interpretação ao universalizar o método de compreensão (BRITO, 2007). Stefani e Cignachi (2013, p. 170) informam, de forma diversa, mas complementar, ser "responsável pelo estudo da teoria da interpretação, e tudo o que há no processo interpretativo, sendo capaz de estabelecer os princípios gerais de toda e qualquer compreensão".

Lixa (2013, p. 214), sobre a hermenêutica aplicada ao direito e a adequada interpretação da norma jurídica, destaca que é preciso utilizar a "racionalidade cognitivainstrumental específica" com objetivo de avaliar os fundamentos, a validade e os limites da norma a ser aplicada como "paradigma epistemológico".

Ao comentar sobre a norma fundamental do país, Stefani e Cignachi (2013, p. 174) ratificam o posicionamento no sentido de que os princípios da interpretação "servem como um guia para que o intérprete possa buscar aquela interpretação que melhor se adapte à realidade e à justiça”. Deve-se, para tanto, partir do abstrato normativo para a hipótese real a ser esquadrinhada com a nítida pretensão "não somente aferir o sentido do texto normativo, e sim aperfeiçoá-lo, para que haja uma maior efetividade à luz dos problemas concretos”.

Sob esta novel proposta que incute uma consentânea reordenação principiológica, contextual e interpretativa, Azevedo (1999, p. 31) aduz ser fundamental que os operadores 
jurídicos "sejam capazes de perceber e obviar as insuficiências do direito positivo, ao invés de deixá-las à conta e responsabilidade exclusiva do legislador" por não bastar ter norma (FREITAS, 2005, p. 8).

A correlação entre o urbano e o ambiental, neste diapasão, é um fato incontestável e que deve ser buscada por todos os tomadores de decisão, mormente os agentes públicos das respectivas áreas e, igualmente, da iniciativa privada, quando da interpretação das normas aplicáveis. Contudo, normalmente o que se percebe é não poder haver a harmonização do urbano e o natural, especialmente porque as cidades foram construídas e crescem sobre ambientes dantes originais e intocáveis. Esta é uma premissa que norteia a seguinte afirmação: onde há o homem há degradação e no espaço urbano é mais visível.

Neste diapasão, verifica-se que o elemento ativo é o urbano, onde há construções, obras e serviços que alteram, provisória ou definitivamente, o espaço natural, que pode ser considerado passivo por sofrer as investidas. É preciso, dessarte, envidar esforços no sentido de controlar este processo que pode, muito bem amparado por bases sólidas de ordem técnica, científica, tecnológica e legal, minimizar os impactos e nortear as melhores formas de compensação, restauração e proteção.

Conforme se verifica do relatório TEEB $(2010$, p. 81$)$, as cidades

[...] destroem recursos naturais como florestas, terras agrícolas, água e ar, para surtir as necessidades de consumo de seus habitantes, assim como para suprir as demandas de desenvolvimento de estrutura municipal, decisões de compra e prestação de serviços. De acordo com a OECD e IEA (2008), as cidades consomem globalmente $67 \%$ de energia e ao mesmo tempo emitem $70 \%$ dos gases do efeito estufa (Figura 4.1). Resíduos, poluição e emissões produzidos afetam não só as proximidades das cidades, mas também são transportados para outras regiões, causando impacto global.

Exemplo deste descompasso são as intervenções antrópicas em APP dos cursos d'água, ou seja, as construções às margens, tal como em topo de morro e restingas por todo o Brasil, com significativo prejuízo socioambiental, cultural e econômico.

É premente, dessarte, arregimentar meios científicos e especializados que viabilizem um maior entrosamento e compatibilidade relação entre o urbano e o ambiente natural, situação esta a depender quase que integralmente do poder público, até porque, de acordo com o TEEB (2010, p. 82), os "benefícios que as áreas urbanas obtêm dos ecossistemas estão diretamente ligados à gestão pública, através da qual as atividades e serviços municipais se tornam acessíveis".

O ponto de partida hermenêutico deve ser compreender o processo da ocupação espacial urbana e realizar de levantamentos e mapeamento dos passivos ambientais, 
destacadamente das APP's para permitir um diagnóstico apropriado do atual estado de preservação e degradação e estabelecer o prognóstico de como efetivamente envidar a imediata proteção dos remanescentes visando impedir o progresso dos passivos. Oliveira Júnior (2014, p. 108) anota que

O conhecimento dos problemas, então, só pode ter por ponto de partida a compreensão do que há no contexto urbano nas aludidas localidades e seus reflexos diretos e indiretos para a população, meio ambiente natural, Poder Público e economia. Feito isto, pode-se inventariar as APP's remanescentes nas áreas urbanas e efetivamente protegê-las de modo "permanente" e manter suas características originais, assim como auxiliar as políticas públicas que as incluam como espaços protegidos e norteie, compulsoriamente, quaisquer formas de ocupação nas imediações e área do entono.

Neste sentido, Menezes (2004, p. 24) realça o relevante papel da gestão ambiental urbana ser prioritariamente de "caráter antecipativa-preventiva" para haver um desejável "equacionamento do dilema desenvolvimento urbano/conservação do ecossistema urbano" capaz de sedimentar a salutar "internalização preventiva dos riscos envolvidos no agravamento da crise socioambiental". A mencionada gestão está, como não poderia deixar de ser, sob os auspícios do Município, como também o essencial controle da ocupação urbana

[...] não só para assegurar o ordenamento da cidade em seu conjunto, como para se certificar da segurança, da salubridade e da funcionalidade de cada edificação, individualmente considerada. [...] Além da aprovação do projeto, o controle das construções estende-se à execução da obra, possibilitando embargo e demolição quando realizada em desconformidade com o aprovado ou, antes de seu início, a cassação do alvará, se for o caso. (MEIRELLES, 2003, p. 542)

Castro (1996, p. 294), por seu turno, afirma caber ao Município o uso do poder de polícia administrativo no interesse geral e bem-estar da população devido as "ligações profundas com a segurança, a saúde, o sossego e o conforto das pessoas”. Idêntica postura se verifica com Medeiros (2007, p. 37, 62), para quem a proibição de construções é um dos “itens obrigatórios a ser observado no processo de planejamento urbano".

Outro imprescindível elemento para integralizar o processo hermenêutico é considerar os serviços ecossistêmicos que as APP's podem proporcionar. O relatório TEEB (2010, p. 6) consigna sua importância para formulação de política pública que ajude a reduzir custos futuros, tal como possa "alavancar as economias locais, melhorar a qualidade de vida e garantir a subsistência. Essa abordagem também ajuda a combater a pobreza, pois ela evidencia a distribuição dos recursos escassos e essenciais e também os serviços dos quais as pessoas dependem". 
As transformações exigíveis, a internalização destas premissas e a condizente compreensão das normas vigentes, por meio da hermenêutica, devem partir, principalmente, dos gestores municipais, cujo desafio, mencionado por Menezes (2014, p. 24)

[...] assume proporções preocupantes quando se constata um alto grau de dificuldade em reformularmos a atual governança ambiental urbana, que possibilite avançarmos da atual tendência de ações reativas/curativas para um nível de ações consequentes, visando a internalização preventiva dos riscos envolvidos no agravamento da crise socioambiental em nossas grandes cidades.

É difícil, mas não impossível, mudar os paradigmas equivocados do passado e do presente quanto a gestão do espaço urbano para fielmente poder atingir os mandamentos impostos pela Constituição de 1988 e Estatuto da Cidade. Surge, desse modo, mais uma vez, o planeamento como meio, formal, constitucional e infraconstitucional, mais apropriado para, no mínimo, reduzir as incertezas, dúvidas, impropriedades e problemas na megacomplexa relação entre o urbano e as APP's.

Assim, o planejamento municipal e percepção sobre as APP's existentes no cenário urbano é uma condição que não pode ser jamais negligenciada por ser ferramenta indispensável para o desenvolvimento e expansão urbana serem ordenadas, "permitindo uma ocupação dos espaços habitáveis de modo a garantir a convivência social em níveis que expressem a boa qualidade de vida" (ACKEL FILHO, 1992, p. 258). O Ministério do Meio Ambiente (MMA, 2018), ao tratar de cidades sustentáveis, reforça esta constatação.

O planejamento urbano-ambiental é um concreto direito coletivo para Fernandes (2006, p. 197) por "atender a uma função social e garantir a todas as pessoas o usufruto pleno da economia e da cultura e a utilização dos recursos e a realização de projetos e investimentos em seus benefícios" com propósitos de sustentabilidade ambiental. Sua existência é maior do que os gestores públicos e até mesmo do que a sociedade, por ser

[...] compulsório, ou seja, não fica, teoricamente, ao alvedrio ou caprichos dos governantes [...] Ora, se admitir que mesmo após o devido planejamento urbano fossem realizadas medidas outras nele não contempladas seria, por conclusão lógica, pertinente considerá-lo sem efeito ou até desnecessário. Só se planeja algo que, no caso urbanístico e levado a termo pelo Poder Público competente, deve ser executado sob pena de não se ter qualquer controle espacial do Município e de colocar a própria sorte a ocupação [...] com as piores consequências possíveis. (OLIVEIRA JÚNIOR, 2014, p. 103/104)

Seguindo este ideário, Bueno (2012, p. 110) propõe seja criada e disseminada a cultura do que considerou ser uma cidade compacta e sustentável, espaço no qual é "necessário proteger as áreas verdes em sentido amplo (produção agrícola, parques, clubes de campo, hotéis, sítios 
naturais, mananciais e áreas ecologicamente sensíveis)" e, naturalmente, inclui todas as formas de áreas de preservação permanente. Já Menezes (2014, p. 25) sugere a construção de uma cidade sustentável para o futuro "nos homens e não pelos homens", exatamente defronte uma nova mentalidade transformada e só assim "poderemos nos redimir da inconsequente relação agressiva que temos estabelecido com a natureza quando da ocupação dos espaços geográficos".

Todas as opções que podem surgir, mesmo pertinentes e abalizadas, não pode preterir a essencial participação da sociedade. Tal assertiva é reconhecida por Bueno (2012, p. 116) que orienta ser necessário para "cobrar do poder público municipal a qualificação da administração pública relacionada ao planejamento e gestão do território", medida esta que representaria a gestão municipal plena, até porque o futuro urbano é feito de "tendências e de vontade" que dependerão das políticas públicas (SANTOS, 2009, p. 139) a serem implementadas com respeito a todos os interesses envolvidos, até porque

[...] As cidades têm potencial para gerir recursos de uma maneira mais eficiente e ainda proteger os serviços ecossistêmicos. Deve-se desvincular o desenvolvimento urbano do consumo de recursos (menos espaço e energia para as habitações e transporte por pessoa). Por exemplo, o aumento de espaços "verdes" nas cidades aumenta a qualidade de vida e também contribui para o sequestro de carbono, mitigando, assim as mudanças climáticas. Muitas cidades têm uma alta concentração de biodiversidade e, frequentemente, a alta taxa de urbanização se sobrepõe a ecossistemas em perigo ou "hotspots" de conservação. (TEEB, 2010, p. 81)

Em face de todas estas considerações, é perceptível que a hermenêutica ambiental e urbanística possa, com a adequada interpretação das normas jurídicas aplicáveis, assegurar a proteção das áreas de preservação permanente por intermédio de pressupostos lógicos dedutivos aptos e condizentes para se promover a almejada sustentabilidade urbana.

\section{Conclusões}

O papel Áreas de Preservação Permanente (APP) existentes no ambiente urbano, afora a justificativa legal, tem por condão proporcionar melhores condições de vida, com qualidade, para todos no ambiente urbano. Sua preterição gera prejuízos incomensuráveis para as presentes e futuras gerações, o que deve ser cabalmente controlado pelo poder público, via das três esferas de governo, mas com destaque para o município que é quem deteve, constitucionalmente, a missão de promover um verdadeiro ordenamento urbano. 
Tal desiderato só poderá ser alcançado com o uso, tecnicamente qualificado, do planejamento e intervenção ativa da sociedade destinatária de toda e qualquer política pública urbano-ambiental, temas estes que jamais podem ser considerados como excludentes.

O direito a uma cidade sustentável não será efetivado sem a prévia predisposição do poder público em adotar os meios mais abalizados para viabilizar a correspondente coexistência e harmonia, esforço este essencial e que deve ser acompanhado pela coletividade.

A degradação ambiental nos espaços urbanos é uma realidade que merece ser enfrenada com responsabilidade, mormente quando está se tratando de proteger algo que simplesmente tem por função a preservação de tantos atributos geradores de serviços ambientais como os recursos hídricos, a paisagem, o solo, a estabilidade geológica, a biodiversidade e, sobretudo, “assegurar o bem-estar das populações humanas” (BRASIL, 2012, art. $3^{\circ}$, II).

A hermenêutica, assim, certamente acrescenta argumentos contundentes e pautados no ordenamento jurídico pátrio que subsidiem toda e qualquer tomada de providência em matéria ambiental e, notadamente, urbanística, tendo em mente o dever constitucional de garantir às presentes e futuras gerações um ambiente urbano com qualidade, o que só pode ocorrer com a tutela detida das áreas de preservação permanente.

\section{Referências bibliográficas}

ACKEL FILHO, Diomar. Município e prática municipal: à luz da Constituição Federal de 1988. São Paulo: Revista dos Tribunais, 1992.

ASSOCIAÇÃO BRASILEIRA DE NORMAS TÉCNICAS (ABNT). Disponível em: <www.abnt.org.br>. Acesso em: 15 fev. 2018.

AZEVEDO, Plauto Faraco de. Direito, Justiça Social e Neoliberalismo. São Paulo: Revista dos Tribunais, 1999.

BRASIL. Constituição da República Federativa do Brasil. Disponível em: $<$ http://www.lanalto.gov.br/ccivil_03/Constituicao/Constituiçao.htm>. Acesso em: 21 jan. 2017. 
BRASIL. Lei $n^{\circ}$ 6.938, de 31 de agosto de 1981. Dispõe sobre a Política Nacional do Meio Ambiente. Disponível em: <http://www.planalto.gov.br/ccivil_03/leis/L6938.htm>. Acesso em: 27 jan. 2017.

BRASIL. Lei no 10.257, de 10 de julho de 2001. Estatuto da Cidade. Disponível em: $<$ http://www.planalto.gov.br/Ccivil_03/leis/LEIS_2001/L10257.htm>. Acesso em: 15 fev. 2018 .

BRASIL. Lei n¹3.089, de 12 de janeiro de 2015. Estatuto da Metrópole. Disponível em: $<$ http://www.planalto.gov.br/ccivil_03/_ato2015-2018/2015/lei/113089.htm>. Acesso em: 15 fev. 2018.

BRASIL. Ministério das Cidades. Disponível em: $<$ http://www.cidades.gov.br/images/stories /ArquivosCidades/ArquivosPDF/Resolucoes/resoucao-34-2005_alterada.pdf $>$. Acesso em: 15 fev. 2018.

BRASIL. Ministério do Meio Ambiente. Disponível em: <http://www.mma.gov.br/cidadessustentaveis/planejamento-ambiental-urbano/instrumentos-de-planejamento $>$. Acesso em: 15 fev. 2018.

BRITO, Rosa Mendonça de. A hermenêutica e o processo de construção do conhecimento. Revista Eletrônica da Faculdade de Educação, vol. 1, n.3, 2007. Disponível em: $<$ http://dialoica.ufam.edu.br/PDF/no3/Rosa_Britto_Hermeneutica.pdf $>$. Acesso em: 22 fev. 2018.

BUENO, Laura Machado de Mello. Reflexões sobre o futuro da sustentabilidade urbana com base em um enfoque socioambiental. Cadernos Metrópole., [S.1.], n. 19, fev. 2012. ISSN 2236-9996. Disponível em: $<$ https://revistas.pucsp.br/index.php/metropole/article/view/8712>. Acesso em: 16 fev. 2018. doi:http://dx.doi.org/10.1590/8712.

CASTRO, José Nilo de. Direito Municipal Positivo. Belo Horizonte: Del Rey, 1996.

COSTA, Nelson Nery. Direito Municipal Brasileiro. Rio de Janeiro: Forense, 2012. 
FERNANDES, Edésio. A nova ordem jurídico-urbanística no Brasil. In: FERNANDES, Edésio; ALFONSIN, Betânia (Coord.). Direito urbanístico: Estudos brasileiros e internacionais. Belo Horizonte: Del Rey, 2006.

FERNANDES, Edésio. O desafio dos planos diretores municipais. In: FERNANDES, Edéio; ALFONSIN, Betânia (Coord.). Direito urbanístico: Estudos brasileiros e internacionais. Belo Horizonte: Del Rey, 2006.

FREITAS, Vladimir Passos de. A Constituição Federal e a Efetividade das Normas Ambientais. São Paulo: Revista dos Tribunais, 2005.

GABARDO, Marta Maria Bertan Sella. Metropolização, centralidades e periferias: Três cidades da região metropolitana de Curitiba. COSTA, Armando João Dalla; GRAF, Márcia Elis de (Orgs.). Estratégias de Desenvolvimento Urbano e Regional. Curitiba: Juruá, 2011. P. $45 / 62$

LIXA, Ivone Fernandes Morcilo. Hermenêutica Jurídica e Tradição Moderna: Limites, Impossibilidades e crítica latino americana. Grupo de Trabalho Hermenêutica, do XXII Congresso Nacional do Conselho Nacional de Pesquisa e Pós-graduação em Direito (CONPEDI). São Paulo, 2013. P. 207/223. Disponível em:

$<$ http://www.publicadireito.com.br/artigos/?cod=aa0f9de3c3f38177>. Acesso em: 22 fev. 2018.

MATOS, Eduardo Lima de. Autonomia Municipal e Meio Ambiente. Belo Horizonte: Del Rey, 2001.

MEIRELLES, Hely Lopes. Direito Municipal Brasileiro. São Paulo: Malheiros, 2003.

MEDEIROS, Edinaldo Aquino. A faixa de preservação permanente nas margens dos igarapés urbanos: uma análise da legislação e seus conflitos. In: ARGÛELLES, Francisco de Assis Aires (Coord.). Revista Jurídica do Ministério Público do Estado do Amazonas. Manaus: PGJ/CEAF, 2007. P. 37-62. 
MENEZES, Claudino Luiz. Estratégias de Desenvolvimento Urbano Sustentável no

Brasil: Tendências e perspectivas para o novo milênio. COSTA, Armando João Dalla;

GRAF, Márcia Elisa de (Orgs.). Estratégias de Desenvolvimento Urbano e Regional.

Curitiba: Juruá, 2004. P. 13/18.

MILARÉ, Édis. Direito do Ambiente. São Paulo: Revista dos Tribunais, 2009.

MUKAI, Toshio. Direito Urbanístico e Ambiental. São Paulo: Fórum, 2007.

NOVELINO, Marcelo. Direito Constitucional. São Paulo: Método, 2012.

OLIVEIRA JÚNIOR, Zedequias. Áreas de Preservação Permanente Urbana dos Cursos

D’Água: Responsabilidade do Poder Público e Ocupação Antrópica à Luz do Novo Código Florestal e seus Reflexos Jurídicos. Curitiba: Juruá, 2014.

OLIVEIRA, Regis Fernandes de. Comentários ao Estatuto da Cidade. São Paulo: Revista dos Tribunais, 2002.

OSÓRIO, Letícia Marques. Direito à Cidade como direito humano coletivo. In:

FERNANES, Edésio; ALFONSIN, Betânia (Coord.). Direito urbanístico: Estudos brasileiros e internacionais. Belo Horizonte: Del Rey, 2006.

PINTO, Victor Carvalho. Direito Urbanístico: Plano Diretor e Direito de Propriedade. São Paulo, 2011.

SANTOS, Milton. A Urbanização Brasileira. São Paulo: Editora da Universidade de São Paulo-Edusp, 2009.

SARNO, Daniela Campos Libório Di (Coord.). Direito urbanístico e ambiental. Belo Horizonte: Fórum, 2011.

SCHUSSEL, Zulma das G. L. A Evolução do Crescimento Urbano e a Preservação dos

Mananciais - Estudo de Caso: A região metropolitana de Curitiba. COSTA, Armando João 
Dalla; GRAF, Márcia Elisa de (Orgs.). Estratégias de Desenvolvimento Urbano e Regional. Curitiba: Juruá, 2011.

SILVA, José Afonso da. Direito Urbanístico Brasileiro. São Paulo: Malheiros, 2006.

STEFANI, Caroline Rossatto; CIGNACHI, Janaina Cristina Battistelo. Hermenêutica e os Direitos Fundamentais de Terceira Geração: Eficácia e aplicação da norma constitucional. Grupo de Trabalho Hermenêutica, do XXII Congresso Nacional do Conselho Nacional de Pesquisa e Pós-graduação em Direito (CONPEDI). São Paulo, 2013. P. 167/183. Disponível em: <http://www.publicadireito.com.br/artigos/?cod=aa0f9de3c3f38177>. Acesso em: 22 fev. 2018.

TEEB - A Economia dos Ecossistemas e da Biodiversidade para Formuladores de Políticas Locais e Regionais (2010).

TERENCE, Ana Cláudia Fernandes. Planejamento estratégico como ferramenta de competividade na pequena empresa: Desenvolvimento e avaliação de um roteiro prático para o processo de elaboração do planejamento. 2002. 238 f. Dissertação (Mestrado em Engenharia de Produção) - Universidade de São Paulo. São Paulo, 2002.

VICHI, Bruno de Souza. O direito urbanístico e as regras de competência na Constituição brasileira e no estatuto da cidade. In: DALLARI, Adílson Abreu; SARNO, Daniela Campos Libório Di (Coord.). Direito urbanístico e ambiental. Belo Horizonte: Fórum, 2011. 


\title{
OS NÚCLEOS URBANOS INFORMAIS CONSOLIDADOS COMO PRODUTO DA DUPLA CONTINGÊNCIA JURÍDICA NAS CIDADES BRASILEIRAS
}

\author{
Pedro Dias de Araújo Júnior \\ Universidade Federal de Sergipe
}

\begin{abstract}
Resumo
O presente artigo visa compreender os núcleos urbanos informais consolidados à luz da sociologia jurídica como um dos elementos de interpretação do novo marco legal de regularização fundiária. Com fundamento em Luhmann, o artigo analisa a dupla contingência de se viver em adensamentos urbanos paralegais e o direito à moradia. $\mathrm{O}$ artigo demonstra que os NUIC's podem ser compreendidos como autocatálise do direito de propriedade que partem de uma situação transitória irregular preservável para fins de regularização..
\end{abstract}

Palavras-chave: Núcleo Urbano Informal Consolidado, NUIC, Direito de Propriedade, REURB, Direito de Moradia.

\begin{abstract}
Resumen/Résumé
This article aims to understand the consolidated informal urban core, parallegal, in the light of law sociology as one of the elements of interpretation of the new legal framework of land tenure. Based on Luhmann, the article analyzes the double contingency of living in urban paralegal densities and the right to housing. The article demonstrates that the NUICs can be understood as an new autocatalysis of the property law that starts from an irregular transitory situation preservable for the purpose of regularization.
\end{abstract}

Keywords/Palabras-claves/Mots-clés: Parallegal Urban Core, NUIC, property law, REURB, housing rights. 


\section{Apresentação do tema}

Durante muito tempo, no Brasil o déficit de moradia da população carente foi combatido com a política de construção de novas residências patrocinadas pelo Poder Público. A cada governo, levas e levas de novos conjuntos habitacionais são feitos sem, contudo, conseguir se chegar ao menos próximo de um número que represente um déficit palatável de moradias.

No Brasil, o déficit habitacional da população menos assistida é estimado em cerca de 6,4 milhões de unidades, segundo dados do IBGE e realizados pela Fundação João Pinheiro em parceria com o Ministério do planejamento. Este déficit persiste mesmo após a entrega de cerca de 3,7 milhões de moradias pelo Governo Federal através do programa Minha Casa Minha Vida, ao custo estimado de 100 bilhões de reais. Segundo previsões, este déficit persistirá em função não apenas do crescimento populacional, como também é oriundo de novas famílias e o aumento da expectativa de vida (Editorial da Folha de São Paulo, página A2 da edição de 06 de maio de 2018).

Por outro lado, programas de habitação popular tradicionalmente possuem diversos equívocos, como a sua alocação longe dos centros urbanos - onde os empregos e serviços públicos essenciais estão localizados em sua maior grandeza - e muitas vezes também estão distantes de uma adequada infraestrutura de transporte público. A realidade dos programas termina por imprimir solução parcial mínima ao problema, posto que as moradias em locais distantes dos centros termina por criar outros problemas graves para o desenvolvimento sustentável daquela comunidade.

Sem ter outra opção, as populações menos favorecidas terminam por instituir suas moradias em locais dentro ou próximo dos grandes centros, mas em situações precárias tanto do ponto de vista ambiental quanto do urbanístico e jurídico.

Diante de uma quadro nefasto, seria natural o sistema político nacional olhar com outros olhos os núcleos urbanos informais consolidados, ora sendo representado pelas favelas, ora por um loteamento clandestino, ora por um próprio loteamento feito pelo poder público.

Muitas vezes, bairros inteiros foram construídos à margem do ordenamento jurídico civil. Em diversas cidades brasileiras - e a situação no cenário mundial não é diferente conjuntos habitacionais foram criados espontaneamente pela própria população, com ou sem auxílio público. Por vezes, o próprio conjunto já possui rede de coleta de esgotamento sanitário, fornecimento de água, energia, pavimentação e está próximo de serviços essenciais. O que lhe falta: juridicidade da ocupação. 
Ao se aplicar estritamente as normas do direito, o mais correto que se deveria fazer seria a remoção de famílias, demolição das estruturas já criadas e a reimplantação do conjunto habitacional em outra localidade, que deveria ser previamente desapropriada pelo Poder Público. Nesse ponto, surgem dois problemas de início: a existência de terrenos muito valorizados nas regiões centrais das cidades e o elevado custo de implantação desse novo assentamento.

$\mathrm{Na}$ prática, tal configuração jurídica significava a não implantação dos projetos públicos no quantitativo adequado à demanda da população.

Como forma de combater esse quadro nocivo, foi editada a Lei $13.465 / 17$, que trata da possibilidade de regularização fundiária - chamada REURB - destes assentamentos urbanos denominados Núcleo Urbano Informal Consolidado (NUIC), objeto central deste trabalho.

O nosso objetivo com o presente trabalho é trazer uma justificação à luz da sociologia do direito a ser aplicada nos NUICs. Ao compreender as razões pelas quais a legislação foi criada, instituindo-se um novo marco histórico no sistema de regularização fundiária brasileira, auxilia-se em sua interpretação.

A metodologia do presente trabalho é a pesquisa interdisciplinar entre o direito e a sociologia, através de pesquisa de livros relacionados ao tema.

\section{O meio ambiente urbano e a perturbação sistêmica}

\subsection{Action is System}

Em sua teoria de sistema social, Parsons desenvolveu a tese de que a ação é um dos elementos cruciais na análise dos sistemas. Ação e sistema não podem ser compreendidos separadamente ou, em outras palavras, a ação só é possível na forma de sistema. "A descoberta essencial foi a de que a construção de estruturas sociais se realiza sob a forma de sistema, e a operação basal sobre a qual esse sistema se constrói é a ação” (LUHMANN, 2009, p. 42).

Segundo sua teoria, a ação é uma propriedade emergente (emergente property) da realidade social; ou, em outras palavras, para que se realize uma ação, é preciso haver um número mínimo de componentes. Ao analisar os componentes, Parsons leciona que a ação é um processo no sistema de ator-situação que tem significado motivacional para o ator individual, ou, no caso de uma coletividade, seus componentes individuais. Age-se sempre por um motivo. Isto significa que a orientação do processo de ação tem a ver com: a) obtenção de bens 
(materiais ou imateriais); ou b) evitar privações para o ator relevante, qualquer que seja o caso concreto. O ator age para "obter" ou "evitar perder". Somente será tratada como ação do ator em sentido técnico na medida em que sua resposta à situação for analisada sob o cunho motivacional $^{1}$ (PARSONS, 2005, p. 3).

Na esteira do pensamento de Parsons, Luhmann leciona que a ação dos sistemas sociais é adotada, sobretudo, para situações importantes e emergentes:

Parsons entende essa análise sob a denominação de realismo analítico: realismo, no sentido de que, embora o esforço para decompor os elementos intrínsecos da ação constitua uma construção teórica conduzida pela sociologia, o resultado consistem em evidenciar que, graças a essa emergência, a ação brota. A referida construção deveria fazer jus às condições de possibilidades das ações e, nesse sentido, poder dar conta de todas as ações possíveis. E analítico, porque, ao identificar os componentes da ação, descobre-se que, tomados isoladamente, eles já não podem, por sua vez, continuar sendo designados sob a categoria da ação.

\title{
$[\ldots]$
}

A sociedade, antes que os indivíduos se disponham a agir, já está integrada pela moral, pelos valores e pelos símbolos normativos. Portanto, a sociedade não é possível, sem estar previamente integrada sob a forma de sistema. (LUHMANN, 2009, p. 42-43)

A obra de Parsons pode ser catalogada como variações infindáveis de uma fórmula relativamente simples e compacta que revela a quintessência de sua mensagem: action is system. (LUHMANN, 2009, p. 41). De fato, uma das essências de qualquer sistema é a sua mobilidade, sua constante ação e - por que não - sua constante interação, em especial nos sistemas tidos por abertos:

\begin{abstract}
Abertura significou comércio com o meio, tanto para a ordem biológica como para os sistemas voltados para o sentido (sistemas psíquicos, sistemas sociais...). Surgiu, assim uma nova ênfase no modelo: o intercâmbio. Para os sistemas orgânicos se pensa em intercâmbio de energia; para os sistemas de sentido, em intercâmbio de informação. Esses sistemas, por assim dizer, interpretam o mundo (sob o preceito da energia ou da informação) e reagem conforme esta interpretação. Em ambos os casos, a entropia faz com que os sistemas estabeleçam um processo de troca entre sistema e meio e, consequentemente, por sua vez, que esse intercâmbio suponha que os sistemas devam ser abertos (LUHMANN, 2009, p. 62).
\end{abstract}

Quer seja nos sistemas biológicos, quer seja nos sistemas físicos ou nos sistemas sociais, tudo está em contínuo movimento. As operações internas representam movimento. A

\footnotetext{
${ }^{1}$ No original: "Action is a process in the actor-situation system which has motivational significance to the individual actor, or, in the case of a collectivity, its component individuals. This means that the orientation of the corresponding action process has a bearing on the attainment of gratifications or the avoidance of deprivations of the relevant actor, whatever concretely in the light of the relevant personality strutcturs these may be. Only in so far as his reladon to the situation is in this sense motivationally relevant will it be treated in this work as action in a technical sense. It is presumed that the ultimate source of the energy or "effort" factor of action process is derived from the organism, and correspondingly that in some sense all gratification and deprivation have an organic significance. But though it is rooted in them the concrete organization of motivation cannot for purposes of action theory be analysed in terms of the organic needs of the organism. This organization of action elements is, for purposes of the theory of action, above all a function of the reladon of the actor to his situation and the history of that relation, in this sense of "experience".
} 
comunicação externa entre sistemas representa movimento. Daí o acerto da frase de Parsons que seria melhor traduzida para o português como "sistema é movimento".

\subsection{Forma sistêmica na teoria de Nicklas Luhman}

Uma das grandes questões quando se trata dos padrões jurídicos imobiliários no país é saber o que se é lícito ou ilícito, o que estaria dentro ou fora do conteúdo jurídico da legalidade. Como já mencionado, o Brasil - acompanhado de diversos outros países no mundo - possui um déficit habitacional gigantesco, o que termina por produzir perturbações sistêmicas no cerne do direito, em especial na configuração jurídica do direito de propriedade e sua função social. Mais precisamente, os movimentos sociais produzem irritações sistêmicas na periferia do direito, criando inputs de demandas para o sistema político decidir o que com eles fazer.

Estes movimentos sociais que atuam na periferia do direito - mas com fundamentos constitucionais (direito à moradia, função social da propriedade) - esbarram em um limite, que é exatamente o limite do ordenamento jurídico, mais precisamente no subsistema do direito imobiliário. Quais seriam então os limites do que se poderia chamar de subsistema do direito de propriedade brasileiro?

Para se compreender bem o conceito dos limites de um sistema, é necessário recorrer ao conceito prévio de forma. Uma forma delimita o sistema ou o subsistema. Luhmann recorre, então, à tese do matemático Spencer-Brow, para quem a forma "não está relacionada à estética (beleza ou feiura), mas significa um cálculo, uma operação. Forma é a operação de indicar e distinguir. Indicar significa, simultaneamente, distinguir, assim, como distinguir significa, simultaneamente, indicar" (GONÇALVES; VILLAS BÔAS FILHO, 2013, p. 44).

O próprio Luhmann, em ensaio sobre "signo como forma", traz considerações complementares à teoria de Spencer-Brow que auxilia na compreensão de forma para fins sistêmicos e, sobretudo, sociais. Os sistemas, pelo próprio fato de seu uso de operações internas, não pode deixar de estabelecer limites, pois é na sua parte interna que são realizadas as operações próprias através das quais os sistemas se reproduzem, se organizam e geram suas próprias estruturas e limites. De outro ângulo, qualquer sistema se constitui como uma forma, com um limite, com uma diferença assimétrica ente o sistema e o ambiente. E se um sistema tem à sua disposição as capacidades adequadas para reflexão, pode usar esta forma para 
significar, observar e descrever-se como diferente do ambiente (LUHMANN, 1999, p. 57)2 ${ }^{2}$. Os limites identificam as esferas de influência.

Conforme se observa, Luhmman é enfático ao afirmar que um dado sistema não pode operar sem seus limites (entendendo o limite como envergadura máxima de suas operações tidas como internas) e que um observador externo pode não enxergar com precisão os seus limites - embora este mesmo observador reconheça que a existência do limite é inquestionável. Isso não quer dizer, entretanto, que uma dada operação não possa eventualmente ultrapassar o limite do sistema: “[...] o conceito de limite significa que processos que ultrapassam os limites (p. ex., os processos de troca de energia ou de informação) são colocados sob outras condições de continuidade ao terem ultrapassado tais limites (p. ex, outras condições de valorização ou de consenso" (LUHMANN, 2016, p. 34). Ao perpassar os limites, a operação passa a ser trabalhada sob outras regras.

Ao se observar o histórico dos movimentos sociais que formaram os NUIC's, eles esbarravam nos limites do ordenamento jurídico, que não admitia a regularização fundiária de suas propriedades em boa parte das diversas hipóteses tratadas na nova norma. Sua destinação, até então, era permanecer no meio ambiente do sistema jurídico, após a periferia do sistema, sem conseguir obter juridicidade para as suas ocupações. Como limites existentes à época, podemos citar os loteamentos irregulares, as ocupações de décadas em imóveis públicos, ocupações em áreas de APP por população não necessariamente necessitada, dentre outros. Estes imóveis eram irregularizáveis. A nova legislação, ao tratar o NUIC como elemento de regularização, trouxe do meio ambiente um novo elemento importante para a dar juridicidade ao que já existe em praticamente todas as cidades brasileiras. Assim, o núcleo urbano informal consolidado (NUIC) passa a ser o novo limite do subsistema do direito imobiliário brasileiro.

\footnotetext{
${ }^{2}$ No original: "Now we have to consider yet another outside, namely, the outside of the difference between signifier and signified, that is, the outside of the unity of this difference, the outside of the sign. This would then be the world. Perhaps the theoretical need for closure forces us to follow this line of reasoning. Nonetheless, we must also keep in mind that, for a radical approach based on a theory of difference, the world concept cannot possibly the otherwise positioned. The "unmarked state" refers to a placeholder for what cannot be distinguished but can only be brought into a form by making a distinction. As a result, there are always further distinctions and other possible forms and significations. It does not follow from this that a sign-using, communicating system must - or even could - operate without boundaries. The world concept resolves this problem. For it is only the world that cannot be conceived in therms of boundaries or as a form; neither can it be conceptualized in tandem with anything on the other side of the boundary. Systems, by the very fact of their use of operations, cannot help but establish boundaries. Nonetheless, they reproduce themselves, organize themselves, and generate their own structures and boundaries by their own operations. Consequently, an observer outside the system could not detect the location of the system's boundaries, even thought their existence is unquestionable. Otherwise, no system could materialize. To state my position from another angle, any system constitutes itself as a form, as a boundary, as an asymmetrical difference between system and environment. And if a system has at its disposal the appropriate capacities for reflection, it can use this form (which, as we have shown, is the system itself) in order to signify, observe, and describe itself as different from the environment" (LUHMANN : 1999, p. 57).
} 


\subsection{O Sistema como Formador do Meio Ambiente}

Luhmann deixa claro que funda sua teoria sistêmica não na unidade, mas sim na diferença, quando afirma que o paradigma da teoria dos sistemas está assentado sobre uma diferença específica entre sistema e ambiente, que ele denomina de diferença diretriz (FRANKENBERG, 2007, p. 285). A diferença diretriz traça o limite sistêmico.

A distinção entre meio e forma remonta à teoria da percepção humana de Fritz Heider. Em interessante indagação - que influenciou Luhmann - Heider pergunta por que se atribui à causa de nossas percepções acústicas e visuais diretamente ao objeto percebido e não a nenhum dos muitos outros fatores que estão causalmente envolvidos em nossa percepção, que Heider classifica como o meio (ondas acústicas, ondas de luz). Heider explica isso com a diferença na constituição entre o objeto de percepção - a coisa - e outros fatores casuais - o meio. A diferença entre a coisa e o meio é conceituada como a diferença entre o acoplamento frouxo e apertado dos elementos. Devido ao acoplamento frouxo de seus elementos (isto é, sua abertura a uma multidão de conexões possíveis), o meio pode ser condicionado através da coisa. Em outras palavras, certos acoplamentos entre elementos no meio podem ser entendidos como reforçados através da coisa e, portanto, serem interpretados como "sinais" para a coisa (SEIDL, 2016, n.p.) ${ }^{3}$.

Nos seus escritos, Luhmann se inspira na ideia de Heider, mas a transforma em algo maior. Há a separação do conceito de sua referência ao mundo físico e, ao invés, passa a relacionar os conceitos de forma e meio ao observador. Forma passa a se referir a uma possível pré-seleção de conexões particulares observáveis dentre uma multitude de conexões possíveis.

\footnotetext{
${ }^{3}$ No original: "The distinction between medium and form goes back to Fritz Hider's theory of human perception (there, however, as a distinction between medium and thing). Heider asks why it is that we attribute the cause of our acoustic and visual perceptions directly to the perceived object, and not to any of the many other factors which are causally involved in our perception, such as light waves or air waves. He writes: 'Our perception points to one particular link of the [casual] chain. With regard to causality, all links of the chain are equal; with regard to perception they are not: there is, rather, one highlighted link, namely our object of perception'. Heider explains this with the difference in constitution between the object of perception - the thing - and the other causal factors - the medium. The difference between thing and medium is conceptualized as the difference between the loose and tight coupling of elements. Due to the loose coupling of its elements (that is to say, its openness to a multitude of possible connections), the medium can be conditioned through the thing. In other words, certain couplings between elements in the medium can be understood as enforced through the thing and hence be interpreted as 'signs' for the thing". (SEIDL : 2016, s/n)
} 
Essa possível conexão múltipla de formas ele dá o nome de meio. É importante entender o meio e a forma como conceitos relacionais: um meio é apenas um meio com relação à forma, mais precisamente a uma forma observada; portanto, o meio não é um mero espalhamento de elementos aleatoriamente. Para o meio, existe uma regra de criação, uma constante matemática, onde a parte mais importante é a identificação da forma (no caso da teoria de Luhmann, o sistema). O meio só pode ser observado como contingência de uma forma ${ }^{4}(\mathrm{SEIDL}, 2016$, n.p.).

O sistema constrói sua identidade à medida em que se distingue do ambiente. $\mathrm{O}$ ambiente, ao seu turno, reconhece-se como tal desde que o sistema seja o seu parâmetro de distinção. Desse paradoxo tem-se a primeira conclusão: o ambiente é um produto do sistema pela regra da diferença.

Um segundo elemento importante na teoria sistêmica de Luhmann é que tudo o que está fora do sistema é considerado ambiente. Logo, o observador interno de um dado sistema observará os demais sistemas também como meio ambiente, como entorno. Em síntese:

\begin{abstract}
Já sabemos que cada sistema se constitui a partir do estabelecimento de seus limites frente ao meio, que são limites de sentido. O sentido delimitador de cada sistema é exclusivo dele, pois um sentido comum a vários sistemas significa eliminar a diferença entre eles, fundi-los em um só. Daí que o mesmo sentido que serve para estabelecer que elementos pertencem ao sistema sirva também para determinar quais ficam fora dele, pertencendo, portanto, ao meio. O sentido permite a constituição do sistema a partir de uma disjunção elementar, que se repente constantemente: isto pertence ao sistema, isto não pertence.

$[\ldots]$

Cada sistema forma parte do meio dos outros sistemas. Isso quer dizer que cada sistema não percebe aos outros como sistemas, senão como aquela parte da complexidade que não se reduz com ajuste ao código e aos programas próprios (ARNAUD, 2004, p. 321-322).
\end{abstract}

Percebe-se, então, que o sistema possui uma forma (não materializada) e o que está fora dele é considerado meio. Forma e meio se autodefinem; por consequência, sistema e meio também se autodefinem. Tudo dependerá do olhar do observador; o sistema ao qual está sendo observado passa a irradiar os seus efeitos para o meio; a mudança de olhar para outro sistema transforma o sistema originalmente observado em meio do que está, agora, sendo analisado.

\footnotetext{
${ }^{4}$ No original em inglês: "It is important to understand medium and form as relational concepts: a medium is only a medium with regard to form, so it is not a pure scattering of elements. Equally, a for mis a form in a mediu; it is not a selection that is apparent in itself. This distinction, however, contais an asymmetry: the medium can only be observed from the perspective of possibilities for producing a form, not the other way around. In other words, it can only be observed as the contingency of the form and cannot be observed directly."
} 


\subsection{A Fórmula da Constante de Luhmann}

Um outro ponto não mencionado por Luhmann mas que consta das entrelinhas de sua tese é exatamente aquilo que não pode ser considerado um sistema. Para Luhmann, para que haja um sistema é preciso que se tenha uma abertura cognitiva e um fechamento operativo. No caso, há determinados fragmentos sociais que podem ter abertura cognitiva, mas que funcionam sem padrões operativos previamente definidos e, eventualmente, sem sancionamentos. É o caso, por exemplo, da corrupção sistêmica, que possuem padrões aleatórios de funcionamento e não podem ser considerados um sistema, mas sim como anomias ${ }^{5}$. Estes fragmentos inseridos na sociedade são chamados de resíduos.

Após a definição do sistema, passa-se agora a analisar o meio, também chamado de ambiente. O meio passa a ser formado também por vários outros sistemas e cada sistema terá o seu meio próprio e distinto dos demais, já que se opera uma exclusão do próprio sistema para a formação de seu meio. Junto aos demais sistemas há os resíduos, que não conseguem formar um sistema próprio 6 .

Logo, percebe-se que o meio pode, sim, ser expresso através de uma fórmula inspirada na matemática, de onde se tem os seguintes elementos:

- "So" seria qualquer sistema referenciado e objeto de estudo do observador. É o sistema observado;

- "M" seria meio ambiente, que está em constante mutação em função dos sistemas. $\mathrm{M}(\mathrm{So})$ seria o meio ambiente do sistema observado;

- $\quad \sum \mathrm{S}$ seria o somatório dos diferentes sistemas de uma sociedade;

\footnotetext{
${ }^{5}$ Utilizamos a anomia como um conceito mais próximo de Durkheim, compreendida como "ausência de normas", uma socialização imperfeita (GIDDENS : 1998, p. 163).

${ }^{6} 6$ Existem alguns autores que afirmam que nas favelas há um direito imobiliário paralelo, formado por normas próprias e com liderança institucionalizada. Boaventura de Souza Santos afirma que, no caso, há um pluralismo jurídico quando afirma que "Parto da verificação, hoje pacífica na sociologia do direito (e fundamentada em múltiplas investigações empíricas) de que, ao contrário do que pretendem a filosofia políticaliberal e aciência do direito que sobre ela se constitui, circulam na sociedade não uma, mas várias formas de direito ou modos de juridicidade. O direito oficial, estatal, que está nos códigos e é legislado pelo governo ou pelo parlamento, é apenas uma dessas formas, se bem que tendencialmente a mais importante. Essas diferentes formas variam quanto aos campos de ação social ou aos grupos sociais que regulam, quanto à sua durabilidade - que pode ir da longa duração da tradição imemorial até a efemeridade de um processo revolucionário - quanto ao modo como previnem os conflitos individuados ou sociais e como os resolvem sempre que ocorrem, quanto aos mecanismos de reprodução da legalidade, e distribuição ou sonegação do conhecimento jurídico. Parto, assim, da ideia da pluralidade das ordens jurídicas, ou de forma mais sintética e corrente, do pluralismo jurídico" SANTOS, 1988, p. 60). Entretanto, essa ordem paralegal não poderia ser considera um sistema na teoria de Luhmann porque entre um conflito entre juridicidades - a legal e a paralegal - as soluções e os códigos a serem aplicados são a do sistema legal. Assim, ocorreria o que Luhmann chama de corrupção sistêmica no sistema paralegal, fazendo com que o mesmo opere sob os códigos de outro sistema de uma forma tão acentuada que lhe retiraria autonomia. Portanto, sua conceituação estará mais adequada como sendo resíduo e não sistema.
} 
- "R" seriam os resíduos ambientais, compostos por segmentos sociais que (ainda) não são considerados sistemas por não terem fechamentos operativos. São as anomias.

A conjugação e ordenação de todos esses fatores terminam por representar o pensamento de Luhmann através de uma equação, que é a fórmula da constante de Luhmann: $\mathrm{M}(\mathrm{So})=\sum \mathrm{S}+\mathrm{R}-$ So. Ou seja, o meio ambiente do sistema observado é o somatório de todos os sistemas sociais mais o resíduo, excluindo-se o próprio sistema observado. Através da fórmula constante $\sum \mathrm{S}+\mathrm{R}-\mathrm{So}$, percebe-se que o meio ambiente pode ser conceituado como um "vir a ser"; ele virará o meio ambiente de um dado sistema. O sistema formata seu meio ambiente, que sofrerá tantas mutações a depender de quantos sistemas existirem e essas mutações ocorrerão quando o olhar do observador saltar de um sistema a outro. Esta ação do vir-a-ser corresponde à efetuação de uma diferenciação feita exclusivamente pelo sistema, pois essa diferenciação do meio ambiente é o resultado de uma operação concomitante com a criação de um sistema.

Como o meio passa a operar então? Ele teria regras próprias, seria também um outro sistema? Como ele se diferencia? Teria limites a serem mantidos (boundary maintenance) como os sistemas? Ao responder a essas indagações, Luhmann explica:

É mediante o sistema e somente e relação ao sistema que o ambiente obtém sua unidade. Ele é demarcado por horizontes abertos, e não por limites ultrapassáveis; ou seja, ele mesmo não é um sistema. Ele é diferente para cada sistema, já que cada sistema exclui somente a si mesmo de seu ambiente. De modo que não há autorreflexões do ambiente e muito menos capacidade de ação. A atribuição ao ambiente ("atribuição externa"), por seu lado, é uma estratégia sistêmica. Tudo isso, porém, não significa que o ambiente dependa do sistema ou que o sistema possa dispor à vontade de seu ambiente. Pelo contrário, a complexidade do sistema e do ambiente - voltaremos a esse tema - exclui toda forma totalizante de dependência em qualquer direção. (LUHMMAN, 2016, p. 34).

O meio não é significativo apenas para a manutenção do sistema, para o seu reabastecimento de energia e informação. Para a teoria de Luhmann, o ambiente é pressuposto da identidade do sistema, porque a identidade só resta possível mediante a diferença (um determinado objeto só tem identidade se for distinto de outro; caso contrário, pode-se falar em réplicas e o conceito de identidade é transladado para o grupo de objetos idênticos).

Assim, todas as operações que ocorrem dentro de um dado sistema passam a serem vistas por dois pontos de observação: tudo o que acontece é sempre ao mesmo tempo pertencente a um sistema e pertencente ao ambiente de outros sistemas. Cada alteração em um dado sistema é alteração em uma parte do ambiente de outro sistema. Por isso, o ambiente (meio) é sempre muito mais complexo do que o próprio sistema. 


\section{5 - A Constante Perturbação Sistêmica para a Busca da Estabilidade e a Falsa Noção do Equilíbrio}

O objetivo do subsistema do direito imobiliário é estar em equilíbrio? Se assim o fosse, como se trataria os NUIC's antes do novo marco regulatório? A legislação antiga tinha capacidade de produzir equilíbrio em face das perturbações (irritações) sistêmicas? Um dos primeiros modelos da teoria dos sistemas é o orientado pela metáfora do equilíbrio, cujo termo já era empregado no século XVII no conceito de balance of trade (equilíbrio do mercado internacional), cuja teoria defendia a política econômica de um determinado país deveria ser acumular materiais essenciais (ouro, prata) para se fortalecer economicamente através do sistema de exportações/importações. Na economia, esta busca por um equilíbrio já vinha sendo criticada há séculos por economistas de escol como Adam Smith7.

No caso das demais ciências, entretanto, a noção de "equilíbrio sistêmico" passou a ganhar corpo, ao ponto de Luhmann, inspirado na crítica de Easton, a chamar de uma grande metáfora:

[...] a metáfora alude a um estado de fragilidade, na medida em que qualquer perturbação - se imaginada numa balança - conduz ao desequilíbrio. Esse desenho desenvolve, assim, uma grande sensibilidade face às perturbações e leva a resultados que buscam privilegiar o equilíbrio. $\mathrm{O}$ modelo não é propriamente uma teoria, mas a manifestação de um estado específico, que permite perceber claramente a relação entre estabilidade e perturbação.

$\mathrm{Na}$ tradição do pensamento sociológico, conferiu-se ao equilíbrio uma alta valorização, enquanto teorias baseadas na noção de perturbação foram evitadas. Isso é válido, principalmente, para a teoria econômica, ou as teorias que enfatizam o equilíbrio entre os distintos fatores (LUHMANN, 2011, p. 60-61).

\footnotetext{
${ }^{7}$ Esta específica teoria do equilíbrio de mercado já era duramente criticada por Adam Smith antes dos aspectos gerais da teoria do equilíbrio ser criticada, também, pelas ciências sociais: "Smith believes the identification between wealth and money leads to the special concern that authors of the commercial system place on the balance of trade. The balance of trade is the only way for a country with no mines to accumulate gold and silver and therefor 'it necessarily became the great object of political economy to diminish as much as possible the importation of foreign goods for home-consumption, and to increase as much as possible the exportation of the produce of domestic industry. Smith considers there is nothing 'more absurd' than this doctrine as the foundation of all the regulations of commerce. Economic policy, according to Simth, passes from one useless concern, the ban of metal exports, to another even more useless and more complex, the regulation of imports and exports. This means abandoning internal trade, the 'trade in which equal capital affords the greatest revenue, and creates the greatest employment. The doctrine of the balance of trade leads to a misallocation of resources.

This particular concern for foreign trade reveals the partial character of theses policies because those who promoted them 'did not really know how foreign trade enriched the coutry', they only knew it enriched themselves. The tenants of this vies do not realize, according to Smith, that free trade is always advantageous. The benefit of commerce, says Smith, is not bringing money into the country, but promoting industry, manufactures and opulence" (PRIETO : 2006, p. 227)
} 
Com muita propriedade, Luhmann destaca que o "equilíbrio" não chega a ser uma teoria, mas sim um determinado "estado". O grande pecado de seus teóricos seria imaginar que os sistemas estariam em um constante equilíbrio, sofrendo poucas perturbações e, por esta razão, os estudos sobre as perturbações/irritações sistêmicas tivessem sido relegados a segundo plano. Em outras palavras, o equívoco segundo Luhmann estaria no foco do equilíbrio como elemento de primeira importância ao invés de foco nas perturbações sistêmicas. Tal ideia também é compartilhada por Jean Clam quando afirma que "sistemas são intrinsecamente instáveis" (CLAM, 2006, p. 149). Inclusive, Luhmann é muito claro ao afirmar que "há sistemas que não estão em equilíbrio, mas são estáveis (ou podem sê-lo)" (LUHMANN, 2013, p. 137).

De fato, é no desequilíbrio que os sistemas chegam à sua estabilidade ${ }^{8}$. Nesse ponto, a imagem de um sistema é muito parecida com a de um avião em rota de voo. Ele irá passar por diversas perturbações - praticamente inevitáveis por todo o voo (correntes de ar, baixas temperaturas, turbulências, desvios não programados) - e o que define o sucesso de seu voo são as operações internas, os desequilíbrios provocados para a alteração do traçado retilíneo, enfim, é o enfrentamento das diversas perturbações que ocorrerão em todo o trajeto. Em juízo análogo, a engenharia aeronáutica foca no equilíbrio da aeronave ou presta atenção nas previsíveis perturbações que o sistema da aeronave possa ter durante o voo? O equilíbrio é uma consequência do estudo e enfrentamento das perturbações? Ao adaptar essas perguntas para as demais ciências, percebe-se que o equilíbrio nada mais é do que um determinado estado atingido a despeito de todas as perturbações sofridas.

\footnotetext{
${ }^{8}$ David Easton, analisando a teoria do equilíbrio na ciência política, afirma que alguns sistemas políticos podem apostar no desequilíbrio para se manterem no poder, o que retira a noção de equilíbrio como uma norma maior a ser perseguida: "Numerosas dificuldades conceituais e empíricas colocam-se no caminho da utilização efetiva da ideia de equilíbrio na análise da vida política. Entre elas existem duas particularmente importantes aos objetivos presentes. Em primeiro lugar, a abordagem de equilíbrio dá a impressão de que os membros de um sistema têm apenas uma finalidade básica quando procuram lidar com a mudança ou distúrbios: restabelecer o antigo ponto de equilíbrio ou mudar para um novo. Isso é habitualmente chamado, pelo menos implicitamente, de procura da estabilidade, como se acima de tudo se buscasse a estabilidade. Em segundo lugar, pouca ou nenhuma atenção é explicitamente dada à formulação de problemas relacionados ao caminho que toma o sistema na busca do retorno ao suposto ponto de equilíbrio antigo, ou à obtenção de um novo ponto. É como se os caminhos tomados para a manipulação dos deslocamentos fossem uma consideração teórica mais incidental do que central. É, porém, impossível compreender os processos subjacentes à capacidade de qualquer espécie de vida política de sustentarse numa sociedade, se os objetivos ou a forma das respostas são tomados como fato consumado. Um sistema pode perfeitamente ter outras finalidades que não a de alcançar um ou outro ponto de equilíbrio. Muito embora a ideia de um estado de equilíbrio devesse ser usada apenas como norma teórica que não é adquirida, tal concepção ofereceria uma aproximação teórica da realidade bem menos útil que outra que levassem conta outras possibilidades. Seria de maior auxílio conceber uma abordagem conceitual que reconhecesse que os membros de um sistema podem, ocasionalmente, querer agir de forma positiva para a destruição de um equilíbrio anterior, ou mesmo obter qualquer novo ponto de desequilíbrio contínuo. Este é o caso típico das autoridade que procuram manter-se no poder criando tumulto interno ou perigos externos. (EASTON, 1970, p. 188-189).
} 
O mesmo se dá com os sistemas. O constante foco nas forças que podem desestabilizar um dado sistema é o primeiro e mais importante objeto de estudo:

A perturbação chega a sugerir, inclusive, uma perspectiva de potencialização do sistema, na medida em que este pode ficar permanentemente exposto às alterações e continuar sendo estável. De qualquer modo, essa compreensão da estabilidade a partir do desequilíbrio se dissocia da tradição conceitual que tratou o desequilíbrio na direção do binômio estabilidade/perturbação.

O modelo do desequilíbrio possibilitou que se vislumbrasse uma teoria geral dos sistemas. (LUHMANN, 2011, p.61)

Os NUICs representam, em verdade, o novo foco da perturbação sistêmica. Se contarmos que $36,6 \%$ da população brasileira vive em favelas (quase todas conceituadas como NUIC), envolvendo cerca de 51 milhões de habitantes, temos uma ideia do tamanho do trabalho de regularização a ser feito (DAVIS, 2006, p. 34). Apesar da nova legislação, os NUIC's continuam à margem da lei - podendo ser regularizados e inseridos no sistema de proteção legal tradicional. Ao invés de focar puramente no equilíbrio - protegendo as propriedades em uma forma tradicional - o ordenamento passou a identificar os NUICs como elementos de transição, como perturbações sistêmicas que merecem a atenção do sistema jurídico.

\section{Os NUICs como produto de dupla contingência jurídica}

\section{1 - O que vem a ser o Núcleo Urbano Informal Consolidado}

Apesar de termos uma noção de que existem milhares de favelas no Brasil nas grandes metrópoles como São Paulo, Rio de Janeiro, Salvador, Recife e Belo Horizonte, dentre outras, o fenômeno dos assentamentos irregulares não é exclusivo do Brasil. De acordo com Mike Davis,

Pode haver mais de 250 mil favelas na Terra. Sozinhas, as cinco maiores metrópoles do sul da Ásia (Karachi, Mumbai, Déli, Kolkata e Daca) somam cerca de 15 mil comunidades faveladas diferentes, com um total de mais de 20 milhões de habitantes. Uma população favelada ainda maior cobre o litoral em urbanização da África ocidental, enquanto outras conurbações imensas de pobreza espalham-se pela Anatólia e pelas terras altas da Etiópia; abraçam a base dos Andes e do Himalaia; explodem para longe dos núcleos de arranha-céus da Cidade do México, de Jo-Burg (Joanesburgo), Manila e São Paulo; e, claro, ladeiam as margens dos rios Amazonas, Níger, Congo, Nilo, Tigre, Ganges, Irrawaddy e Mekong. [...]

Desde 1970, o crescimento das favelas em todo o hemisfério sul ultrapassou a urbanização propriamente dita. Assim, examinando a Cidade do México do final do século XX, a urbanista Priscilla Connolly observa que "até $60 \%$ do crescimento da 
cidade resulta de pessoas, principalmente mulheres, que constroem heroicamente suas próprias moradias em terrenos periféricos sem uso, enquanto o trabalho informal de subsistência sempre foi responsável por grande proporção do total de empregos". As favelas de São Paulo - meros 1,2\% da população em 1973, mas 19,8\% em 1993 cresceram na déca de 1990 no ritmo explosivo de 16,4\% ao ano. Na Amazônia, uma das fronteiras urbanas que crescem com mais velocidade em todo o mundo, $80 \%$ do crescimento das cidades tem-se dado nas favelas, privadas, em sua maior parte, de serviços públicos e transporte municipal, tornando assim sinônimos "urbanização" e "favelização". As mesmas tendências são visíveis em toda a Ásia (DAVIS, 2006, p. 27).

Conforme o artigo 11 da Lei 13.465/17 deixa muito claro e no esteio de fomentar o acesso à propriedade, o foco principal de trabalho da REURB são os núcleos urbanos informais consolidados que possuem as seguintes características:

a) são assentamentos humanos com uso e características urbanas, cuja área é inferior ao módulo rural;

b) é assentamento clandestino, irregular ou que, por qualquer motivo, não foi possível realizar a titularização de seus ocupantes. Logo, independe de terem estado, ab initio, de boa ou má-fé; c) é de difícil reversão, considerados o tempo da ocupação, natureza das edificações, localização das vias de circulação e a presença de equipamentos públicos.

Como se observa, o núcleo urbano informal consolidado (NUIC) representa a imensa maioria dos casos onde não se conseguia, anteriormente e com base nas legislações passadas, regularizar o imóvel. O ocupante de um imóvel em um NUIC, ao seu turno, é definido como “aquele que mantém poder de fato sobre lote ou fração ideal de terras públicas ou privadas em núcleos urbanos informais" (Art. 11, VIII, da Lei 13.465/17).

Um núcleo urbano informal consolidado (NUIC) corresponde a uma transitoriedade permanentemente articulada ao estigma territorial de uma ocupação à margem da lei. Constituem zonas de indeterminação entre o lícito/ilícito, ter/não ter, planejado/não planejado, formal/informal, dentro/fora do mercado, presença/ausência do Estado e, na maioria das vezes, inclusão/exclusão social; enfim, é formado basicamente na tensão entre códigos binários. Atualmente, pode ser considerado um núcleo urbano na fronteira do legal e do ilegal com inegáveis consequências sociais. Nas palavras de Vera Telles,

Nas suas configurações contemporâneas, práticas e situações instauradas no centro da vida política (e da normalidade democrática) fazem estender uma zona de indeterminação entre a lei e a não lei, terrenos de fronteiras incertas e sempre deslocantes nos quais todos e qualquer um se transformam em vida matável, homo sacer (TELLES, 2010, p. 29).

Em muitos desses NUICs, o "crime" em questão dos ocupantes "é não obedecer ao planejamento, locus onde se definem as formas permitidas - ou proibidas - de organizar o espaço" (ROLNIK, 2015, p. 174). 


\title{
3.2 A dupla contingência jurídica
}

Nas palavras de Luhman, “sem noise não há sistema” (LUHMANN, 2016, p. 140). Os problemas são, faticamente, catalizadores eficazes da vida e das mudanças sociais. Estes problemas não são escolhidos ao acaso; mediante seleção, a realidade reage a problemas que nela se colocam. O tempo, por exemplo, pode ser um critério de seleção: ele continuamente equilibra irreversibilidades e reversibilidades.

No caso dos NUICs, eles são realidades sociais até então despidas de densidade jurídica protetiva. Não havia como buscar solução exclusivamente no consenso já existente, ou seja, exclusivamente na dimensão social, eis que a problemática dos NUICs eram não só sociais, mas também políticas e, sobretudo, jurídicas.

O que se tinha no caso dos NUICs era o que Luhmann chama de duas black boxes (LUHMANN, 2016, p. 132). De um lado, os proprietários de terra que, a despeito até mesmo de ter estimulado a irregularidade em suas terras (como no caso em que há um loteamento irregular feito pelo próprio proprietário), não dialogam com o sistema jurídico para a correção do problema. De outro, os ocupantes irregulares dos terrenos, vivendo à margem da lei, com possibilidade de serem reintegrados em diversas situações (como no caso de ocupações de terrenos públicos).

Nessa temática, Raquel Rolnik assevera:

\begin{abstract}
Ao tratar dos assentamentos populares das cidades ao redor do mundo, a categoria "ilegal" não deve - e não pode - ser absolutizada. Em vários casos, a maioria dos habitantes vive em sistemas de posse que podem ser considerados paralegais, semilegais ou quase legais, tolerados ou legitimados por leis costumeiras ou pelo simples uso ou tradição, reconhecidos ou simplesmente ignorados pelas autoridades (ROLNIK, 2015, p., 175).
\end{abstract}

A realidade social e a realidade jurídica representavam duas contingências na apreciação do problema, que teriam que ser resolvidas pelo subsistema jurídico. Aqui, tem-se a formação do ego e do alter, sendo que os mínimos existenciais de cada um é denominado de black box. Cada uma dessas caixas determina o seu próprio comportamento mediante operações autorreferenciais complexas no interior de seus limites. Na visão de Luhmann,

Aquilo que dela se torna visível é, por isso, necessariamente uma redução. Cada uma supõe o mesmo da outra. Por isso, mesmo com todo o esforço e todo o emprego de tempo (elas próprias são sempre mais rápidas!), as duas black boxes permanecem opacasa uma para a outra. Ainda que operem estritamente de modo mecâncio, elas tem de supor indeterminabilidade e determinabilidade na relação de uma com a outra. 
As caixas pretas produzem, por assim dizer, brancura quando uma encontra a outra, ou pelomenos encontram transparência suficiente para o tratamento mútuo. Mediante suas simples suposições, elas produzem certeza de realidade porque esse supor conduz a um supor do supor na relação entre alter e ego. A assimilação de materiais de sentido nesse nível dordem pressupõe dois sistemas autorreferenciais que se observam reciprocamente - já havíamos falado acima de constituição "muualista". Para os poucos aspectos que contam em sua relação, sua capacidade de processamento de informação pode ser suficiente. Eles permanecem separados, não se fundem, não se entendem melhor do que antes; eles concentram-se naquilo que podem observar no outro como um sistema-em-um-ambiente, como input e outpu, e em suas próprias perspectivas de observador aprendem respectivamente de modo autorreferencial. Eles podem tentar influenciar mediante seu próprio agir aquilo que eles observam, e podem, então, aprender com ofeedback. (LUHMANN 2016, p. 132-133).

Assim, no contexto da dupla contingência, expectativas adquirem valor estrutural e estruturante para a construção de subsistemas jurídicos emergentes em uma autêntica situação de output, construindo assim um tipo próprio de realidade ${ }^{9}$. Enquanto que o subsistema dos NUIC's, enquanto subsistema social (e não jurídico) criava seus próprios outputs, o subsistema jurídico não tinha uma resposta satisfatória a lhe dar para a maioria de sua problemática.

Tomando como exemplo o caso dos imóveis públicos ocupados por população de baixa renda, tem-se de um lado a tolerância do Poder Público para com os movimentos sociais que invadem o imóvel, muitas vezes movidos por questões políticas. Muitas vezes, é o próprio Poder Público que termina fazendo obras de urbanização em ocupações irregulares, gerando uma certa transparência comunicativa entre o invasor e o Poder Público, todos à margem da lei. A transparência relativa obtida por este modo tem seu preço pago com a experiência da contingência. O conhecimento e o cálculo do comportamento do outro são substituídos pela concessão de liberdade de agir, concluindo-se que há uma redução do parâmetro legal fixada no vivenciar pela ação dos agentes, guiada pela concessão de liberdade, pelo estímulo à permanência.

Essa dupla contingência do tensionamento do lícito/ilícito permanente é bem anisada por Luhmann quando afirma, litteris:

Uma consequência importante diz respeito à questão sobre o domínio de que diferença
começa a funcionar um sistema construído com base na dupla contingência. No
contexto do individualismo moderno e da Teoria da Ação, é fácil supor que se deva
partir aqui do proveito próprio do agente ou de seus objetivos (seja como forem
colocados: subjetivamente, irracionalmente, desinformadamente ou
equivocadamente). Mas o teorema da dupla contingência conduz a outro resultado. O
sistema é colocado em funcionamento e se orienta primeiramente pela questão sobre
se o interlocutor aceitará ou recursará uma comunicação, ou, se reduzirmos à ação: se
uma ação lhe será útil ou prejudicial. A posição do interesse próprio resulta, apenas

\footnotetext{
${ }^{9}$ Outputs são as decisões e ações das autoridades. Os outputs não apenas ajudam a influenciar os acontecimentos na sociedade mais ampla, da qual o sistema é uma parte, como também, ao fazer isso, "auxiliam a determinar cada grupo de inputs que se sucedem em direção ao sistema político.” (EASTON, 1970, p. 196). Como output político/jurídico, podemos indicar as normas jurídicas produzidas pelo sistema, como constituições, leis ordinárias, medidas provisórias, dentre outras.
} 
secundariamente, do modo como o interlocutor reage a uma sugestão de sentido. Perseguir o interesse próprio é um posicionamento por demais pretensioso para que possa ser uma pressuposição geral (e as respectivas teorias são também teorias desenvolvidas muito tardiamente). Por outro lado, nenhum sistema social começaria a funcionar se aquele que inicia a comunicação não pudesse saber ou não se interessasse em saber se seu interlocutor reage negativa ou positivamente ao que ele está comunicando. Mesmo que esse contato não fosse interrompido imediatamente, uma situação assim totalmente indeterminada desencadearia inicialmente esforços para esclarecer as pressuposições da diferença relacionada ao interlocutor (LUHMANN, 2016, p. 140).

O mesmo standard pode ser aplicado às relações sociais ínsitas aos NUICs, pois essa dupla contingência produz pressão para a ação. Essa pressão pode ser mencionada pela criação da Lei 13.465/17, que tratou especificamente do novo sistema de regularização fundiária partindo da base dos NUIC's.

Ao tratar os NUIC's como o objeto a ser regularizado via REURB, a regularização fundiária permanece primeiramente dependente dos problemas de habitação irregular que têm de ser tratados urgentemente na remodelação do sistema da sociedade de uma ordem irregular para um sistema funcionalmente diferenciado e levados a novas formas semânticas no direito imobiliário. A REURB nos NUIC's torna provável o que até então era improvável: a titulação dos ocupantes irregulares, até mesmo se o imóvel for público e de usucapião impossível. Para Luhmann:

\begin{abstract}
Essa concepção é desenvolvida com a radicalização do problema da dupla contingência. Ela articula a questão "como a ordem social é possível” de um modo que essa possibilidade se apresenta primeiramente como improvável. [...] além da improbabilidade da ordem social, essa concepção também esclarece a normalidade dessa ordem; pois, sob essa condição de dupla contingência, cada autodeterminação, tenha ela surgido acidental ou calculadamente, adquire valor informativo e conectivo para o agir do outro. [...] Em um primeiro momento pode surpreender que a duplicação da improbabilidade (relacionada a cada escolha específica de comportamento) conduza à probabilidade. Não se trata de um simples problema linear de multiplicação ou diminuição. Se de maneira complementar a própria insegurança comportamental, a escolha comportamental do outro também é insegura e depende conjuntamente de seu próprio comportamento, surge a possibilidade de se orientar justamente por isso e, em relação a isso, determinar o próprio comportamento. É, portanto, a emergência de um sistema social que se torna possível mediante a duplicação da improbabilidade, facilitando a determinação de cada comportamento próprio. (LUHMANN, 2016, p. 140).
\end{abstract}

\title{
4. Conclusões
}

A experiência da dupla contingência possibilita e constrange a uma ultraperspectiva que dá às sequencias comportamentais novos limites dentro do ordenamento jurídico, após as irritações sistêmicas produzirem outputs legislativos no subsistema jurídico brasileiro.

O NUIC é o mais importante output da história jurídica brasileira em tema de regularização fundiária, introduzido pela Lei 13.465/17. 
A dupla contingência no caso dos NUIC's teve qualidades de um fator autocatalítico: sem se tornar consumido pelo problema, as duas situações improváveis (ocupações irregulares e direito dos proprietários) se fundiram e possibilitaram a construção de estruturas num novo nível de ordenação que veio a ser regulada pelas perspectivas constitucionais (direito de propriedade e função social da propriedade). É, sobretudo, uma autocatálise porque ele mesmo parte do sistema que se forma.

Assim, a experiência da contingência realizou a constituição e a viabilização dos acasos das ocupações irregulares (e, a fortiori, das urbanizações espontâneas) em probabilidades de uma construção estrutural do direito de propriedade.

Por fim, os NUIC's podem ser compreendidos como autocatálise do direito de propriedade que partem de uma situação transitória irregular preservável para fins de regularização.

\section{Referências bibliográficas}

ARNAULD, André-Jean; DULCE, M.J.F. Introdução à análise sociológica dos sistemas jurídicos. Rio de Janeiro : Renovar, 2000.

DAVIS, Mike. Planeta Favela. São Paulo : Boitempo, 2006.

EASTON, David. Modalidades de análise política. Rio de Janeiro : Zahar Editores, 1970.

GONÇALVES, Guilherme Leite; VILLAS BÔAS FILHO, Orlando. Teoria dos sistemas sociais. Direito e sociedade na obra de Niklas Luhmann. São Paulo : Saraiva, 2013.

LUHMANN, Niklas. Introdução à teoria dos sistemas. $3^{\text {a }}$ edição. Petrópolis : Editora Vozes, 2011.

. Sign as form in Problems of form. Edited by Dirk Baecker, translatad by Micahel Irmscher with Leah Edwards. Stanford : Stanford University Press, 1999.

Sistemas sociais. Esboço de uma teoria geral. Petrópoles : Editora Vozes, 2016. 
PARSONS, Talcott. The Social System. London :Taylor \& Francis e-Library, 2005.

PRIETO, Jimena Hurtado. Adam Smith, mercantilism, and Mandeville. In New Voices of Adam Smith, edited by Leonidas Montes and Eirc Schliesser. New York, Routledge, 2006.

ROLNIK, Raquel. Guerra dos Lugares. São Paulo : Boitempo, 2015.

SANTOS, Boaventura de Sousa. Uma cartografia simbólica das representações sociais. Revista Crítica de Ciências Sociais, nº 24. Coimbra : Editora Centro de Estudos Sociais, 1988.

SEIDL, David. Organisational identity and self-transformation. New York : Routledge, 2016.

TELLES, Vera da Silva. As cidades na fronteira do legal e do ilegal. Belo Horizonte : Argvmentvm, 2010. 


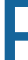

Este livro reúne artigos científicos apresentados e debatidos nos Grupos de Trabalho: "DIREITO ADMINISTRATIVO E GESTÃO PÚBLICA" e "DIREITO URBANÍSTICO, CIDADE E ALTERIDADE" no decorrer do VIII Encontro Internacional do CONPEDI (Conselho Nacional de Pesquisa e Pós-Graduação em Direito - Brasil), realizado entre os dias 06 e 08 de setembro de 2018 na cidade de Zaragoza - Espanha. 